UNIVERSIDADE DE SÃO PAULO

FACULDADE DE ARQUITETURA E URBANISMO

EIA-RIMA INSUFICIENTE COMO AVALIAÇÃO DE IMPACTOS AMBIENTAIS ENQUANTO BUSCA DE SUSTENTABILIDADE URBANA:

O CASO DE SÃO SEBASTIÃO

José Francisco Xavier Magalhães

São Paulo

2015 
José Francisco Xavier Magalhães

\section{EIA-RIMA INSUFICIENTE COMO AVALIAÇÃO DE IMPACTOS AMBIENTAIS ENQUANTO BUSCA DE SUSTENTABILIDADE URBANA: \\ $O$ CASO DE SÃO SEBASTIÃO}

Tese apresentada ao programa de Pós-graduação da Faculdade de Arquitetura e Urbanismo da Universidade de São Paulo como requisito para obtenção do título de doutor.

Área de Concentração:

Planejamento Urbano e Regional

ORIENTADOR:

Professor Dr. Candido Malta Campos Filho

São Paulo

2015 
AUTORIZO A REPRODUÇÃO E DIVULGAÇÃO TOTAL OU PARCIAL DESTE TRABALHO, POR QUALQUER MEIO CONVENCIONAL OU ELETRÔNICO, PARA FINS DE ESTUDO E PESQUISA, DESDE QUE CITADA A FONTE.

E-MAIL AUTOR: jfxmagalhaes@gmail.com

M188e Magalhães, José Francisco Xavier

EIA-RIMA insuficiente como avaliação de impactos

ambientais enquanto busca de sustentabilidade urbana: o caso de

São Sebastiāo / José Francisco Xavier Magalhães. -- São Paulo, 2014. 255 p.: il.

Tese (Doutorado - Área de Concentração: Planejamento Urbano e Regional) FAU-USP. Orientador: Candido Malta Campos Filho

1.Impactos ambientais - São Sebastião (SP) 2.Planejamento urbano regional 3. Meio ambiente 4.Sustentabilidade I.Título

CDU 504.064.3 
Ao arquiteto e urbanista Dr. José Magalhães Jr. 
Os meus mais sinceros agradecimentos ao meu orientador professor Dr. Candido Malta Campos Filho e a todos aqueles que, de alguma maneira, contribuíram com a realização desta pesquisa, em especial aos professores Dr. José Magalhães Jr., Dr. Adilson Costa Macedo, Dr. Angelo Filardo, Fernanda Lemes e ao editor Denis Araki. 
MAGALHÃES. José Francisco Xavier. EIA-RIMA insuficiente como avaliação de impactos ambientais enquanto busca de sustentabilidade urbana: o caso de São Sebastiáo. Tese (Doutorado) - Faculdade de Arquitetura e Urbanismo, Universidade de São Paulo, São Paulo, 2015

O presente trabalho comprova que o atual instrumento EIA-RIMA - Estudo de Impacto Ambiental e seu respectivo Relatório de Impacto Ambiental, é insuficiente enquanto busca de sustentabilidade urbana no Litoral Norte do Estado de São Paulo, especificamente no município de São Sebastião. O método de analise dos EIA-RIMA sempre enfatizam os ganhos econômicos e atenuam os impactos negativos, apesar das fragilidades naturais, estruturais e restrições legais incidentes. A tese comprova que os instrumentos utilizados no âmbito do processo de licenciamento ambiental dos empreendimentos, como a ampliação do porto comercial de São Sebastião, estão pouco comprometidos com o real desenvolvimento sustentável da cidade e região. As especificidades geográficas, sobretudo as facilidades de interface do território terrestre com o marítimo, proporcionadas pelas características naturais do Canal de São Sebastião, sempre ofereceram condições privilegiadas para o abrigo de embarcações, característica decisiva na escolha do lugar como cidade portuária, vinculada aos mais importantes ciclos econômicos do país. Agora, em 2015, está prestes a entrar em um novo ciclo, principalmente com a ampliação do porto comercial, duplicação da rodovia dos Tamoios e da SP-055 e a exploração da camada pré-sal na Bacia de Santos. A região já apresenta todos os problemas de uma ocupação acelerada em um território ambientalmente frágil, localizado em estreita faixa litorânea, composta de um lado pela Serra do Mar e do outro pelo Oceano Atlântico. Se não houver um planejamento urbano e regional que considere as características e capacidade de suporte deste território, a zona costeira entrará em colapso. Saber dosar o uso de suas potencialidades sem esgotá-las será o desafio de nossa geração.

Os Estudos de Impactos Ambientais precisam ser aperfeiçoados para que ações mitigadoras alcancem muito mais do que o mínimo, alinhadas a investimentos, tecnologias inovadoras, infraestruturas necessárias e obrigatórias que sejam pensadas de maneira conjunta e cumulativa nas diversas esferas do poder, com efetiva participação pública, caso contrário, o crescente interesse econômico e político tenderá à destruição irreversível do patrimônio histórico e natural deste território. O EIA está se transformando em um poderoso instrumento político de ordenamento territorial que acaba por definir critérios e parâmetros de uso e ocupação, desempenhando uma função que não lhe compete, além de aprofundar o desencontro entre uma vida urbana de qualidade e um ambiente equilibrado em nome do desenvolvimento econômico e a serviço dos interesses privados.

Palavras-chave: Impactos ambientais - São Sebastião (SP); Planejamento urbano regional; Meio ambiente; Sustentabilidade. 
MAGALHÃES. José Francisco Xavier. EIA - RIMA as insuficient document to evaluate enviromental impacts for urban sustainability: São Sebastião case. Doctoral dissertation - Faculdade de Arquitetura e Urbanismo, Universidade de São Paulo, São Paulo, 2015.

The present thesis proves that the current instrument EIA-RIMA - Environmental Impact Study and its respective Environmental Impact Report, is insufficient in the pursuit of urban sustainability in Northern Shore of São Paulo State, specifically in São Sebastião City. The analysis method of EIA-RIMA always emphasize the economic earns and attenuate the negative impacts, despite the natural and structural frailties and the legal restrictions enforced. This study proves that these instruments applied in the vast process of environmental licenses of the enterprises, as the expansion of the commercial port of São Sebastião, are very little committed with the real sustainable development of the city and region. The geographical specificities, especially the interface facilities between the land and sea, provided by the natural features of São Sebatião Canal, always offered privileged conditions to shelter ships, decisive feature for the decision to install this port town, linked to the many economic cycles of the country. Now, in 2015, it's on the verge of a new cycle, mainly because of the commercial port ampliation, the duplication of Tamoios road and the SP-055, and the exploration of the pre-salt layer in Bacia de Santos. The region already presents all the problems of fast occupation in a land environmentally fragile, located between the narrow seaside strip, composed by one side of Serra do Mar and on the other by the Atlantic Ocean. If there isn't an urban and regional planning that considers the features and support capacity of this land, the coastal zone will collapse. To know how to use it's potential without run out will be the challenge of our generation. The environmental Impact Studies needs to be improved that the mitigation actions reaches much more than the minimum, linked to investments, innovative technology, necessary and obligatory infrastructure thought together and cumulative in the many spheres of power, with effective public participation, otherwise, the growing economical and political interest in the area will lead to the irreversible damage of its historical an natural heritage. The EIA is turning into a powerful political instrument of spatial planning that defines criteria and parameters of use and occupation that they are not designed to, apart from deepening the divergence between a quality urban life and a balanced environment, in name of economical development and serving private interests.

Keywords: Environmental impacts - São Sebastião (SP); Regional urban planning; Environment; Sustainability. 
Figura 1 - Píer para embarcações em São Sebastião - $1910 \quad 26$

Figura 2 - Vila de São Sebastião em 1815

Figura 3 - Projeto de 1940 para ampliação do Porto de São Sebastião 36

Figura 4 - São Sebastião, Ilhabela, Caraguatatuba e Ubatuba. Municípios que compõe o Litoral Norte do estado de São Paulo 37

Figura 5 - Vista aérea do Litoral Norte de São Paulo 38

Figura 6 - Litoral Norte do Estado de São Paulo 39

Figura 7 - Frente de Marítima da cidade de São Sebastião - Século XIX 41

Figura 8 - Frente de Marítima da cidade de São Sebastião, 2014

Figura 9 - Projeto de ampliação do Porto Comercial - São Sebastião 41

Figura 10 - Frente fluvial da cidade Buenos Aires. Bota-fora, $2014 \quad 46$

Figura 11 - Frente Fluvial da cidade Buenos Aires interrompida pelo Puerto Madeiro e pelo aterro, $2014 \quad 46$

Figura 12 - Frente Marítima da cidade de Barcelona, 2014

Figura 13 - Docklands, Londres, 2014

Figura 14 - Porto Maravilha, cidade do Rio de Janeiro, 2014

Figura 15 - Vista aérea do Canal de São Sebastião 50

Figura 16 - Proposta de Hidrovia e Terminal Turístico para Transatlânticos - $1^{\circ}$ lugar no Concurso Nacional para Readequação da Paisagem Urbana do Município de Ilhabela, SP, 1998

Figura 17 - Estudo para Ampliação do Porto Comercial, São Sebastião em $1998 \quad 55$

Figura 18 - Principais rotas ferroviárias - São Paulo, Minas Gerais e Rio de Janeiro 56

Figura 19 - Localização do aterro e obras de desmonte do morro de rocha descomposta na Gleba D do TEBAR, em São Sebastião - SP 62

Figura 20 - Layout geral dos aterros em São Sebastião-SP 62

Figura 21 - Foto aérea - São Sebastião $\quad 64$

Figura 22 - Proposta para o Porto de Recreio da cidade de São Sebastião 65

Figura 23 - Proposta para o Porto de Recreio da cidade de São Sebastião 66

Figura 24 - Zoneamento proposto para o centro da cidade de São Sebastião 68

Figura 25 - Fotomontagem da proposta para o Porto de Recreio da cidade de São Sebastião 69

Figura 26 - Projeto de urbanização do aterro de São Sebastião, elaborado pela prefeitura de São Sebastião

Figura 27 - Implantação do projeto de urbanização do aterro de São Sebastião, 201473 
Figura 28 - Sanitários e Centro de Informação Turística

Figura 29 - Quiosques de artesanato $\quad 74$

Figura 30 - Concha acústica $\quad 74$

Figura 31 - Píer apenas para contemplação $\quad 74$

Figura 32 - Lanchonetes $\quad 74$

Figura 33 - Observatório ambiental $\quad 74$

Figura 34 - Proposta de ampliação do porto comercial de São Sebastião. Cenário para $2030 \quad 75$

Figura 35 - Proposta de ampliação do porto comercial de São Sebastião. Cenário para 2030

Figura 36 - Processo de transformação da região do Porto de São Sebastião, período 1962 a 2030

Figura 37 - Plano Geral Metropolitano - reprodução do mapa editado pela Corporació Metropolitana de Barcelona, 1976

Figura 38 - Novas centralidades: dez setores com propostas para requalificação destas áreas

Figura 39 - Área que o Plano de Costas contempla, deste o município de Sitges até Montgat

Figura 40 - Frente marítima de Poblenou na década de $1980 \quad 86$

Figura 41 - Garraf, município de Stiges - barreira ferroviária 86

Figura 42 - Frente marítima entre os municípios de Sitges (les Boutigues) até Castelldefels e Gavà

Figura 43 - Frente marítima entre os municípios de Villadecans até El Prat del Llobregat

Figura 44 - Frente marítima entre os municípios de Barcelona, Sant Adrià de Besós, Badalona, até Montgat

Figura 45 - Zona industrial de Badalona 89

Figura 46 - Porto de Arenys: interrupção das correntes de areia do NE-SO 90

Figura 47 - Porto de Barcelona - Plano Geral 93

Figura 48 - Porto de Barcelona. 93

Figura 49 - Porto de Barcelona e o terminal turístico World Trade Center 95

Figura 50 - Novo acesso do Porto de Barcelona 96

Figura 51 - Hotel e nova marina $\quad 97$

Figura 52 - Novo acesso do Porto de Barcelona 98

Figura 53 - Porto de Barcelona: local da nova entrada para o Porto 100 
Figura 54 - Porto de Barcelona. Propostas de abertura para o porto (segunda entrada)

Figura 55 - Nova frente marítima da cidade de Barcelona.

Figura 56 - Projeto inicial para o bairro Nova Icària com prolongamento da av.

Paseo Carlos I, terminando em uma praça marítima

Figura 57 - Praça d'água antes das adequações olímpicas

Figura 58 - Maquete - Porto olímpico e o bairro Nova Icària 105

Figura 59 - Maquete - Porto olímpico já com as adequações 105

Figura 60 - Porto olímpico de Barcelona 106

Figura 61 - Frente marítima de Barcelona - porto olímpico 107

Figura 62 - Barreiras ferroviária na área urbana 108

Figura 63 - Vista aérea da cidade de Barcelona desde o município de Sitges até Montgat

Figura 64 - Linha do tempo da legislação ambiental brasileira - período 1934 a 1988127

Figura 65 - Linha do tempo da legislação ambiental brasileira - período 1989 a 1994137

Figura 66 - Linha do tempo da legislação ambiental brasileira - período 1997 a 2002142

Figura 67 - Linha do tempo da legislação ambiental brasileira - período 2002 a 2014150

Figura 68 - Setorização do litoral paulista 164

Figura 69 - Zoneamento Ecológico Econômico do Litoral Norte 171

Figura 70 - Transferência de petróleo entre os píeres do TEBAR e as refinarias de São Paulo

Figura 71 - Ilustração das alternativas locacionais das propostas para o novo píer do Terminal de São Sebastião

Figura 72 - Alternativa 3 escolhida para a ampliação do Píer Petroleiro Terminal Aquaviário de São Sebastião

Figura 73 - Duplicação da rodovia dos Tamoios - Trecho Planalto, Serra, Contornos Sul e Norte de Caraguatatuba.

Figura 74 - Duplicação da rodovia dos Tamoios - Trecho Planalto 183

Figura 75 - Duplicação da rodovia dos Tamoios - Trecho Serra 185

Figura 76 - Contornos Sul e Norte de Caraguatatuba 187

Figura 77 - Bacia de Santos - camada pré-sal 188

Figura 78 - Camada pré-sal da Bacia de Santos 189

Figura 79 - Alternativas para recebimento em terra do gás proveniente da plataforma Mexilhão - Bloco BS 400

Figura 80 - Localização para ampliação do porto comercial - São Sebastião 
Figura 81 - Ampliação do porto comercial - São Sebastião. Apresentação de quatro alternativas

Figura 82 - São Sebastião em 2030. A cidade suportará o impacto do projeto apresentado?

Figura 83 - Com 397 metros de comprimento e 63 metros de largura, o Emma Maerks é atualmente o maior navio de contêineres do mundo, operando no maior porto do mundo, em Rotterdam, na Holanda

Figura 84 - Espacialização dos principais empreendimentos na região do Porto de São Sebastião. Não está presente em nenhum dos EIA-RIMA estudados anteriormente para compreender os efeitos cumulativos e sinergéticos em uma mesma base de dados

Figura 85 - RMVP dentro do contexto da Macrometrópole

Figura 86 - Cobertura vegetal dentro da RMVPLN

Figura 87 - Sub-regiões da RMVPLN - destaque para a sub-região 5 (Litoral Norte do Estado de São Paulo) 
Tabela 1 - População estimada - ano de 2014

Tabela 2 - Número de embarcações por habitantes no mundo 99

Tabela 3 - Número de embarcações por habitantes no Brasil 99

$\begin{array}{ll}\text { Tabela } 4 \text { - Categorias de Unidades de Conservação por grupo } & 147\end{array}$

Tabela 5 - Atuais instalações e as pretendidas para a ampliação do porto 193

Tabela 6 - Atração de População 199

Tabela 7 - Aumento da demanda por habitações 199

Tabela 8 - Dinamização do mercado imobiliário 200

Tabela 9 - Alterações nas condições de operação do sistema viário 200

Tabela 10 - Alterações na paisagem $\quad 201$

Tabela 11 - Interferência na atividade da pesca artesanal 202

Tabela 12 - Interferência no patrimônio arqueológico 202

Tabela 13 - Degradação das áreas urbanas no entorno do porto 202

Tabela 14 - Descaracterização do centro histórico 203

Tabela 15 - Demanda por áreas de estacionamento e apoio aos caminhoneiros $\quad 204$

Tabela 16 - Criação de condições propícias ao estabelecimento de manguezal 204

Tabela 17 - Geração de empregos e renda 205

Tabela 18 - Animação da atividade econômica 205

Tabela 19 - Aumento das receitas fiscais 206

Tabela 20 - Desenvolvimento da infraestrutura portuária e de apoio 206

Tabela 21 - Consequências negativas para a região 210 
AAE: Avaliação Ambiental Estratégica

ABNT: Associação Brasileira de Normas Técnicas

AIA: Avaliação de Impacto Ambiental

AID: Área de Influência Direta

AII: Área de Influência Indireta

ANA: Agência Nacional de Águas

APP: Área de Preservação Permanente

CETESB: Companhia de Tecnologia de Saneamento Ambiental

CIB: Conselho Internacional da Construção

CONAMA: Conselho Nacional do Meio Ambiente

CONDEPHAAT: Conselho de Defesa do Patrimônio Histórico, Arqueológico, Artístico e Turísti-

co do Estado de São Paulo

CODESP: Companhia Docas do Estado de São Paulo

CPTM: Companhia Paulista de Trens Metropolitanos

CF: Constituição Federal

DAEE: Departamento de Águas e Energia Elétrica

DCTA: Departamento de Ciência e Tecnologia Aeroespacial

DERSA: Desenvolvimento Rodoviário S/A

EMBRAER: Empresa Brasileira de Aeronáutica

EIA: Estudo de Impacto Ambiental

EIV: Estudo Prévio de Vizinhança

EMPLASA: Empresa Paulista de Planejamento Metropolitano

IBAMA: Instituto Brasileiro do Meio Ambiente e dos Recursos Naturais Renováveis

IBGE: Instituto Brasileiro de Geografia e Estatística

ICMBio: Instituto Chico Mendes de Conservação da Biodiversidade

IDH: Índice de Desenvolvimento Humano

IGC: Instituto Geográfico e Cartográfico

INPE: Instituto Nacional de Pesquisas Espaciais

IPHAN: Instituto do Patrimônio Histórico e Artístico Nacional

ITA: Instituto Tecnológico de Aeronáutica

LI: Licença de Instalação

LO: Licença de Operação

LP: Licença Prévia

MMA: Ministério do Meio Ambiente

MRS: Malha Regional Sudeste

NEPA: National Environmental Policy Act

RAP: Relatório Ambiental Preliminar

RIMA: Relatório de Impacto Ambiental

PNGC: Plano Nacional de Gerenciamento Costeiro

PAF: Plano de Ação Federal da Zona Costeira

PIB: Produto Interno Bruto

PIPC: Plano Integrado Porto Cidade

PEGC: Plano Estadual de Gerenciamento Costeiro

PMGC: Plano Municipal de Gerenciamento Costeiro

PNUD: Programa de Desenvolvimento das Nações Unidas

TEU: Twenty-foot Equivalent Unit 
SABESP: Companhia de Saneamento Básico do Estado de São Paulo SEADE: Sistema Estadual de Análise de Dados

SEAQUA: Sistema Estadual de Administração da Qualidade Ambiental, Proteção, Controle e Desenvolvimento do Meio Ambiente e Uso Adequado dos Recurso Naturais

SIGERCO: Sistema de Informaçóes do Gerenciamento Costeiro

SMA: Secretaria do Meio Ambiente

RQA-ZC: Relatório de Qualidade Ambiental da Zona Costeira

ZEEC: Zoneamento Ecológico Econômico Costeiro

TEBAR: Terminal Marítimo Almirante Barroso

TCCA: Termos de Compromisso de Compensação Ambiental 
CAPÍTULO I - LITORAL NORTE DO ESTADO DE SÃO PAULO

A cidade de São Sebastião e sua transformação urbana

1. $\quad$ LITORAL NORTE DO ESTADO DE SÃO PAULO

1.1 A cidade de São Sebastião

\section{CAPÍTULO II - ZONAS PORTUÁRIAS}

0 caso do Porto de São Sebastião do Estado de São Paulo

2. ZONAS PORTUÁRIAS

$2.1 \quad$ Portos comerciais $\quad 45$

2.2 Centro histórico de São Sebastião cada vez mais distante da orla marítima 48

2.3 O Canal de São Sebastião, SP - hidrovia natural $\quad 49$

2.4 Cabotagem e carga de projeto com alternativa aos contêineres $\quad 53$

$\begin{array}{ll}2.5 & \text { Transporte ferroviário__ }\end{array}$

\begin{tabular}{ll}
2.6 & Litoral e o Porto de Santos_ \\
\hline
\end{tabular}

CAPÍTULO III - 0 ATERRO

São Sebastião e a implantação do aterro em frente ao seu centro histórico

3. O ATERRO E O CENTRO HISTÓRICO DE SÃO SEBASTIÃO 61

3.1 História da implantação do aterro de São Sebastião $r$

3.2 EIA-RIMA do aterro em frente ao centro histórico de São Sebastião 63

3.3 Revitalização urbana do centro histórico de São Sebastião 63

3.4 0 potencial perdido no centro histórico de São Sebastião 68

$\begin{array}{ll}3.5 & \text { São Sebastião } 2030 \\ \end{array}$

\section{CAPÍTULO IV - PLANO DE COSTAS PARA A CIDADE DE BARCELONA}

A recuperação da faixa metropolitanana da cidade de Barcelona

4. PROPOSTA DE ORDENAÇ̃̃O DA ZONA COSTEIRA METROPOLITANA DE BARCELONA 81

4.1 Desenvolvimento do Plano de Costas

4.2 Obras náuticas

4.2.1 Porto de Barcelona

Ampliação do Porto Central de Barcelona

$\begin{array}{llr}4.2 .3 & \text { Portos desportivos } & 98\end{array}$

$\begin{array}{lr}\text { 4.2.4 Marina do porto urbano de Barcelona } & 100\end{array}$

$\begin{array}{llr}4.2 .5 & \text { Porto olímpico } & 101\end{array}$

$\begin{array}{llr}4.3 & \text { Aeroporto } & 106\end{array}$

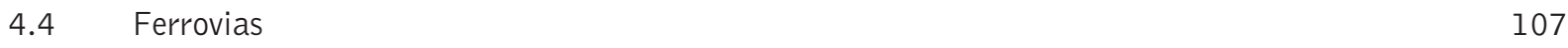

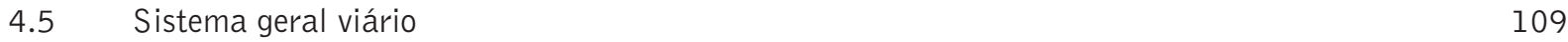

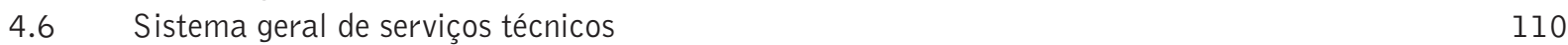

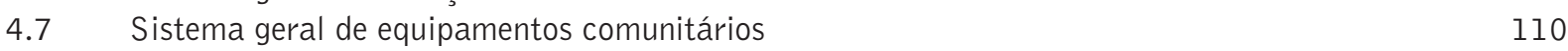

$\begin{array}{ll}4.8 & \text { Sistema geral de parques e jardins urbanos } \\ 4.910\end{array}$

4.9 Cronologia - Desenvolvimento do Plano de Costas 111

CAPÍTULO V - ESTUDO DE IMPACTO AMBIENTAL - EIA

0 antagonismo da sutentabilidade

5. 0 EIA-RIMA E A SUSTENTABILIDADE 117

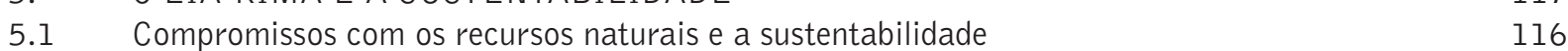

$\begin{array}{lr}5.2 & \text { Sustentabilidade urbana } \\ 5.322\end{array}$

$\begin{array}{ll}5.3 & 0 \text { PAC e a sustentabilidade urbana } \\ \end{array}$ 


\section{CAPÍTULO VI - ARCABOUÇO LEGAL}

Legislação ambiental e o Estudo de Impacto Ambiental - EIA

6. LEGISLAÇÃO AMBIENTAL E O ESTUDO DE IMPACTO AMBIENTAL - EIA 127

Considerações finais sobre a legislação ambiental

\section{CAPÍTULO VII - GERENCIAMENTO COSTEIRO DO LITORAL NORTE}

Faixa litorânea - espaço finito

7. FAIXA LITORÂNEA - ESPAÇO FINITO

7.1 Plano de Gerenciamento Costeiro do Estado de São Paulo

7.2 Macrozoneamento do Litoral Norte do Estado de São Paulo

Zoneamento Ecológico Econômico - São Sebastião

\section{CAPÍTULO VIII - PROJETO DE SIGNIFICATIVO IMPACTO AMBIENTAL}

São Sebastião - São Paulo/SP

$8 \quad$ PROJETOS DE GRANDE IMPACTO AMBIENTAL EM SÃO SEBASTIÃOO

8.1 Ampliação do Píer Petroleiro Terminal Aquaviário de São Sebastião 175

8.2 Duplicação da rodovia dos Tamoios $r$

8.3 Trecho Planalto (SP-099) 182

$\begin{array}{llr}\text { 8.4 Trecho Serra - Duplicação da rodovia dos Tamoios } & 184\end{array}$

8.5 Contorno Sul - Caraguatatuba /São Sebastião $r$

8.5.1 Contorno Norte $\quad 187$

8.6 EIA-RIMA - Projetos integrados de produção e escoamento de petróleo e gás natural no polo pré-sal - Bacia de Santos $\quad 188$

$\begin{array}{lll}\text { 8.7 } & \text { EIA - Unidade de Tratamento de Gás de Caraguatatuba (UTGCA) } & 191\end{array}$

8.8 EIA-RIMA - ampliação do Porto de São Sebastião - Plano Integrado Porto Cidade
(PIPC SÃO SEBASTIÃO)

8.9 Ampliação do porto para contêineres e suas consequências 208

8.10 Considerações finais dos EIA em São Sebastião 209

CAPÍTULO IX- REGIÃO METROPOLITANA DO VALE DO PARAÍBA E LITORAL NORTE Uma alternativa para a região costeira

9 RMVP - Região Metropolitana do Vale do Paraíba e Litoral Norte 215

9.1 Uma possibilidade para a zona costeira - território frágil ambientalmente 219

$\begin{array}{ll}9.2 & 0 \text { instrumento EIA-RIMA pode ser otimizado? }\end{array}$

\section{CAPÍTULOX - SIMULADORES URBANOS}

Capacidade de suporte do território

10 SIMULADORES URBANOS

$10.1 \quad$ Capacidade de suporte do território

\section{CAPÍTULOXI}

Conclusão

$11.1 \quad$ Como compensar ou mensurar um dano ambiental considerado irreversível?

11.2 Insuficiência dos Estudos de Impactos Ambientais na cidade de São Sebastião enquanto busca de sustentabilidade urbana 236

11.3 Faltam estudos com visão global 
INTRODUÇÃO

$\Lambda_{\text {interfaces do território terrestre com o marítimo, nas principais baías e portos naturais, pro- }}^{\text {s condiçes geográficas únicas e exclusivas do litoral brasileiro, sobretudo as facilidades das }}$ porcionaram condições privilegiadas para a navegação e defesa militar. Tais características foram decisivas na escolha dos primeiros assentamentos, que estiveram sempre vinculados aos diversos ciclos econômicos nacionais. Estes lugares conquistaram importância regional e acabaram por consolidar zonas portuárias.

Segundo Milton Santos e Maria Laura Silveira, no livro O Brasil: território e sociedade no início do século XXI, a ocupação do território brasileiro poderia ser entendida a partir de seu uso, considerado por eles um ator na dinâmica social, o que justificaria a atual formação socioespacial. Em outra interpretação, de Caio Prado Jr. em sua obra História econômica do Brasil, a ocupação pode ser separada por períodos, ${ }^{1}$ desde a ocupação preliminar do território brasileiro até a crise do sistema em 1930. Já Celso Furtado, no livro Formação econômica do Brasil, compreende a história do território brasileiro através dos fundamentos econômicos da ocupação inicial do território, com uma economia escravagista da agricultura tropical entre o século XVI e XVII, economia escravagista mineira no século XVIII, trabalho assalariado no século XIX (imigração europeia) com crise do café e transição para economia industrial.

Santos e Maria Silveira apresentam formas alternativas de se pensar sobre a ocupação do território brasileiro, seja pela economia ou por seu povo e cultura, mas concluem que o ator principal para essa compreensão pode ser a própria configuração do território e a forma como ele é utilizado. O uso do território foi definido pelos autores em três fases: meios "naturais" (natureza comanda as ações do homem), meios técnicos (equipamentos controlando a natureza) e os meios técnico-científico-informacionais (união de ciência, da técnica e da informação).

\footnotetext{
${ }^{1}$ Temporalidade do processo de ocupação do território brasileiro segundo Caio Prado Jr.: 1500 - 1530: Ocupação preliminar do território.

1530 - 1640: Ocupação efetiva (início da agricultura e atividades acessórias).

1640 - 1770: Expansão da colonização (centro-sul - mineração, nordeste - pecuária e início da exploração do Amazonas).

1770 - 1808: Auge da colônia (agricultura em expansão).

1808 - 1850: Liberalismo (declínio do pacto colonial e início do capitalismo industrial).

1850 - 1889: Império escravocrata (evolução agrícola, abolição da escravatura e início da imigração).

1889 - 1930: República burguesa (industrialização e imperialismo).

Após 1930: Crise do sistema.
} 
No Litoral Norte do estado de São Paulo fica evidente as três fases descritas acima, quando compreendemos a ocupação urbana da cidade de São Sebastião.

As características naturais do lugar permitiram a ocupação do território estabelecendo um contato direto com as águas navegáveis, ou seja, o principal fator levado em consideração neste período foi a posição geográfica privilegiada e específica dos ancoradouros naturais, próprios para aportar embarcações e permitir as operações seguras de embarque e desembarque.

As facilidades de acesso aos recursos naturais viabilizaram maiores investimentos em equipamentos para controlar ainda mais a natureza e agilizar as operaçôes comerciais, mas ao mesmo tempo em que o caráter portuário proporcionava o desenvolvimento econômico, iniciava-se também um processo de separação do centro urbano de suas frente marítima, resultando na ruptura do tecido urbano.

O atual projeto apresentado para a ampliação do Porto de São Sebastião, através do EIA-RIMA (Estudo de Impacto Ambiental e Relatório de Impacto Ambiental), ${ }^{2}$ agravará os problemas urbanos e aprofundará ainda mais a desarticulação entre porto e cidade.

Seguindo exemplos de outros lugares do mundo, como o Plano de Costa para Barcelona na Espanha, conforme veremos no capítulo 4 deste trabalho, a ampliação do Porto de São Sebastião seria uma oportunidade de reaproximar a cidade e seu centro histórico da sua orla marítima. Pensar uma expansão onde o conhecimento e a possibilidade de modelar, desenhar e comparar futuros cenários, considerando suas especificidades territoriais e, consequentemente, sua capacidade de suporte, ${ }^{3}$ sejam levadas em conta para definircom maior precisão um plano urbano e seus respectivos e necessários investimentos, muito mais adequados para um desenvolvimento sustentável da cidade e de seu centro histórico.

Se considerarmos que possuímos uma série de legislações ambientais ainda em evolução, que exigem EIA-RIMA com participação pública para atividades consideradas efetiva ou potencialmente causadoras de significativa degradação do meio ambiente, como é o caso da ampliação do porto comercial de São Sebastião, além da tecnologia que temos disponível, junto ao em-

\footnotetext{
${ }^{2}$ A Resolução Federal do Conselho Nacional do Meio Ambiente, CONAMA 001/86, através da Política Nacional de Meio Ambiente instituída em 1981 pela Lei 6938/81, estabelece os procedimentos, critérios e diretrizes gerais para a elaboração dos Estudos de Impacto Ambiental (EIA) e respectivo Relatório de Impacto Ambiental (RIMA), necessários ao processo de licenciamento a todo empreendimento considerado de significativo impacto ambiental, com potencial de degradação ou poluição. No Art. $1^{\circ}$, considera impacto ambiental qualquer alteração das propriedades físicas, químicas e biológicas do meio ambiente, causada por qualquer forma de matéria ou energia resultante das atividades humanas que, direta ou indiretamente, afetam:

I - a saúde, a segurança e o bem-estar da população; II - as atividades sociais e econômicas; III - a biota; IV - as condiçôes estéticas e sanitárias do meio ambiente; $\mathrm{V}$ - a qualidade dos recursos ambientais.

3 A capacidade de suporte determina o quanto o território pode ser "utilizado", sem entrar em colapso, em relação a infraestrutura existente e/ou em relação aos seus recursos ambientais. É possível calcular através de simuladores matemáticos qual é este limite, além de prever quais são as açōes necessárias para ampliar, caso seja possível, a capacidade de suporte e ainda garantir sua sustentabilidade.

Em resumo, é o limite em que o meio ambiente e urbano conseguem manter suas características em equilíbrio, apesar das intervenções e ocupações humanas, antes de o sistema entrar em colapso.
} 
basamento técnico-científico-informacional que auxiliam no entendimento da capacidade de suporte do território (evidenciar e antecipar os possíveis cenários de nossas cidades, controlar os aspectos negativos e ainda corrigir o rumo para uma hipótese previamente definida), poderíamos concluir que estamos no caminho certo. Mas, como veremos neste trabalho, os resultados dos diversos estudos ambientais elaborados nos últimos anos para o Litoral Norte do estado de São Paulo indicam o contrário, mostrando que os esforços ainda são insuficientes na busca da sustentabilidade urbana.

Veremos que as novas tecnologias para um melhor conhecimento da capacidade de suporte da região e da previsão de seu futuro não estão sendo utilizadas, além da possibilidade dos atuais Estudos de Impacto Ambiental terem sido manipulados e/ou controlados para justificar um determinado tipo de empreendimento e obter o quanto antes licenças ambientais, sem garantias reais da utilização sustentável dos recursos naturais e preservação de seu patrimônio históricocultural.

O instrumento EIA pode não aprofundar intencionalmente seus estudos em relação ao contexto natural, urbano, histórico e cultural da região onde o empreendimento pretende ser implantado, minimizando os impactos negativos nestes atributos, para evidenciar e valorizar com maior ênfase os benefícios econômicos e sociais.

O aterro licenciado e construído na década de 1980, em frente ao centro histórico da cidade de São Sebastião, pode ser considerado uma comprovação da fragilidade destes estudos. O EIARIMA utilizou como principal argumento para licenciar o aterro a de que sua construção seria responsável por benefícios socioeconômicos positivos, tanto na escala local quanto na escala regional, pois viabilizaria novas áreas de lazer e de recreio. Justificou também que a cidade de São Sebastião não possuía espaço para futuras ampliações de sua malha urbana por contar com um "forte condicionante", a presença da Serra do Mar. Mas não menciona os outros dois condicionantes que ocuparam grande parte das áreas disponíveis, o próprio porto e as instalações da Petrobras.

Com a construção do aterro, a importante e histórica relação cidade-mar, conforme Figura 1, foi perdida. Em nenhum momento o EIA-RIMA considerou em seus estudos a importância deste espaço de maneira mais responsável e o aterro ficou por mais de 23 anos abandonado. 


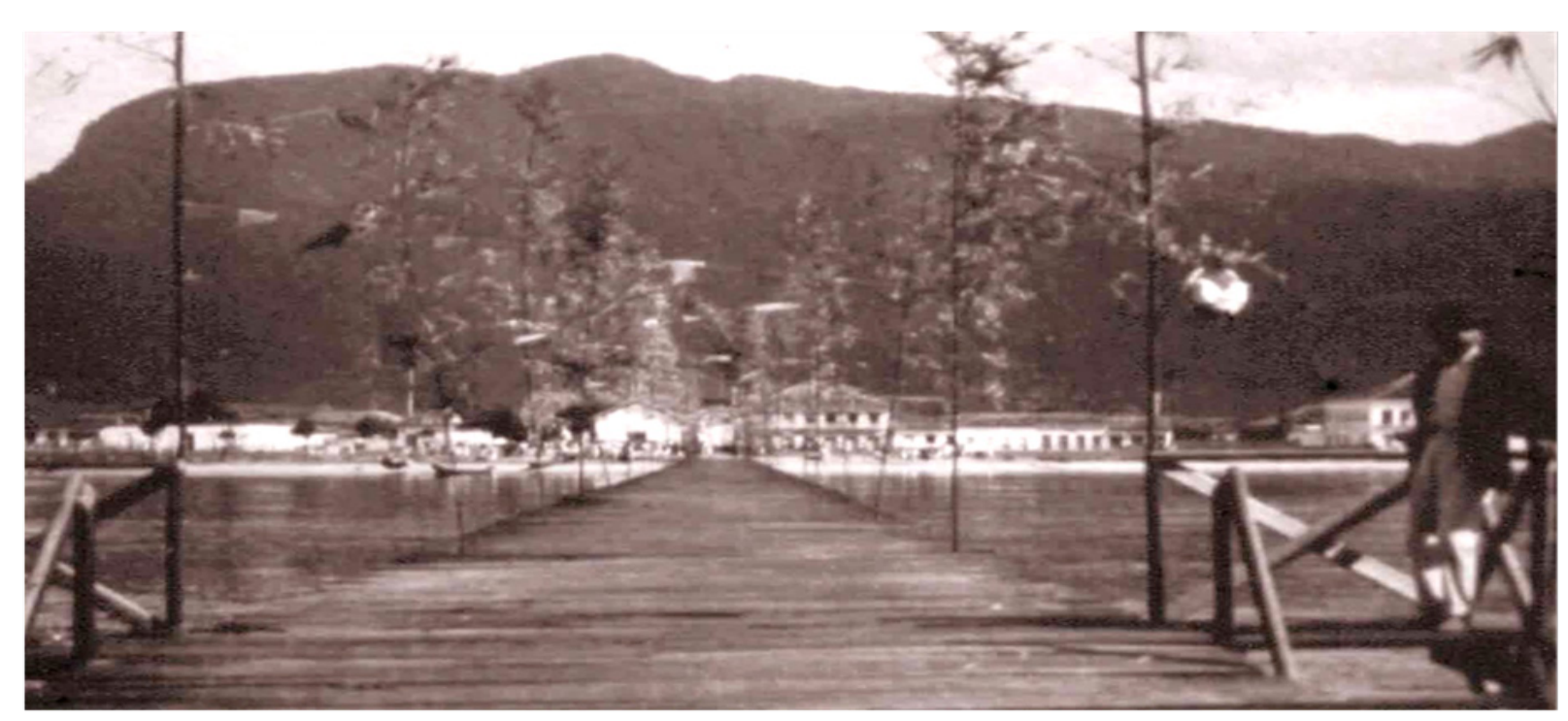

Fonte: G. Sazone - Reprodução Edivaldo Nascimento.

Figura 1 - Píer para embarcações em São Sebastião - 1910

Os locais navegáveis e abrigados, na sua grande maioria, estiveram vinculados à navegação comercial e colaboraram na consolidação das principais cidades costeiras brasileiras. Tais características foram e são fundamentais para estas regiões com a consolidação dos portos comerciais, resultado dos diversos ciclos econômicos. Tais locais são responsáveis também por condicionar as adequaçôes espaciais da cidade, ao mesmo tempo que passaram a funcionar como territórios desconectados do tecido da cidade e regidos por leis próprias. Esta situação acabou por provocar a ruptura e o distanciamento das atividades urbanas de suas fronteiras com a linha d'água e ainda desencadear processos de desvalorização do seu entorno.

A partir das novas necessidades comerciais, como a ampliação de áreas para estocagem, geralmente paralelas à linha de costa, e mais recentemente com os retroportos (movimentação de contêineres), os portos modificaram ainda mais os seus modelos de ocupação urbana.

O sistema de transporte por contêineres precisa do retroporto, que utiliza áreas muito amplas e um sistema de movimentação bastante desenvolvido para manter a regularidade de escoamento das mercadorias, com infraestrutura viária e ferroviária instaladas e adequadas às demandas previstas. No caso da cidade de São Sebastião, que pretende ampliar seu porto comercial para movimentação de contêineres, essa infraestrutura é exatamente o que não existe, principalmente para as áreas de estocagem.

Pouco se argumentou sobre uma outra configuração comercial portuária, onde a ênfase não estivesse neste tipo de carga. O cálculo da capacidade de suporte do território, simulando e comparando cenários futuros e seus impactos, poderia subsidiar discussóes com os diversos setores da sociedade sobre este assunto.

Outro ponto tocado de forma periférica nos diversos EIA-RIMA são os reais reflexos negativos dos diversos empreendimentos na região, mais especificamente no município de Ilhabela, com a ampliação do Porto de São Sebastião. 
Um arquipélago marítimo, considerado Estância Balneária, Ilhabela sofrerá os mesmos efeitos que provavelmente atingirão o canal de São Sebastião, comprometendo também seu patrimônio ambiental. Pela proximidade com o Porto de São Sebastião, após sua futura ampliação o município será alvo da especulação imobiliária, ocupações irregulares, maior pressão em suas áreas de preservação permanente e consequentemente de todos os seus desdobramentos, como aumento da produção de lixo, esgoto e novas demandas por infraestrutura urbana. Mas o estudo considera apenas o bairro Barra Velha no município de Ilhabela, no trecho junto à balsa, como Área de Influência Direta (AID) do empreendimento licenciado.

Baseado nas análises dos EIA-RIMA elaborados para o Litoral Norte do estado de São Paulo, podemos afirmar que todos minimizam a importância dos impactos ambientais negativos e evidenciam os ganhos econômicos e sociais para a cidade e região, onde as propostas para mitigação e/ou compensações recomendadas pelos estudos são mínimas, o que não poderia ser diferente já que o empreendedor é o maior interessado e responsável pela remuneração dos EIA-RIMA. Na verdade, é o início de um pacto em que as contrapartidas são mínimas para que o empreendimento receba suas licenças ambientais.

Como veremos, a cidade de São Sebastião está atualmente sujeita a diversos EIA-RIMA ${ }^{4}$ e a critérios pontuais e particulares de desenvolvimento urbano e econômico, o que resulta em interesse e até subordinação do poder público com menor resistência e exigências à implantação destes grandes empreendimentos. Se não houver um planejamento urbano e regional mais sustentável, que leve em conta as características e limitações deste território, estudos reais, aprofundados e imparciais que comprovem sua real capacidade de suporte, o crescente interesse econômico e político tenderá à destruição irreversível do patrimônio histórico cultural e natural da região.

O desafio será dosar os usos de suas potencialidades sem esgotá-las, com a correta utilização dos instrumentos legais para licenças ambientais verdadeiras, açôes mitigadoras que alcancem muito mais do que o mínimo e garantias de investimentos em infraestrutura dimensionadas para atender as atuais e futuras demandas, pensadas de maneira conjunta nas diversas esferas do poder e com efetiva participação pública.

No livro Cidades brasileiras: seu controle ou caos, Candido Malta Campos Filho apresenta que a organização de nossas cidades e o resultado da produção, apropriação e consumo do espaço urbano está em desequilíbrio, gerada principalmente pela distribuição desigual da renda, e que será necessário uma nova estratégia de desenvolvimento urbano, levando em consideração a função social da propriedade para fins urbanos e a fundamental participação popular neste processo, junto com o combate à especulação imobiliária e a humanização das cidades.

\footnotetext{
${ }^{4}$ Ampliação do porto comercial e porto aquaviário, duplicação da Rodovia Tamoios, contorno sul e norte, duplicação da SP-055 e exploração da camada pré-sal na bacia de Santos.
} 
(...) A humanização das cidades só será obtida com o progressivo controle, pelos cidadãos, $d a$ ação do Estado, fazendo-a voltar-se para a produção de benefícios para a sociedade. Tais beneficios, se obtidos de forma isolada, desconectadas da visão entrelaçada dos problemas, criam uma ilusão de solução e só agravam as distorções da sociedade, afetando a todos. (CAMPOS FILHO, Candido Malta, 1992, p.136)

Será necessário maior e permanente resistência da sociedade para contrapor os interesses privados, principalmente, e exigir do setor público um planejamento e desenvolvimento urbano muito mais suficiente do que vem acontecendo atualmente no município de São Sebastiāo, sujeito a diversos empreendimentos considerados de significativo potencial de degradação ou poluição, que utilizarão de maneira significativa os recursos ambientais e ainda trarão grande impacto na infraestrutura urbana da cidade e região, que já não atende de maneira satisfatória às atuais demandas.

A Resolução CONAMA no 237 de 1997 regulamentou os empreendimentos a estarem sujeitos à avaliação de impactos ambientais para obtenção de licença ambiental através do Estudo Prévio de Impacto Ambiental (EIA) e respectivo Relatório de Impacto Ambiental (RIMA), um dos instrumentos da política Nacional do Meio Ambiente e instituído pela Resolução CONAMA no 001/86, de 23/01/1986.

Todo empreendimento considerado de significativo potencial de degradação ou poluição está sujeito ao processo de licenciamento e depende do estudo de impacto para seu licenciamento ambiental.

Para realização do estudo de impacto ambiental, deverá ser mobilizada uma equipe multidisciplinar contendo engenheiros ambientais, civis, geólogos, biólogos, arquitetos, urbanistas, químicos, geógrafos, gestores ambientais, advogados, entre outros profissionais, que serão responsáveis pelos estudos do meio físico, biológico e socioeconômico. Este estudo será analisado pelo IBAMA ou órgão licenciador e apresentado ao público através de audiências para esclarecimento, sugestões e possíveis alterações, antes da autorização denominada Licença Prévia (LP). Quando um EIA-RIMA é necessário, deve garantir a saúde, a segurança e o bem-estar da população, a continuidade das atividades sociais e econômicas, a preservação da biota, amanutenção das condições estéticas e sanitárias do meio ambiente e a qualidade dos recursos ambientais.

Mas é isto o que está ocorrendo? Os atuais estudos garantem em que medida os diversos itens citados?

Como veremos, os EIA-RIMA elaborados para o Litoral Norte de São Sebastião estão sendo desenvolvidos de forma fragmentada e com pouca profundidade no efeito cumulativo das diversas intervençôes. Logicamente estão a serviço de seus clientes, buscando como resultado comprovar que o empreendimento é viável e que o dano ambiental e social é sempre mínimo e de fácil mitigação.

Um EIA-RIMA mal elaborado, que não informe ou não se aprofunde em seus estudos, poderia ser considerado um crime ambiental? 
Sim. Segundo resolução 237/90, a responsabilidade está prevista tanto para o empreendedor quanto para a equipe que elaborou o EIA-RIMA. Podem sofrer sanções por negligência, imprudência e imperícia. O artigo 72 da lei 9605/1988, estabelece punições que vão de simples advertências até o cancelamento das licenças.

Mas e o órgão licenciador, também poderá ser responsabilizado por emitir uma licença ambiental que mais tarde seja comprovada como insuficiente frente aos resultados alegados como positivos nos estudos? E os riscos ambientais muito mais graves do que foram estimados, como, por exemplo, da exploração da camada pré-sal na Bacia de Santos?

Podemos lembrar a explosão em águas profundas na plataforma British Petroleum Deepwater Horizon, em 2010, responsável pelo vazamento de 4 milhões de barris de petróleo, considerado o pior acidente ambiental dos EUA, que poluiu toda a costa do Golfo do México com gasto inicial de 8 bilhōes de dólares para estancar e conter o avanço do vazamento que durou aproximadamente dois meses. As investigações concluíram que o acidente foi causado por uma sucessão de erros e falhas mecânicas, humanas, de engenharia de projeto, execução e operação, inclusive na contenção do vazamento. ${ }^{5}$

Outro exemplo recente e brasileiro de vazamento no fundo do mar foi o que ocorreu na Bacia de Campos, litoral norte do Rio de Janeiro, em 2011. De responsabilidade da empresa Chevron Latin America e da Transocean Brasil, provocou uma mancha de $162 \mathrm{~km}^{2}$ no mar com vazamento de aproximadamente 882 barris de petróleo.

As empresas foram obrigadas a pagar uma multa de R \$ 35 milhões à Agência Nacional de Petróleo (ANP) pelo vazamento e assinaram um Termo de Ajuste de Conduta (TAC) para ações de prevenção, investimentos e melhorias compensatórias socioambientais de $\mathrm{R} \$ 95$ milhôes. ${ }^{6}$

Lembramos também o destino da P-36, da Petrobras, na Bacia de Campos, considerada a maior plataforma de petróleo do mundo em 2001. Em apenas um ano de funcionamento já era responsável por 6\% da produção nacional (80.000 barris de petróleo/dia). Ela afundou em função de três explosões, causando um prejuízo de US\$ 430 milhões, além da morte de 11 funcionários. Segundo a ANP (Agência Nacional do Petróleo) e a Marinha, o acidente foi causado por erros de projeto, falta de manutenção e operação equivocada.

EmSãoSebastião,osdesastresambientaisrelacionadosaosvazamentosdepetróleotambémsãocomuns, conforme levantamentos. Em maio de 1994 o rompimento de um oleoduto despejou quase 3 milhôes de litros de óleo, contaminado o mar, córregos e afetando 18 praias. Em março e novembro de 2000, foram

\footnotetext{
5 A Transocean, empresa suíça, é acusada de erros na avaliação de testes de pressão de alguns equipamentos e a Halliburton, empresa americana, responsável pelo fechamento do duto, foi acusada de não ter executado de forma adequada a vedação com cimento. Disponível em: <http://veja.abril.com.br/noticia/internacional/sequencia-de-falhas-causou-vazamento-de-petroleo-diz-bp>. Acesso em: 25/04/2014.

${ }^{6}$ Disponível em: <http://g1.globo.com/economia/negocios/noticia/2013/09/chevron-assina-tac-com-mpf-apos-vazamentos-de-petroleo-no-rj.html>. Acesso em: 25/04/2014.
} 
despejados acidentalmente no canal de São Sebastião respectivamente 7.500 e 86.000 mil litros de óleo. ${ }^{7}$ Em 2002 outro vazamento de 3 mil litros de petróleo e, recentemente, em maio de 2013, mais um desastre ambiental que poluiu e interditou nove praias. Estes índices tendem a aumentar no litoral norte do estado de São Paulo e de forma mais desastrosa, principalmente com a construção do segundo píer no Terminal Marítimo Almirante Barroso - Tebar, o que significa maior bombeamento de petróleo para as refinarias e maior circulação de navios petroleiros na região. Sem falar na ampliação do Porto Comercial em São Sebastião e na Unidade de Tratamento de Gás em Caraguatatuba, responsáveis também por maior circulação de mercadorias e gás, o que ampliará proporcionalmente os riscos de acidentes ambientais mais significativos

A Petrobras, responsável pela exploração do petróleo e seus derivados, foi multada pelos acidentes causados, mas qual o verdadeiro dano no meio ambiente destes vazamentos a médio e longo prazo?

E a exploração da camada pré-sal? Temos tecnologia suficiente, equipes treinadas e à disposição para conter imediatamente possíveis vazamentos?

Poderíamos discutir se vale a pena explorar a camada brasileira do pré-sal nos dias de hoje, ou ainda, estimar qual a quantidade de petróleo poderia ser retirada e utilizada afim de manter o equilíbrio de emissão do $\mathrm{CO}^{2}$ ?

Por se tratar de uma energia "suja", finita e de grande risco ambiental em sua exploração, com efeitos incalculáveis caso acidentes ocorram, talvez neste momento uma alternativa seria ampliar as pesquisas e investir em energias limpas e sustentáveis, como a eólica, solar, energia das marés e biocombustível, até que existam tecnologias mais avançadas e equipes especializadas, tanto para sua exploração quanto para contenção de possíveis acidentes. Os estudos de impactos ambientais ainda teriam tempo para aperfeiçoamentos e evolução no entendimento dos diversos riscos negativos ao meio ambiente e nas contrapartidas necessárias.

Como vimos anteriormente, todo empreendimento considerado de significativo potencial de degradação ou poluição está sujeito ao processo de licenciamento, e caso acidentes ambientais ocorram, tais como vazamento de óleo e petróleo por exemplo, o dano na maioria das vezes é perceptível visualmente.

Mas e a percepção em relação aos danos urbanos, reflexo dos grandes empreendimentos instalados na região, que podem ocorrer apenas a médio e longo prazo, como falta de infraestrutura, de moradia, de transporte e de mobilidade, falta de emprego qualificado, aumento da violência, poluição do ar e da água, entre outros problemas?

E os demais empreendimentos que não necessitam de estudos ambientais mas que serão atraídos pelos grandes empreendimentos licenciados?

\footnotetext{
7 Disponível em: <http://ambientes.ambientebrasil.com.br/energia/acidentes_ambientais/principais_acidentes_com_ petroleo_e_derivados_no_brasil.html>. Acesso em: 29/09/2014.
} 
Como e quem responsabilizar? Um ônus apenas para o poder público e sua população?

Mais uma corrida imobiliária responsável por trazer novas ofertas de empregos e maiores arrecadações de impostos municipais, mas, sem dúvida, responsável também pelo aumento dos congestionamentos, aumento da produção de lixo, aumento de favelas (migrações atraídas pelas oportunidades), maior pressão nas áreas protegidas, principalmente na Serra do Mar, falta de água e de tratamento de esgoto. Ou seja, falta entendimento técnico e científico para exigir investimentos antecipados em infraestrutura urbana compatível e suficiente para atender de forma satisfatória as novas demandas.

Uma das principais perguntas é se os atuais Estudos de Impactos Ambientais em andamento no Litoral Norte de São Paulo são suficientes para proporcionar sustentabilidade urbana.

A tese deste trabalho é apresentar a existência de fortes evidências de que os EIA-RIMA elaborados para o Litoral Norte de São Paulo são insuficientes enquanto busca de sustentabilidade urbana para a região, principalmente para a cidade de São Sebastião. 


\section{CAPÍTULO I}

Litoral Norte do Estado de São Paulo

A cidade de São Sebastião e sua transformação urbana 
1. LITORAL NORTE DO ESTADO DE SÃO PAULO

\section{1 - A cidade de São Sebastião}

s condições geográficas do litoral brasileiro, sobretudo as facilidades das interfaces do territóções privilegiadas para navegação e defesa militar, características decisivas na escolha dos primeiros assentamentos, que estiveram sempre vinculados aos diversos ciclos econômicos nacionais, acabaram por consolidar zonas portuárias. É o caso do Porto de São Sebastião, localizado no Litoral Norte do estado de São Paulo, entre as duas maiores cidades do Brasil, São Paulo e Rio de Janeiro.

A região era inicialmente ocupada por índios até a chegada dos portugueses em 1532, liderados por Martins Afonso de Souza, com interessa na exploração da madeira e em um segundo momento na produção de cana-de-açúcar, principalmente para abastecer o mercado europeu.

A cidade prospera (Figura 2) com a instalação de uma estrutura para pesca de baleia e a a abertura de fábricas de seus derivados, além da expansão da produção de açúcar e aguardente. Com a implantação da ferrovia no planalto (1817) e a abolição da escravatura (1889), o interesse comercial pelo Porto de São Sebastião diminui.

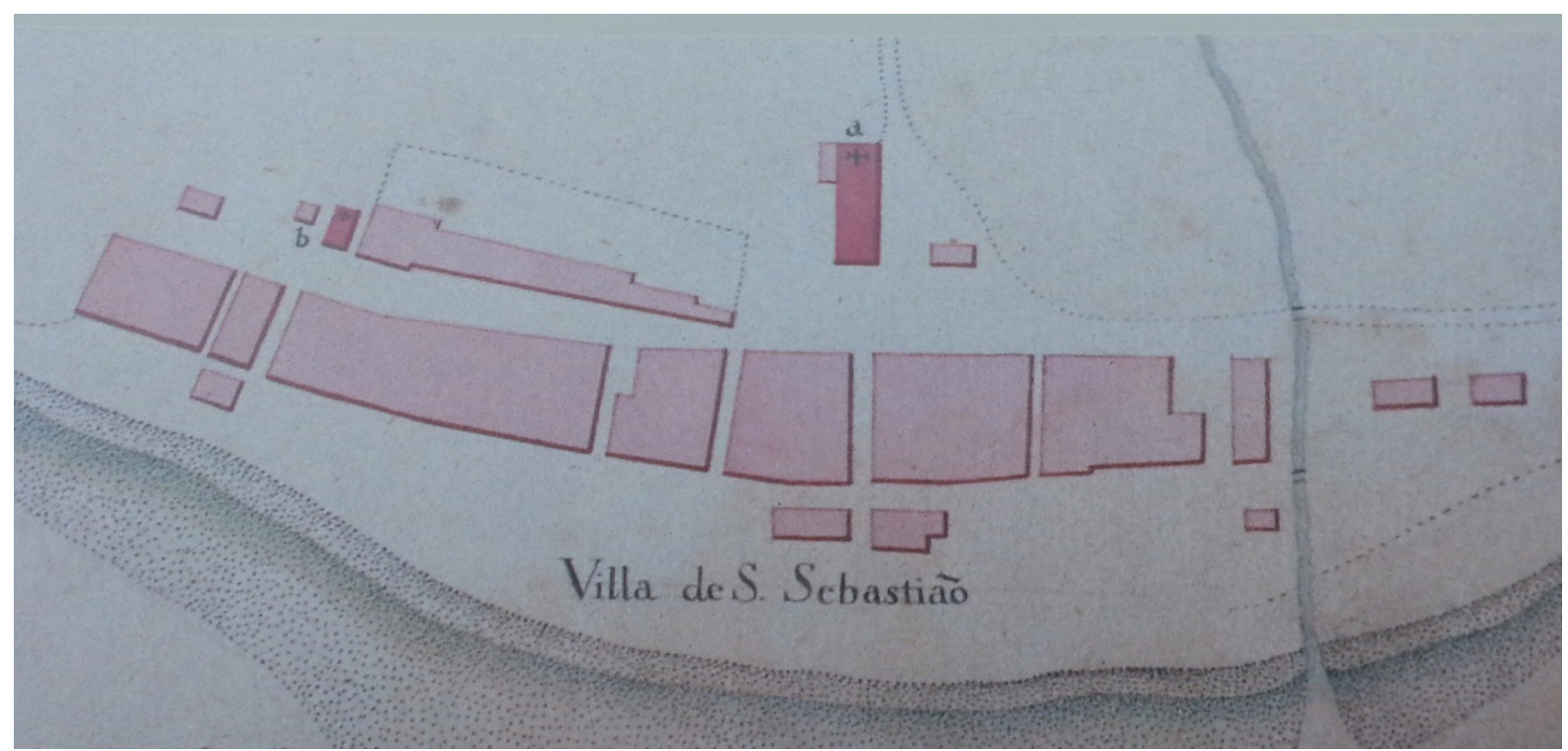

Fonte: Imagens de Vilas e Cidades do Brasil Colonial, Nestor Goulart Reis (2001).

Figura 2 - Vila de São Sebastião em 1815 
Só no início do século XIX, com a expansão da cafeicultura, o porto passa novamente a ser utilizado como escoamento da produção de café produzido ao norte de São Paulo e ao sul de Minas Gerais, com destino a cidade de Santos e Rio de Janeiro.

Manteve-se como entreposto comercial até 1920, quando se transformou em porto público. Em 1929 inicia-se a construção de um porto moderno como apoio e complementação ao Porto de Santos. A partir de 1932, com a melhoria do acesso viário ao Vale do Paraíba, o porto amplia sua importância regional e já apresentava propostas para sua ampliação em 1940, conforme Figura 3.

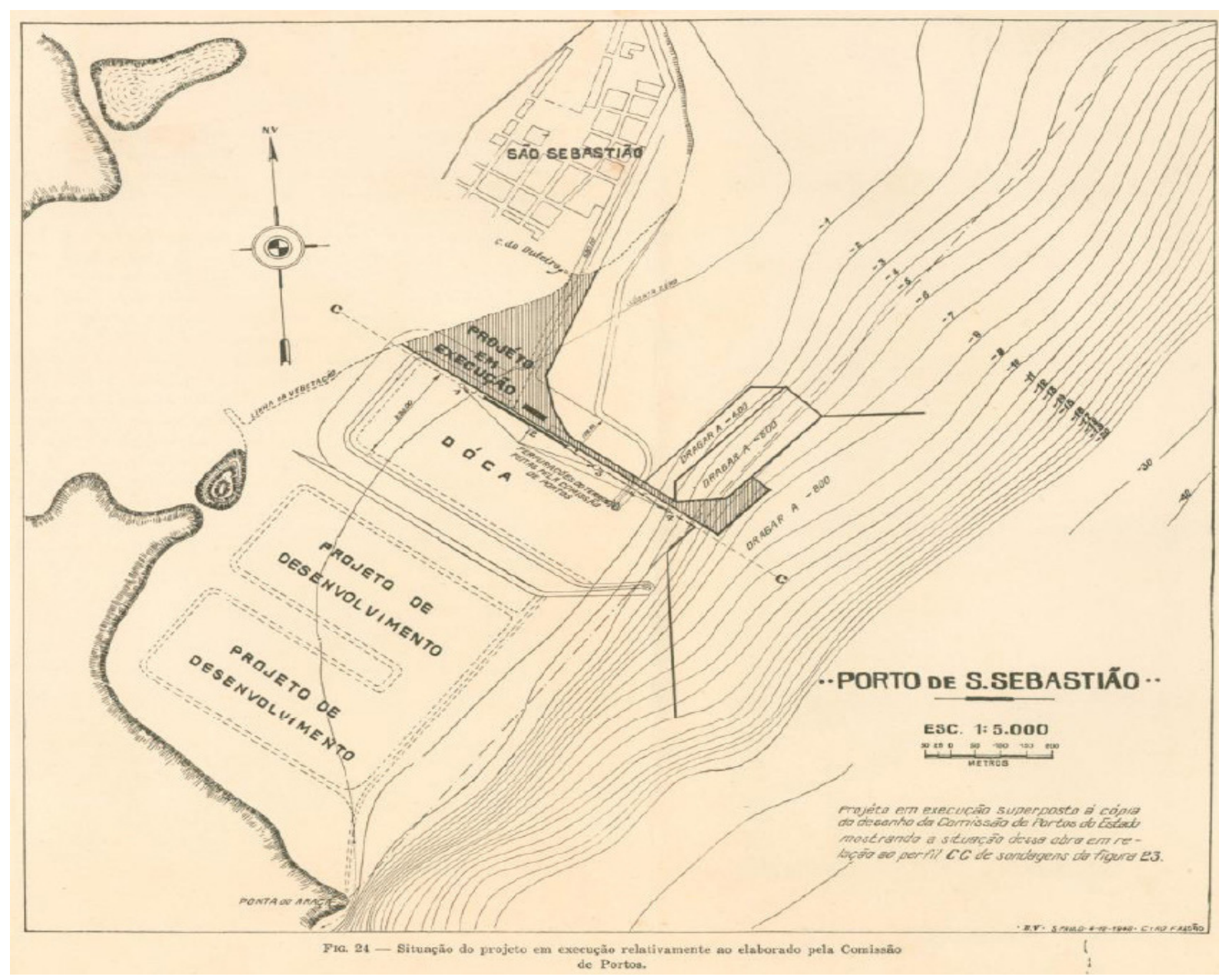

Fonte: Diretoria de Viação - CPEA (1940)

Figura 3 - Projeto de 1940 para ampliação do Porto de São Sebastião

A inauguração oficial do porto comercial ocorreu em 1955. A partir de 1961 inicia-se as obras do Terminal Marítimo Almirante Barroso - Tebar, da Petrobras, e a construção dos dutos de ligação para transporte de combustível até as cidades de Santos, Cubatão, Paulínia e Capuava. 
Outro fator importante para compreensão do modelo de ocupação deste território é o sistema de mobilidade na região, facilitados a partir da década de 1970 com investimentos em novas rodovias, ${ }^{8}$ e que desencadearam grande interesse imobiliário, principalmente para construção das residências de veraneio.

Por falta de planejamento iniciou-se um processo de valorização, ocupação predatória e irregular do solo, migração acelerada, distanciamento sócio espacial e degradação ambiental, aprofundando o conflito de interesse entre os agentes sociais (setor imobiliário, proprietários dos meios de produção, proprietários fundiários, Estado e grupos sociais).

A privilegiada configuração natural deste território (Figura 4), é responsável pela evidente disputa pelo espaço, preferencialmente pela orla marítima, ocupada por casas de alto padrão e consequentemente favelas nas encostas da Serra do Mar.

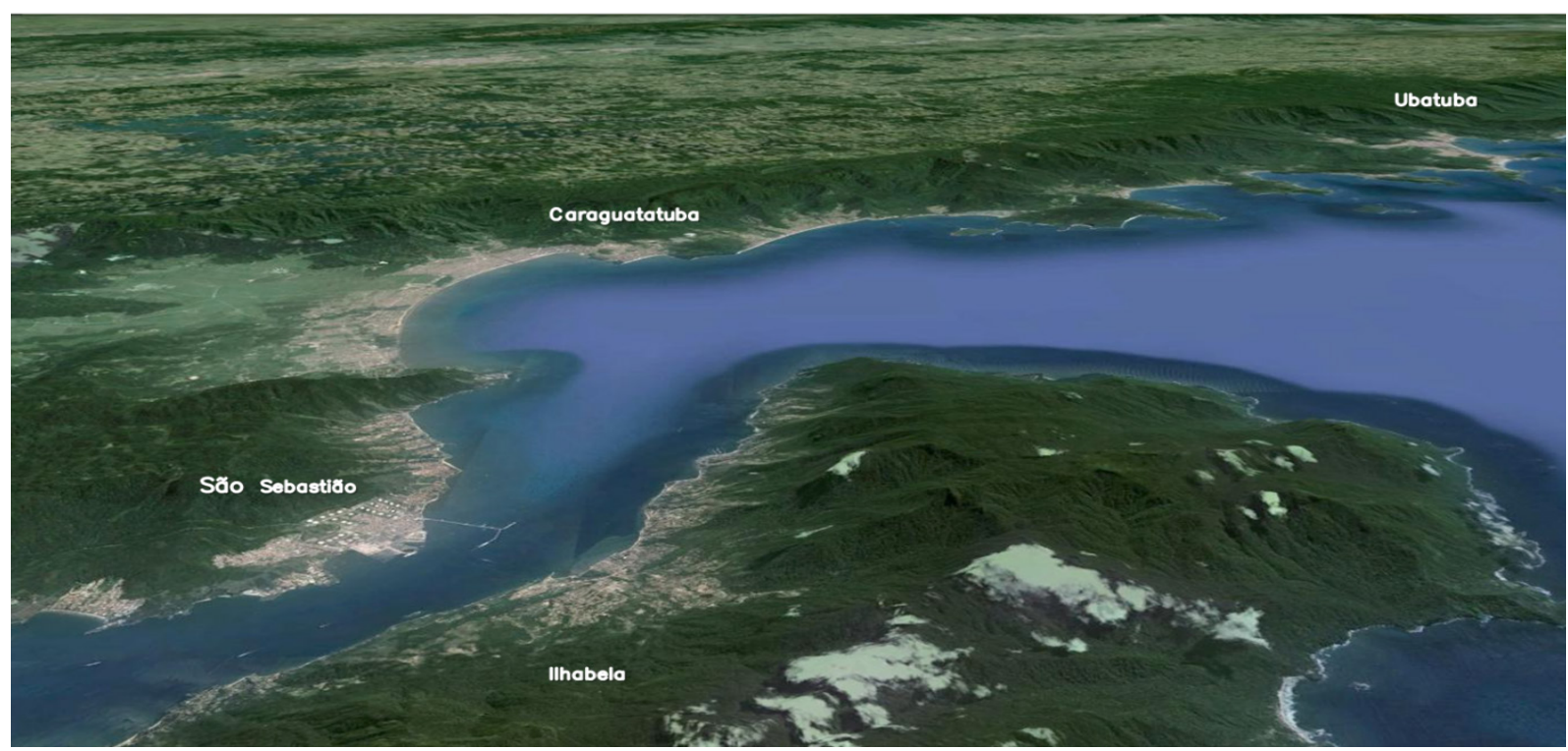

Fonte: Google Earth (2013).

Figura 4 - São Sebastião, Ilhabela, Caraguatatuba e Ubatuba. Municípios que compõe o Litoral Norte do estado de São Paulo

A região é composta pelos municípios de Ubatuba, Caraguatatuba, São Sebastião e Ilhabela, que apresentam todos os problemas de uma ocupação acelerada ${ }^{9}$ em um território ambientalmente frágil,

\footnotetext{
${ }^{8}$ As principais rodovias construídas a partir da década de 1970 e que facilitaram o acesso ao litoral norte do estado de São Paulo foram a SP-055 - Dr. Manoel Hypólito Rego (Santos - São Sebastião), SP-098 - Dom Paulo Rolim Loureiro (Mogi das Cruzes - Bertioga), SP-099 - Rodovia dos Tamoios (S. José dos Campos - Caraguatatuba), SP-070 -Sistema Trabalhadores (São Paulo - Taubaté), SP-065 - Dom Pedro I (Jacareí - Campinas) e a BR-116 - Presidente Dutra/ Nova Dutra (São Paulo - Rio de Janeiro).

${ }^{9}$ O município de Caraguatatuba foi considerada em 2013, e pelo terceiro ano consecutivo, a cidade mais violenta do estado de São Paulo, com taxa de 28,3 homicídios por 100 mil habitantes, ou quase o triplo do índice de todo o estado. Foram considerados 76 municípios com mais de 100 mil habitantes para este estudo. Fonte: IBGE (Instituto Brasileiro de Geografia e Estatística) e SSP-SP (Secretaria da Segurança Pública do Estado de São Paulo).
} 
localizado em uma estreita faixa litorânea, restrita pela Serra do Mar e pelo Oceano Atlântico. É uma das regióes que mais cresceu no estado de São Paulo entre os anos de 2011 e 2013, segundo dados da fundação SEADE (Sistema Estadual de Análise de Dados). Um território com grande e crescente interesse econômico (Figura 5), pouco pensado de maneira conjunta para um desenvolvimento mais sustentável na escala regional.
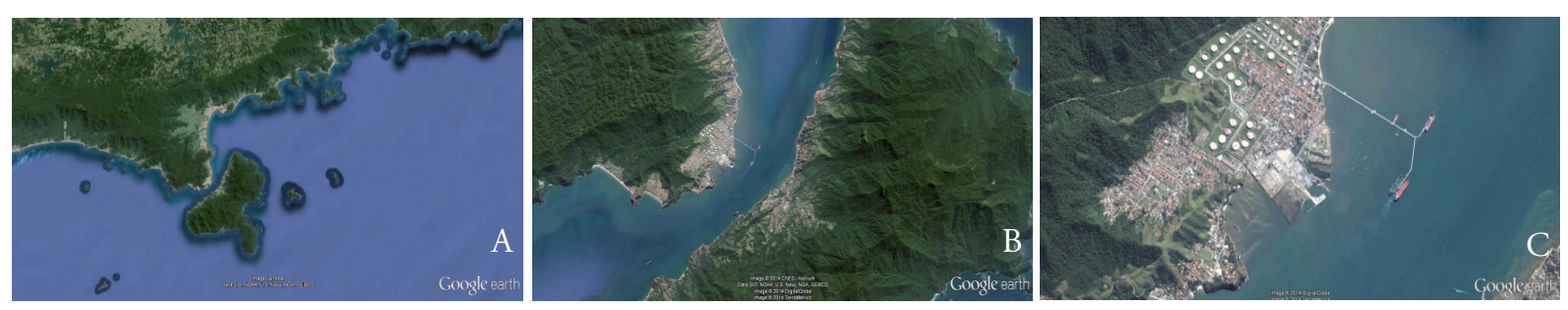

Fonte: Google Earth (2014).

Figura 5 - Vista aérea do Litoral Norte de São Paulo

A - Litoral Norte do estado de SP

B - Canal de São Sebastião

C - Cidade de São Sebastião

A região está prestes a entrar em um novo ciclo econômico, principalmente com a exploração da camada pré-sal na bacia de Santos, a ampliação do píer petroleiro do terminal aquaviário e a ampliação do porto comercial de São Sebastião, que em 2013 movimentou 800 mil toneladas e pretende passar a 25 milhões de toneladas até o ano de 2030.

Os sistemas de acessos rodoviários também estão sendo ampliados, com a duplicação da rodovia dos Tamoios no trecho Planalto e Serra do Mar, ${ }^{10}$ além das novas rodovias denominadas Contorno Norte (conexão da rodovia dos Tamoios com o município de Caraguatatuba) e o Contorno Sul (conexão da rodovia dos Tamoios com o município de São Sebastião e porto comercial).

A SP-055, rodovia Dr. Manoel Hyppolito do Rego, mais conhecida como Rio-Santos (BR-101), no trecho que vai de Santos, passando por Bertioga, São Sebastião, Caraguatatuba e Ubatuba, que apresenta congestionamentos frequentes, também será ampliada. Mais uma obra necessária, mas que deverá ser discutida não só por atravessar o Parque Estadual da Serra do Mar, com provável desmatamento da Mata Atlântica em muitos trechos, mas principalmente pelo grande impacto com o maior fluxo de turistas na região, o que sobrecarregará a infraestrutura existente e faltará sem dúvida investimentos para atender as novas demandas (Figura 6).

\footnotetext{
${ }^{10}$ Duplicação do trecho Planalto (SP-099) da rodovia dos Tamoios foi a primeira etapa de sua duplicação, com o custo de R \$ 672,4 milhões, entregue em 24/01/2014. O segundo trecho é o da Serra do Mar, orçada em R \$ 2,1 bilhōes, a ser custeada em parceria com a iniciativa privada, que em contrapartida instalará três praças de pedágio. Disponível em: <http://g1.globo.com/sp/vale-do-paraiba-regiao/noticia/2014/01/sp-entrega-duplicacao-do-trecho-de-planalto-da-rodovia-dos-tamoios.html>. Acesso em: 20/01/2014.
} 


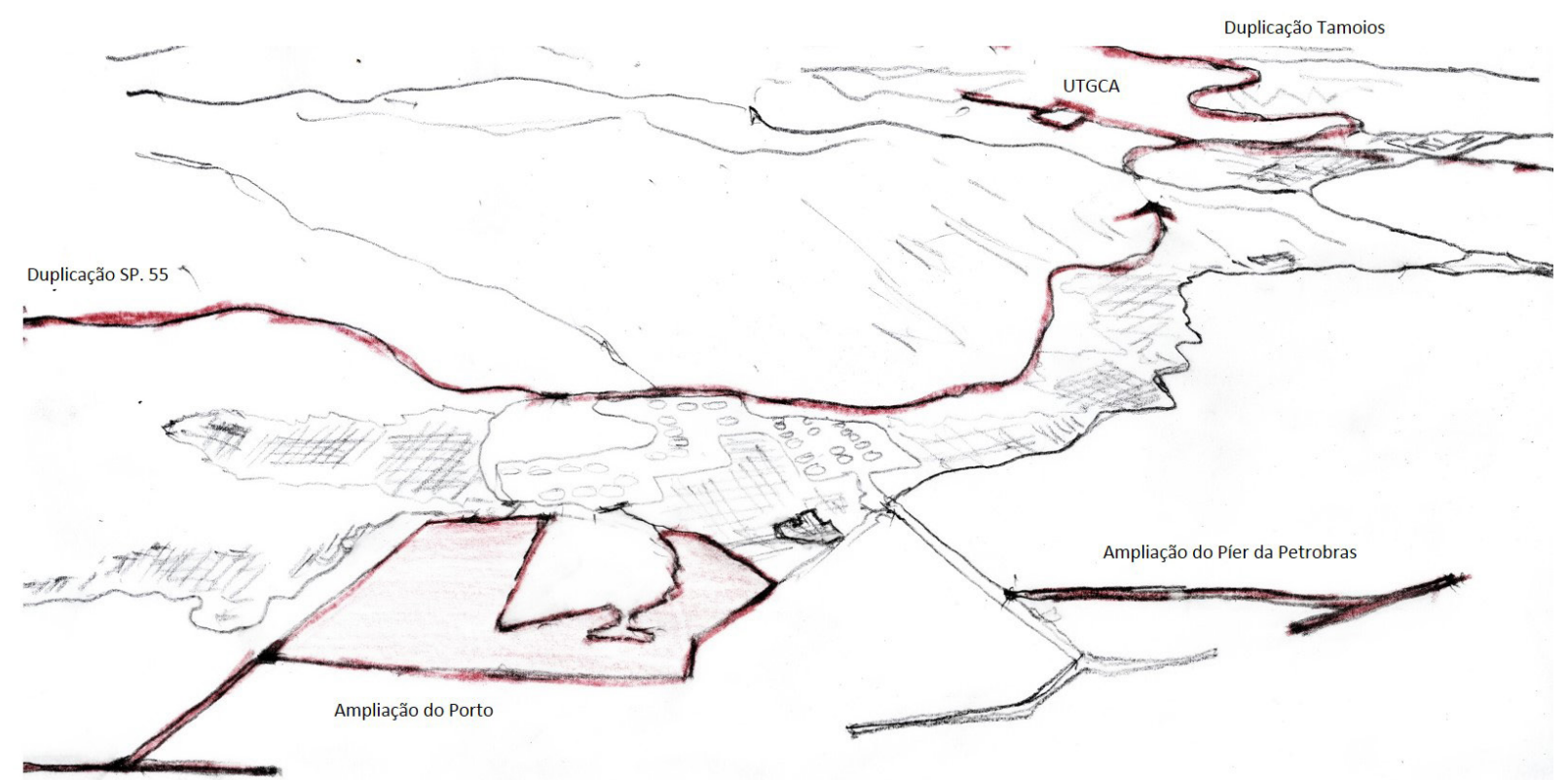

Fonte: José Francisco Xavier Magalhães (2014).

Figura 6 - Litoral Norte do Estado de São Paulo

Em vermelho os grandes empreendimentos em processo de licenciamento, como a ampliação do Porto Comercial e o novo píer da Petrobras, duplicação da SP-055, obras iniciadas da duplicação da rodovia dos Tamoios, Contornos Sul e Norte e, já em funcionamento, a Unidade de Tratamento de Gás, na cidade de Caraguatatuba.

Segundo o IBGE (Instituto Brasileiro de Geografia e Estatística), a população também vem crescendo em um ritmo acelerado no Litoral Norte, principalmente na cidade de Caraguatatuba e São Sebastião, muito em função das expectativas relacionadas aos diversos empreendimentos em andamento na região, mas principalmente pela ampliação do porto e exploração da camada pré-sal.

\begin{tabular}{|lc|c|c|}
\hline \multicolumn{1}{|c|}{ Município } & População ano 2010 & População ano 2014 & Área $\mathbf{k m}^{2}$ \\
\hline Caraguatatuba & 100.840 & 111.524 & 485,097 \\
\hline Ubatuba & 78.801 & 85.399 & 723,883 \\
\hline São Sebastião & 73.942 & 81.718 & 399,679 \\
\hline Ilhabela & 28.196 & 31.599 & 347,515 \\
\hline
\end{tabular}

Fonte: IBGE (2014).

Tabela 1 - População estimada - ano de 2014

São Sebastião, Caraguatatuba, Ubatuba e Ilhabela, segundo a Fundação SEADE (Sistema Estadual de Análise de Dados), foram as quatro cidades que mais cresceram no estado de São Paulo nos anos de 2011, 2012 e 2013, com índices superiores a 4\% ao ano.

A Sabesp (Companhia de Saneamento Básico do Estado de São Paulo) também confirma que as cidades de São Sebastião e Ilhabela são as que mais crescem no Estado na última década, mas ao 
mesmo tempo apresentam problemas no tratamento de esgotos. São Sebastião trata apenas 30\% de seu esgoto e Ilhabela trata apenas $4 \%$.

No fim de 2007 a Sabesp já falava em investimentos de R 2 bilhões para a região, que teoricamente elevaria, por meio de um programa denominado "Onda Limpa", o índice de coleta e tratamento de esgoto para 80\% até 2011. Atualmente, o Governo do Estado de São Paulo informa que vai elevar a coleta e tratamento de esgotos do Litoral Norte para $85 \%$ e que o programa "Onda Limpa" prevê investimentos de cerca de R \$ 1,5 bilhão na Região Metropolitana da Baixada Santista e Litoral Norte de São Paulo, mas na realidade o que vemos é o aumento do número de praias classificadas como impróprias para banho pela Companhia Ambiental do Estado de São Paulo (CETESB).

Qual o verdadeiro impacto e que tipo de "desenvolvimento" os atuais projetos para o Litoral Norte do estado de São Paulo poderão desencadear na região?

Os grandes empreendimentos em processo de licenciamento buscam viabilizar suas obras de forma pouco ou nada integrada, tanto com os demais projetos em licenciamento quanto com a cidade existente.

O resultado será uma junção de diversos empreendimentos construídos de forma simultânea e que em nenhum momento foram pesados, analisados 3 desenhados de maneira conjunta. Há fortes indícios que o aparente desenvolvimento proclamado pelos diversos EIA-RIMA destes empreendimentos será um extraordinário retrocesso ambiental e urbano, com grande impacto negativo na região a curto e médio prazo.

A cidade de São Sebastião possui um importante centro histórico, datado do século XVIII, com sete quarteirões tombados pelo Condephaat (Conselho de Defesa do Patrimônio Histórico, Artístico, Arqueológico e Turístico do Estado de São Paulo), com construções consideradas importantíssimas, como a Capela de São Gonçalo, Igreja Matriz, Casa de Câmara e Cadeia e a Casa Esperança, tombada pelo Patrimônio Histórico Nacional (Figura 7).

Na década de 1980 foi autorizado e construído um grande aterro em frente a este patrimônio, conforme veremos no capítulo 3 deste trabalho, o que comprometeu a histórica proximidade do mar ao centro histórico da cidade de São Sebastião, além do grande impacto negativo na paisagem. Veremos que esta obra obteve licença ambiental e foi justificado pelo EIA-RIMA encomendado pela Petrobras como uma grande oportunidade de expansão urbana para a cidade (Figura 8).

Poderíamos afirmar que o instrumento EIA-RIMA já demostrou sua ineficiência enquanto busca de sustentabilidade urbana na cidade de São Sebastião. O aterro ficou por mais de duas décadas abandonado e agora um novo EIA-RIMA para ampliação do porto justifica novamente os benefícios positivos econômicos e sociais para a cidade, com exigências mínimas para mitigar ou compensar os impactos negativos (Figura 9). 


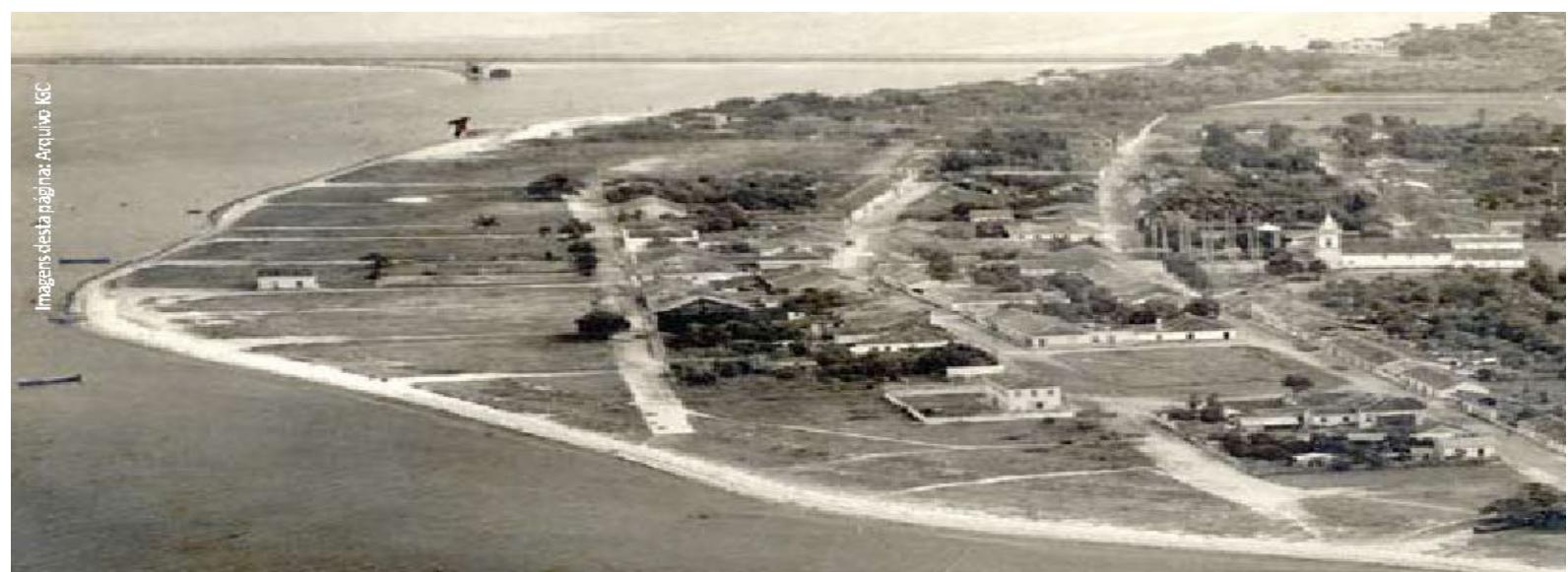

Fonte: Plano Integrado Porto Cidade, PIPC São Sebastião - SP outubro 2009.

Figura 7 - Frente de Marítima da cidade de São Sebastião - Século XIX

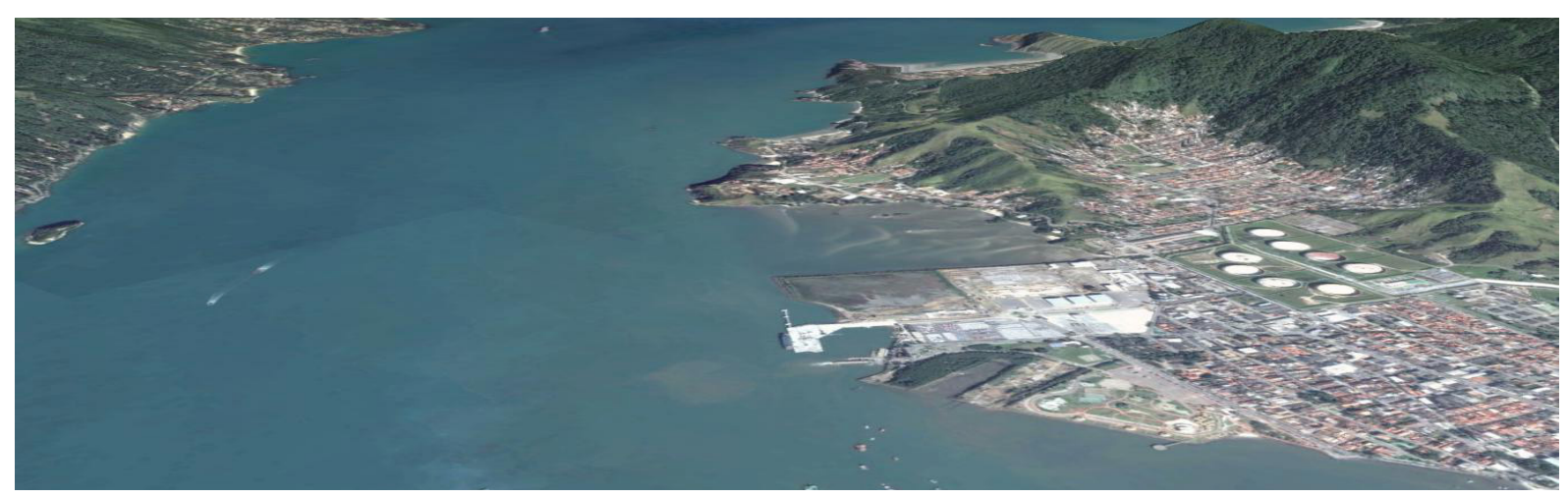

Fonte: Google Earth (2014).

Figura 8 - Frente de Marítima da cidade de São Sebastião, 2014

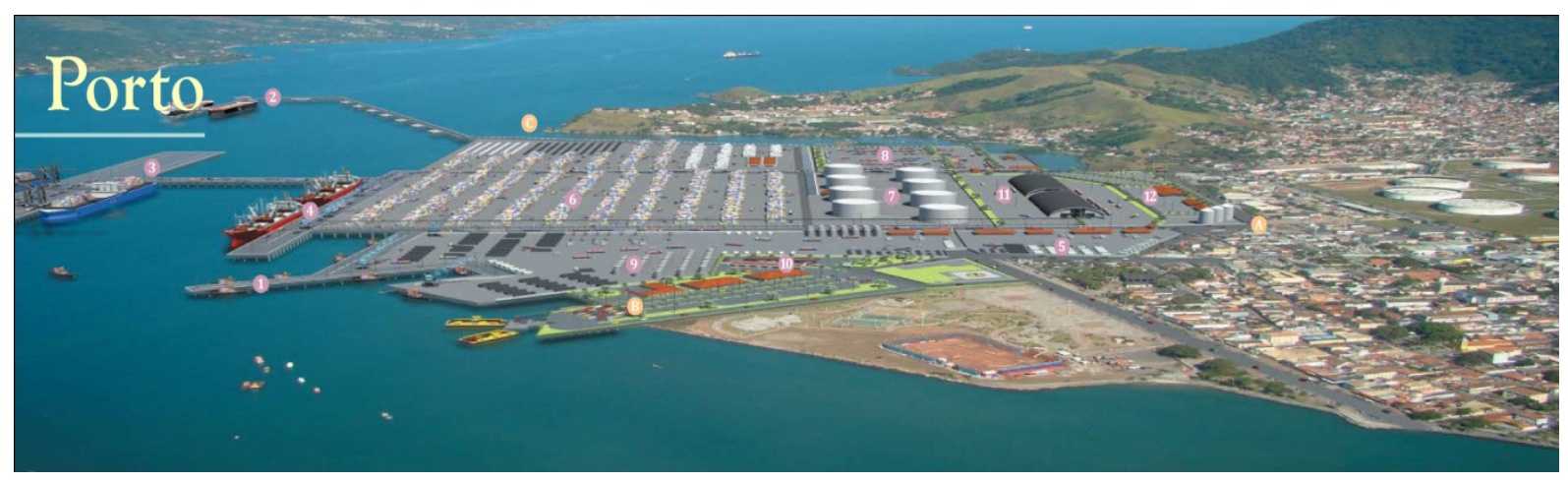

Fonte: Plano Integrado Porto Cidade, PIPC São Sebastião - SP outubro 2009.

Figura 9 - Projeto de ampliação do Porto Comercial - São Sebastião 


\section{CAPÍTULO II}

\section{ZONAS PORTUÁRIAS}

0 caso do Porto de São Sebastião no Litoral Norte do estado de São Paulo 


\subsection{Portos comercias}

$\Lambda_{\text {tância na evolução das civilizações. Um local de grande centralidade, responsável pelas cone- }}$ xões comerciais entre os diversos povos, utilizando principalmente as embarcações como veículo de transporte.

No Brasil, a maior parte desses locais foram escolhidos, historicamente, em razão das condições geográficas privilegiadas dos portos naturais, existentes ao longo da costa, tanto para a defesa do território quanto para a navegação. Estas características eram os aspectos fundamentais na segurança das operações de embarque e desembarque, viabilizando os transportes de mercadorias, responsáveis pela consolidação destas áreas como zonas portuárias, que evoluíram associadas às principais funções urbanas. O porto era o motor de seu desenvolvimento econômico, o centro urbano e estruturante dessas cidades.

Com o crescimento das atividades portuárias e a necessidade da maior abertura internacional para integrar o sistema de distribuição em rede, os portos precisaram ampliar suas áreas, principalmente para estocagem (recentemente em mercadorias transportadas dentro de contêineres), os retroportos.

Os portos passaram a agregar cada vez mais áreas às suas instalaçóes, fazendo com que a maioria dos centros urbanos perdessem o contato com suas frentes marítimas ou fluviais. Inicia-se então a degradação do seu entorno imediato, resultado em grande parte das mudanças nos sistemas de transporte marítimo, comprometendo a qualidade de vida nestes locais. O porto deixa de cumprir o seu papel histórico na promoção e na contribuição do desenvolvimento urbano das regióes onde estão inseridos, passando a se comportar como territórios internacionais, desconectados das suas cidades e regidos por leis próprias.

Algumas zonas portuárias, localizadas em centros urbanos importantes, começaram a sofrer pressões tanto do poder público quanto da própria população, que percebendo o valor destas áreas buscaram formas para reintegrá-las novamente ao tecido urbano, como o Puerto Madeiro em Buenos Aires, na Argentina.

O centro histórico da cidade de Buenos Aires (Plaza de Mayo) perdeu sua relação direta com o rio da Prata no final do século XIX com a ampliação do porto comercial (Puerto Madeiro). 
No final dos anos 1970 outra intervenção agravou ainda mais o distanciamento da cidade com sua frente fluvial. O local foi utilizado como "bota-fora" (Figura 10) de entulhos, resultado das muitas demolições necessárias para a construção de novas avenidas costeiras.

O objetivo para o aterro, com aproximadamente 350 ha, era a expansão urbana do centro de Buenos Aires, o que acabou não ocorrendo. Com o seu abandono a natureza iniciou um processo natural de regeneração da fauna e flora, o que justificou transformá-la mais tarde em uma reserva ecológica, denominada reserva ecológica Costanera Sur (Figura 11).

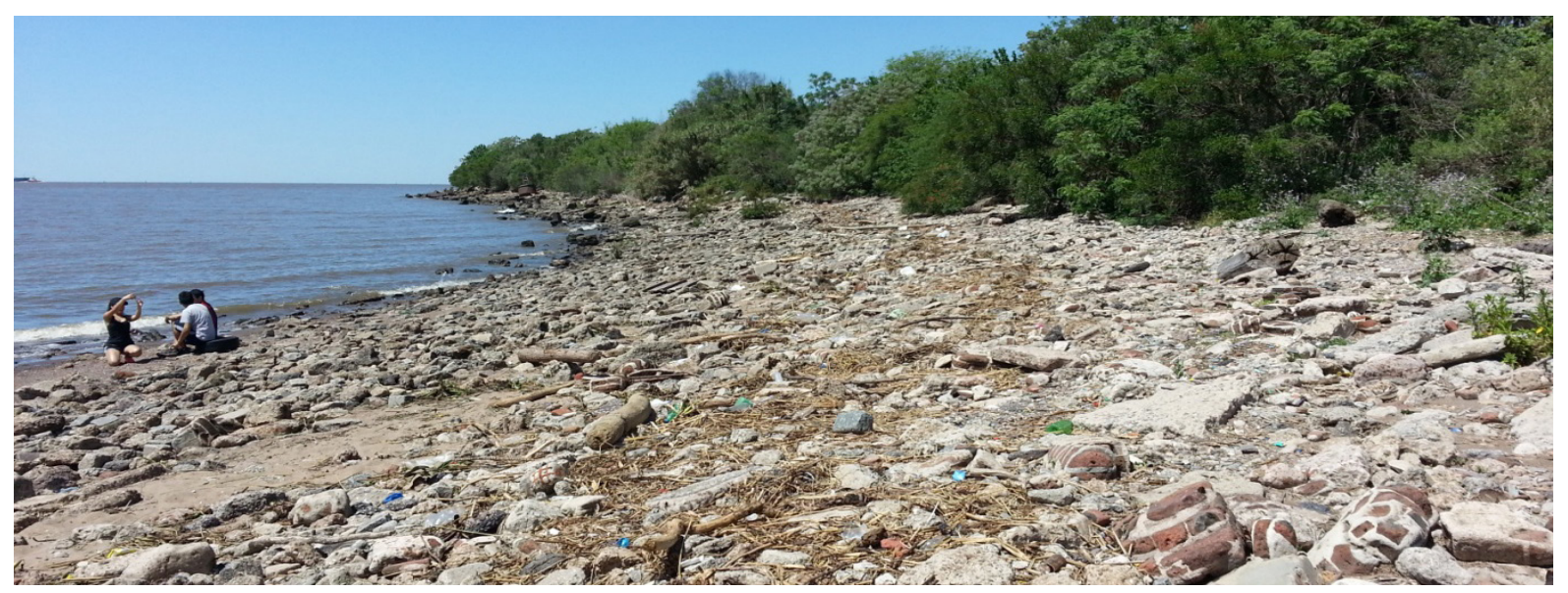

Fonte: José Francisco Xavier Magalhães (2014).

Figura 10 - Frente fluvial da cidade Buenos Aires. Bota-fora, 2014

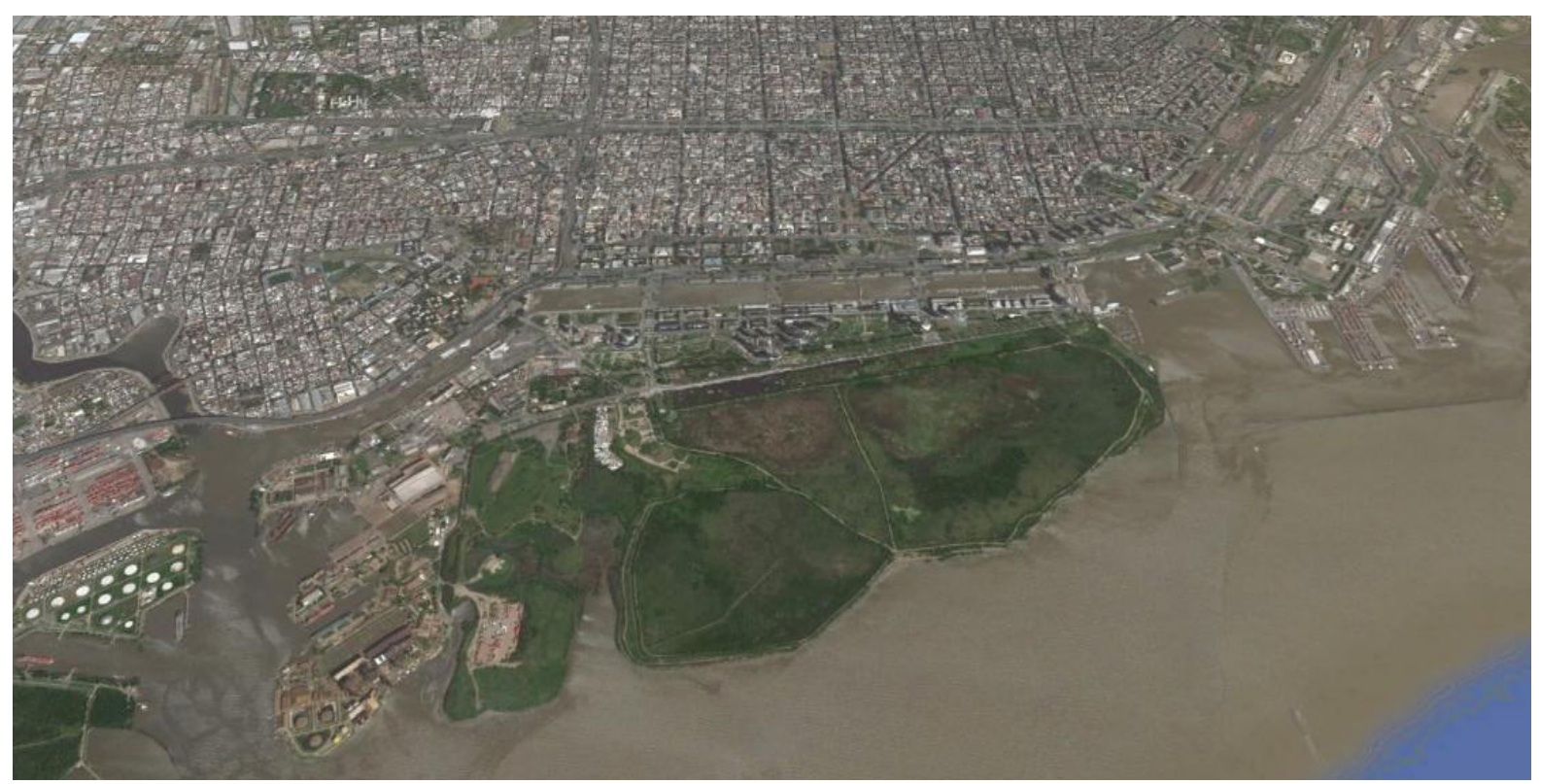

Fonte: Google Earth (2014).

Figura 11 - Frente Fluvial da cidade Buenos Aires interrompida pelo Puerto Madeiro e pelo aterro, 2014 
Outros exemplos, como o porto comercial de Barcelona, na Espanha (figura12), Docklands, em Londres (Figura13), e mais recentemente as revitalizaçôes brasileiras, como o Porto Maravilha, no Rio de Janeiro (Figura14), indicam os esforços para reverter e integrar novamente estes setores no tecido urbano da cidade.

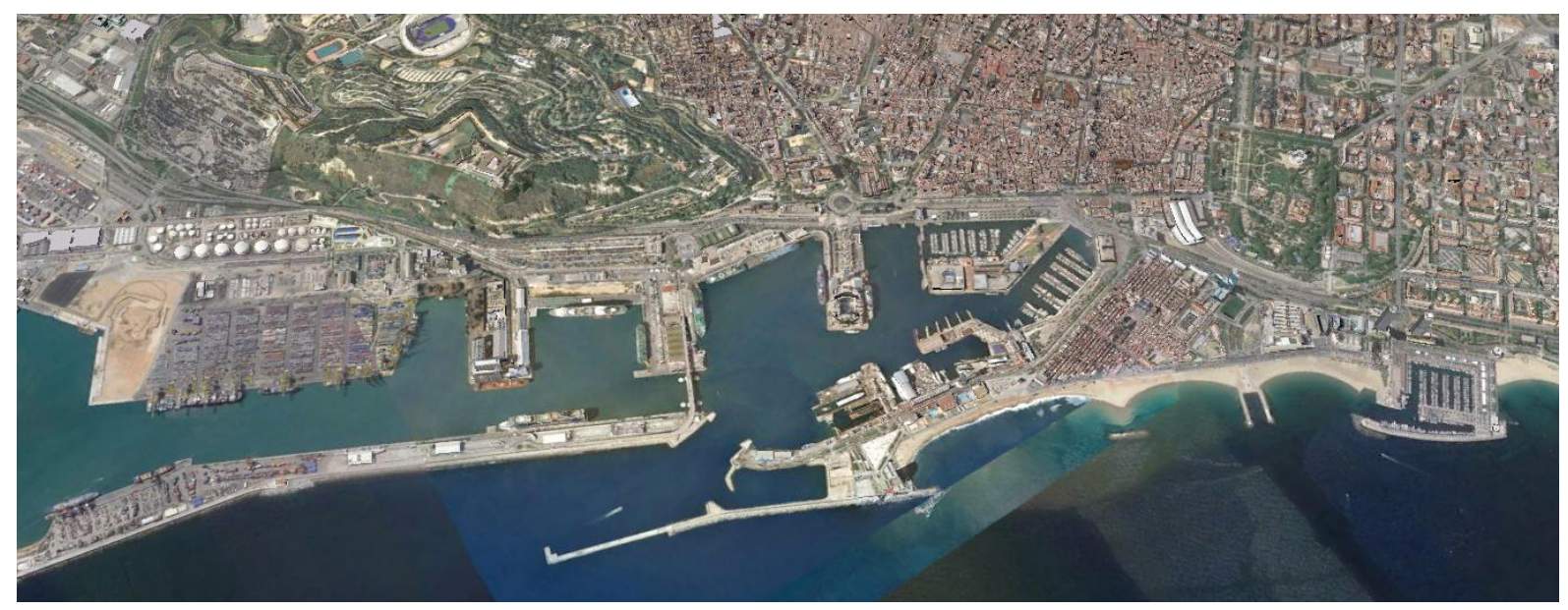

Fonte: Google Earth (2014).

Figura 12 - Frente Marítima da cidade de Barcelona, 2014

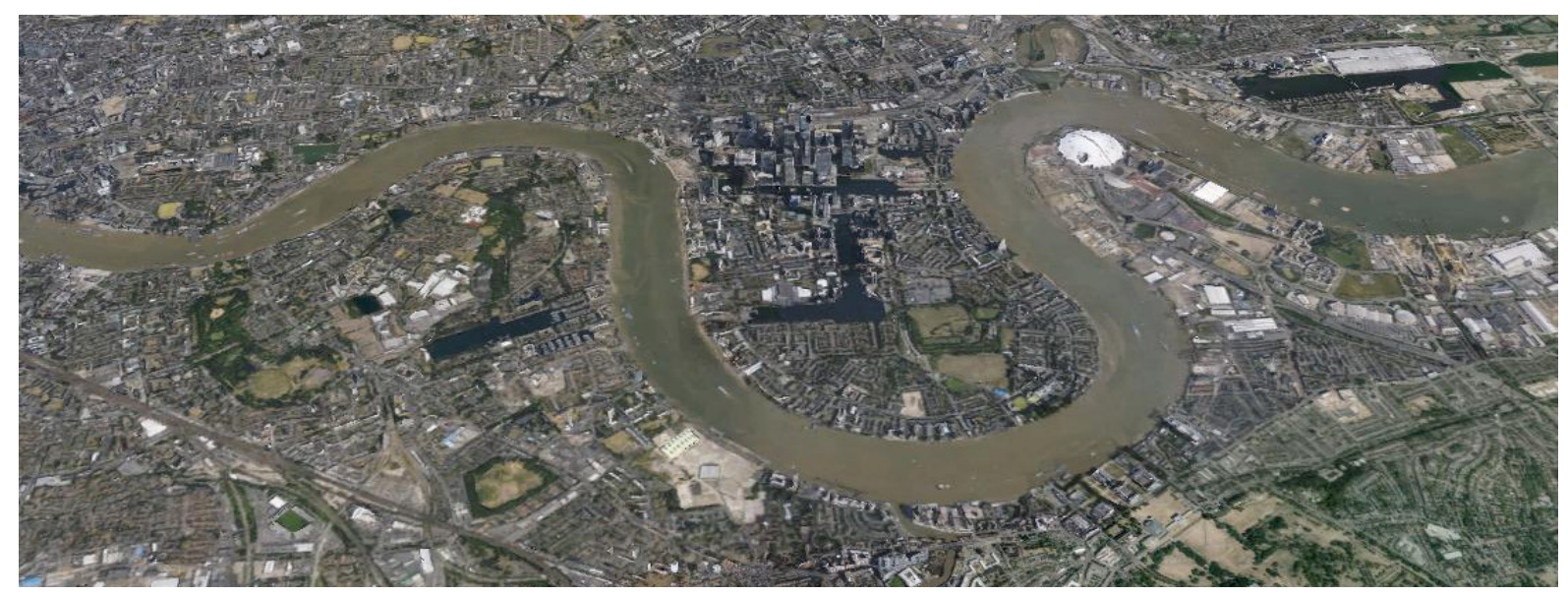

Fonte: Google Earth (2014).

Figura 13 - Docklands, Londres, 2014

As evoluções técnicas nas atividades portuárias, o seu novo dinamismo nos sistemas de transportes, os aspectos ambientais, as novas legislações, entre outras ações, podem ser as oportunidades para que os portos recuperem a possibilidade de contribuir nas questôes urbanas de suas cidades, como, por exemplo, na devolução de áreas centrais para atualização de seus usos, sobretudo em benefício e prioridade da coletividade. Para isso, são fundamentais as negociações entre poder público, iniciativa privada, autoridades portuárias e participação efetiva da sociedade organizada em direção a estes objetivos. 


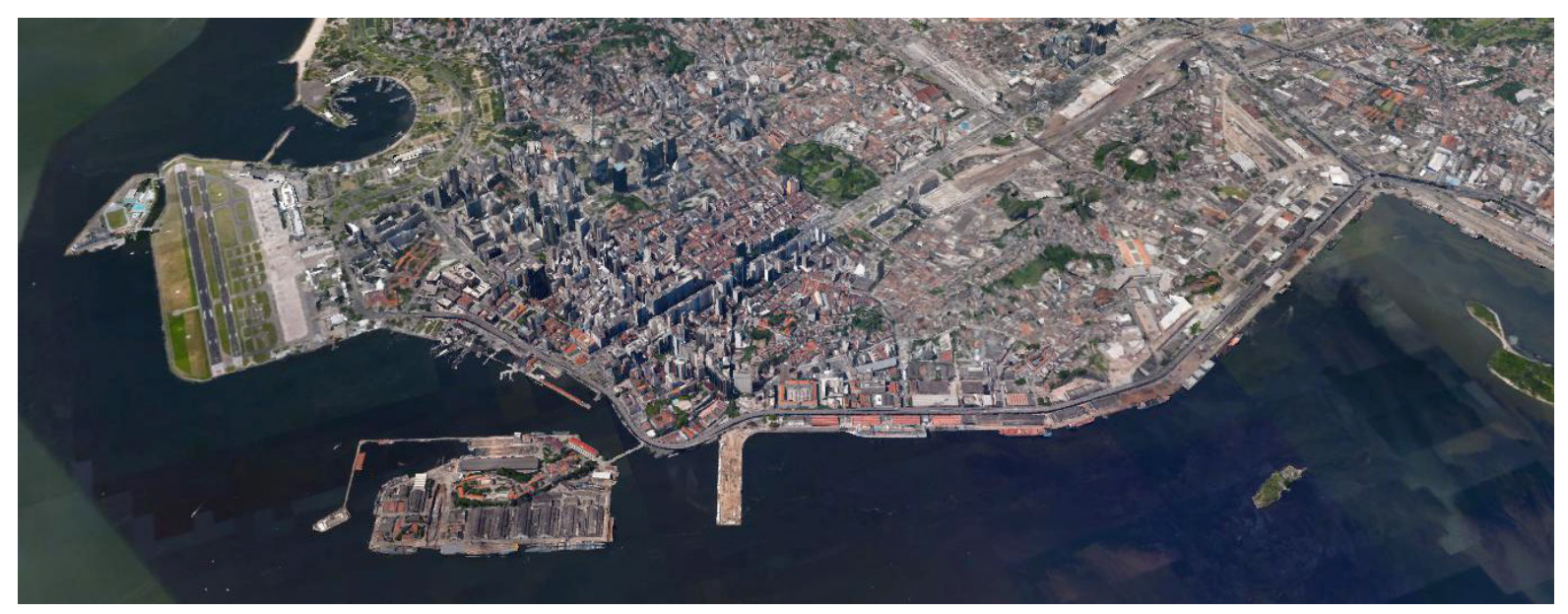

Fonte: Google Earth (2014).

Figura 14 - Porto Maravilha, cidade do Rio de Janeiro, 2014

\subsection{Centro histórico de São Sebastião cada vez mais distante da orla marítima.}

$\mathrm{E}$ nquanto na maioria dos portos comerciais do mundo existe uma política de recuperação e devolução de áreas portuárias para a cidade, com a revitalização de seus centros históricos, a cidade de São Sebastião está na direção contraria, ou seja, o porto comercial mantém esforços para ampliar seus domínios sobre áreas ambientalmente protegidas muito próximas ao centro histórico sem nenhuma preocupação urbana. Um projeto que não prevê setores de amortecimentos entre o porto e a cidade e que deixará esta última ainda mais confinada entre as instalaçôes da Petrobras, o porto com sua ampliação ${ }^{11}$ e o limite natural da Serra do Mar, patrimônio a ser preservado.

Caso os planos diretores das cidades do Litoral Norte não cumpram o seu papel de instruir o ordenamento territorial, dentro de uma perspectiva realmente sustentável e com preocupação regional, os interesses privados, apesar das legislações ambientais (Constituição Federal no Capítulo VI, Art.225, ${ }^{12}$ Lei Florestal no $12.651,{ }^{13}$ resolução Conama 001/86,,${ }^{14}$ lei Orgânica do Município de

\footnotetext{
${ }^{11}$ Atualmente não existem espaços para o estoque de contêineres, condição fundamental para viabilizar este tipo de carga.

${ }^{12}$ Constituição Federal no Capítulo VI, Art.225, de 1988. A zona costeira é considerada patrimônio nacional e só pode ser utilizada com a garantia de manter a qualidade do meio ambiente e dos recursos naturais, tendo como principais objetivos a preservação e restauração dos processos ecológicos essenciais, preservação da diversidade e integridade do patrimônio genético (fauna e flora).

${ }^{13}$ Código Florestal, lei no 12.651, de 25 de maio de 2012. Determina total preservação dos manguezais arbóreos em toda a sua extensão. Os manguezais são ecossistemas importantíssimos como berçário de grande parte da vida marinha, incluindo pescado de elevado valor econômico.

${ }^{14}$ Resolução do Conama 001/86 de 23 de Janeiro de 1986. Considera impacto ambiental qualquer alteração das propriedades físicas, químicas e biológicas do meio ambiente causada por qualquer forma de energia resultante das atividades humanas que afetam a saúde, a segurança, o bem-estar da população, as relações sociais e econômicas, as condições estéticas e sanitárias do meio ambiente e a qualidade dos recursos ambientais. Os EIA-RIMA devem seguir determinadas diretrizes para sua elaboração e entre elas contemplar alternativas tecnológicas e de localização do projeto, entender o efeito sinergético e cumulativo com outros projetos e obras em desenvolvimento na área de influência, analisando as
} 
São Sebastião, ${ }^{15}$ entre outras), encontrarão meios para viabilizar seus empreendimentos sem maiores preocupações com o bem comum.

A revisão do Plano Diretor da cidade de São Sebastião para o período de 2008 a 2012 incluiu a necessidade de viabilizar o retroporto ou retroárea, considerando o desenvolvimento e crescimento econômico da cidade, que segundo o Plano, estão diretamente relacionados com as atividades portuárias. O plano diretor cita que deverá haver garantias de proteção ambiental e preservação do centro histórico. Mas como e quais garantias? Quais são os projetos?

Outra oportunidade perdida para discutir qual o porto possível e mais adequado para a cidade de São Sebastião.

Todos os Estudos de Impacto Ambiental analisados nesta tese concluem ao final dos trabalhos que nenhum dos atuais projetos em licenciamento no Litoral Norte de São Paulo oferecem riscos que inviabilizam o empreendimento, e que as ações de mitigação e compensação ambiental serão suficientes para minimizar os impactos negativos.

É evidente que a ampliação do Porto de São Sebastião e demais empreendimentos serão responsáveis por algum desenvolvimento econômico e social, mas ao mesmo tempo responsáveis por diversos impactos negativos que não foram avaliados de maneira sinergética e cumulativa, o que trará evidentes riscos de descaracterização da paisagem litorânea e da acelerada degradação dos recursos naturais, principalmente com a ocupação dos espaços naturais pelos próprios empreendimentos e por pessoas atraídas pelas supostas oportunidades de empregos.

\subsection{Canal de São Sebastião, SP - hidrovia natural}

$\mathrm{O}$ Canal de São Sebastião desfruta de um monopólio ambiental pela característica do seu território e pela sua peculiaridade. Sua configuração de porto natural e com grandes profundidades despertam muitos interesses econômicos, principalmente da Petrobras e do porto comercial (Figura 15).

É um canal largo e profundo que não necessita de dragagem. Com 22,8 km de comprimento, de 2 a $7 \mathrm{~km}$ de largura e $40 \mathrm{~m}$ de profundidade em alguns pontos, composto por duas barras de entrada, Ponta das Canas ao norte (550 m de largura e profundidade de $18 \mathrm{~m}$ ) e Ponta das Selas ao sudoeste da ilha de São Sebastião (300 m de largura e profundidade de $25 \mathrm{~m}$ ).

possíveis interferências e, se for o caso, atestando pela inviabilidade do mesmo.

${ }^{15}$ Lei Orgânica do Município de São Sebastião. Estabelece em seu art. 151 que o canal de São Sebastião, a Mata Atlântica, a Serra do Mar, a Zona Costeira, as ilhas, as praias e os costões rochosos, os manguezais e as restingas são espaços territoriais especialmente protegidos e que sua utilização depende de prévia autorização que assegure a preservação do meio ambiente. 
Apresenta grande concentração de peixes, em especial na região do Araçá, com alta diversidade de espécies, local escolhido para ampliação do porto comercial. Golfinhos, botos e baleias podem ser vistos em diversas épocas do ano, o que indica alta qualidade do ambiente. Sua configuração natural o coloca como a terceira melhor região portuária do mundo, local onde foram instalados diversos equipamentos estruturantes, como o Porto Comercial de São Sebastião, o Terminal Almirante Barroso - Tebar, o Porto de Pesca e a balsa de conexão entre os municípios de São Sebastião e Ilhabela.

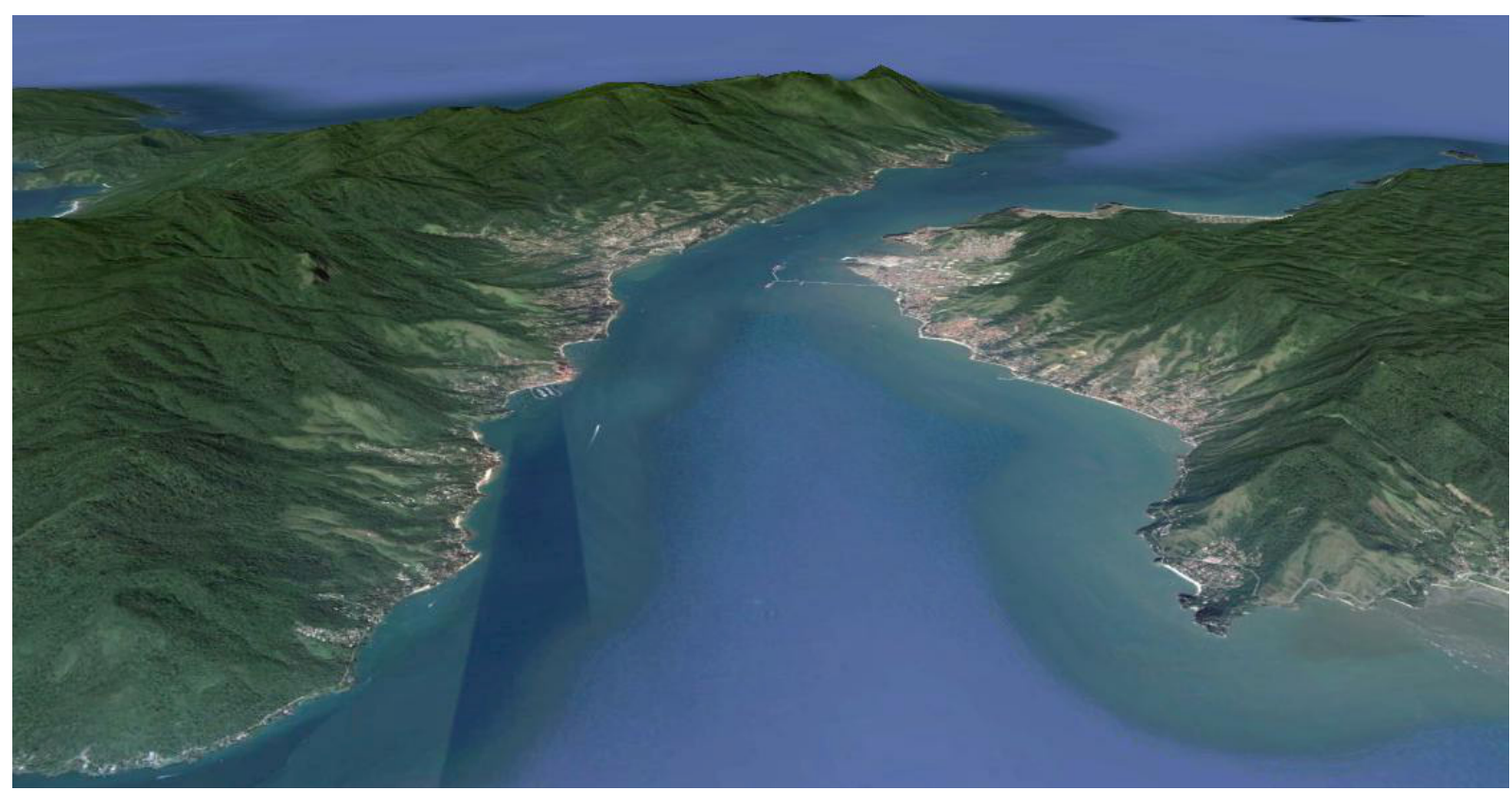

Fonte: Google Earth (2014).

Figura 15 - Vista aérea do Canal de São Sebastião

A travessia marítima de veículos entre os municípios de São Sebastião e Ilhabela acontece através das balsas desde a década de 1950 e operadas até os dias de hoje pelo Dersa (Desenvolvimento Rodoviário S/A). Entretanto, podemos afirmar que este canal natural de mobilidade ${ }^{16}$ é pouco utilizado, principalmente para o transporte público entre municípios.

\footnotetext{
${ }^{16}$ SEMOB (Secretaria Nacional de Transporte e da Mobilidade Urbana - Ministério das Cidades): Responsável pela política de mobilidade urbana sustentável. O Governo Federal, em conjunto com os Estados e Municípios, apoia o desenvolvimento e implementação de uma Política Nacional de Mobilidade Urbana Sustentável, que tem como principal objetivo promover acesso amplo e democrático ao espaço urbano, priorizando os modos de transporte coletivo e os não motorizados, de forma segura, socialmente inclusiva e sustentável.

A atuação da SEMOB estabelece:

- $\quad$ Promover a cidadania e a inclusão social por meio da universalização do acesso aos serviços públicos de transporte coletivo e do aumento da mobilidade urbana.

- $\quad$ Promover o aperfeiçoamento institucional, regulatório e da gestão no setor.

- Coordenar ações para a integração das políticas da mobilidade e destas com as demais políticas de desenvolvimento urbano e de proteção ao meio ambiente.

- Organizar cidades a partir dos corredores.
} 
Faltam projetos e investimentos de mobilidade náutica na região considerando as condições naturais ambientalmente favoráveis à navegação, diminuindo distâncias físicas e sociais entre as cidades de São Sebastião, Ilhabela, Caraguatatuba e Ubatuba, seus centros históricos e ainda outros destinos de interesse dentro dos municípios e até fora do estado, como a cidade de Paraty, Angra dos Reis e Ilha Grande, no estado do Rio de Janeiro.

Em 1998 a prefeitura de Ilhabela lançou o Concurso Nacional para Readequação da Paisagem Urbana em seu município, vencido pela equipe de arquitetos José Magalhães Jr. e José Francisco Xavier Magalhães. Entre as diversas propostas apresentas, duas relacionadas diretamente com o canal e a navegação. Uma delas foi o terminal turístico de transatlânticos nacionais e internacionais, com acesso direto ao centro histórico do município de Ilhabela, e a outra, a implantação da primeira hidrovia para o transporte de passageiros no Litoral Norte do estado de São Paulo, conforme Figura 16.

Em sua fase inicial de operação, foi proposta a conexão dos bairros entre a balsa e o centro histórico de Ilhabela e posteriormente a ampliação da rede de mobilidade náutica com conexôes municipais, interligando de maneira regular os centros históricos das cidades de Ilhabela, São Sebastião, Caraguatatuba e Ubatuba, através de um consórcio regional para compartilhar custos, adquirir escala e viabilizar recursos.

Infelizmente não houve empenho e vontade do poder público em avançar com estas propostas e a região continua atrasada na utilização deste potencial.

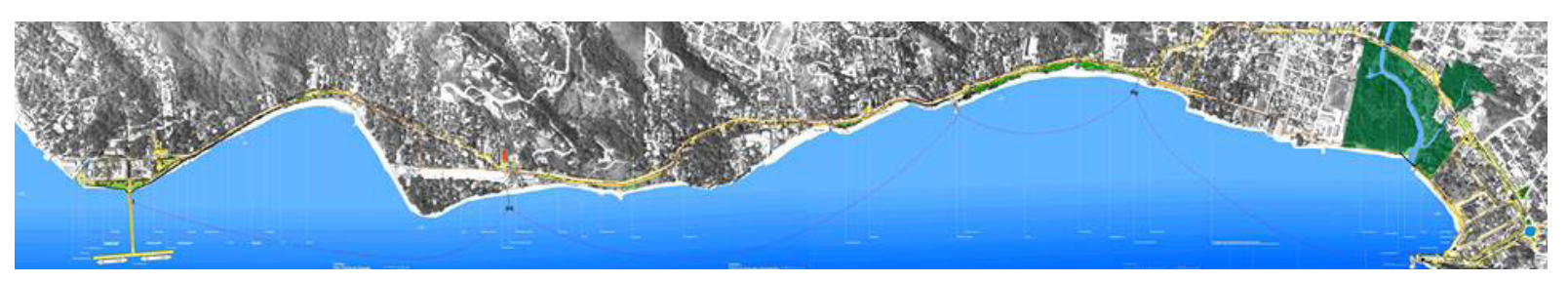

Fonte: Magalhães (1998).

Figura 16 - Proposta de Hidrovia e Terminal Turístico para Transatlânticos - $1^{\circ}$ lugar no Concurso Nacional para Readequação da Paisagem Urbana do Município de Ilhabela, SP, 1998 Arquitetos José Magalhães Jr. e José Francisco Xavier Magalhães.

A possibilidade de implantar as primeiras hidrovias no Litoral Norte do estado de São Paulo destinado ao transporte público, com embarcações adequadas para enfrentar a diversidade do mar, mantendo regularidade, conforto e segurança, como, por exemplo, os catamarãs de alta velocidade com condições de percorrer maiores distâncias, deveriam ser incluídos nas políticas públicas dos diversos municípios como prioridade, o que permitiria que o território fosse ativado em outras localidades costeiras com um sistema de transporte hidroviário de baixo impacto ambiental e ainda articulado aos demais sistemas de transportes existentes.

Sabemos que o Canal de São Sebastião, por suas características geográficas e suas potencialidades, gera grande interesse econômico e ao mesmo tempo evidentes conflitos. 
Ao mesmo tempo em que o lugar oferece profundidades naturais e águas abrigadas, faltam espaços em terra, principalmente nos municípios de São Sebastião e Ilhabela, que já esgotaram a utilização e ocupação de suas planícies entre a Serra do Mar e o mar.

Como aproveitar então as características sem comprometer a qualidade ambiental e urbana da região?

A grande questão é como acomodar as propostas dos novos equipamentos em estudo, como, por exemplo, a ampliação do porto comercial de São Sebastião, que não dispõe de áreas para o novo volume de mercadoria, principalmente as cargas transportadas por contêineres, sem contar com toda infraestrutura necessária para o seu transporte adequado, como rodovias e ferrovias, e, ainda, lugar para todos os equipamentos urbanos, como áreas habitacionais, de lazer, escolas, postos de saúdes, entre outros necessários para suprir o crescimento da população, atraídos principalmente pelas oportunidades de trabalho direto e indireto.

Além disto, a interface terrestre no canal de São Sebastião corre riscos até pelas próprias legislações ambientais, como o novo Código Florestal, lei no 12.651, de 25/05/2012, que estabelece normas gerais sobre a proteção da vegetação, áreas de preservação permanente e as áreas de reserva legal, determinando, por exemplo, a total preservação dos manguezais arbóreos em toda a sua extensão por considerar ecossistemas importantíssimos como berçário de grande parte da vida marinha, incluindo pescado considerado de grande valor econômico. Como exemplo desse tipo de área temos o manguezal do Araçá, na cidade de São Sebastião, local escolhido para a ampliação do porto comercial.

Mas se estes locais forem considerados de utilidade pública ${ }^{17}$ estarão isentos em respeitar qualquer legislação tanto do âmbito federal, estadual e municipal. Poderão ser suprimidos com respaldo legal deixando de respeitar tudo o que justificava sua proteção. No mínimo mereceria maiores discussōes, caso a caso.

Além de avaliar os custos ambientais e o ônus a ser atribuído a um território e a sua população pela perda definitiva de um determinado patrimônio, a utilidade pública necessita ser entendida no

\footnotetext{
${ }^{17}$ O Código Florestal, lei no 12.651 , de 25 de maio de 2012, considera as seguintes atividades de utilidade pública: - $\quad$ Atividades de segurança nacional e proteção sanitária.

- $\quad$ Atividades e obras de defesa civil.

- Obras de infraestrutura destinadas às concessões e aos serviços públicos de transporte, sistema viário, inclusive aquele necessário aos parcelamentos de solo urbano aprovados pelos Municípios, saneamento, gestão de resíduos, energia, telecomunicações, radiodifusão, instalações necessárias à realização de competiçôes esportivas estaduais, nacionais ou internacionais, bem como mineração, exceto, neste último caso, a extração de areia, argila, saibro e cascalho. Porto público, administrado pela Companhia Docas de São Sebastião (vinculada à Secretaria de Estado de Transportes de São Paulo) desde 2007 (convênio entre Governo Federal e Estadual) e um dos únicos que possui todas as licenças ambientais de operação.

Os principais produtos de importação são: barrilha, sulfato de sódio, malte, cevada, trigo, produtos siderúrgicos, máquinas e equipamentos, bobinas de fio de aço e cargas gerais. Para a exportação os principais produtos que passam pelo Porto de São Sebastião são: veículos, peças, máquinas e equipamentos, produtos siderúrgicos e cargas gerais.
} 
caso da ampliação do Porto de São Sebastião como interesse e uso estritamente privado, ou melhor, um local público, protegido ambientalmente e declarado de utilidade pública para ser utilizado de maneira privada.

\subsection{Cabotagem e carga de projeto com alternativa aos contêineres}

$\mathrm{O}$ porto comercial ${ }^{18}$ localizado no canal de São Sebastião, que possui características geográficas privilegiadas, oferecidas pelas grandes profundidades, conforme já abordado, está em processo de licenciamento ambiental para garantir a sua ampliação. A construção de mais um berço oferecerá às embarcações calados de até 16 metros de profundidade e isento de dragagens.

Atualmente (2014) o porto comercial, segundo a Companhia Docas de São Sebastião, possui 460 trabalhadores portuários responsáveis pelo embarque e desembarque de cargas em geral, offshore, ${ }^{19}$ contêineres, operações de cabotagem e carga de projeto.

O sistema de cabotagem, feita por navios nacionais entre os portos do mesmo país, podem contribuir no desenvolvimento da economia regional. É um meio de transporte mais barato em relação aos outros modais, seguro e ecologicamente sustentável. Ampliar o fluxo de mercadorias entre portos por este sistema deveria ser considerado como um potencial a ser explorado.

Em 2008 o porto comercial de São Sebastião concorreu com o porto comercial do Rio de Janeiro para montagem da plataforma de Mexilhão e ganhou pelas suas características e vantagens geográficas.

A Petrobras utilizou a operação de cabotagem no porto comercial de São Sebastião para suas operaçōes offshore na implantação e construção do gasoduto (plataforma de Mexilhão), principalmente dos berços 202 e 203, além da zona secundária (já compactada) como canteiro de obra para suas plataformas na camada pré-sal. Peças nacionais e internacionais foram montadas dentro deste setor, um grande canteiro de obras internacional, onde mecanismos podem ser acopladas e embarcadas novamente para seu destino final sem a burocracia de passar pelo sistema alfandegário.

O Porto de São Sebastião apresenta grande oportunidade para este tipo de operação, denominada cargas de projeto, o que poderíamos considerar como verdadeira opção aos contêineres.

\footnotetext{
${ }^{18}$ Porto público, administrado pela Companhia Docas de São Sebastião (vinculada à Secretaria de Estado de Transportes de São Paulo) desde 2007 (convênio entre Governo Federal e Estadual) e um dos únicos que possui todas as licenças ambientais de operação. Os principais produtos de importação são: barrilha, sulfato de sódio, malte, cevada, trigo, produtos siderúrgicos, máquinas e equipamentos, bobinas de fio de aço e cargas gerais. Para a exportação os principais produtos que passam pelo Porto de São Sebastião são: veículos, peças, máquinas e equipamentos, produtos siderúrgicos e cargas gerais.

${ }^{19}$ Atividades náuticas afastadas da costa, principalmente relacionadas com exploração petrolíferas em alto mar.
} 


\subsection{Transporte ferroviário}

$\mathrm{O}$ transporte ferroviário, um sistema considerado mais sustentável do ponto de vista ambiental e urbano, que pode oferecer segurança e entrega dentro dos prazos estabelecidos e preço mais competitivo na economia de escala, não foi sequer mencionado nos estudos de impacto ambiental como uma possível hipótese para o escoamento de contêineres e outros produtos.

$\mathrm{Na}$ década de 1990 o Porto de São Sebastião contratou um estudo para ampliação do porto comercial. Como podemos verificar na Figura 17, a proposta preserva o manguezal do Araçá, considera o aterro como eventual possibilidade e apresenta uma possível conexão ferroviária com o Porto de Santos, que não foi adiante e muito menos alimentou outros debates.

Atualmente, empresas logísticas como a MRS (Malha Regional Sudeste) operam, monitoram e interligam o Porto de Santos com o interior do estado de São Paulo, Rio de Janeiro e Minas Gerais através da malha ferroviária federal (figura18). Atualmente não existem estudos em andamento para uma possível conexão da malha ferroviária com o Porto de São Sebastião.

O estudo denominado Programa de Trens Regionais, elaborado pela Companhia Paulista de Trens Metropolitanos - CPTM, é o único que considera uma possível ligação ferroviária entre a cidade de São José dos Campos e Caraguatatuba, no Litoral Norte de São Paulo, mas apenas em 2040 e para o transporte de passageiros.

Podemos então constatar que dentro de um contexto regional ainda não existe uma proposta de rede integrada entre portos e os demais modais, com estudos de soluções conjuntas para viabilizar mais e melhor mobilidade de cargas e pessoas que inclua a cidade e o Porto de São Sebastião.

\subsection{Litoral paulista e o Porto de Santos.}

$\mathrm{O}$ s portos comerciais de Santos e São Sebastião, localizados no litoral paulista, são considerados os portos marítimos mais importantes do Brasil e necessitam a elaboração de estudos conjuntos para encontrar caminhos mais sustentáveis e de caráter regional. É necessário que seja disciplinada as disputas portuárias, para não fomentar um desequilibro, onde as maiores vítimas serão o meio natural, as cidades e a própria população.

Pelo Porto de Santos, considerado o maior da América Latina, passam 55\% do Produto Interno Bruto, sendo 38\% só do estado de São Paulo. Abastece 45\% do mercado de consumo de todo o país. ${ }^{20}$ Está praticamente a $100 \mathrm{~km}$ de distância da grande São Paulo e Campinas, que juntas somam 20 milhões de habitantes e 25\% do PIB nacional, e menos de 100 km do Porto de São Sebastião.

\footnotetext{
${ }^{20}$ Em 2012, o Porto de Santos movimentou 50 milhōes de toneladas. Principais produtos: contêineres, açúcar, café, laranja, algodão, adubo, carvão, trigo, sucos, veículos, graneis líquidos, entre outros.
} 


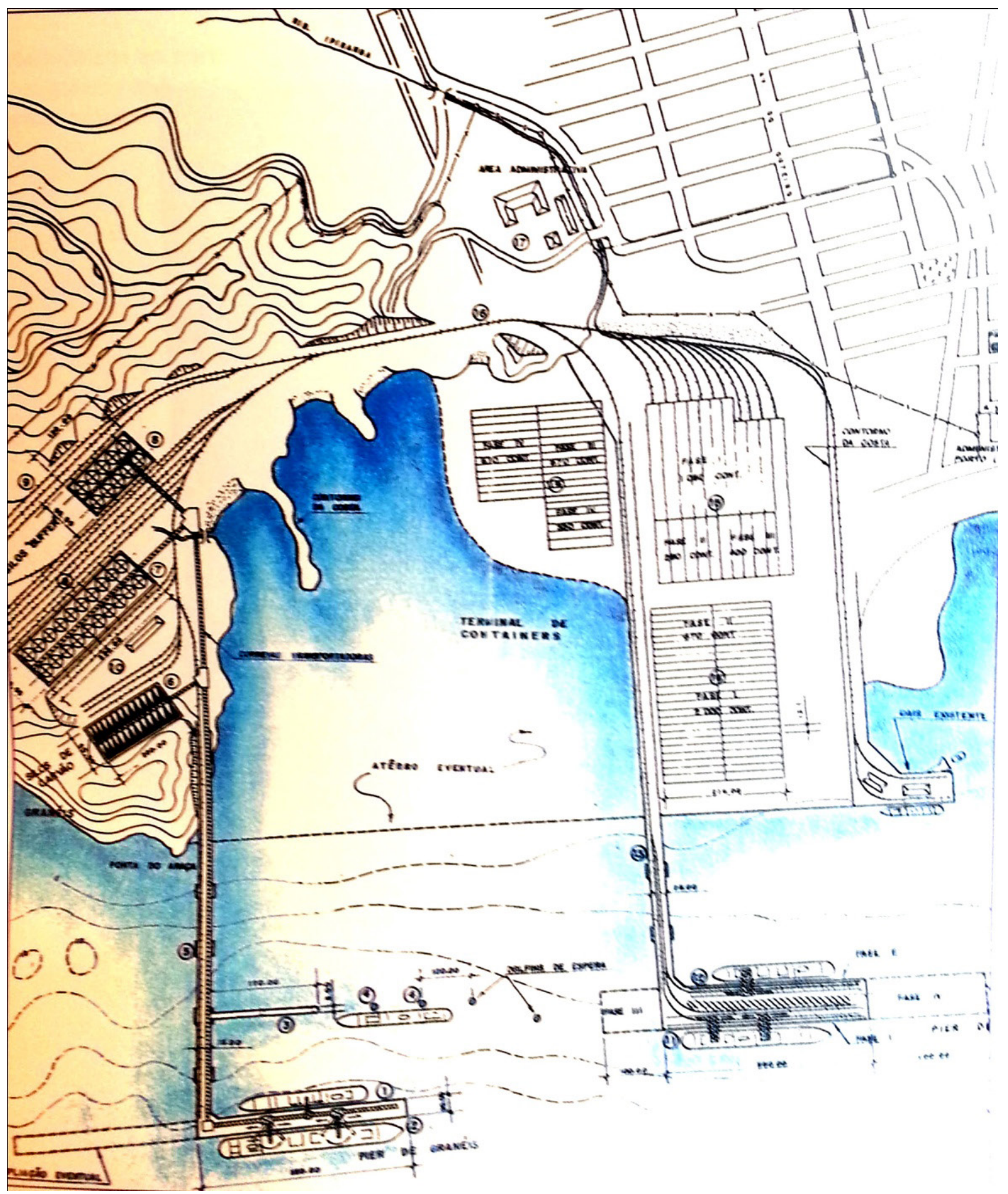

Fonte: Brasconsult (1998).

Figura 17 - Estudo para Ampliação do Porto Comercial, São Sebastião em 1998

Elaborado pela empresa BRASCONSULT. Destaque para o Transporte Ferroviário - conexão com o Porto de Santos. 


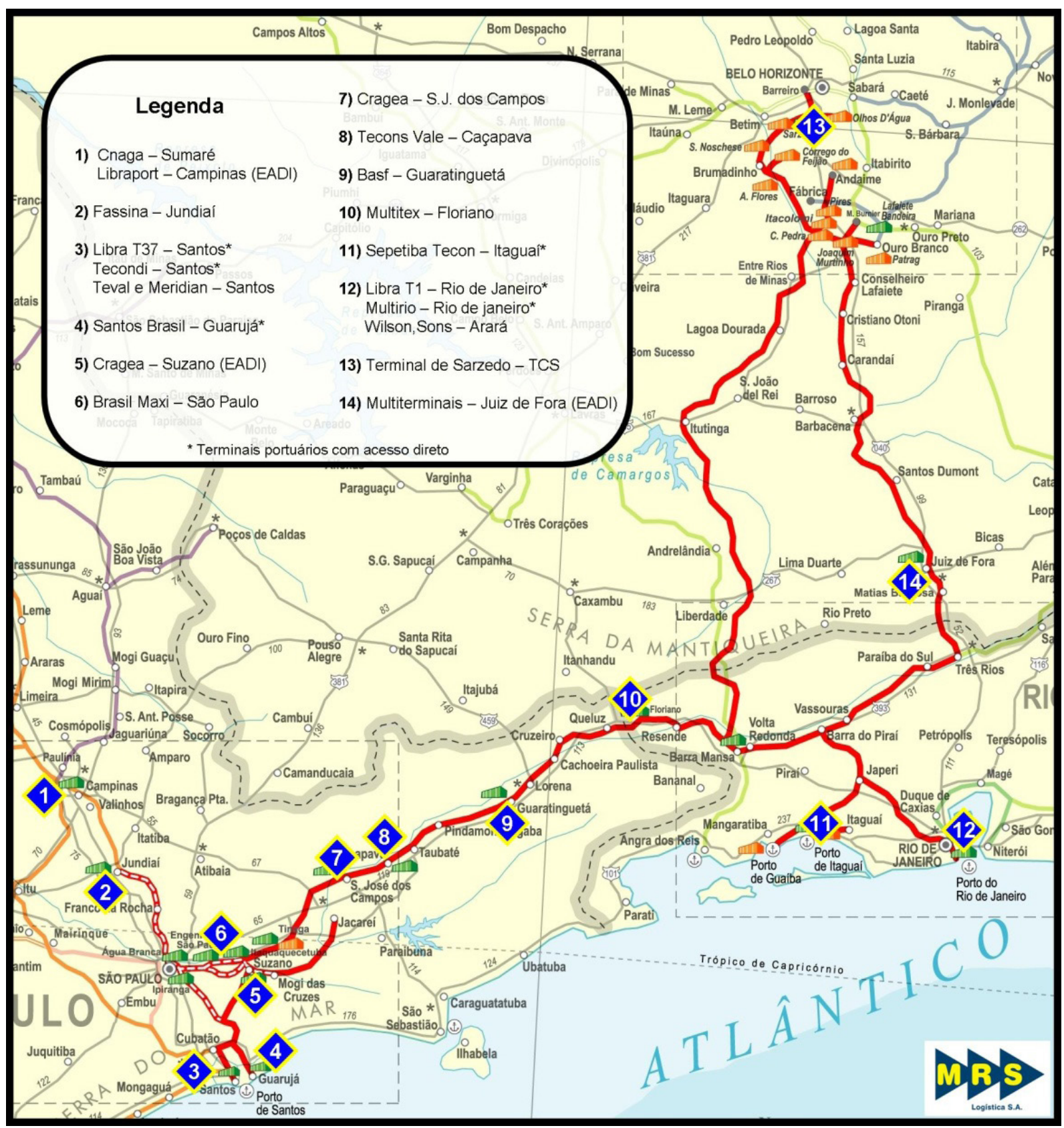

Fonte: MRS (2014).

Figura 18 - Principais rotas ferroviárias - São Paulo, Minas Gerais e Rio de Janeiro

O Porto de Santos vem sendo modernizado através de parcerias entre órgãos públicos e privados. O principal objetivo é conseguir maior agilidade nas operações com novos equipamentos e tecnologia, para ser mais competitivo e ainda conseguir reduzir suas tarifas portuárias. ${ }^{21}$ É admi-

${ }^{21}$ Principais medidas do Plano de Modernização para o Porto de Santos:

- Transferência das operaçōes portuárias para empresas privadas.

- Implantação do Porto 24 Horas, com mais agilidade na movimentação das cargas e diminuição do tempo de permanência dos navios no cais.

- Construção de um túnel de 2.700 metros sob o estuário de Santos, entre as margens esquerda e direita do porto. 
nistrado atualmente pela Companhia Docas do Estado de São Paulo (CODESP), que arrendou e privatizou a maioria dos terminais dentro do programa de modernização das instalações portuárias, mas, apesar disto, o governo deveria atuar com mais firmeza, exigindo um planejamento e organização portuária em uma escala regional e até nacional.

A utilização do território costeiro, principalmente os fronteiros às águas no Litoral Norte do estado de São Paulo, estão sendo conduzidas fundamentalmente pelos interesses privados e com apoio público, o que vem condicionando um modelo de desenvolvimento não integrado.

A presença cada vez maior das grandes infraestruturas, complexos turísticos e diversas residências de verão, criando verdadeira barreira de acesso à costa marítima, vem provocando a privatização da orla e consolidando a descontinuidade da paisagem litorânea, bloqueando cada vez mais a abertura urbana em direção ao mar.

As potencialidades geográficas estão sendo privatizadas sem levar em conta a importância da preservação do patrimônio histórico, cultural e ambiental da região.

Desenhar e implantar um projeto integrado de caráter público para a costa litorânea, que insira o potencial náutico (lazer, esporte, transporte público e não apenas o de transporte de mercadorias e petróleo) e evite impactar de forma irresponsável e definitiva neste território costeiro, de especial interesse geográfico, principalmente por suas características naturais exclusivas, deveria ser um compromisso a ser perseguido e assegurado por lei.

Será fundamental planejar e desenhar hoje, para evitar em um curto espaço de tempo grandes gastos financeiros na contenção da poluição, deterioração urbana e ambiental.

- Aprofundamento do canal para até $17 \mathrm{~m}$, permitindo o acesso de grandes navios.

- Derrocamento da pedra de Teffé $\left(57 \mathrm{mil} \mathrm{m}^{3}\right)$ e da Itapema $\left(24 \mathrm{mil} \mathrm{m}^{3}\right)$.

- Melhorar o saneamento básico com sistema de esgoto sanitário, coleta e disposição final de resíduos nas áreas próximas à zona portuária, garantindo a qualidade das águas no canal de Santos.

- Nova Avenida Perimetral, com o objetivo de adequar o sistema viário à segunda pista da rodovia dos Imigrantes e retirar o trânsito urbano de dentro do porto. 


\section{CAPÍTULO III}

0 ATERRO

São Sebastião e a implantação do aterro em frente ao seu centro histórico. 


\section{0 ATERRO E O CENTRO HISTÓRICO DE SÃO SEBASTIÃO}

\subsection{História da implantação do aterro em São Sebastião}

$\mathrm{E}$ studos técnicos realizados para a cidade de São Sebastião, como o Plano Estadual de Gerenciamento Costeiro, Macrozoneamento do Litoral Norte, Plano Municipal de Turismo e o Plano Diretor, consideram como importante potencial do município o desenvolvimento das atividades náuticas. Indicaram também o aterro na frente do centro histórico da cidade como local adequado para a implantação de uma marina.

A história do aterro inicia-se na década de 1980, a partir das negociaçōes entre Governo do Estado e Petrobras, que tinham como objetivo viabilizar novas áreas na cidade de São Sebastião para ampliar suas atividades (Figura19).

A Petrobras necessitava expandir sua área para construir dois tanques de armazenamento de petróleo (12,8 milhões de litros). Era preciso realizar o desmonte de um morro (200.000 $\mathrm{m}^{3}$ de rocha) localizado dentro de suas instalaçôes (“Gleba D” do Terminal Marítimo Almirante Barroso) para conseguir novos espaços.

O Governo do Estado de São Paulo, através do Departamento Hidroviário, também desejava ampliar o porto comercial, uma oportunidade para conciliar seus interesses com os da Petrobras, ou seja, as rochas do morro desmontado seriam utilizados como enrocamento na execução dos dois aterros hidráulicos em frente à orla marítima da cidade.

O primeiro aterro, entre o atual porto comercial até a ponta do Araçá, para o retroporto, com $557.700 \mathrm{~m}^{2}$ (não construído), ${ }^{22}$ e o segundo aterro, ao norte do ferry boat em frente ao centro histórico (Figura 20), foi subdividido em duas áreas, onde uma delas seria utilizada pelo próprio Departamento Hidroviário, com $19.000 \mathrm{~m}^{2}$, e a outra, com $69.120 \mathrm{~m}^{2}$, cedida à Prefeitura Municipal para infraestruturas de lazer e recreação e que foi construído ${ }^{23}$ e justificado pelo Estudo de Impacto ambiental como veremos a seguir.

\footnotetext{
${ }^{22}$ A previsão para a construção do aterro hidráulico era utilizar material a ser dragado nas proximidades dos berços de acostagem do Tebar $\left(1.400 .000 \mathrm{~m}^{3}\right)$.

${ }^{23}$ O EIA-RIMA utilizou como principal argumento para justificar o aterro na frente do centro histórico que a cidade ganharia novas áreas de lazer. Podemos entender também que o local foi escolhido como "bota fora" do morro desmontado e que locais mais distantes tornariam esta operação muito mais cara.
} 


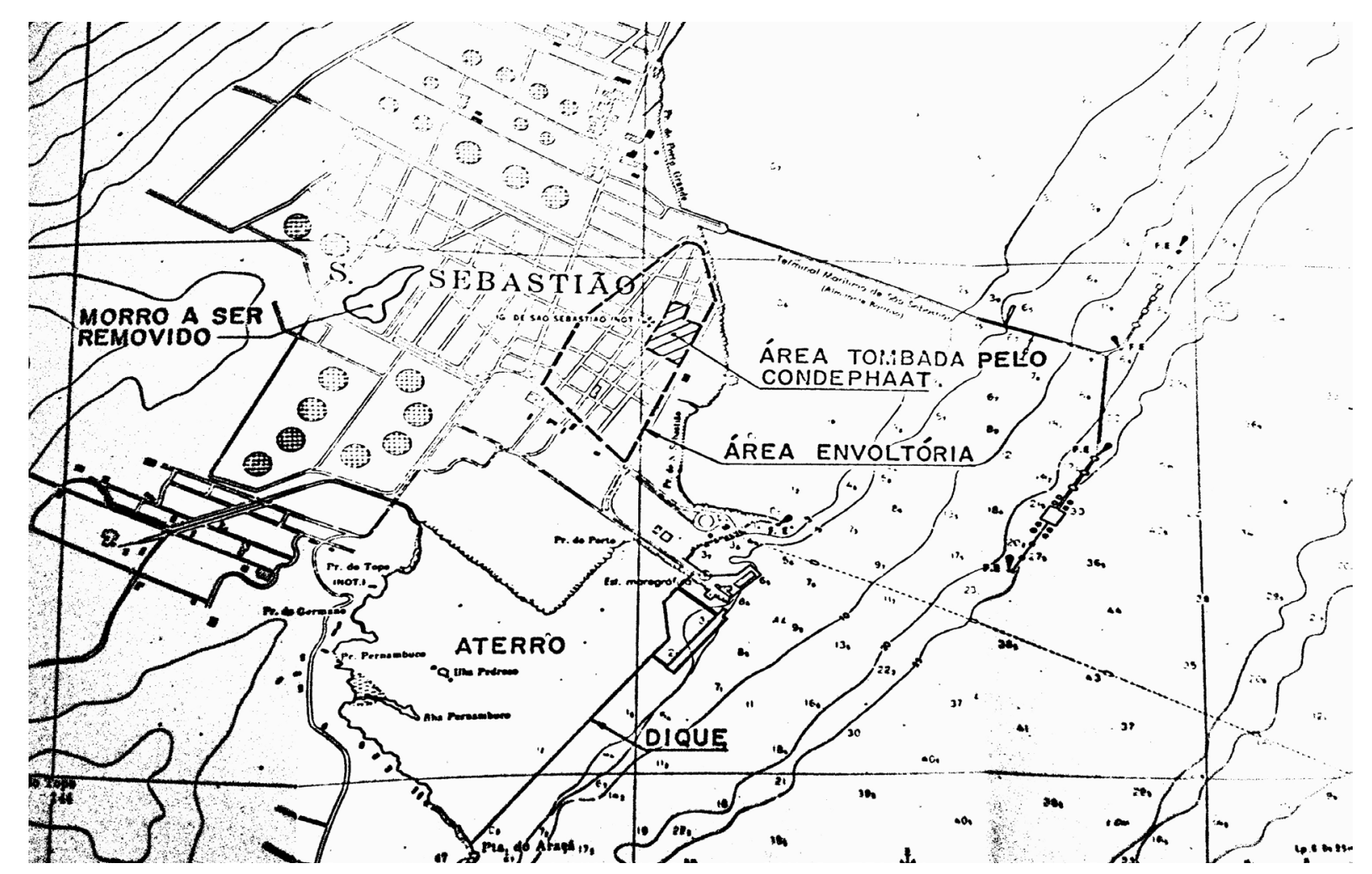

Fonte: Relatório de Impacto do Meio Ambiente - RIMA. HIDROSERVICE (1987).

Figura 19 - Localização do aterro e obras de desmonte do morro de rocha descomposta na Gleba D do TEBAR, em São Sebastião - SP

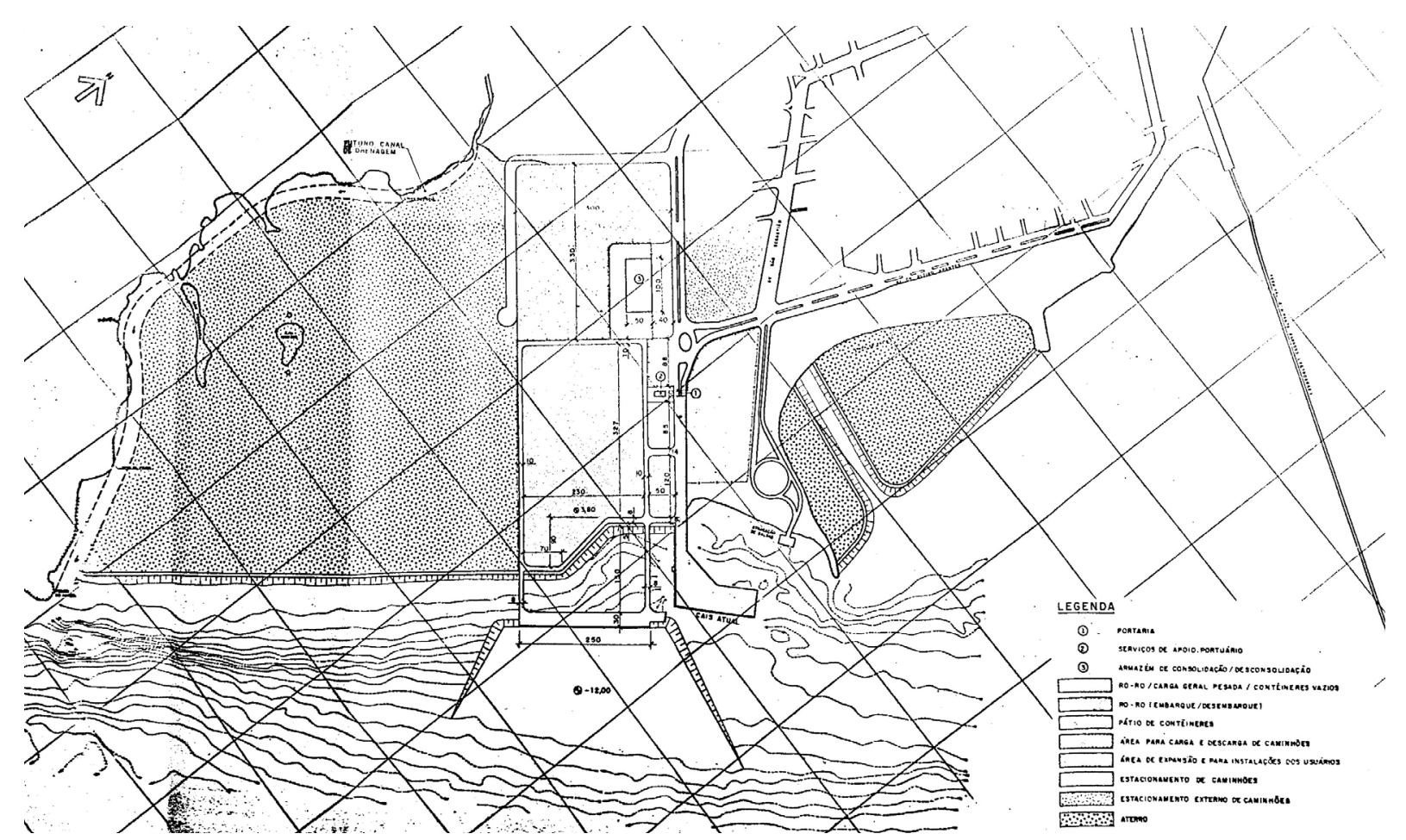

Fonte: Relatório de Impacto do Meio Ambiente - RIMA. HIDROSERVICE (1987).

Figura 20 - Layout geral dos aterros em São Sebastião-SP 


\subsection{EIA-RIMA do aterro em frente ao centro histórico de São Sebastião}

egundo o EIA-RIMA do aterro no centro histórico da cidade de São Sebastião, elaborado pela $\checkmark$ HIDROSERVICE em março de 1987 (após o início das obras), o desmonte do morro para as novas áreas de tancagem e ampliação do porto, com os novos aterros hidráulicos, não causariam nenhum tipo de impactos negativos no meio biológico, meio socioeconômico, meio físico e no patrimônio histórico da cidade e região.

O relatório considerava ainda que as obras seriam responsáveis pelos benefícios socioeconômicos locais e regionais, tanto para Petrobras, com o aumento do armazenamento de petróleo, quanto para porto comercial, tornado-se mais competitivo, mas sobretudo para a cidade, que ganharia novas áreas de lazer e recreio, que, segundo o relatório, não possuía espaços para futuras ampliações de sua malha urbana, muito em função da Serra do Mar, ${ }^{24}$ portanto uma grande oportunidade.

Mas na realidade o espaço gerado a partir do aterro (Figura 21), apesar de ampliar as áreas defronte ao centro da cidade, impactou negativamente com a alteração de uma das características históricas mais importantes de São Sebastião, a sua proximidade e conexão com o mar, onde o centro foi separado de sua frente marítima. ${ }^{25}$

A linha d'água está hoje a mais de 200 metros de distância da sua posição original. Além disso, o aterro, com aproximadamente $65.000 \mathrm{~m}^{2}$, é uma área ambientalmente modificada e com baixa qualidade de solo.

O espaço gerado a partir do aterro impactou negativamente na cidade e no meio ambiente, comprovando que o EIA-RIMA cometeu um grande equívoco em seus estudos.

\subsection{Revitalização urbana do centro histórico de São Sebastião}

$\mathrm{E}$ m 1988 a Prefeitura Municipal de São Sebastião, ciente dos impactos negativos do aterro na cidade, promoveu um Concurso Público Nacional de Ideias, organizado pelo Instituto de Arquitetos do Brasil, Departamento São Paulo, para a implantação de uma marina e revitalização urbana do centro histórico da cidade.

\footnotetext{
${ }^{24} \mathrm{O}$ relatório coloca apenas esta condicionante, a Serra do Mar, como fator da falta de espaço para a cidade. Não podemos nos esquecer que tanto o porto quanto a própria Petrobras ocupam grandes áreas centrais e são os maiores responsáveis pela falta de espaço urbano neste setor da cidade.

${ }^{25}$ A alternativa adotada na década de 1980 causou grande impacto ambiental e na paisagem cênica do centro histórico da cidade de São Sebastião, o que não foi considerado pelo EIA-RIMA como problema.
} 


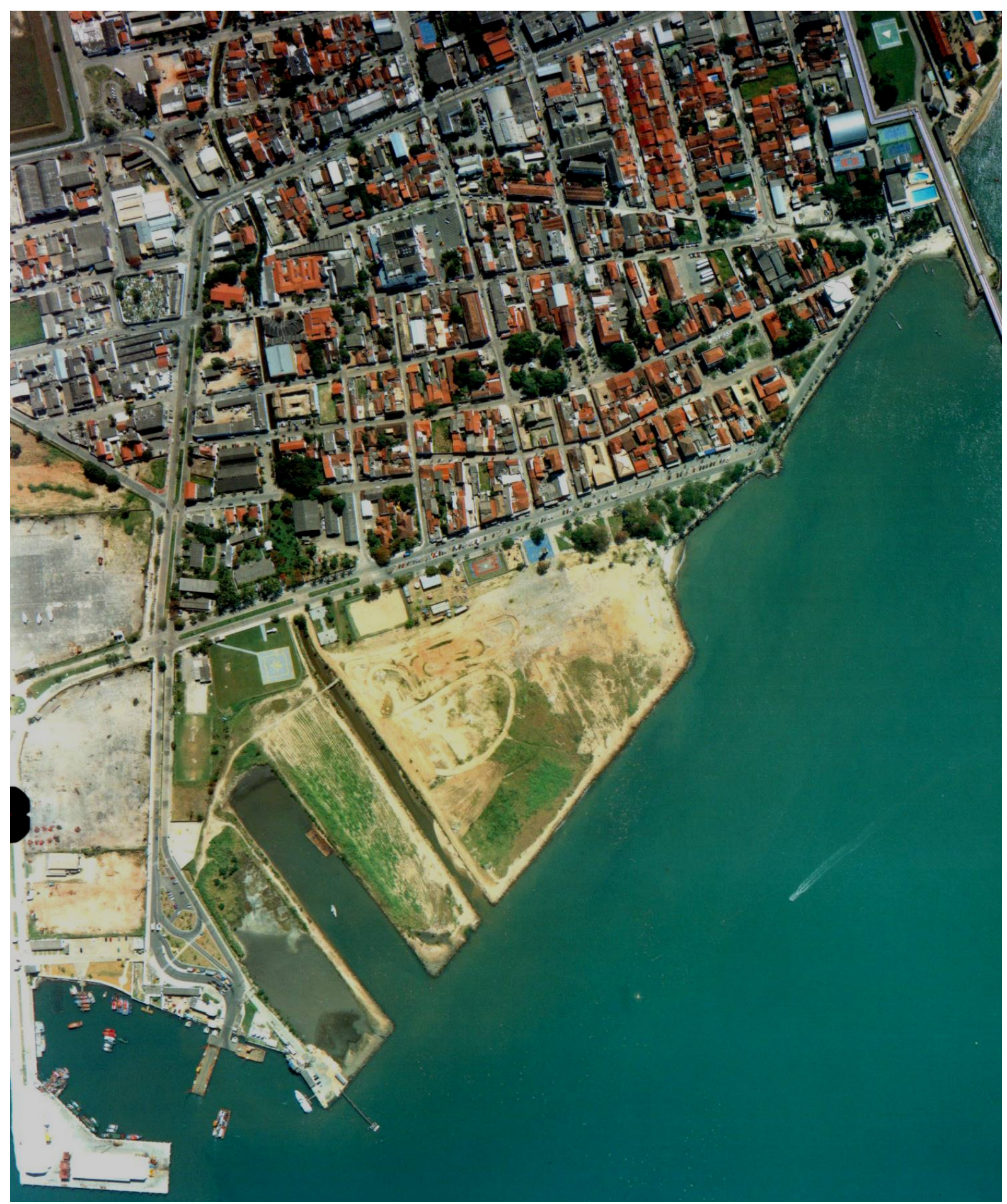

Fonte: FUNCATE / BASE S A. Foto ${ }^{\circ} 277$ (1998).

Figura 21 - Foto aérea - São Sebastião

O desafio colocado pelo concurso era propor uma solução para o aterro através de um novo espaço náutico, que pudesse funcionar de forma integrada com a cidade e sua população, ou seja, reverter o grande erro cometido no passado por um Estudo de Impacto Ambiental que aprovou e licenciou a construção do aterro, e rearticular novamente o espaço terrestre com o espaço marinho, 
através de uma nova atividade econômica: as estruturas de apoio às embarcaçóes de recreio e pesqueiras. Uma solução para incentivar a manutenção e qualificação do patrimônio histórico e ainda promover o desenvolvimento econômico e social de sua população, inserindo a São Sebastião no contexto global, fundamentalmente por suas especificidades territoriais.

A proposta elaborada pela equipe de arquitetos, José Magalhães Jr., José Francisco Xavier Magalhães e Cláudio Thomas Reuss para o concurso em 1998, com consultoria dos arquitetos Adilson Costa Macedo, José Ignácio Sequeiro de Almeida e Márcia Lucia Guilherme e o economista Luiz Renato Ignarra, obteve o primeiro lugar.

A solução buscou conciliar e equilibrar um programa específico para a marina, respeitando as questóes ambientais e que ao mesmo tempo atendesse tanto as embarcaçôes e seus usuários quanto à população local.

O objetivo era integrar a cidade de São Sebastião a um novo espaço náutico e não apenas a uma marina. Um local com características de porto de recreio (Figura 22), composta por instalações e serviços necessários às embarcações e a seus usuários, mas também associados a outros empreendimentos complementares, que configuravam um importante e central espaço público, ampliando os benefícios sociais e econômicos, principalmente para a comunidade local.

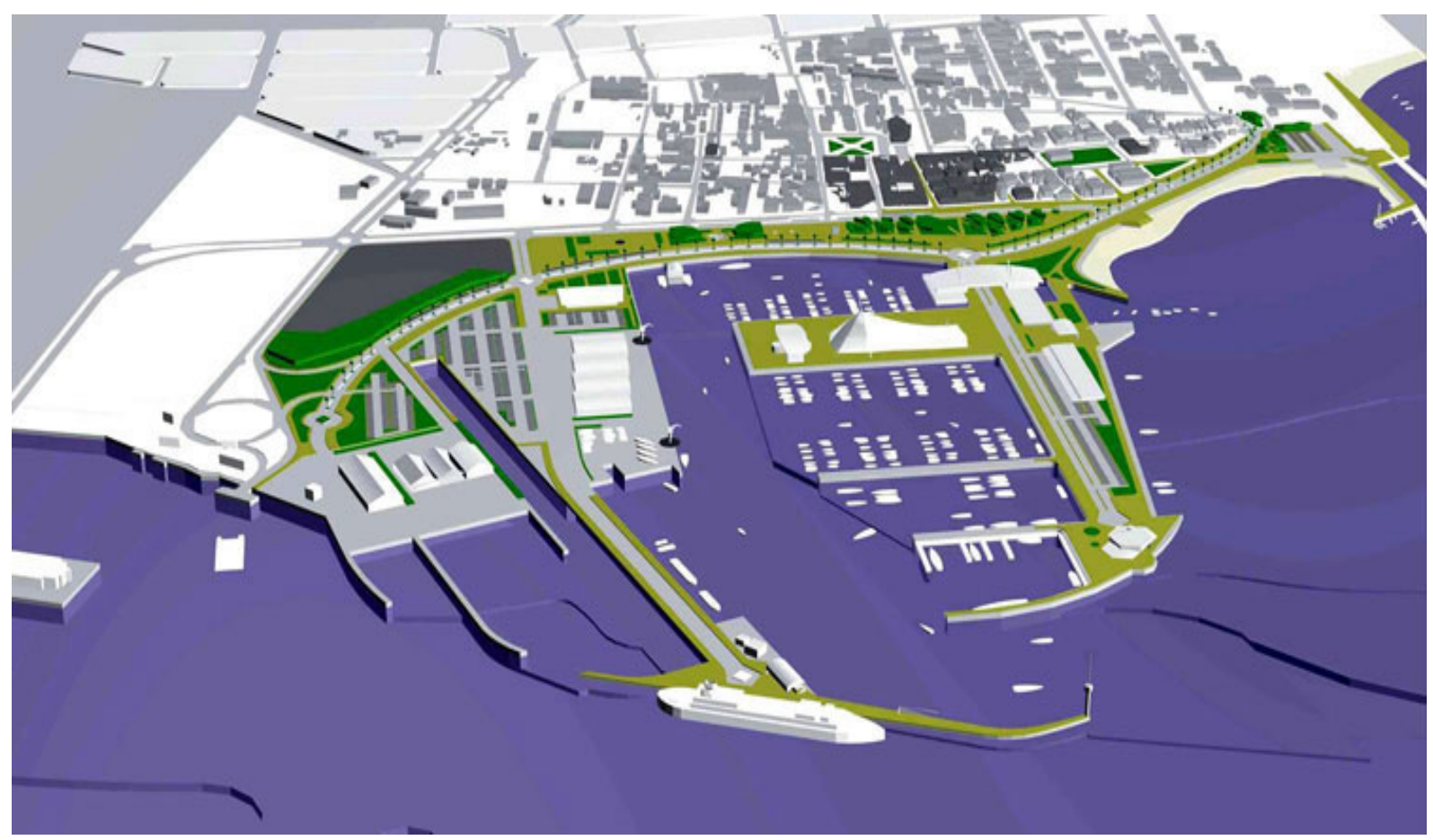

Fonte: José Francisco Xavier Magalhães (1998).

Figura 22 - Proposta para o Porto de Recreio da cidade de São Sebastião $1^{\circ}$ lugar no Concurso Nacional Marina Pública São Sebastião, SP - 1998.

Arquitetos José Magalhães Jr., José Francisco Xavier Magalhães e Claudio Thomas Reuss. 
Para o desenvolvimento dos trabalhos, a equipe levou em consideração o grande alcance econômico de um empreendimento deste tipo. A proposta buscou conciliar junto à marina atividades importantes, mas que não concorressem com os serviços já oferecidos pela cidade ou que pudessem se desenvolver em função das novas oportunidades.

A proposta apresentada tinha como conceito fundamental, preservar a importante fachada marítima, recuperando e resgatando a proximidade da linha d'água ao centro histórico da cidade (Figura 23), tombado pelo Patrimônio Histórico Nacional e Estadual. ${ }^{26}$

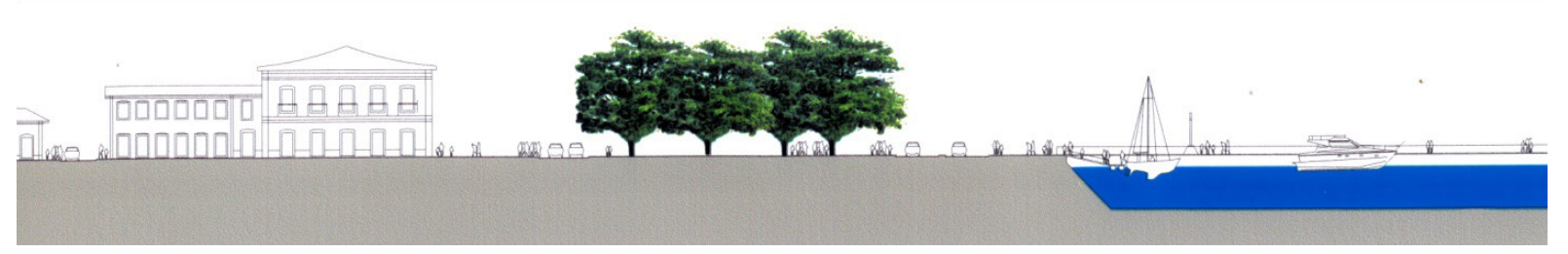

Fonte: José Francisco Xavier Magalhães (1998).

Figura 23 - Proposta para o Porto de Recreio da cidade de São Sebastião

Premissa projetual - reaproximar a linha d'água ao Centro Histórico de São Sebastião.

1 o lugar no Concurso Nacional Marina Pública São Sebastião, SP - 1998.

Arquitetos José Magalhães Jr., José Francisco Xavier Magalhães e Claudio Thomas Reuss.

As estruturas de apoio à navegação de recreio, se inseridos dentro dos contextos públicos e de recreação, principalmente próximo aos centros urbanos, onde já estão presentes condições adequadas, como infraestruturas urbanas e outras facilidades, tem a potencialidade de ampliar com qualidade real seus benefícios positivos para a maioria da população. É fundamental adquirir o conceito de portos de recreio ou de lazer para não correr o risco de ocupar as frentes marítimas com estruturas de apoio à navegação de caráter privado, que privilegiem uma pequena minoria ou, ao contrário, um grande parque temático, anexando construções de difícil remoção posterior e cargas programática tão intensa que apaguem as características próprias destas localidades.

Uma das grandes preocupaçôes na formulação do programa para a frente marítima da cidade de São Sebastião era a de conciliar os usos estabelecidos para o porto de recreio de tal forma que a cidade, mas principalmente o setor histórico, pudessem beneficiar-se econômica e socialmente. Para isto, uma operação urbana na área central seria necessária, para garantir uma interface mais equilibrada a partir do novo espaço náutico, indutor da revitalização do centro histórico. Foi proposto

${ }^{26}$ Outras condicionantes de projeto, que definiram a estrutura urbana, estavam baseadas nos seguintes conceitos: - Implantar a marina de forma equilibrada e harmônica com o centro histórico em três etapas complementares.

- Atender embarcações de diversos calados, escunas e outros barcos de aluguel.

- Maior parte das áreas projetadas tem o caráter e utilização pública.

- Equilíbrio programático: frente marítima complementada por serviços oferecidos e instalados no centro histórico.

- Fluxos urbanos integrados ao empreendimento (veículos, barcos e pedestres).

- Cuidados ambientais em relação à não interrupção dos fluxos das correntes marítimas dentro das bacias para diminuir o flushing time.

- Promover parcerias do setor público e privado, para os investimentos na frente marítima. 
um perímetro de intervenção urbana (Figura 24), englobando o centro histórico, áreas envoltórias, acrescidos de marinha, áreas complementares do centro, áreas verdes e livres, com as seguintes características:

- Nova política de uso e ocupação do solo.

- Taxas de concessão e taxas de serviços a incidir nas atividades do porto de recreio.

- Concessão de uso nas atividades da marina, gerenciado pela iniciativa privada.

- Incentivar atividades comerciais e de serviços no perímetro da operação urbana, em especial no centro histórico, voltado à vocação a ser implantada.

- Estabelecer a forma de participação da iniciativa privada, do poder público e as regras básicas para a manutenção do complexo.

- Compatibilizar a vocação das áreas dentro da Lei Orgânica do município de São Sebastião, do Plano Diretor, da Lei de Uso do Solo e do Código de Obras.

- Controle ambiental com participação e integração da comunidade no desenvolvimento do complexo.

A operação urbana proposta determinou cinco zonas de uso para o centro urbano, da seguinte forma: Z1 (áreas do centro histórico tombado), Z2 (áreas periféricas do centro histórico), Z3 (áreas complementares), Z4 (áreas administrativas e serviços) e Z5 (Áreas do novo complexo náutico).

Para cada uma destas zonas deveriam ser regulamentados critérios de uso, índices de ocupação, aproveitamentos, permissões e restrições específicas, levando em consideração os usos já estabelecidos.

Finalmente, estas estruturas náuticas vinculadas às questôes ambientais podem representar novos espaços náuticos flexíveis e coletivos, capazes de desencadear novas dinâmicas urbanas (Figura 25) nos territórios fronteiros à água, e a partir dos mesmos motivos históricos que levaram a escolha desses locais na costa brasileira, garantir a preservação permanente destas características e entender que a orla é um bem público. 


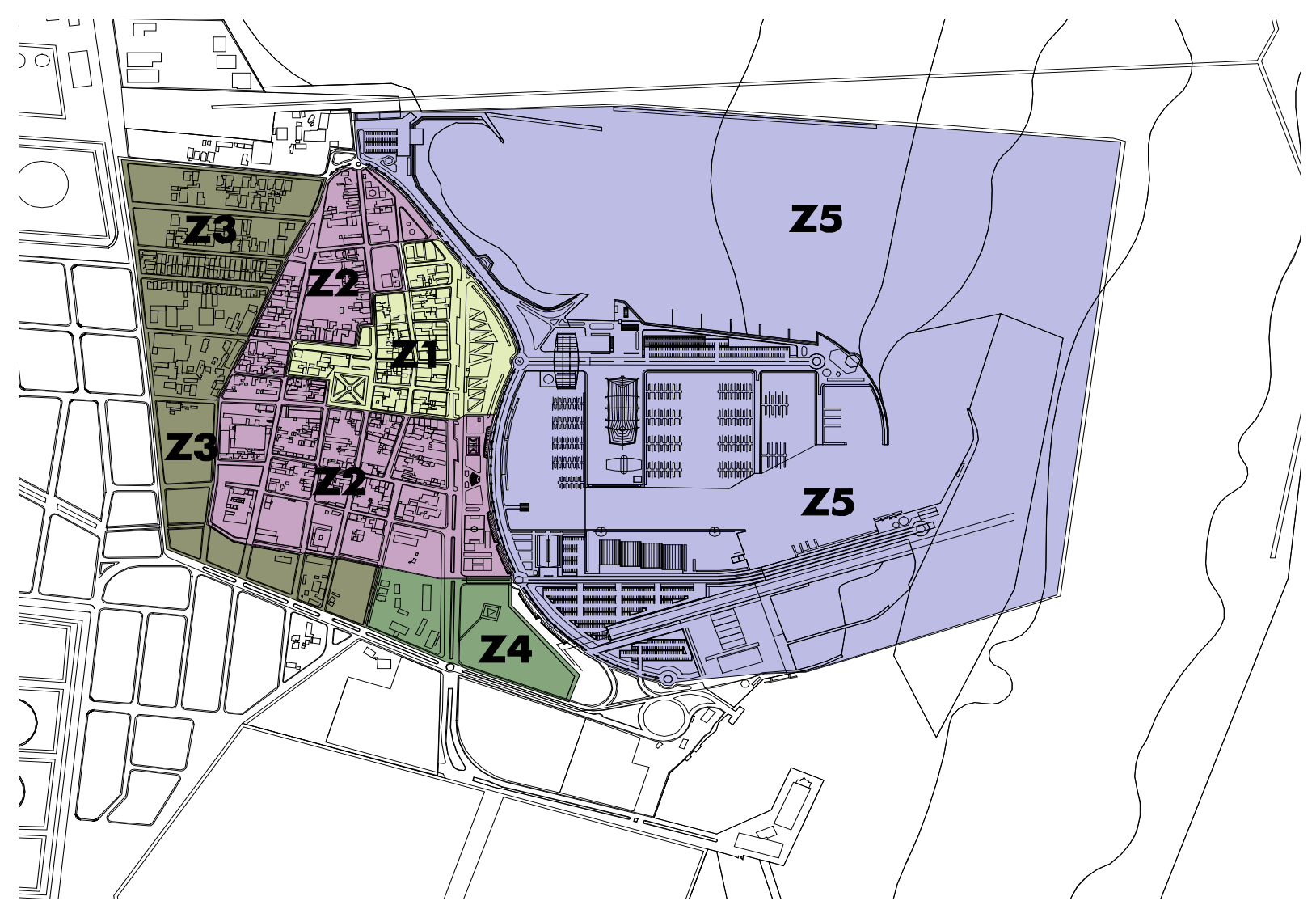

Fonte: José Francisco Xavier Magalhães - Concurso Marina Pública São Sebastião, 1998.

Figura 24 - Zoneamento proposto para o centro da cidade de São Sebastião RESIDÊNCIAS UNIFAMILIARES - R RESIDÊNCIAS MULTIFAMILIARES - RM COMÉRCIO LOCAL - C

COMÉRCIO DIVERSIFICADO - CD

COMÉRCIO ATACADISTA - CA COMÉRCIO TURÍSTICO - CT

SERVIÇOS ÂMBITO LOCAL - S SERVIÇOS DIVERSIFICADOS - SD

SERVIÇOS ESPECIAIS - SE

SERVIÇOS TURISMO - ST

INSTITUIÇÔES ÂMBITO LOCAL - I INSTITUIÇŌES DIVERSIFICADAS - ID

INSTITUIÇŌES ESPECIAIS - IE

USOS ESPECIAIS - U

$Z 1 R / R M / C / C^{*} / S / S^{*} / I^{*}$

Z2 R / RM / C / CT / S / ST/ / CONTROLE PARCIAL

$\mathrm{Z3} \mathrm{R} / \mathrm{RM} / \mathrm{C} / \mathrm{CD} / \mathrm{S} / \mathrm{SD} / \mathrm{I}$

$\mathrm{Z4} \mathrm{R} / \mathrm{RM} / \mathrm{C} / \mathrm{S} / \mathrm{I} / \mathrm{ID} / \mathrm{IE}$

$Z 5 \mathrm{C} / \mathrm{CD} / \mathrm{CE} / \mathrm{CT} / \mathrm{S} / \mathrm{SD} / \mathrm{SE} / \mathrm{ST}$ USOS ESPECIAIS

ÁREA TOMBADA

PERIMETRO DA OPERAÇÃO URBANA

\section{* COM CONTROLE do PADRÃo DE ARQUITETURA} CIRCULAÇÁO DE VÉ́CULOS LIMITADA

\subsection{0 potencial perdido no centro histórico de São Sebastião}

dentificar o potencial local e sua capacidade de suporte, valorizar e preservar as características
especifica da região, além de integrar, de forma equilibrada com a malha urbana existente, com seu patrimônio, sua memória e uma legislação adequada, podem evitar o planejamento de caráter meramente especulativo, movido apenas por interesses econômicos preocupados somente com o sucesso dos empreendimentos construídos próximos à linha d’água. 


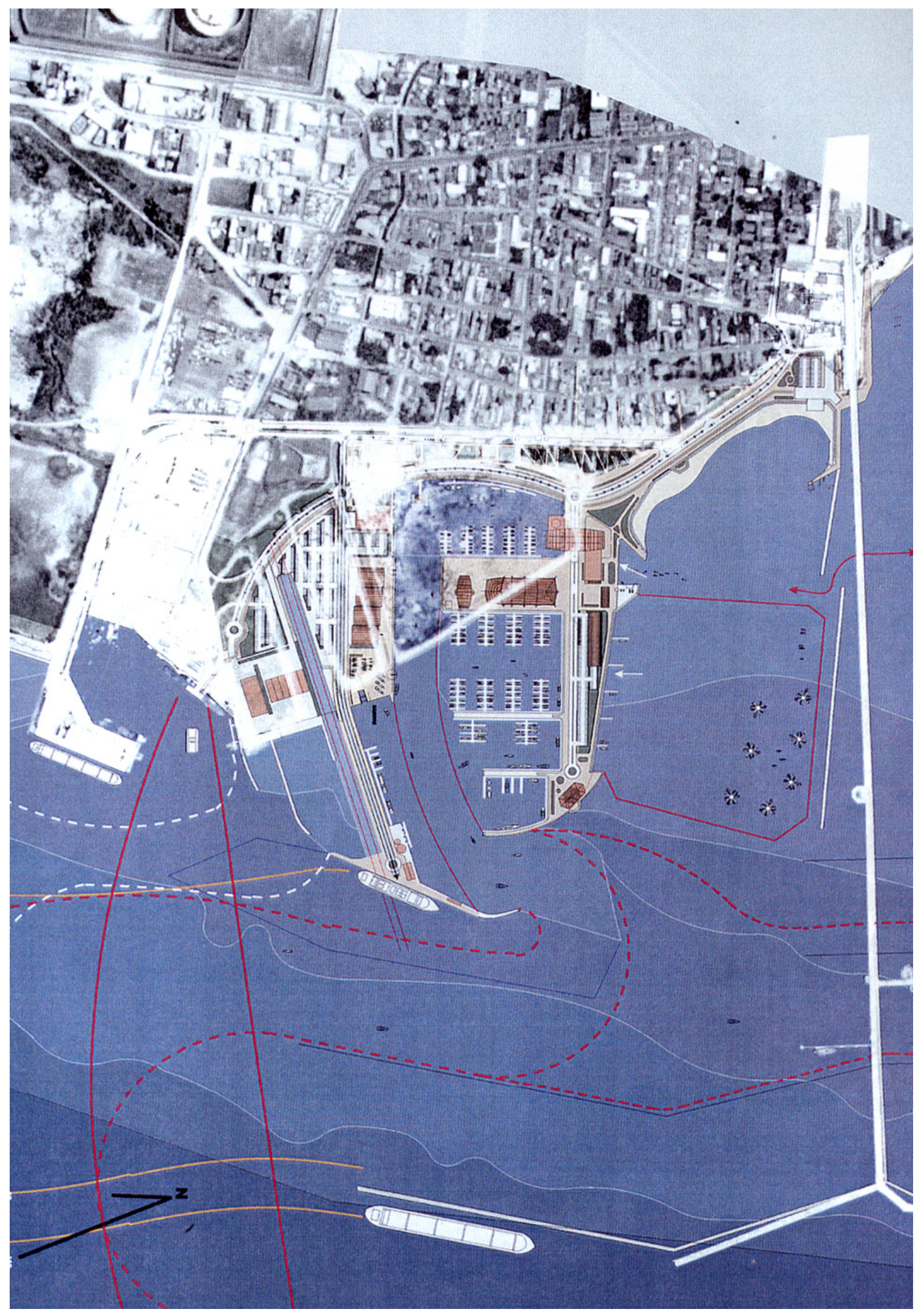

Fonte: José Francisco Xavier Magalhães (1998).

Figura 25 - Fotomontagem da proposta para o Porto de Recreio da cidade de São Sebastião Porto de recreio inserido dentro do contexto da cidade com valorização de suas características históricas. $1^{\circ}$ lugar no Concurso Nacional Marina Pública São Sebastião, SP - 1998.

Arquitetos José Magalhães Jr., José Francisco Xavier Magalhães e Claudio Thomas Reuss. 
A costa brasileira, com seus inúmeros recursos e produtos naturais, sua condição climática, sem grandes variações de temperatura ao longo das diversas estaçôes, as extensas águas navegáveis, determina uma situação adequada para ampliação e utilização destes recursos. Será necessário estabelecer regras claras de utilização das fronteiras do território com as águas navegáveis, principalmente para garantir o domínio público. Apesar do grande interesse econômico, estes espaços são considerados recursos naturais finitos e áreas ambientalmente frágeis, asseguradas por legislação específica.

Atualmente, a falta de estruturas de apoio à navegação de recreio que ofereçam vagas na água fez crescer o número de garagens náuticas com vagas secas, que nada mais são do que depósitos de barcos em terra onde, na maioria das vezes, estão localizados longe da linha d'água e desencadeiam limitados benefícios econômicos e sociais para suas cidades.

O setor náutico brasileiro ainda possui poucos investimentos feitos nesta área, no entanto, existe um enorme potencial de desenvolvimento para a extensa faixa litorânea, com $7.408 \mathrm{~km}$ de costa linear navegável por doze milhas de largura, chamada de mar territorial, ${ }^{27}$ sujeita à soberania do Brasil, além das 200 milhas a partir do mar territorial, chamada Zona Econômica Exclusiva, ${ }^{28}$ que, apesar do país não exercer soberania, possui direito exclusivo em explorar os recursos econômicos existentes na água, tanto no solo quanto no subsolo marinho. Estes números estabelecidos na Convenção das Nações Unidas para o Direito do Mar demonstram que o Brasil possui dentro d'água aproximadamente $4.400 .000 \mathrm{~km}^{2}$ de território a ser explorado.

Apesar das grandes extensões de águas navegáveis, da história naval brasileira, das condições climáticas favoráveis ao setor de turismo náutico e de lazer, faltam embarcaçōes e instalações náuticas no litoral e no interior do território.

O acesso a bens naturais e públicos, como o mar, represas e os diversos rios navegáveis, ainda é pouco utilizado e fica restrito a uma minoria. Para reverter este processo e desenvolver o setor, é fundamental criar uma nova cultura náutica. Construir novas estruturas de apoio às embarcações associadas a um sistema de mobilidade pública e mais sustentável, através dos territórios marinhos e fluviais, pode ser um novo caminho.

Estas estruturas são consideradas grandes indutoras de desenvolvimento econômico, e com os estudos adequados, projetos corretos e bem operados, terão amplo retorno social e financeiro. Uma equipe multidisciplinar com conhecimento nas questôes relacionadas ao empreendimento, obras náuticas, arquitetura, urbanismo, meio ambiente, legislação, oceanografia, viabilidade econômica, entre outras, será necessária para avaliação de todos os aspectos envolvidos.

Apesar da oportunidade exclusiva ao setor náutico, já destacados pelo Plano Estadual de Gerenciamento Costeiro, o Macrozoneamento do Litoral Norte do estado de São Paulo, o Plano Muni-

\footnotetext{
${ }^{27}$ Conforme Parte II, Artigo $3^{\circ}$ da Convenção das Nações Unidades sobre o Direito do Mar, 1982.

${ }^{28}$ Conforme Parte V, Artigo $57^{\circ}$ da Convenção das Nações Unidades sobre o Direito do Mar, 1982.
} 
cipal de Turismo e pelo próprio Plano Diretor, a construção de um porto de recreio para incentivar o setor náutico e resgatar as características históricas da cidade de São Sebastião, e sua proximidade com o mar, poderia reverter o gravíssimo erro do aterro justificado por seu EIA-RIMA.

Apesar disto, não houve empenho da própria Prefeitura em levar adiante a revitalização deste espaço e o seu potencial náutico.

$\mathrm{O}$ aterro ficou por mais de duas décadas praticamente abandonado. Foi utilizado de forma parcial em alguns eventos musicais, atividade com duvidoso retorno econômico para cidade, mas com grande impacto negativo na infraestrutura do centro histórico.

Em 2010 o aterro foi urbanizado (Figuras 26 e 27), com usos e arquiteturas no mínimo questionáveis (Figuras 28, 29, 30, 31, 32 e 33), como espaço zen para meditação, bosque para piquenique, arvorismo mirim, playground lúdico musical, espaço para melhor idade com equipamentos de ginástica, concha acústica, pista de patinação, observatório ambiental e lanchonetes. O potencial náutico, seja para estruturas e embarcações de recreio, pesca ou transporte hidroviário, não foi considerado.

A urbanização implantada compromete ainda mais a possibilidade de regatar a importância do centro histórico e sua relação com o Canal de São Sebastião.

Foi construído também um píer (40 metros de comprimento e 3,5 metros de largura), muito menor do que o próprio projeto abaixo propunha, inviabilizando a atracação de embarcações, o que demostra claramente a falta de empenho e entendimento do poder público em relação à importância desta área para um desenvolvimento mais consistente do segmento náutico como suporte a embarcações de recreio e transporte hidroviário de passageiros. Uma verdadeira, importante e consistente oportunidade econômica qualificada para o centro histórico da cidade de São Sebastião foi novamente descartada.

A retomada das características centrais das frentes marítimas, recuperando a importante fronteira entre cidade e porto, depende da elaboração de programas com usos compatíveis, relacionados às especificidades geográficas e de uma forma urbana equilibrada para obter conexões mais permeáveis e duradouras. A urbanização implantada pela prefeitura no aterro de São Sebastião, com atividades programáticas diversas, genéricas e artificiais, em conjunto com a ampliação do Porto de São Sebastião, desencadeará problemas ainda mais sérios para seu centro histórico, onde a ideia de equilíbrio urbano fica cada vez mais distante.

Segundo Lamas, em sua obra Morfologia urbana e desenho da cidade, para desenhar e intervir é necessário conhecer e compreender a cidade antiga e a cidade moderna, suas morfologias e processos de formaçôes, pesquisando o tema, para aprofundar conhecimentos, amadurecer ideias e acumular experiências. É fundamental também estudar o processo de evolução com seus aspectos históricos, culturais, econômicos, sociais, físico-espaciais e morfológicos, para identificar diferenças. Estas análises são importantes, pois, segundo ele, nos levam a conhecer a forma urbana, afinal, todos estes elementos que refletem a produção do espaço. 


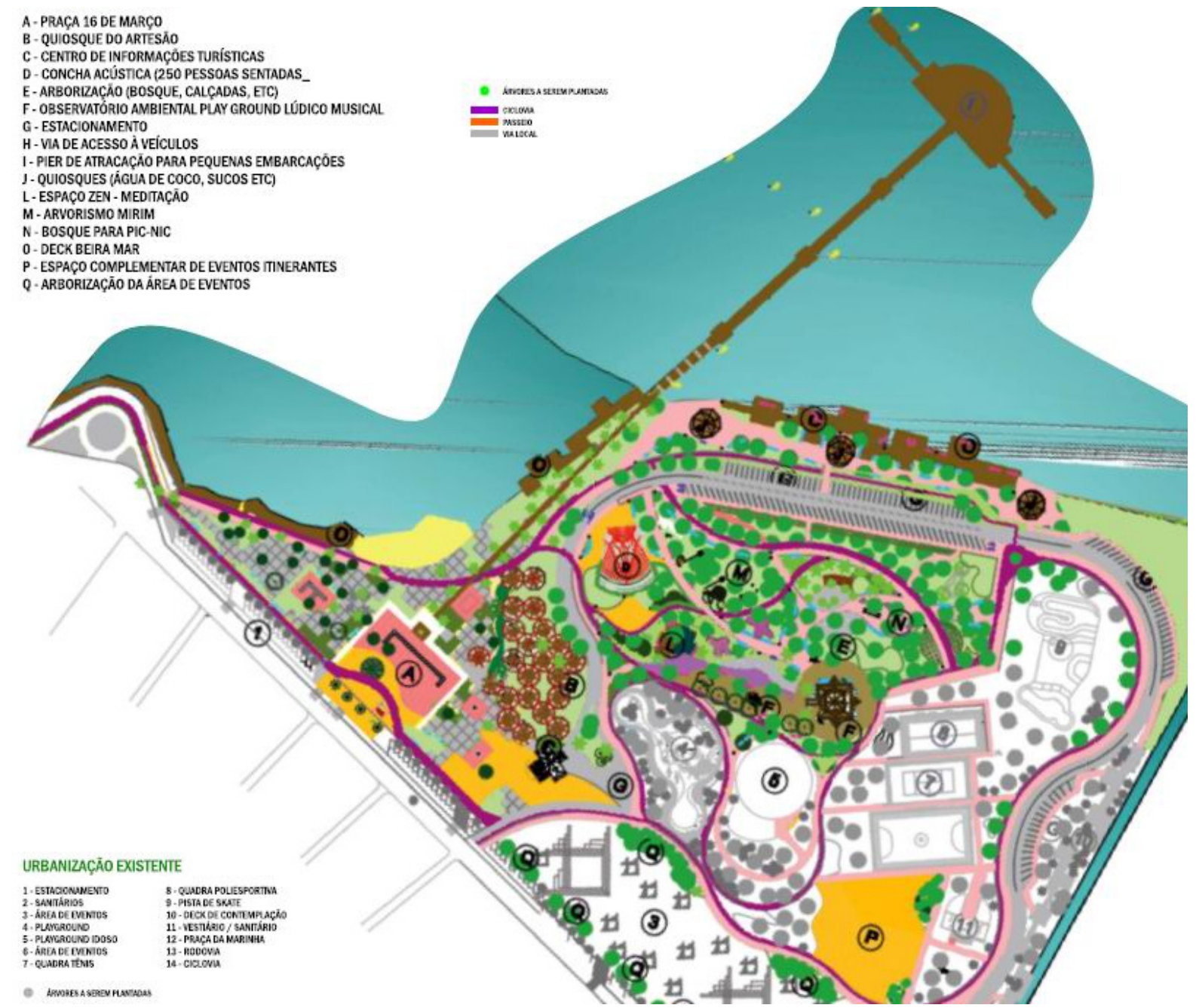

Fonte: Prefeitura Municipal de São Sebastiāo (2010).

Figura 26 - Projeto de urbanização do aterro de São Sebastião, elaborado pela prefeitura de São Sebastião

A forma urbana, segundo o autor, é o aspecto físico das relações econômicas, sociais, políticas e culturais num determinado espaço, e também da produção voluntária, baseada em objetivos de planejamento e representadas pelo desenho urbano, através da interpretação dos contextos econômicos, políticos e sociais, que resultam em teorias, posições culturais e estéticas dos arquitetos urbanistas, responsáveis em contribuir com a forma urbana mais humanizada, através de um método de trabalho que tenha uma visão global dos problemas.

No caso de São Sebastião e região, não temos estudos em andamento que considerem todos os projetos em uma análise conjunta. Faltam estudos e desenhos cumulativo dos empreendimentos de grande porte e principalmente dos que necessitam de estudos de impacto ambiental, prejudicado uma compreensão mais precisa dos impactos na área como um todo. 


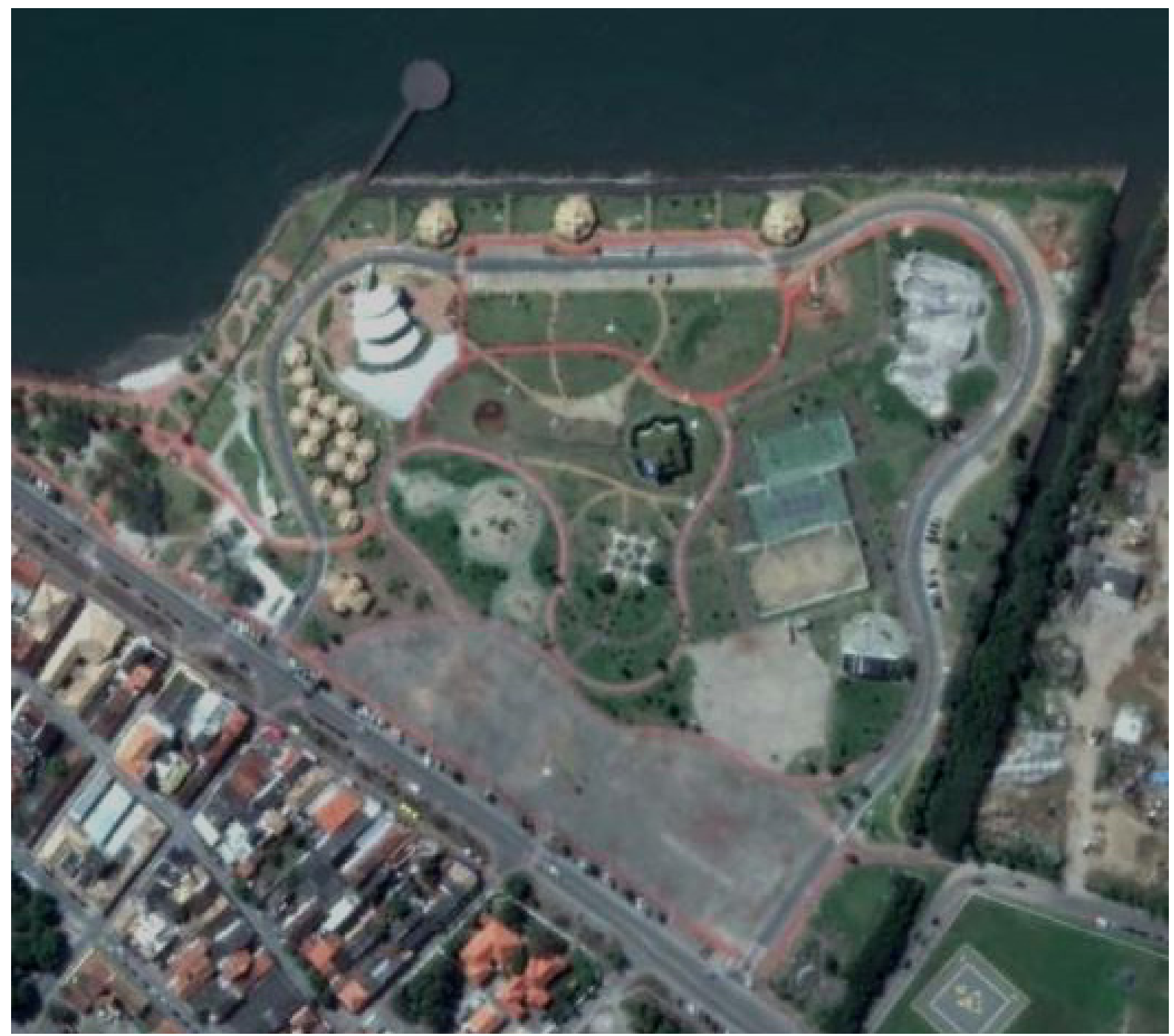

Fonte: Google Earth (2014).

Figura 27 - Implantação do projeto de urbanização do aterro de São Sebastião, 2014

\subsection{São Sebastião 2030}

$\mathrm{O}$ próximo e maior equívoco para cidade de São Sebastião começou a se tonar realidade no ano de 2014, a partir da liberação da LP (Licença Prévia) emitida pelo IBAMA para dar prosseguimento aos projetos de ampliação do porto comercial, com prioridade para os contêineres.

O órgão licenciador aceitou as justificativas apontadas pelo EIA-RIMA, de que os benefícios positivos serão muito maiores do que os benefícios negativos, e sem maiores questionamentos e novas exigências de estudos, ou dados técnicos mais aprofundados, principalmente em relação aos aspectos sinergéticos e cumulativos com os demais empreendimentos também em processo de licenciamento na região, emitiu a LP. 


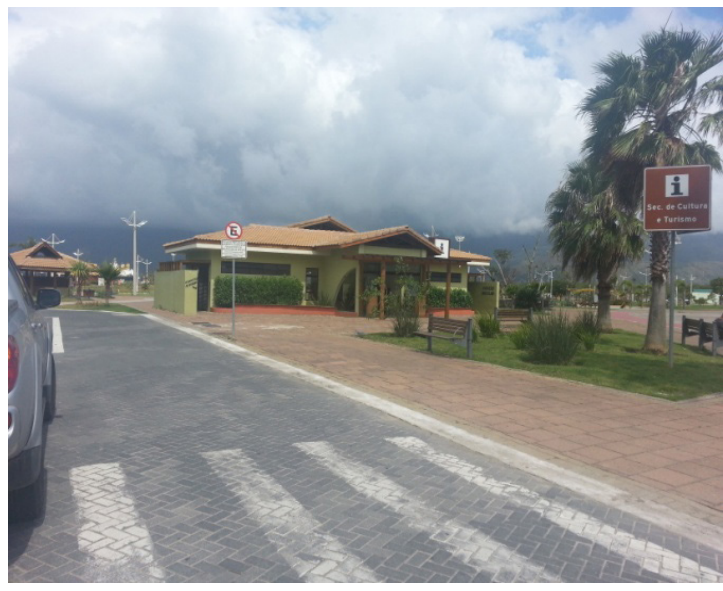

Figura 28 - Sanitários e Centro de Informação Turística

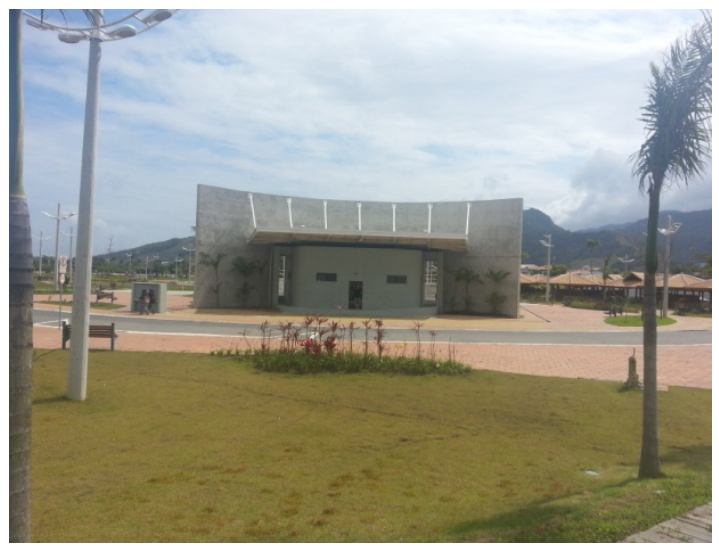

Figura 30 - Concha acústica

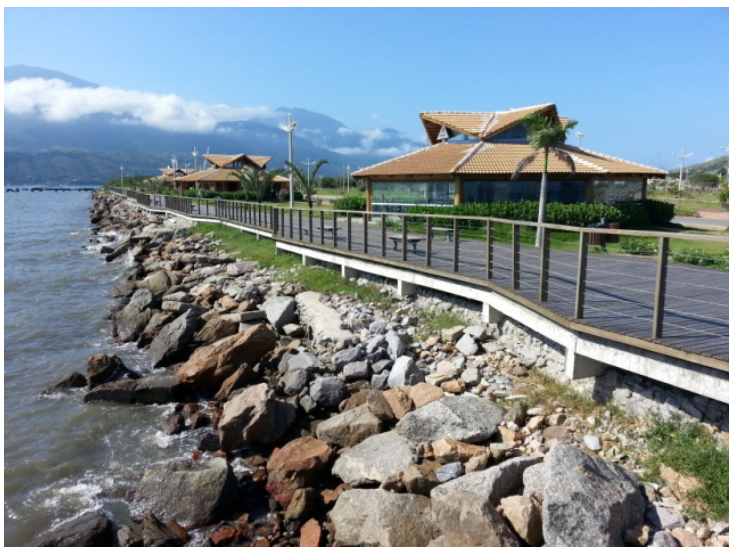

Figura 32 - Lanchonetes

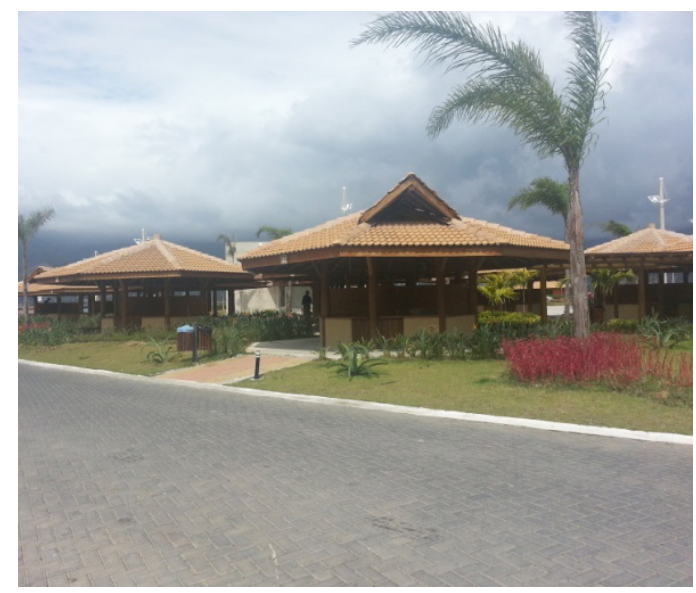

Figura 29 - Quiosques de artesanato

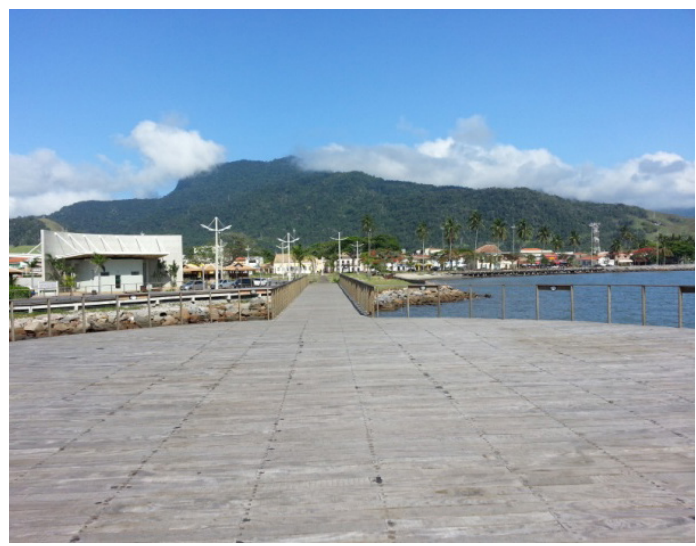

Figura 31 - Píer apenas para

contemplação

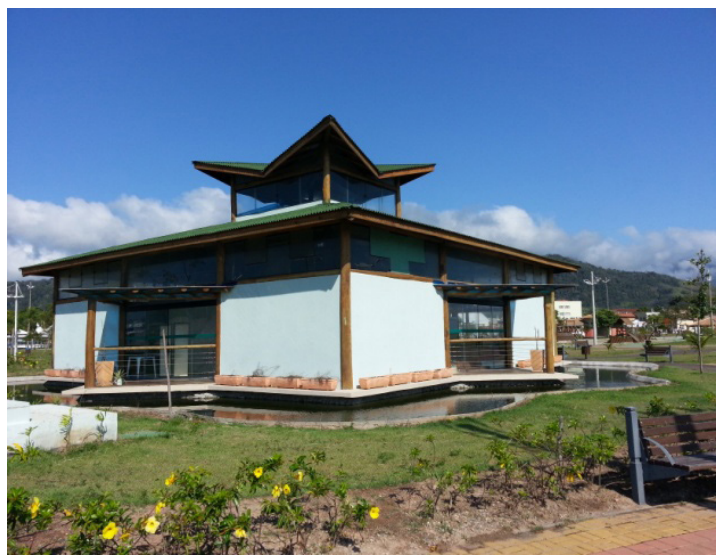

Figura 33 - Observatório ambiental

Fonte: José Francisco Xavier Magalhães, 2014. 
O empreendedor apresenta, através do EIA-RIMA, o cenário para 2030, ilustrados nas Figuras 34 e 35, o que poderíamos considerar como catastrófico para a cidade, principalmente para o centro histórico de São Sebastião, já ilhado entre as instalações da Petrobras, o aterro construído na década de 1980, o porto comercial e agora sua futura ampliação.

Apenas pela imagem já podemos notar que o projeto do empreendimento é absurdamente desproporcional ao lugar escolhido, além de comprometer definitivamente a ligação de São Sebastião com sua frente marítima.

O risco do impacto negativo adquire escala regional, ainda mais se consideramos os processos em andamento de aprovação e licenciamento da ampliação do píer da Petrobras, exploração da camada pré-sal, a duplicação do trecho Planalto da rodovia dos Tamoios, a construção do Contorno Norte (interligação com Caraguatatuba) e Contorno sul (interligação com São Sebastião) e a duplicação da SP-055.

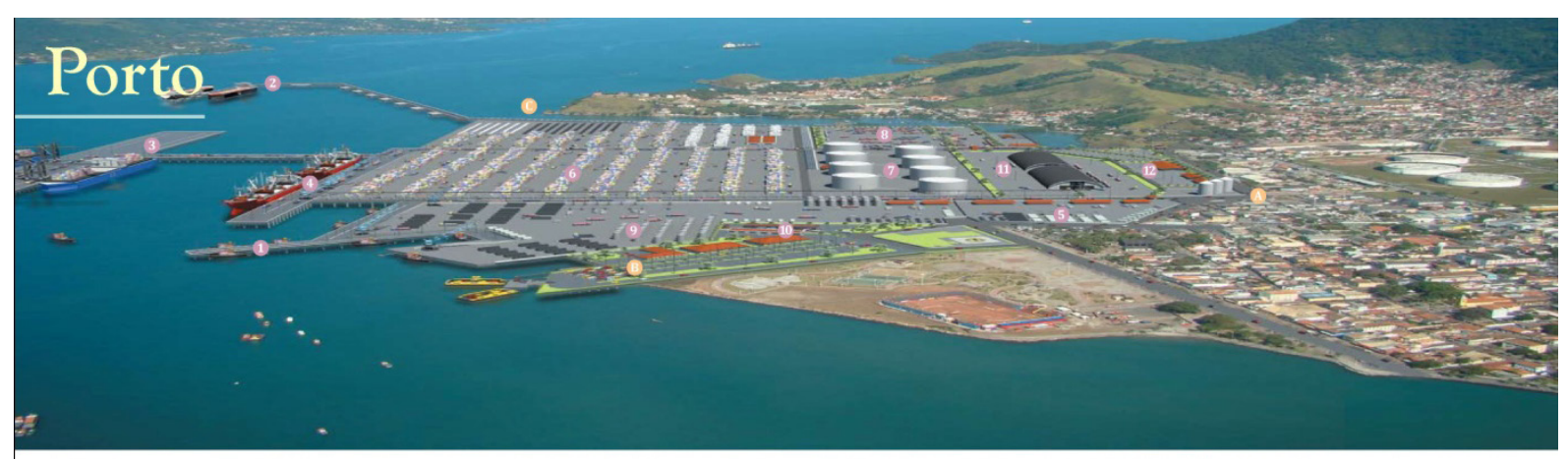

Fonte: Plano Integrado Porto Cidade • PIPC SÃO SEBASTIÃO - SP (2009).

Figura 34 - Proposta de ampliação do porto comercial de São Sebastião. Cenário para 2030

Há indícios de que mais uma vez um EIA-RIMA, agora o do empreendimento de ampliação do porto comercial, será insuficiente como avaliação dos reais impactos ambientais enquanto busca de sustentabilidade urbana para São Sebastião e região.

A Prefeitura Municipal de São Sebastião, responsável pelo planejamento da cidade, em nenhum momento colocou em discussão que tipo de ampliação do porto seria mais adequado para a cidade e seu centro histórico, ou considerasse outra configuração e característica de funcionamento, onde a ênfase não estivesse na carga de contêineres.

Podemos afirmar que faltou uma discussão mais ampla, de qual seria o porto mais adequado para São Sebastião, considerando as especificidades deste território, sua capacidade de suporte e seus verdadeiros efeitos, calculados através de simuladores urbanos, que demonstram matematicamente, a curto, médio e longo prazo, os prováveis efeitos das políticas de uso do solo e de transportes, articulados aos efeitos sociais, econômicos e ambientais. 


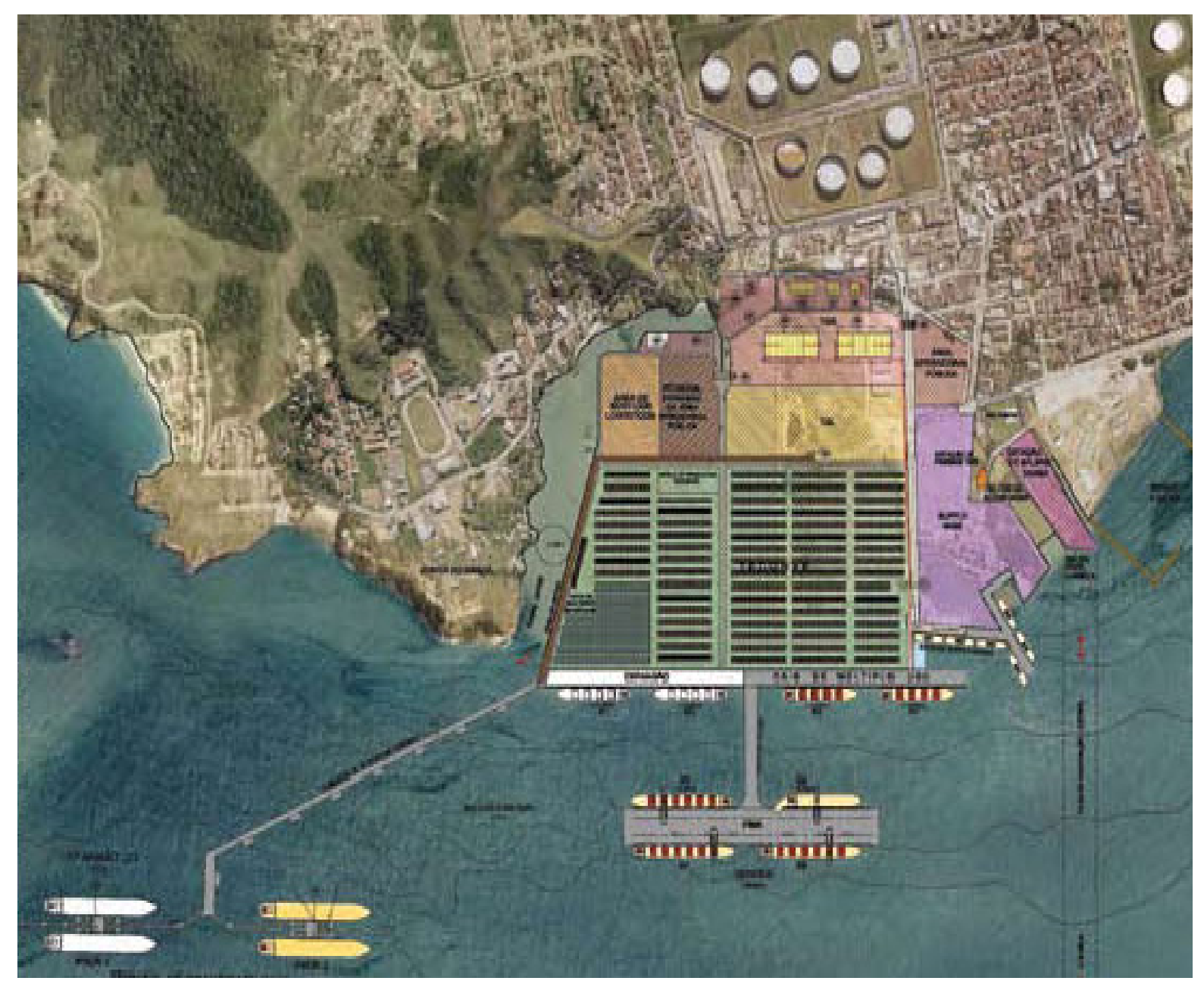

Fonte: Plano Integrado Porto Cidade • PIPC SÃO SEBASTIÃO - SP (2009).

Figura 35 - Proposta de ampliação do porto comercial de São Sebastião. Cenário para 2030

Faltou também projetos que desenhem a interface da cidade com o porto, que não sejam apenas muros e gradis proposto pelo empreendedor e confirmados pelo EIA-RIMA, mas que exijam espaços e usos públicos com definiçôes e compromissos antecipados, para que o empreendedor também seja responsável por viabilizar e contribuir na gestão de uma articulação equilibrada, de fato, entre porto e cidade.

A Figura 36 apresenta o processo de transformação da região do porto comercial e a pouca articulação com a cidade, entre os anos de 1962 à 2009, bem como o projeto de ampliação e cenário pretendido para 2030, que agravará ainda mais a ruptura do tecido urbano com sua zona costeira. 
1962

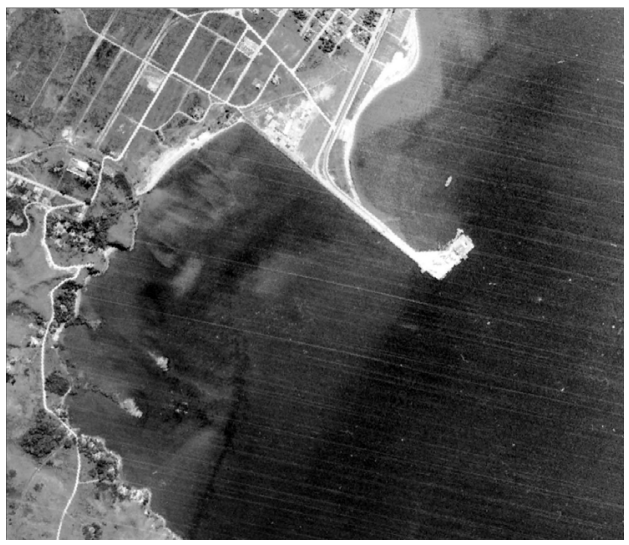

1987

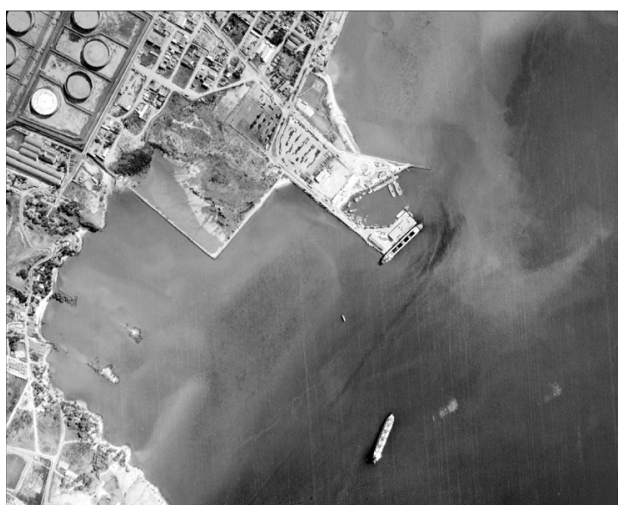

2005

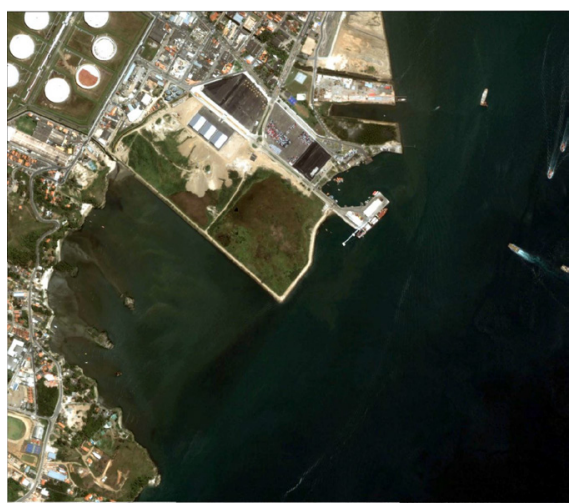

2030
1972

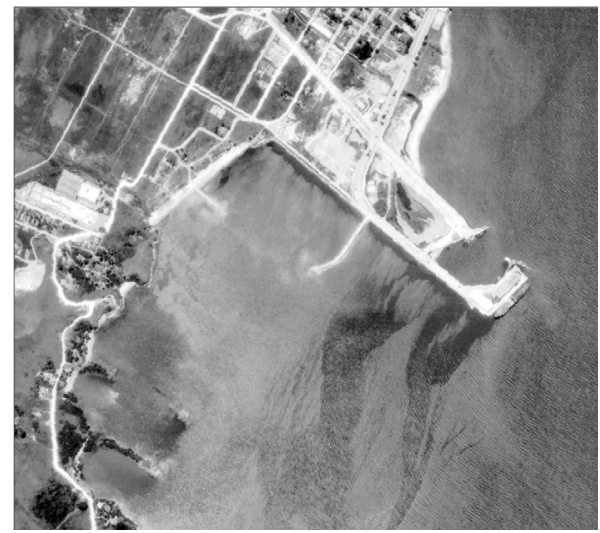

1994

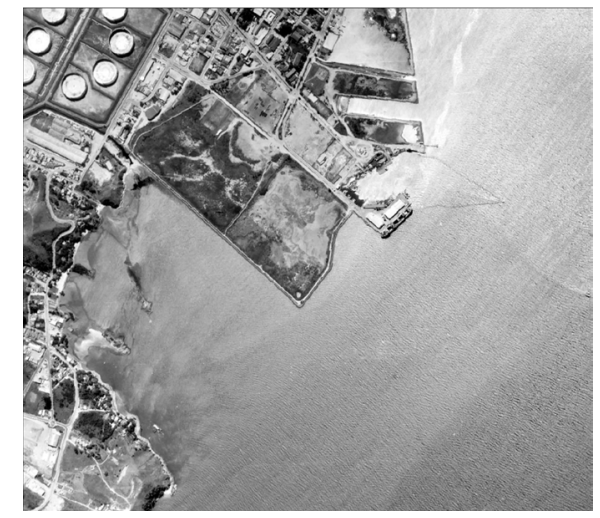

2009

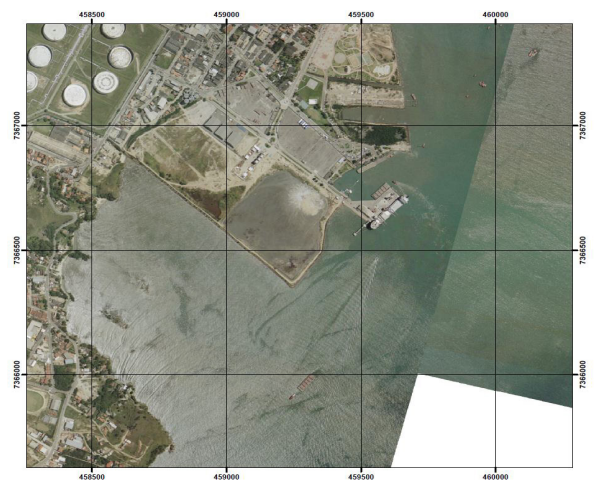

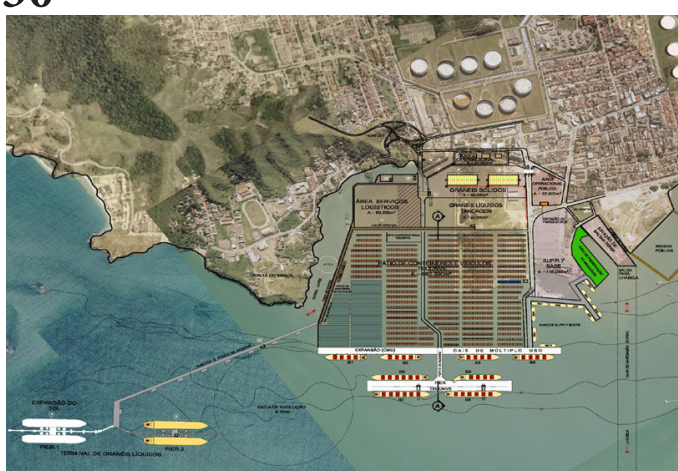

Fonte: Audiência Pública Ilhabela, 2011.

Figura 36 - Processo de transformação da região do Porto de São Sebastião, período 1962 a 2030 


\section{CAPÍTULO IV}

Plano de Costas para a cidade de Barcelona

A recuperação da faixa metropolitana da cidade de Barcelona 


\section{PROPOSTA DE ORDENAÇÃO DA ZONA COSTEIRA METROPOLITANA DE BARCELONA}

$\mathrm{E}$ ste capítulo tem por objetivo apresentar o processo de elaboração do Plano de Costas de Barcelona em 1986, responsável pelo início do processo de recuperação da faixa litorânea metropolitana, e compreender a importância da definição de um outro modelo de ocupação territorial, com participação pública, que estabeleceu um novo planejamento integrado para este território, altamente impactado até a década de 1980, e que impedia a cada dia mais o acesso público às frentes marítimas.

O plano considerou $40 \mathrm{~km}$ de faixa litorânea como área de estudo e um local de especial interesse geográfico que necessitava de diretrizes especificas e valorizasse as condições exclusivas deste território, com recuperação, desenvolvimento e continuidade da paisagem costeira. O objetivo era reconstruir uma nova fachada marítima.

Para a elaboração do Plano de Costas, a equipe responsável levantou e pesquisou os diversos trabalhos realizados anteriormente bem como, ideias, sugestôes, outros planos e as próprias diretrizes do Plano Geral Metropolitano (PGM) de 1976 para a costa (Figura 37).

A intenção era ter um amplo conhecimento das soluções e caminhos já percorridos para poder contribuir com soluções efetivas e alcançar os objetivos desejados, a verdadeira abertura urbana em direção ao mar.

Os Jogos Olímpicos de Barcelona, em 1992, tiveram importância fundamental na implantação do Plano de Costas. O evento foi a grande oportunidade para acelerar as reformas urbanas da cidade na recuperação e renovação de sua frente marítima, que de uma forma ou outra já estavam previstas.

A escolha da cidade como sede dos Jogos antecipou a construção de vários projetos urbanos, inicialmente atendendo às necessidades olímpicas e posteriormente a cidade de Barcelona.

Todas as propostas urbanas sugeridas foram estudadas pelo Plano de Costas, que estabeleceu metas a serem alcançadas e procurava recuperar prioritariamente algumas áreas costeiras da cidade $\mathrm{e}$ resolver questões urbanas fundamentais, como habitaçōes nas frentes urbanas litorâneas (Montgat, Badalona, Sant Andrià de Besòs e Barcelona, com a construção da Vila Olímpica - Nova Icària), conexōes mar/montanha, consolidação do parque litorâneo Del Lobregat e renovação de infraestruturas e diversos equipamentos urbanos, como a ampliação do Porto de Barcelona.

A construção do Porto Olímpico, na Carles I - Avenida Icària, foi o exemplo de uma proposta que evoluiu para atender às questôes olímpicas (sede das competiçôes à vela) e depois passaria a funcionar como importante equipamento urbano, uma nova centralidade, fundamental para o sucesso do bairro Nova Icària. 


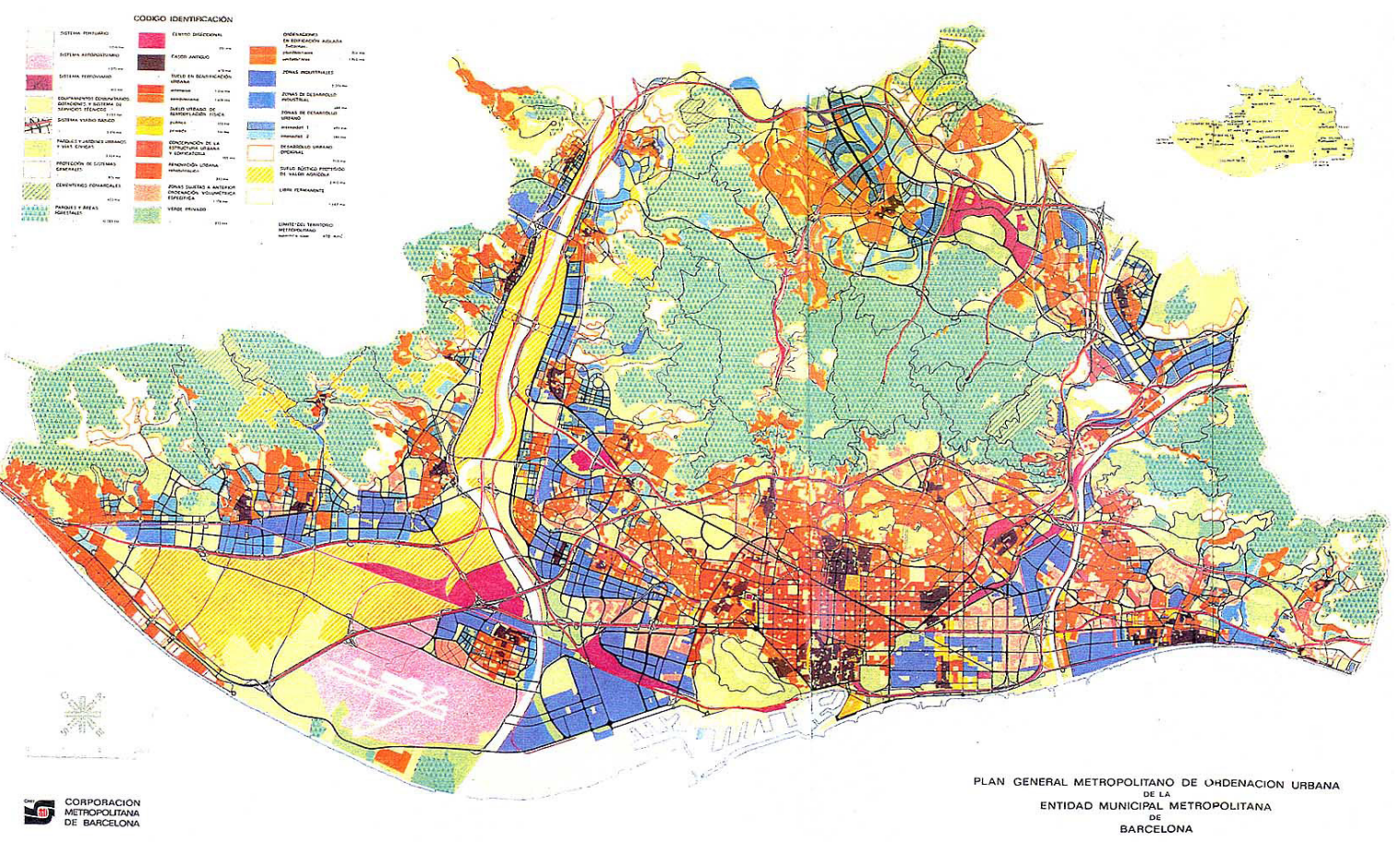

Fonte: Plano de Costa (1986).

Figura 37 - Plano Geral Metropolitano - reprodução do mapa editado pela Corporació Metropolitana de Barcelona, 1976

O novo porto passaria a simbolizar o objetivo do Plano de Costas, o da abertura das comunidades urbanas em direção ao mar, além de promover revitalização urbana com desenvolvimento econômico e social.

Ao mesmo tempo em que era desenvolvido o Plano de Costas, a cidade de Barcelona, através do Serveis de Planejament de l'Ajuntament (Serviço de Planejamento Municipal), coordenado pelo seu diretor, o arquiteto Joan Busquets, utilizava a ocasião do evento olímpico para também desencadear o início da renovação urbana em dez setores da cidade (Figura 38), considerados potenciais áreas de novas centralidades. Importante destacar que os setores 5 e 6 estão diretamente ligados à recuperação da zona costeira.

\subsection{Desenvolvimento do Plano de Costas}

$\mathrm{O}$ Plano Geral Metropolitano (PGM-1976) foi a referência ao desenvolvimento do Plano de Costas, cujo objetivo era valorizar a frente marítima a partir do caráter específico da paisagem costeira e de sua continuidade, desde o município de Sitges, passando por Barcelona e indo até o município de Montgat. 


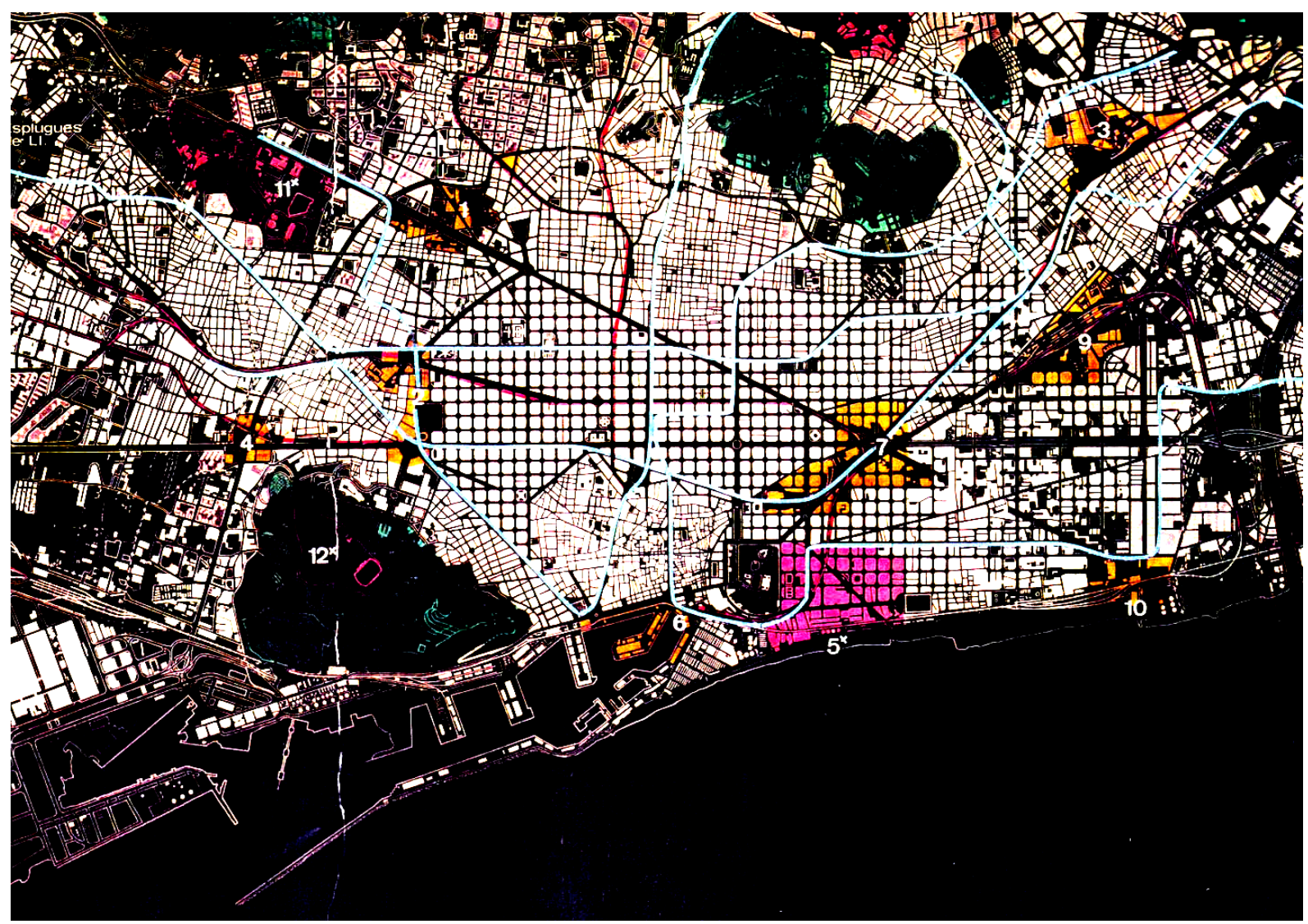

Fonte: Àrees de Nova Centralitat (1987).

Figura 38 - Novas centralidades: dez setores com propostas para requalificação destas áreas Legenda:

1 - Diagonal - Sarrià

2 - Carrer Tarragon.

3 - Renfe - Meridiana

4 - Plaça Cerdà

5 - Carles I - Av. Içaria

6 - Port Urban

7 - Plaça de les Glories

8 - Vall d'Hebron

9 - Sagrera

10 - Diagonal

Em 1967 foi elaborado o primeiro plano para a costa metropolitana da cidade de Barcelona, numa tentativa de renovação urbana, através do Plan de La Ribeira (Plano da Ribeira), que pretendia recuperar a fachada litorânea com uma proposta de uma zona residencial de alto luxo. Este plano causou grande resistência popular, pois apesar de atender os desejos da abertura de Barcelona ao mar, utilizava como instrumento de planejamento, a especulação imobiliária. Nessa época, a Associação de Moradores de Poble Nou e diversas entidades da sociedade civil resolveram organizar um concurso público que se efetivou em 1971. O objetivo era obter um plano alternativo, chamado de contraplano, vencido pelo arquiteto M. de Sóla Morales. Ele propunha manter o máximo de áreas livres ao longo da faixa costeira e concentrar em determinados locais as edificações. 
Apesar dos esforços na busca de alternativas para resgatar o valor da faixa litorânea dentro do território catalão, apenas em 1983 é retomada a ideia desta recuperação através do Plano de Costas, coordenado pelo Arquiteto Lluis Cantallops Valeri, desenvolvido entre 1983 e 1986.

$\mathrm{Na}$ zona costeira de Barcelona estavam localizadas as grandes infraestruturas urbanas que colocavam toda a área metropolitana em funcionamento, como os aeroportos, ferrovias, instalações de saneamentos, sistemas viários, portos, marinas, espaços para lazer, equipamentos específicos e áreas de preservação, formando o conjunto de espaços necessários a qualquer grande cidade. Porém, o processo de ocupação destas áreas pouco considerou os impactos causados no meio ambiente e em sua frente marítima.

O Plano de Costas procurou conhecer com profundidade a faixa territorial em estudos (Figura 39) através do entendimento da situação da época, previsões, capacidade de transformação e possíveis desenvolvimentos, a fim de poder projetar alternativas e cenários futuros aos novos espaços públicos. Os trabalhos levaram em consideração as problemáticas existentes e as características específicas de cada setor para que as propostas sugeridas se adaptassem ao modelo desejado nos $40 \mathrm{~km}$ de costa, entre as cidades de Sitges, Castelldefels, Gavà, Viladecans, El prat de Llobregat, Barcelona, Sant Adrià de Besòs, Badalona e Montgat.

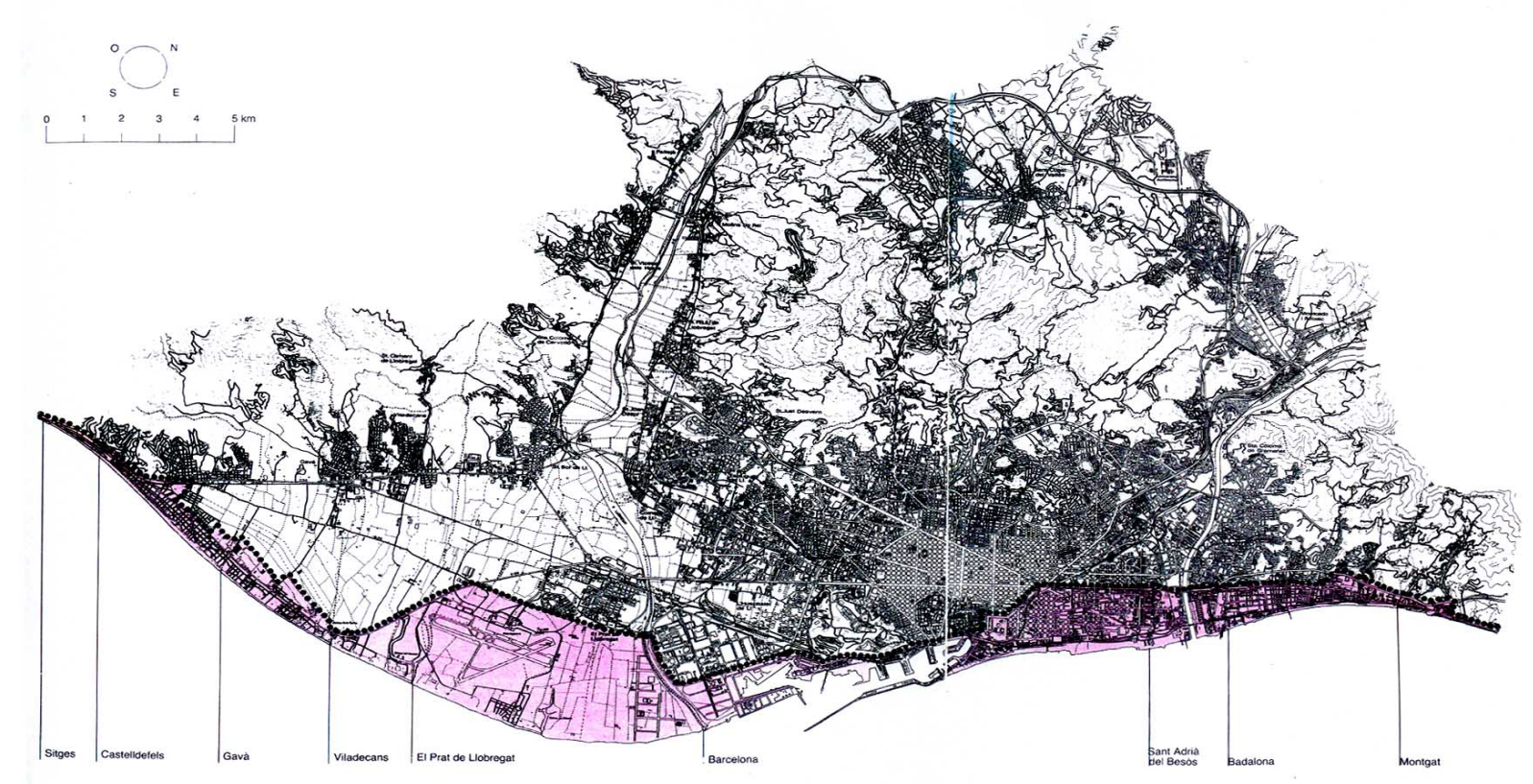

Fonte: Plano de Costas (1986).

Figura 39 - Área que o Plano de Costas contempla, deste o município de Sitges até Montgat

As propostas ordenaram com alto grau de detalhamento áreas residências, equipamentos, parques, passeios marítimos e espaços abertos, verificando e comparando alternativas de possíveis ocupações da zona costeira. 
As intervenções sugeridas, consolidadas nos documentos dos Critérios Objetivos e Soluções Gerais de Planejamento (COSGP), estabeleceram a possibilidade de atuações ao longo do tempo através dos agentes públicos e privados, com revisões e atualizações no plano para responder às condiçõos imprecisas de execução, mas sem renunciar aos objetivos desejados.

As propostas pontuais respeitaram a seguinte ordem de trabalho: descrição dos limites da área de intervenção, situação atual em 1983, estrutura da propriedade, objetivos desejados e proposta de planejamento com a ordenação espacial.

Os projetos urbanos desenvolvidos foram espacializados através de desenhos, considerados instrumentos necessários e importantes nas transformações reais, para que estivessem orientadas segundo diretrizes previamente determinadas.

Os desenhos ${ }^{29}$ permitiram gerar bases importantes ao amplo debate sobre as possibilidades e opções de ocupação da faixa litorânea pretendida para o futuro.

O plano considerou duas questôes fundamentais: a identificação das atuações previstas, verificando as transformações e os potenciais da zona costeira, e a aprovação da população às modificações sugeridas, através das informações e dos debates públicos sobre os objetivos coletivos desejados.

Até a década de 1980 eram poucos os pontos que permitiam o acesso direto da população às frentes marítimas metropolitana de Barcelona. A maior parte das áreas costeiras, inclusive as próprias praias, estavam comprometidas com a presença de grandes infraestruturas (Figura 40), como o porto comercial, o aeroporto, as rodovias e principalmente as ferrovias (Figura 41), que, quando implantadas, estimularam ainda mais a vinda de grandes indústrias ao setor litorâneo.

A faixa litorânea restante, não afetada pela presença das grandes infraestruturas, foi ocupada por complexos turísticos e diversas residências de verão. De certa forma, funcionavam também como barreiras, já que os usos privilegiavam uma pequena parcela da população. As somas destes elementos praticamente inviabilizaram os acessos e a utilização pública da costa metropolitana de Barcelona.

O Plano de Atuação, editado pela Direção Geral de Portos e Costas do Ministério de Obras Públicas e Urbanismo (MOPU), foi fundamental ao plano específico de Barcelona. Ele definiu qual a política a ser adotada na zona costeira espanhola entre 1983 a 1990 e demonstrava a filosofia de um Ministério com capacidade legal e econômica para intervir nas questôes relativas à costa.

O Plano de Atuação era composto por quatro programas, sendo que os dois primeiros influenciaram diretamente (a curto e médio prazo) a nova ordenação urbana da zona costeira de Barcelona. O programa $n^{\circ} 1$ definia as questóes normativas de anteprojeto a uma nova Lei de Costas, com uma série de normas promulgadas ou de próxima promulgação.

${ }^{29}$ Os desenhos informavam as possíveis soluçōes como: volumetrias, sistema viário (novos acessos), arborização, passeios de pedestre, equipamentos urbanos, parques, reservas naturais, ampliação do porto comercial, novos portos de recreio, parcelamento do solo, entre outras soluções. 


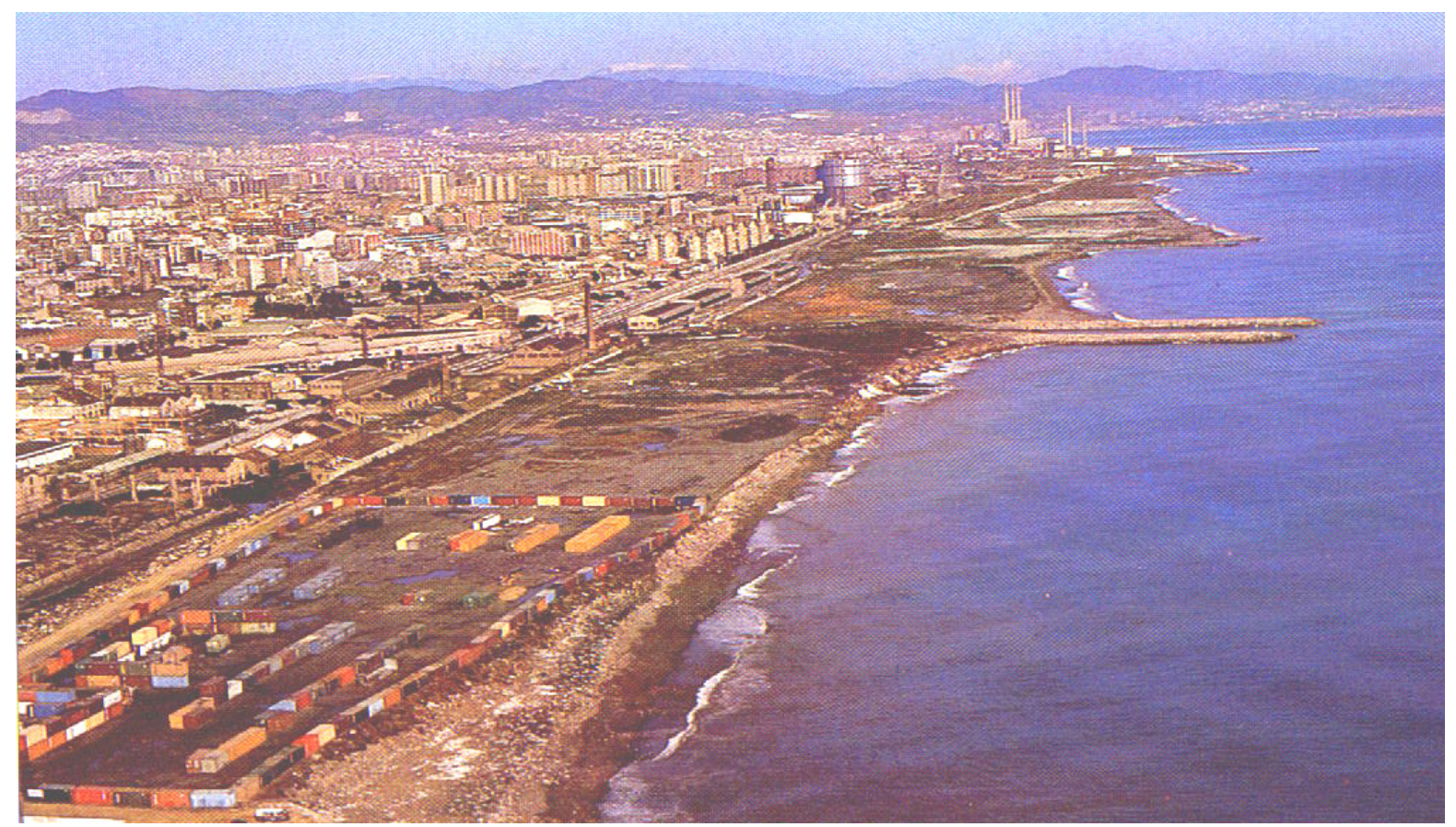

Fonte: Plano de Costas (1986).

Figura 40 - Frente marítima de Poblenou na década de 1980

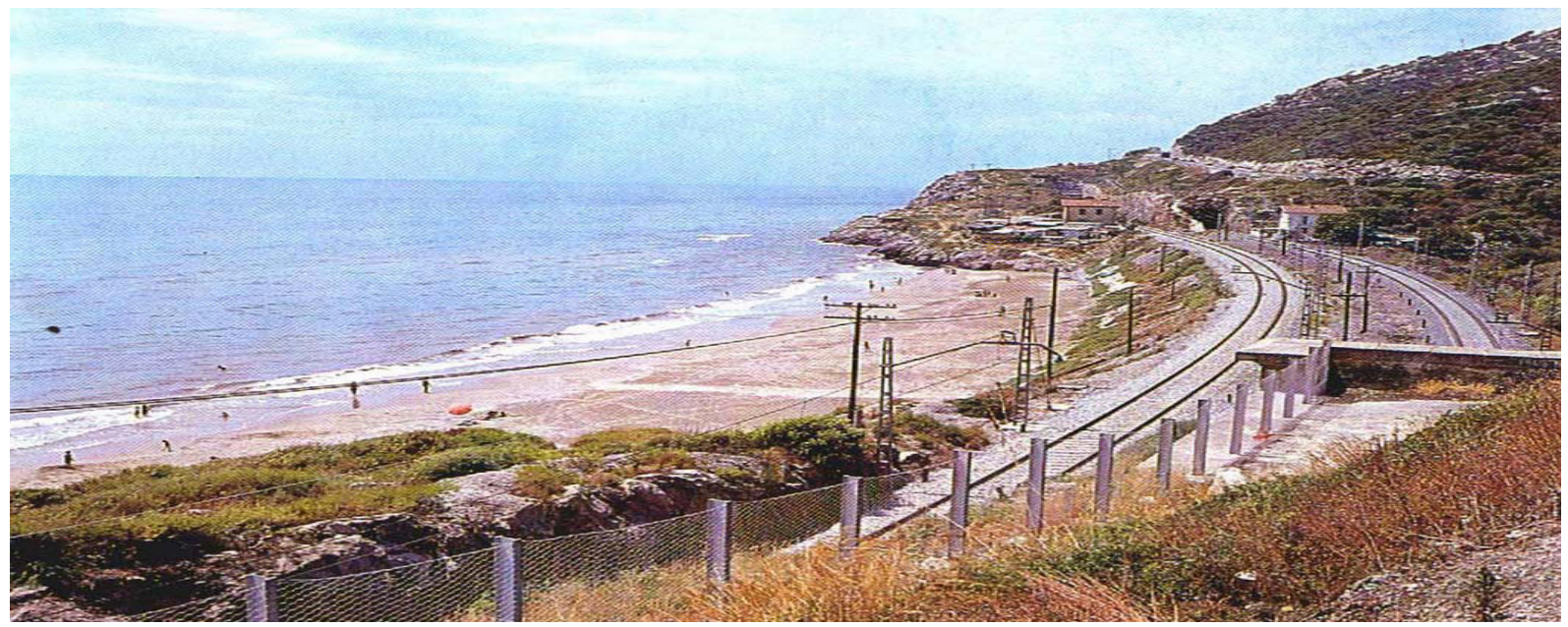

Fonte: Plano de Costas - 1986, p.23.

Figura 41 - Garraf, município de Stiges - barreira ferroviária

$\mathrm{O}$ anteprojeto de lei procurava preservar o meio ambiente a favor do domínio público, com redefinição e ampliação do domínio marítimo terrestre (território de interface entre mar e terra) de acordo com a realidade física atualizada do território, através da desafetação e aquisição de novas áreas, do estabelecimento de zonas de proteção e de influência (faixa de servidão) e da agilidade e eficácia prática nos procedimentos preventivos e sancionadores.

As principais normas promulgadas sugeriam para a zona costeira $10 \%$ de áreas verdes (do solo urbanizado) como espaço coletivo e limítrofe com o domínio público e no máximo 25 edifícios por 
hectare, até três pavimentos. Aconselhava-se, ainda, qualificar estes espaços limítrofes como solos não urbanizáveis e de especial proteção, definidos como zonas de conservação da natureza ou parques litorâneos. As normas estavam orientadas a dotar a zona costeira de acessos públicos adequados e suficientes para o uso das praias.

O programa $n^{\circ} 2$ considerava necessárias ações que deveriam ser de curto prazo, com soluções a problemas pontuais, adotando técnicas menos agressivas possíveis e preservando ao máximo as praias. As de médio prazo, com um plano de gestão adequado à defesa de grandes áreas costeiras, pretendia manter e recuperar zonas de valor ambiental.

$\mathrm{O}$ programa $\mathrm{n}^{\circ} 3$ teria a responsabilidade pela montagem do banco de dados oceanográficos e do clima marítimo. $\mathrm{O}$ programa $\mathrm{n}^{\circ} 4$ era responsável especificamente pela proteção das praias e vigilância da costa espanhola.

Os quatro programas do Ministério de Obras Públicas e Urbanismo (MOPU) tinham como meta redefinir e adaptar os tecidos urbanos costeiros a fim de garantir a verdadeira abertura das cidades ao mar em toda costa espanhola.

Para alcançar este objetivo em Barcelona, o Plano de Costas considerava a necessidade do entendimento e de intervenção na escala territorial, compreendendo que o tecido metropolitano funcionava como um organismo inter-relacionado, e não como soma de partes, portanto, deveria ser pensado no seu conjunto para evitar conflitos e reduzir incompatibilidades definitivas entre as diversas funções que necessitavam ter o seu lugar no espaço urbano.

Qualquer proposta sugerida na faixa litorânea teria seu rebatimento direto no interior do território, por isto, o plano estabeleceu limites de influência (diretos e indiretos). A partir daí, o Plano Geral Metropolitano passaria a ser responsável pelos estudos necessários. Para o desenvolvimento dos trabalhos foram levados em consideração os objetivos da abertura dos tecidos urbanos em direção ao mar, já determinados pelo PGM, principalmente em relação às distribuições espaciais previamente sugeridas.

As propostas feitas pelo Plano de Costas procuravam reestruturar detalhes dos tecidos urbanos costeiros e redefinir pontualmente o uso do solo, para estabelecer a nova relação urbana com o mar. Além disto, propunha efetuar estudos morfológicos constantes na unidade fisiográfica a qual pertence a Costa Metropolitana de Barcelona, para monitorar o meio ambiente.

A seguir, veremos os projetos e desenhos elaborados e as ações propostas para as obras náuticas, aeroporto, ferrovias, sistema geral viário, sistema geral de serviços técnicos, sistema geral de equipamentos comunitários e sistema geral de parques e jardins urbanos (Figura 42, 43 e 44). 


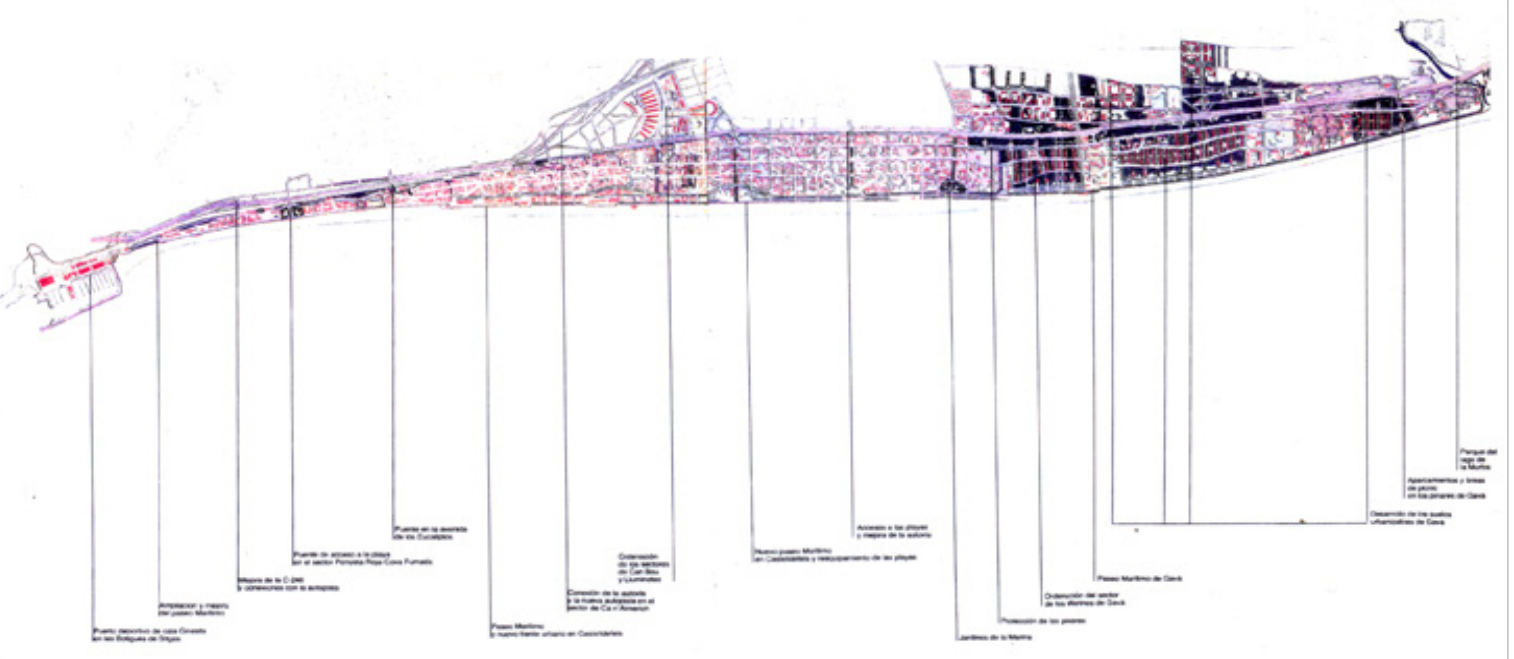

Fonte: Plano de Costas (1986).

Figura 42 - Frente marítima entre os municípios de Sitges (les Boutigues) até Castelldefels e Gavà

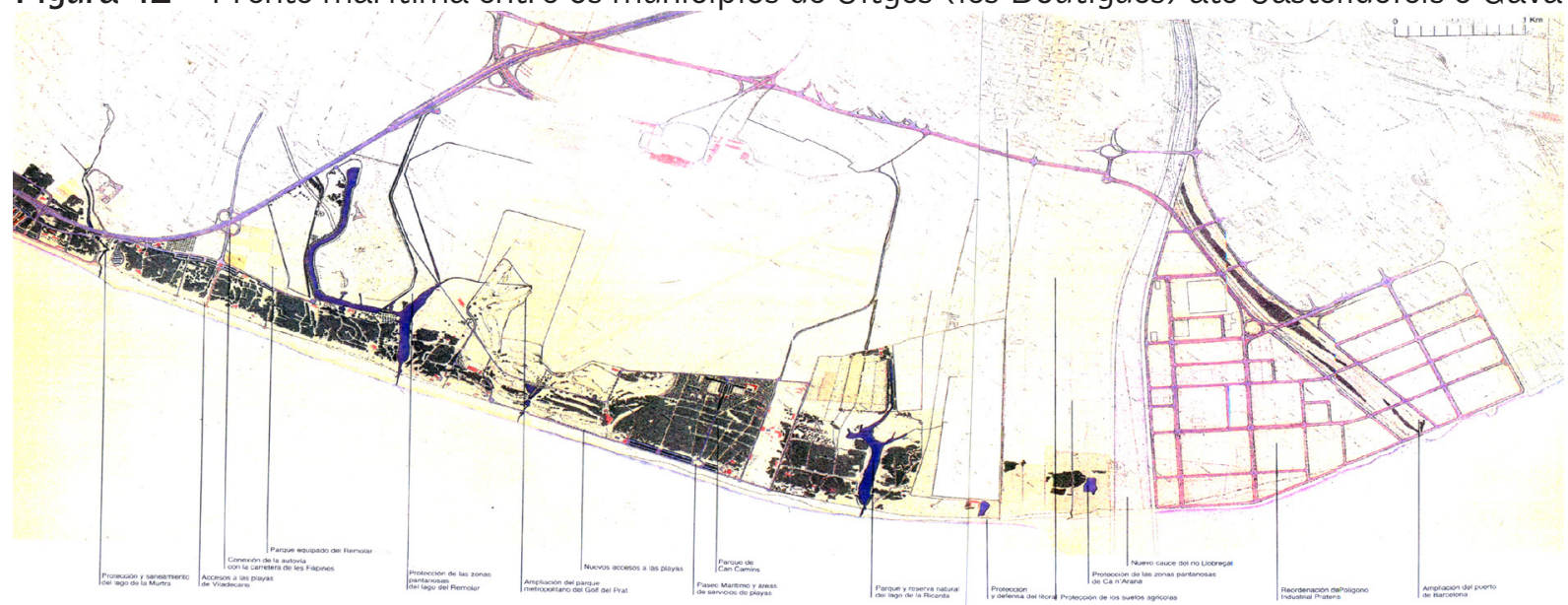

Fonte: Plano de Costas (1986).

Figura 43 - Frente marítima entre os municípios de Villadecans até El Prat del Llobregat

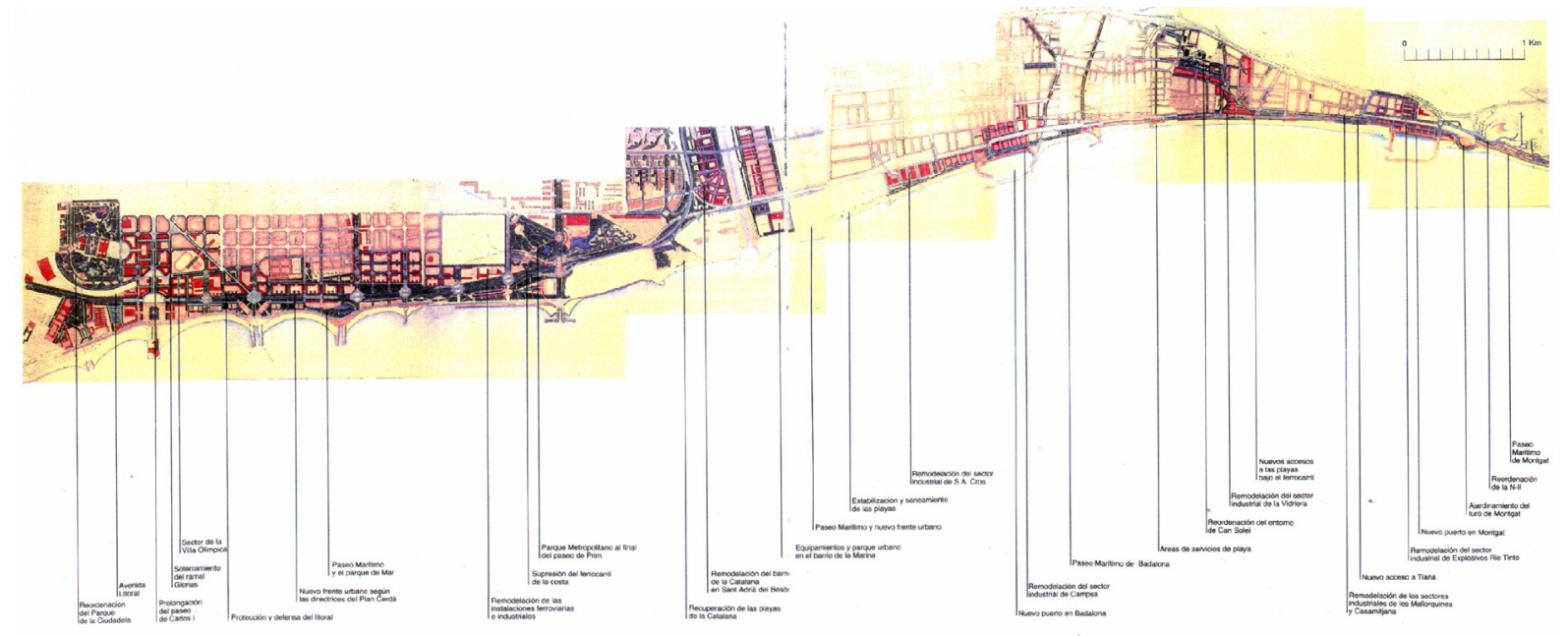

Fonte: Plano de Costas (1986).

Figura 44-Frente marítima entre os municípios de Barcelona, Sant Adrià de Besós, Badalona, até Montgat 


\subsection{Obras náuticas}

$\mathrm{O}$ s estudos demonstraram que a costa metropolitana de Barcelona pertence a um único setor fisiográfico, ou seja, são áreas que sofrem as mesmas influências dos fenômenos naturais.

Em suas costas abertas, as correntes de areia são paralelas à praia e o sentido predominante, neste caso, é de noroeste para sudoeste.

É necessário compreender as praias como formaçōes sedimentares móveis, constituídas por pequenas partículas de origem terrestre, que se deslocam ao longo do litoral por ação das ondas do mar. A areia se move no sentido das ondas predominantes, como um verdadeiro "rio de areia”, paralelo à costa e alimentando-se de materiais procedentes dos rios, das chuvas, erosões das áreas costeiras que são depositados nas próprias praias ou em bacias submarinas, fechando um ciclo.

O ciclo sedimentar determina uma unidade fisiográfica, que deveria ser amplamente avaliada e compreendida. Sem as análises globais e detalhadas dos fluxos de correntes, das estruturas náuticas existentes e novas intervençôes marítimas, o equilíbrio dinâmico costeiro estaria comprometido, pois desencadearia novos processos erosivos em determinadas áreas.

O Plano considerou que os processos erosivos das faixas costeiras e as alterações na estabilidade das praias eram provocados pelas barreiras artificiais que interceptam as correntes de areia paralelas às praias (Figura 45), construções que causam obstáculos e oscilações naturais das praias, destruições das dunas formadas atrás das praias e diminuição das reservas naturais de areia.

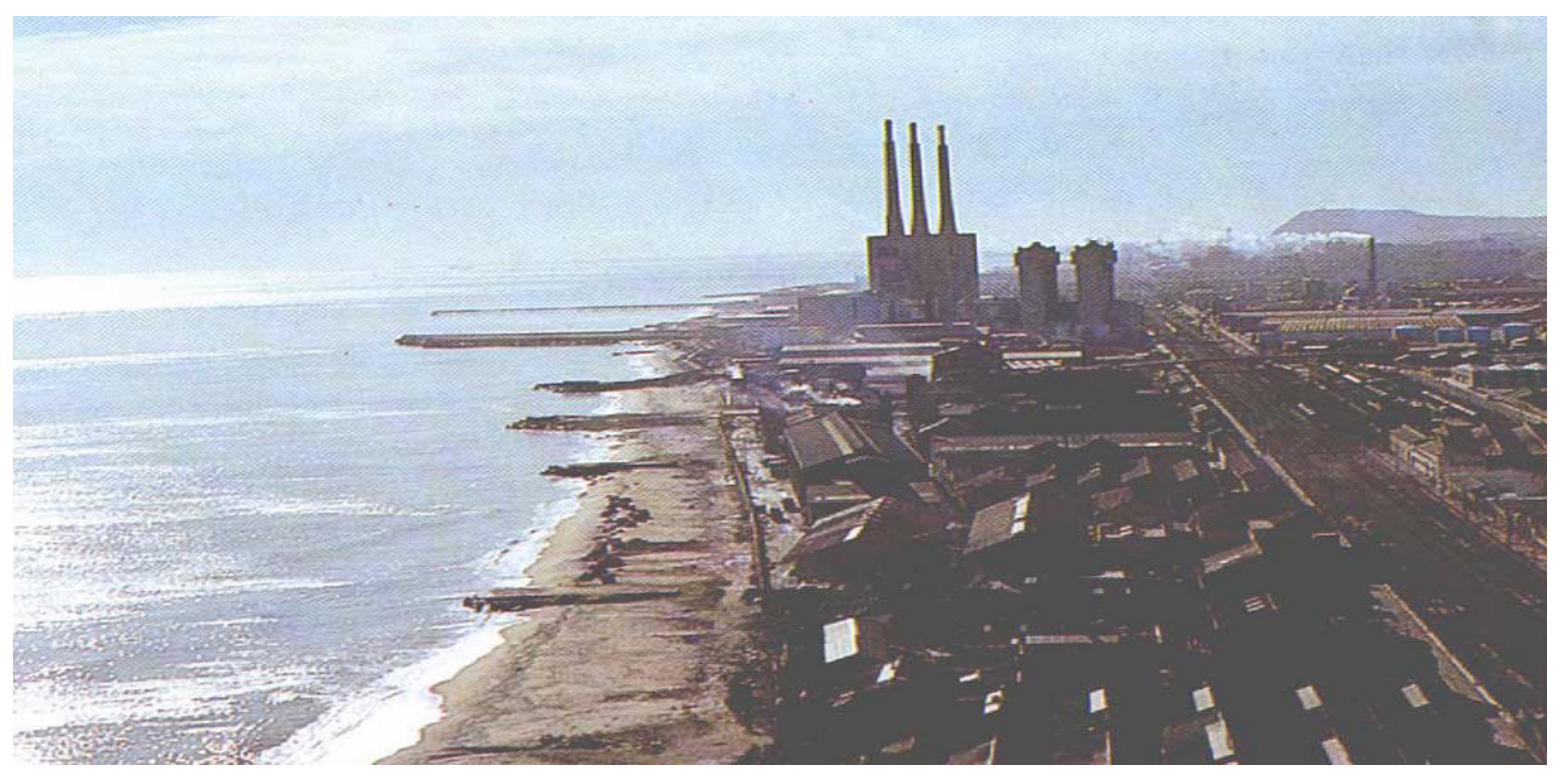

Fonte: Plano de Costas (1986).

Figura 45 - Zona industrial de Badalona 
Quando se constrói uma obra marítima que interrompe de forma constante os movimentos e fluxos da areia, há um acúmulo de material tanto ao noroeste quanto ao sudoeste. Este procedimento certamente provocara modificações ambientais.

A grande obra construída na Zona Costeira Metropolitana de Barcelona foi o porto comercial, que sempre funcionou como verdadeira barreira às correntes e fluxos marítimos.

A interrupção destes fluxos ao longo dos anos causaram acúmulo de areia no setor norte do porto, o que acabou por modificar a linha costeira. $\mathrm{O}$ impacto foi tão grande que possibilitou, no século XVIII, a utilização e ocupação da área ganha do mar, onde foi construído o bairro de Barceloneta.

Os espigóes artificiais construídos perpendicularmente à costa para proteger e promover a recuperação das praias prejudicadas pelas interferências de outras estruturas náuticas também funcionavam como barreiras e impediam as correntes marítimas de circular naturalmente.

Constatou-se que a maior parte das obras foram inúteis, apenas mudaram o problema de lugar e as alterações provocadas foram gravíssimas, tanto na qualidade ambiental assim como na estética de todo o território costeiro.

O Plano recomendava às novas obras construídas dentro d'água a utilização de técnicas menos agressivas ao meio ambiente, para garantir proteção e recuperação das praias. Uma das soluções também proposta era a realimentação artificial de areia às correntes marítimas.

A proliferação de pequenos portos desportivos, como o Porto de Arenys (Figura 46), também causaram graves problemas nos fluxos de areia. A Marinas de Balís, Premià de Mar e a Marina Masnou provocaram consideráveis modificações na linha de costa, principalmente nas praias de Maresme e Montgat, que desapareceram completamente.

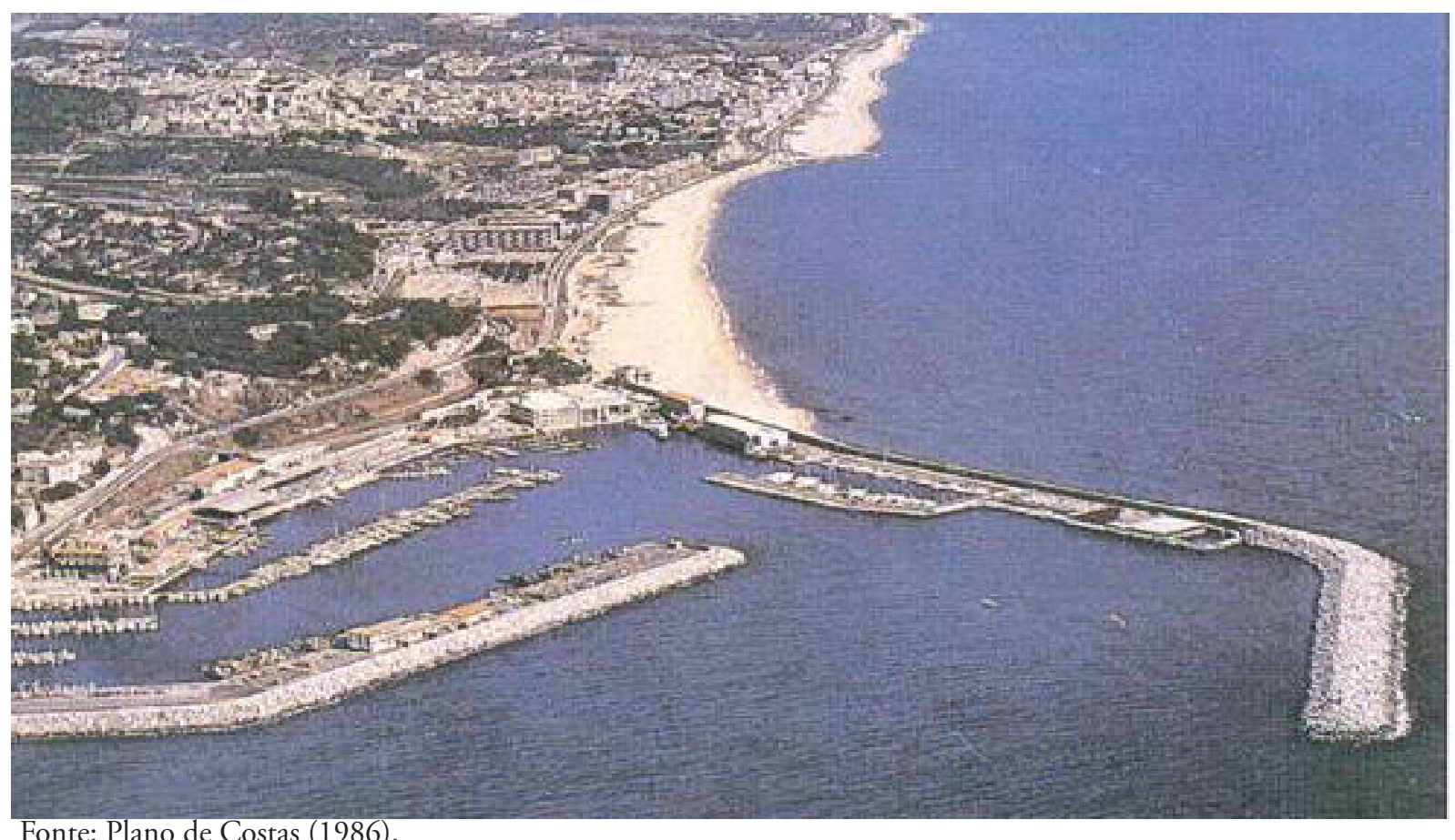

Fonte: Plano de Costas (1986).

Figura 46 - Porto de Arenys: interrupção das correntes de areia do NE-SO 
O Plano considerava que obras marítimas deveriam alterar o mínimo possível a paisagem natural para recuperar sua qualidade estética ambiental, e para isso era necessário levar em consideração nos custos das obras náuticas as superfícies de praias a serem recuperadas, além de empregar soluçóes dinâmicas ao longo tempo, pois grandes intervenções pontuais são mais caras e de difícil modificação posterior.

Propôs evitar também construções responsáveis por obstáculos às oscilações naturais das correntes marítimas e que poderiam interromper o movimento de areia entre mar e terra, através das marés altas e baixas.

Além disto, o plano indicava restringir as construções dos passeios marítimos às zonas urbanas consolidadas, com o objetivo de determinar o limite até onde os edifícios deveriam se aproximar da faixa de areia e também não permitir a destruição das cadeias de dunas formadas atrás das praias, evitando a extração de areia e de construções sobre elas, ainda regulamentando sobre a utilização das dunas como espaços recreativos de alto valor paisagístico.

A Zona Costeira Metropolitana de Barcelona sofreu grandes modificações com as diversas obras executadas ao longo da costa. As mudanças nas direções das correntes marítimas alteraram os fluxos de areia e dos sedimentos.

O perfil litorâneo adquiriu outra configuração, não natural, e os principais fatores que provocaram estas alterações foram a canalização dos rios, retirada de areia ao longo de seus percursos (comprometeu a contribuição de material para as correntes marítimas), a instalações industriais na costa, a interrupção de forma constante dos fluxos de areia vindas do noroeste pela presença do Porto de Barcelona, pressões urbanísticas (cada vez mais intensa no litoral) e a construções de inúmeras barreiras marítimas (diversos espigões transversais para a proteção das praias e grande quantidade de pequenos portos desportivos).

O Ministério de Obras Públicas e Urbanismo (MOPU) previa a possibilidade de recuperar as praias através da regeneração artificial das condiçōes naturais, especificamente para a praia de Maresme, entre o trecho que vai do Porto Premià até a praia de Montgat, em Badalona.

As ações propostas para conseguir praias abertas e com aspecto natural, sem grandes obras e consequentemente de custo reduzido, eram o desmonte de três espigóes ao sul do Porto Premià Del Mar e suprir de forma artificial e periódica a quantidade de areia anteriormente transportada ao sudoeste pelas correntes marítimas.

Os estudos de prospecção feitos entre 1993 e 1996 nos trechos determinados pelo plano foram fundamentais no conhecimento das características do fundo marítimo.

Os resultados das informações levantadas determinaram as propostas e sugestôes, principalmente na estabilização das praias e possíveis locais para construções de novos portos desportivos que não comprometessem os fluxos marítimos 


\subsubsection{Porto de Barcelona}

$\mathrm{O}$

Plano Geral Metropolitano (PGM) de 1976 qualificou os territórios do sistema geral portuário de Barcelona em três zonas:

Zona Marítima Terrestre (ZMT): espaço da costa banhado pelo mar, cujos limites foram na sua maioria definidos entre 1920/1930.

Zona relativa ao porto que inclui o solo sob competência da Junta do Porto de Barcelona e áreas entre a linha que limita a Zona Marítima Terrestre e o interior do Porto, além das possíveis áreas ganhas do mar.

Zona relativa ao entorno do Porto com suas áreas imediatas.

O regime urbanístico destes espaços portuários, propostos pelo Plano Geral Metropolitano, deveria estar compatibilizado à legislação especial vigente, mas, segundo o Plano de Costas, apresentava uma série de deficiências, como: pouca definição da ZMT, defasada e não ajustada à realidade geográfica, predomínio da propriedade privada do solo, usucapião nas concessões de uso, ausência de proteção dos territórios limítrofes, passividade do poder público na questão de extração de areia e ausência de normas para preservação da paisagem e do meio.

O Plano de Costas desenvolveu para o porto estudos até o ano de 2005, que previa fundamentalmente consolidar e modernizar as ofertas portuárias.

Os resultados das avaliaçôes feitas pelo Plano recomendavam as seguintes diretrizes:

- Aumento do calado para barcos de grande tonelada.

- Melhorar a infraestrutura viária de transporte.

- Criar uma zona industrial portuária moderna que permitisse as instalaçôes de atividades econômicas especiais.

- Incrementar a função de feeder (canalizador e distribuidor de mercadorias das grandes companhias para portos menores).

- Portos feeder precisam de grandes superfícies de cais para depositar as mercadorias em trânsito e contêineres, razão para ampliação das áreas do Porto.

- A ampliação exigia a elaboração de estudos adequados sobre os aspectos técnicos, ambientais, jurídicos, econômicos e financeiros.

- Análise das zonas industriais anexas ao âmbito portuário.

O Plano constatou também que o porto possuía baixa proporção de área dedicada ao uso industrial em relação à área de transporte, já que a relação adequada entre áreas de transportes versus áreas industriais (dentro das áreas portuárias) deve variar entre 1:1 e 1:2 (ideal), mas em Barcelona esta relação estava em 1: 0,15. O cálculo demonstrava claramente que o futuro do porto dependeria de sua expansão.

Diversos estudos foram realizados e comprovou-se a real necessidade de novas áreas para evitar 
congestionamentos e permitir que o porto continuasse sendo competitivo nacional e internacionalmente (Figura 47 e Figura 48).

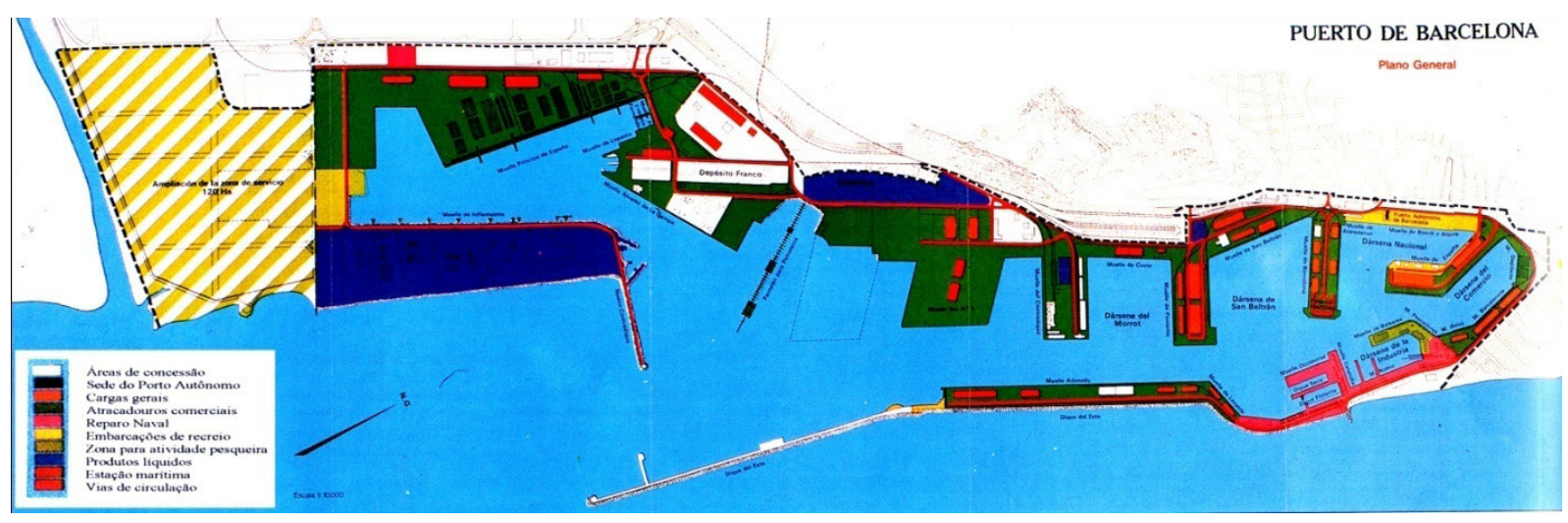

Fonte: Plano de Costas (1986).

Figura 47 - Porto de Barcelona - Plano Geral

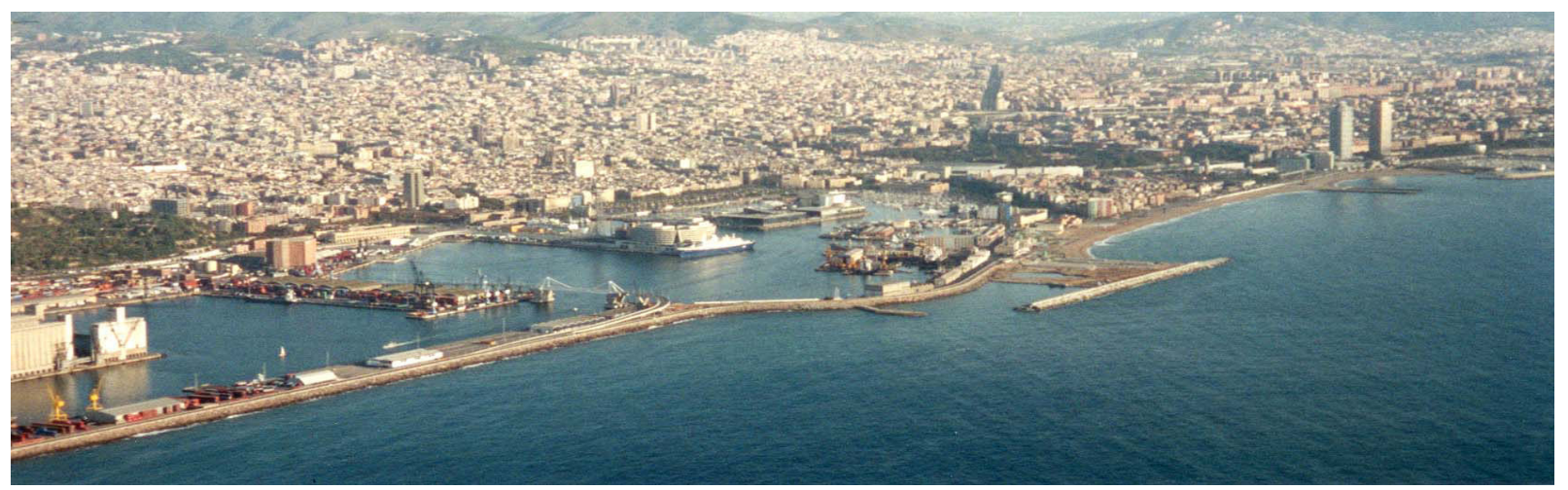

Fonte: José Francisco Xavier Magalhães (2000).

Figura 48 - Porto de Barcelona.

O Porto de Barcelona, que vai de Barceloneta até o rio Llobregat, só possuía uma alternativa para a ampliação de suas áreas, na direção sul. Esta alternativa implicaria no desvio do rio Llobregat, levando a desembocadura do rio a $4 \mathrm{~km}$ da foz natural.

Estudos geomorfológicos sobre o desvio e canalização do rio alertavam para o fenômeno de anulação definitiva de areia transportada até o mar neste ponto da costa, e propunham o desenvolvimento de pesquisas detalhadas para verificar as consequências desta solução. A proposta do Plano de Costas ampliaria as áreas necessárias ao desenvolvimento futuro do porto e ainda evitaria problemas com inundações, erosões dos terrenos portuários e reduções nas profundidades batimétricas próximas à costa.

\subsubsection{Ampliação do Porto Central de Barcelona}

Porto Central de Barcelona concentra a maior oferta logística do sul da Europa em função das conexões com diversos modais de transporte. Em um raio inferior a $5 \mathrm{~km}$, conta com a 
presença de aeroporto, estradas e ferrovias. Esta situação permite que ele seja um importante eixo comercial de transportes e distribuição do Mediterrâneo.

O novo plano para o Porto de Barcelona, entre 1997/2011, analisou a situação atual e as novas exigências do mercado portuário.

Através de um ideal comum, as empresas e instituiçôes da comunidade ligadas ao porto, lideradas pela Autoridade Portuária de Barcelona, definiram metas a serem atingidas para que o porto comercial pudesse ser o mais competitivo possível no século XXI. A estratégia era fazer com que ele se tornasse o primeiro porto logístico do Mediterrâneo com a ampliação de suas intermodalidades, além de aumentar sua capacidade nas distribuiçōes e abastecimento de mercadorias. Para conseguir tais objetivos, o Porto de Barcelona apostava em sua importante localização geográfica e sólida capacidade industrial, comercial e tecnológica.

O crescimento do trânsito de mercadorias em 2001, atingindo os 32 milhôes de toneladas, foi fruto desse trabalho constante, através dos estudos para ampliar sua competitividade com capacidade operativa e dos sucessivos processos de modernização das suas instalações.

O Plano Diretor, para o período entre 1997 a 2011, definiu as possíveis ampliações dentro da atual área portuária:

- Ampliação do dique de Infamables. mais 69,0 hectares.

- Ampliação do dique dos Adosado mais 12,5 hectares.

Após esta etapa, o porto terá realizado todas as obras possíveis dentro do perímetro atual e restaria o início do Plano Delta, para adquirir outras áreas às futuras ampliaçōes.

O Plano Delta é um projeto a ser viabilizado através de investimentos públicos e privados cujo objetivo fundamental é o desvio do rio Llobregat, conforme alternativa sugerida pelo Plano de Costas em 1986.

A proposta pretende levar a desembocadura do rio $2 \mathrm{~km}$ ao sul e permitir a ampliação do porto, conseguindo dobrar as atuais áreas portuárias, chegando a 1.300 hectares de superfícies terrestres.

A solução contempla também a construção do dique sul (4.800 metros de comprimento), a continuidade do dique leste (2.170 metros) e também a melhora da acessibilidade ao porto, com novas redes viárias (autopista del Llobregat), conexōes ferroviárias e ainda a ampliação do aeroporto.

Além da proposta e o sucesso da modernização do Porto Comercial Central, a cidade obteve um grande crescimento no setor relacionado a cruzeiros turísticos.

No ano de 2001 recebeu aproximadamente 650.000 mil passageiros, ${ }^{30}$ sendo que $50 \%$ deles iniciaram ou terminaram suas viagens em Barcelona.

O Porto Urbano pode atender simultaneamente nove cruzeiros marítimos nos seis terminais em funcionamento. Dois deles, com $12.500 \mathrm{~m}^{2}$ de área construída, estão situados no novo centro de

${ }^{30}$ Fonte: Porto de Barcelona, 2002. 
negócios da cidade (Figura 49), localizado no World Trade Center. O projeto, inaugurado em 1999, pertence ao arquiteto Henry N. Cobb, sócio fundador do escritório Pei, Cobb, Fred \& Partners.

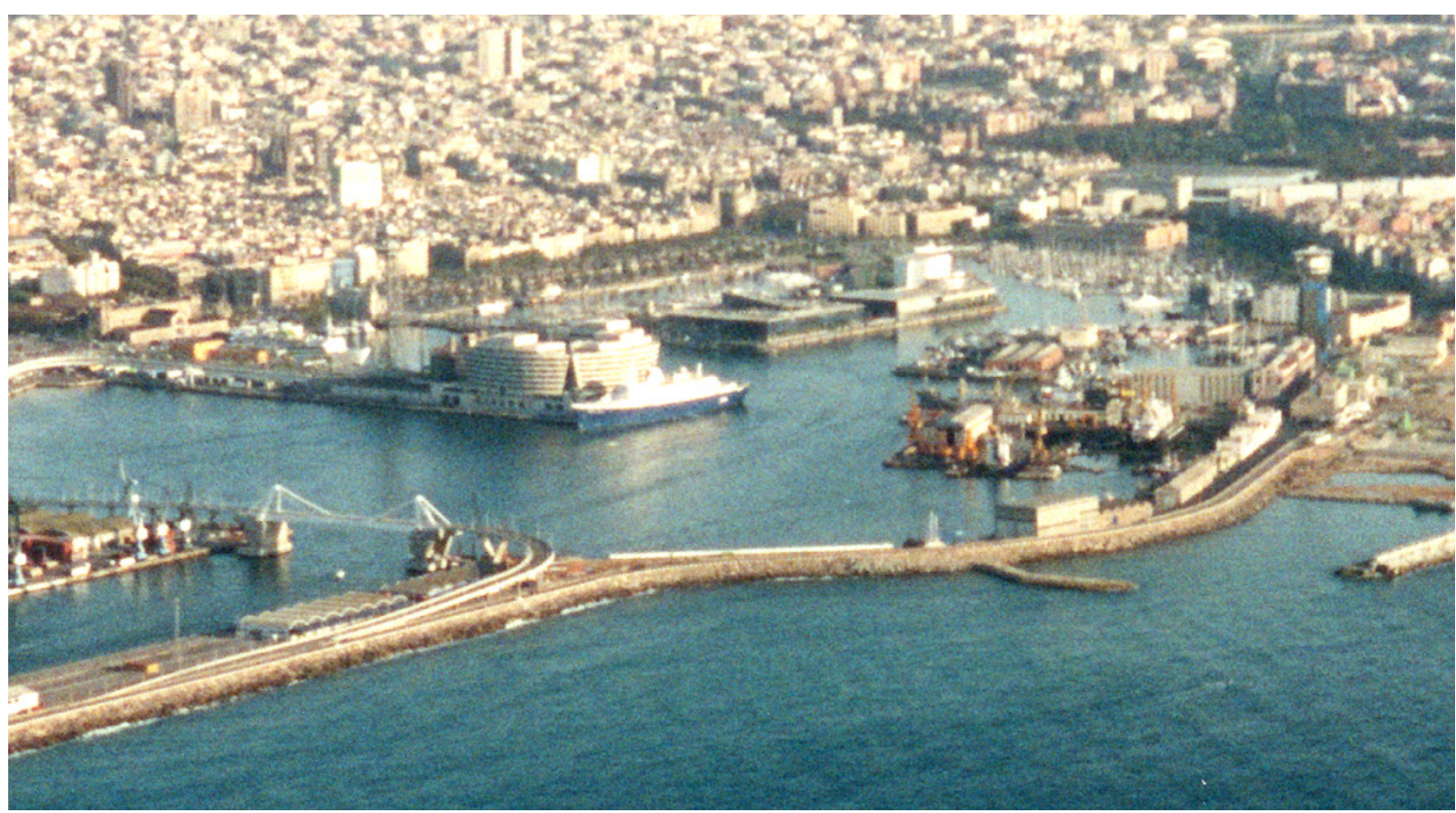

Fonte: José Francisco Xavier Magalhães (2000).

Figura 49 - Porto de Barcelona e o terminal turístico World Trade Center

O complexo do World Trade Center, com $130.000 \mathrm{~m}^{2}$ de área construída, oferece, além do terminal de passageiros, um centro comercial e os mais modernos serviços para os negócios marítimos, portuários e de comércio exterior.

O terminal de passageiros é considerado uma das melhores bases do mundo por dispor das melhores infraestruturas, tanto para os navios quanto para os seus passageiros. ${ }^{31}$

O porto, dentro do programa de requalificação de suas áreas, abre espaço para uma série de atividades destinadas ao lazer da população ${ }^{32}$ e funciona como interface importante na requalificação entre centro histórico e frente marítima da cidade.

As principais atividades instaladas atualmente na área portuária são:

- Maremágnum (comércio, bares e restaurantes).

- Aquarium, Cine Imax e Multicine (8 salas).

- Marina do Porto Velho: previsão para até 2.000 vagas para embarcações.

- Clube náutico e marítimo.

- Museu marítimo e Museu de história da Catalunha.

- Rambla Del Mar, Moll de Espanha e Moll de la Fusta.

\footnotetext{
${ }^{31}$ Em 2001 passaram pelo no terminal WTC cerca de 650.000 passageiros. Fonte: World Trade Center, 2002.

32 O Porto Urbano de Barcelona recebe atualmente por volta de 18 milhões de visitantes por ano. Fonte: Porto de Barcelona, 2002.
} 
Com a ampliação do porto em mais de $2 \mathrm{~km}$ no sentido sul, a abertura da segunda entrada ao porto, já prevista em diversos planos deste 1932 com o Plan Del Gatapc e no Plano de Costas em 1986, conforme informaçôes comentadas anteriormente, passou a ser fundamental principalmente para a renovação das águas interiores (melhora nas questões ambientais), além de permitir o acesso direto ao mar aberto, reduzindo o tempo de percurso em torno de uma hora.

A proposta da segunda entrada ainda considerou a ampliação das áreas públicas com novos espaços ganhos ao mar (15 hectares) para serem utilizados em um empreendimento (Figura 50 e Figura 51) desenvolvido sob responsabilidade do arquiteto Ricardo Bofill. A ampliação e os novos projetos tiveram como objetivo aumentar o potencial da cidade de Barcelona no intercâmbio comercial e turístico com o Mediterrâneo e consolidar definitivamente a aproximação da cidade com sua frente marítima.

A construção de uma nova abertura ao mar separou claramente o Porto de Barcelona em duas unidades, sendo a primeira o porto comercial e logístico e a segunda o porto cívico (Figura 52).

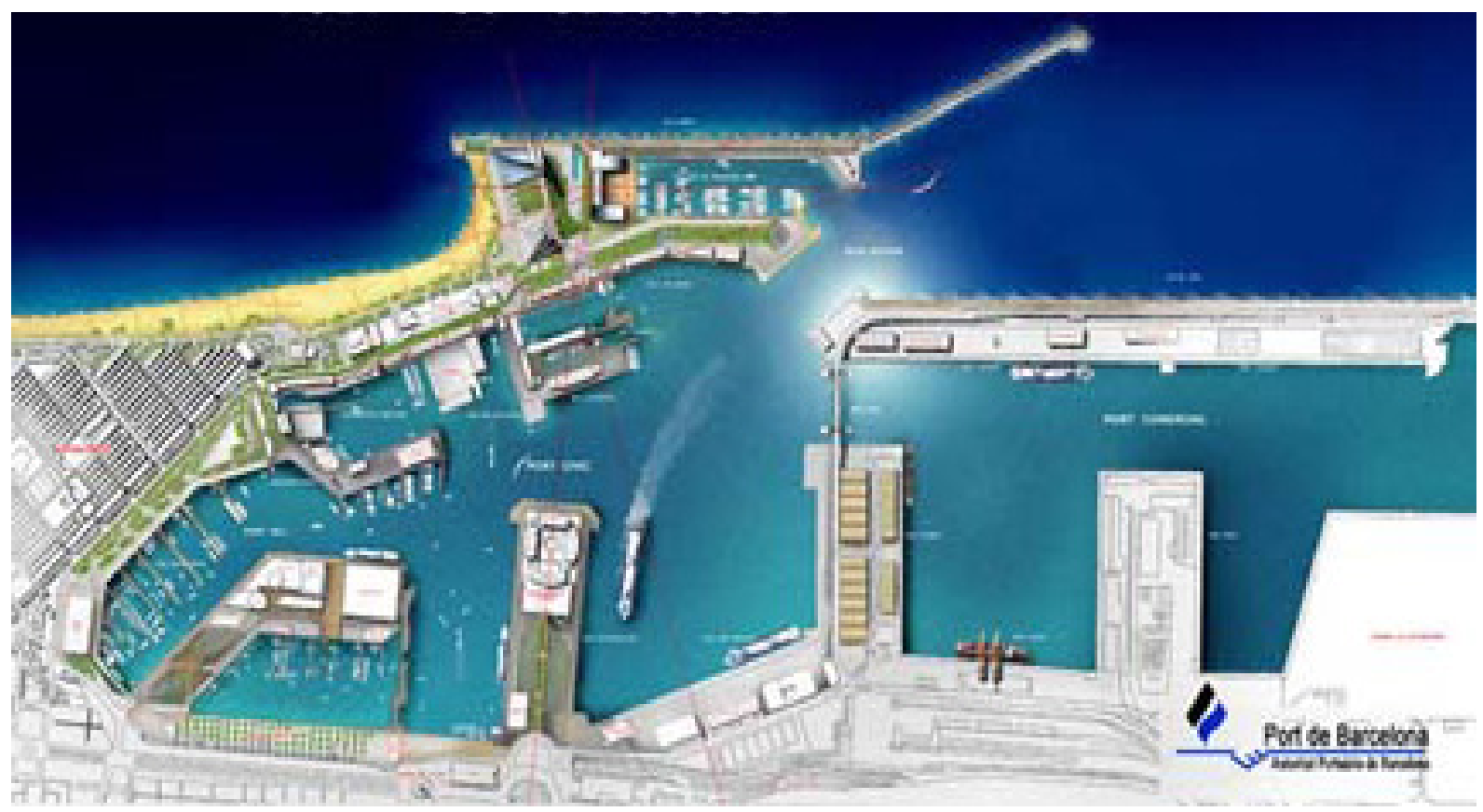

Fonte: http://www.bofill.com.

Figura 50 - Novo acesso do Porto de Barcelona

O sistema de circulação também foi alterado na região do Porto, onde o trânsito comercial, com os navios cargueiros e caminhōes de mercadoria, estão separados dos navios de cruzeiros, barcos pesqueiro e embarcações de recreio. Os pedestres também têm um novo percurso, seguro e rápido, desde o centro histórico até os espaços públicos e equipamentos instalados à beira d'água.

A ampliação do Porto Central de Barcelona representa os esforços em compatibilizar o seu funcionamento com o da cidade e ainda melhorar a qualidade ambiental. 


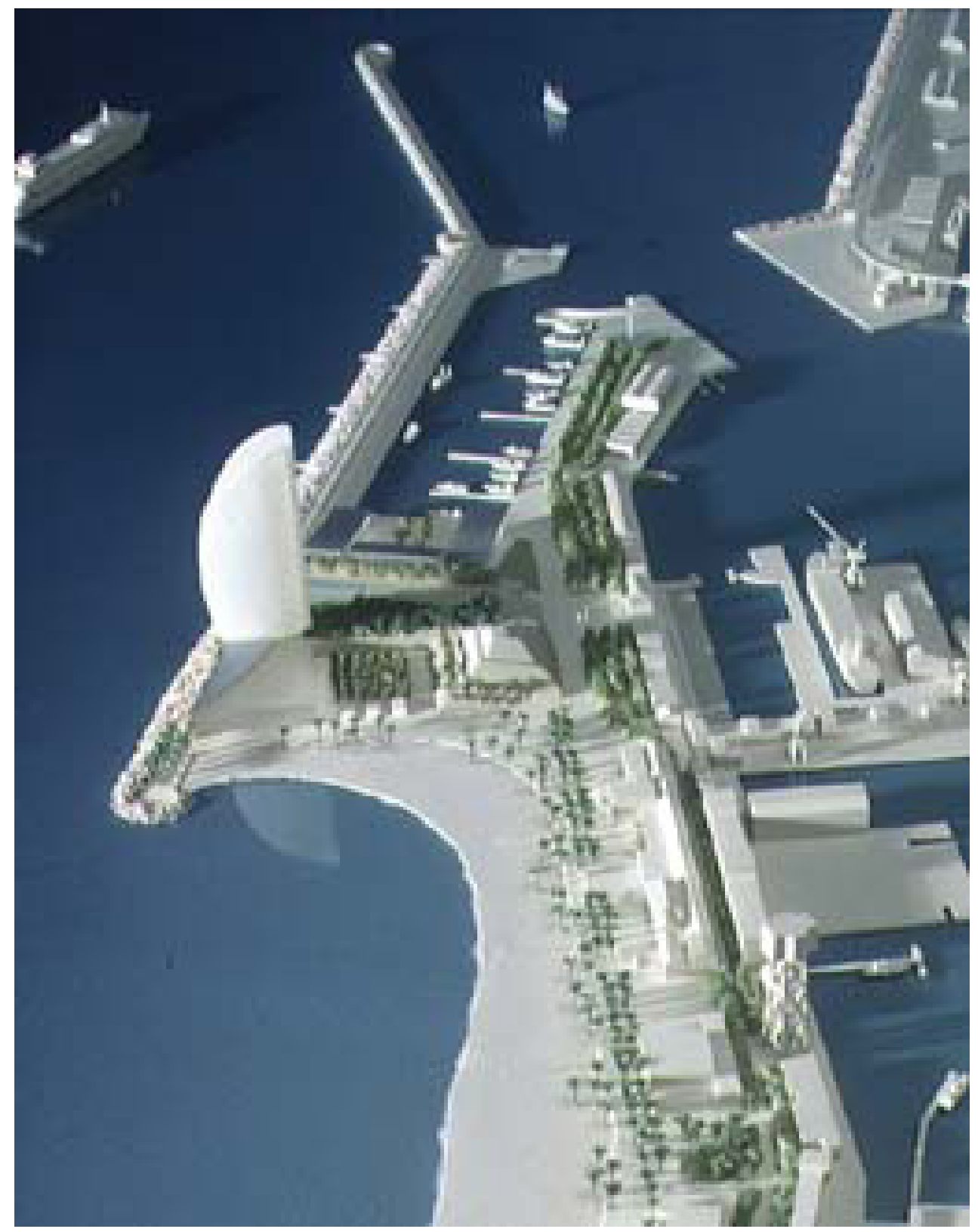

Fonte: http://www.bofill.com.

Figura 51 - Hotel e nova marina

Para o porto comercial, maior eficiência e agilidade nas necessidades do transporte comercial, distribuição e logística.

Para o centro da cidade de Barcelona, a possibilidade de anexar áreas costeiras ao tecido urbano e a consolidação do porto cívico, caracterizado pelas funçôes públicas e recreativas em torno de um espaço centralizador, a grande praça d'água. 


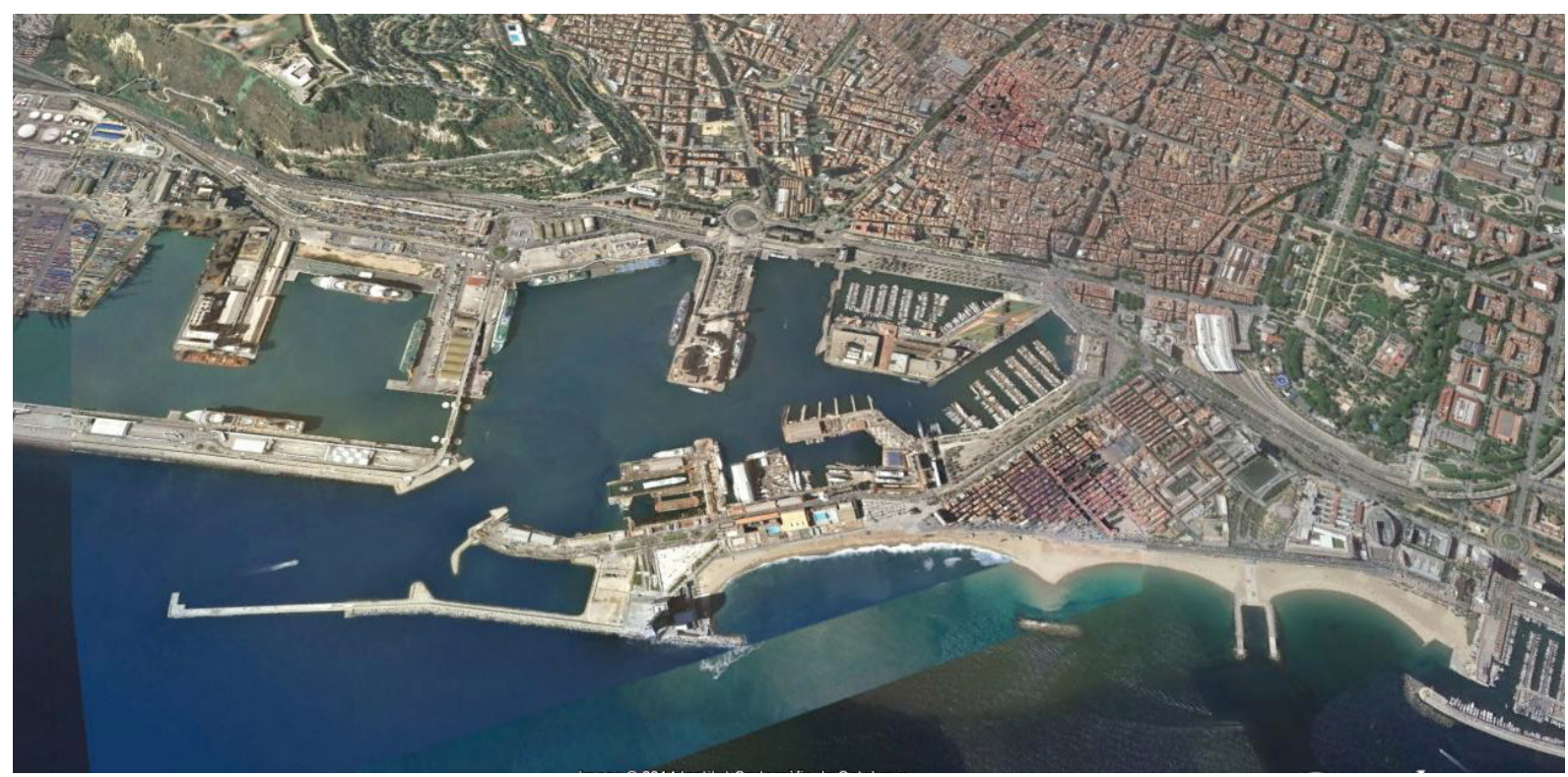

Fonte: Google Earth (2014).

Figura 52 - Novo acesso do Porto de Barcelona

\subsubsection{Portos desportivos}

$\mathrm{O}$ Plano de Costas demonstra que dentro da área de estudo as diversas obras marítimas construídas ao longo dos anos mudaram a morfologia fisiográfica da costa de Barcelona. Isso por falta de estudos mais amplos que levassem em consideração as interferências provocadas por estas obras nas correntes marítimas e das consequências de uma intervenção sobre as outras.

Houve o comprometimento dos fluxos de areia transportada pelas correntes marítimas, fazendo com que até praias desaparecessem, conforme comentários anteriores.

O Plano alertava que estruturas náuticas, como marinas, construções de portos comerciais, proteções de praias entre outros projetos na costa, necessitavam de estudos aprofundados, principalmente dos fenômenos naturais e da morfologia fisiográfica da região, pois qualquer obra construída dentro d'água poderia modificar e influenciar o funcionamento de todo o sistema ambiental da costa metropolitana de Barcelona.

Levantamentos e estudos feitos na década de 1980 demonstraram que apesar do rápido crescimento dos números de embarcações de recreio por habitantes, entre os anos de 1970-1979, a Espanha ainda se mantinha distante em comparação a outros países, conforme demonstrado na Tabela 2.

A Tabela 3 apresenta o número de embarcações por habitante no Brasil em 2012, o que demostra o quanto estamos distantes dos outros países e o grande potencial ainda a ser desenvolvido neste setor. 


\begin{tabular}{|lc|}
\hline País & $\mathbf{N}^{\circ}$ de embarcaçóes por $\mathbf{1 0 0 0}$ habitantes: \\
\hline Noruega & 162 \\
\hline Suécia & 101 \\
\hline EUA & 54 \\
\hline Dinamarca & 35 \\
\hline Gran Bretanha & 15 \\
\hline França & 10 \\
\hline Alemanha & 8 \\
\hline Itália & 6 \\
\hline Catalunya & 4 \\
\hline Espanha & 2 \\
\hline
\end{tabular}

Fonte: Estudo - Plano de Portos Desportivos. Plano de Costas (1987).

Tabela 2 - Número de embarcações por habitantes no mundo

País $\quad$ No de embarcações por 1000 habitantes:

Brasil 0,35

Frota brasileira de embarcações de esporte e recreio acima de 16 pés, entre lanchas e veleiros.

Fonte: ACOBAR - Associação de Construtores de Barcos (2012).

Tabela 3 - Número de embarcações por habitantes no Brasil

No mesmo estudo foi estimado que para a Catalunya, no ano de 1990, faltariam 1.467 vagas para embarcações de recreio e no ano de 2000 o número subiria para 3.555 vagas. Com isso, o Plano de Costas sugeriu que ao longo dos $40 \mathrm{Km}$ de costa a localização das futuras marinas deveriam levar em conta as seguintes recomendaçôes:

- Repercussão das obras sobre a dinâmica do litoral, levando em conta a vulnerabilidade da costa metropolitana, já afetada pelas mudanças nos fluxos de areia.

- Facilidade de acesso desde a rede viária básica metropolitana. São equipamentos que superam o âmbito local e adquirem o âmbito urbano, principalmente pelos serviços oferecidos.

- Levar em consideração a proximidade de assentamentos populacionais, tanto costeiros quanto interiores, para potencializar as possibilidades de desenvolvimento destes locais e garantir o próprio sucesso da marina.

- Distribuição equilibrada, levando em conta as características da bacia fisiográfica.

- Minimizar os impactos causados às praias.

- Estabelecer estudo obrigatório de impacto ambiental sobre a repercussão das novas obras náuticas na dinâmica do litoral.

A lei 55/1969, alterada em 1980, regulamentou a construção e gestão dos portos desportivos, classificando-os em portos de inverno, portos de base e portos de escala. As construções e 
gestôes dos portos desportivos, segundo a lei, poderiam ser solicitadas via concessão pelas seguintes entidades: Corporação Metropolitana de Barcelona, Ajuntamento Costeiro, Conselho Superior de Desportes, Clubes Náuticos, pessoas jurídicas e físicas de nacionalidade espanhola e comunidades autônomas. Para suprir as demandas de vagas das embarcaçôes de recreio, o plano definiu quatro possíveis locais aos novos portos desportivos: porto urbano de Barcelona (até 2.000 vagas molhadas), Porto de Montgat (900 vagas molhadas), Porto de Badalona (400 vagas molhadas / 400 secas e 40 pesqueiras) e Porto de Sitges (924 vagas molhadas).

\subsubsection{Marina do porto urbano de Barcelona}

marina pesqueira e desportiva existente dentro do porto comercial de Barcelona foi definida no Pla-
no de Costas como porto desportivo central e com capacidade prevista para até 2.000 embarcaçōes.

O Plano levanta os vários estudos feitos a fim de melhorar as condiçōes da marina e de sua relação com a cidade. A principal proposta era a abertura de um canal para conectar a bacia diretamente ao mar. Isso, além de melhorar as condições ambientais com a renovação das águas internas em menor tempo, economizaria 5.000 metros que separam essa dársena até a saída ao mar aberto.

A ideia, um antigo desejo da população de Barcelona, está presente em vários planos desde 1932 com o Plano Del Gatcpac, onde apareceu pela primeira vez.

Após estudos e levantamentos, o Plano de Costas formulou a sua proposta para o porto desportivo central, com as seguintes sugestôes:

- Processo progressivo de transformação do uso das dársenas ao uso desportivo.

- Comunicação das dársenas interiores com a nova abertura ao mar para melhorar a renovação das águas interiores e facilitar os acessos (figura 53 e figura 54).

- Continuar utilizando a estação marítima para cruzeiros turísticos.

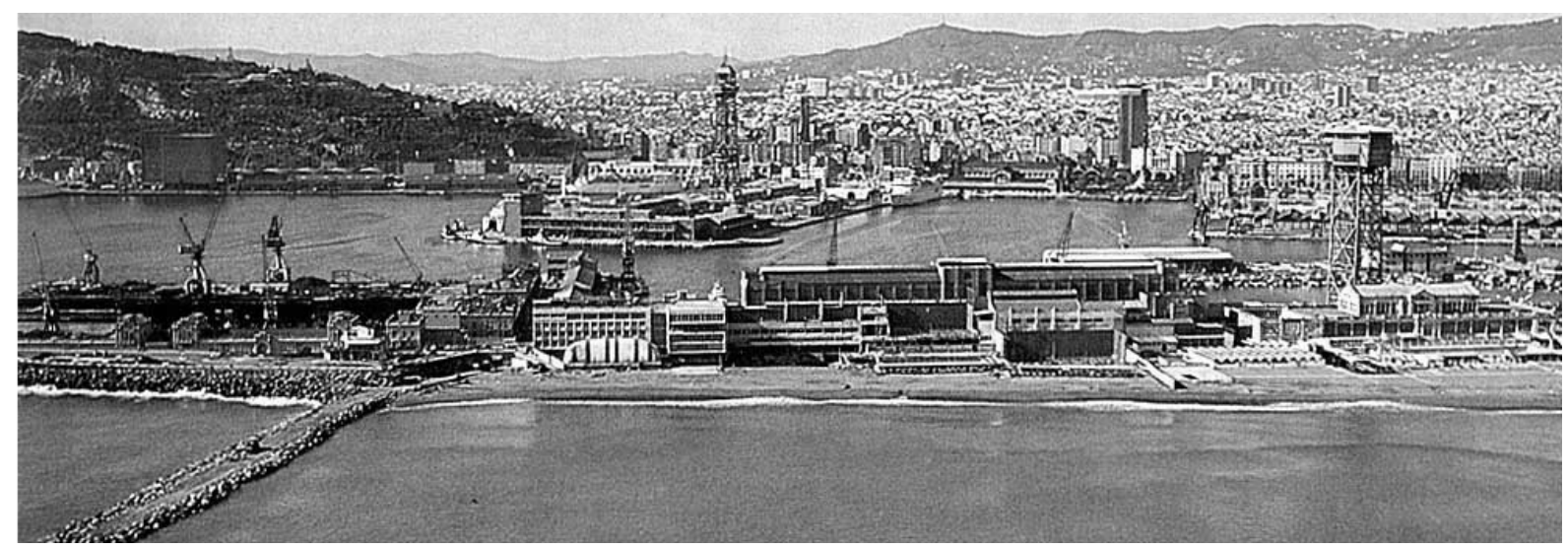

Fonte: Plano de Costas (1986).

Figura 53 - Porto de Barcelona: local da nova entrada para o Porto Transformação do mullle de Barcelona, na porta marítima da cidade. 


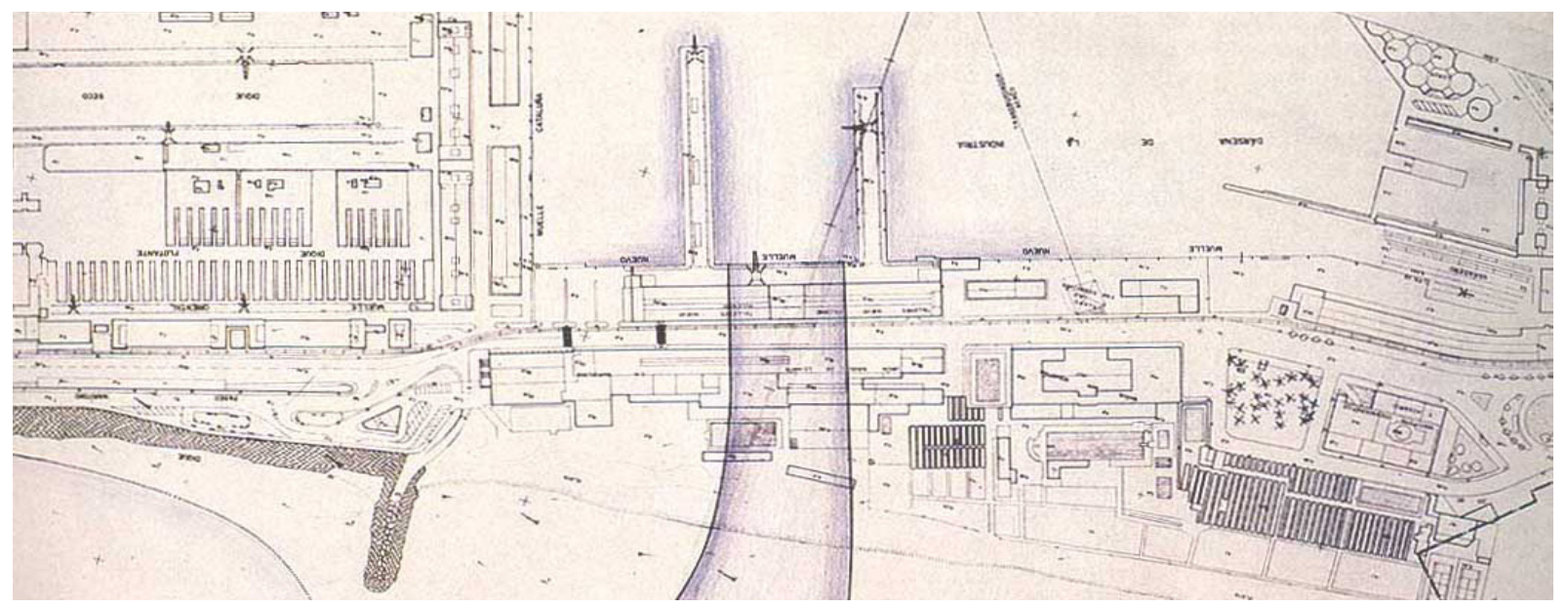

Fonte: Plano de Costas (1986).

Figura 54 - Porto de Barcelona. Propostas de abertura para o porto (segunda entrada)

Na Figura 55 podemos observar a nova frente marítima da cidade de Barcelona, com as obras da reformulação do porto concluídas, a recuperação da praia de Barceloneta e a construção do porto olímpico.

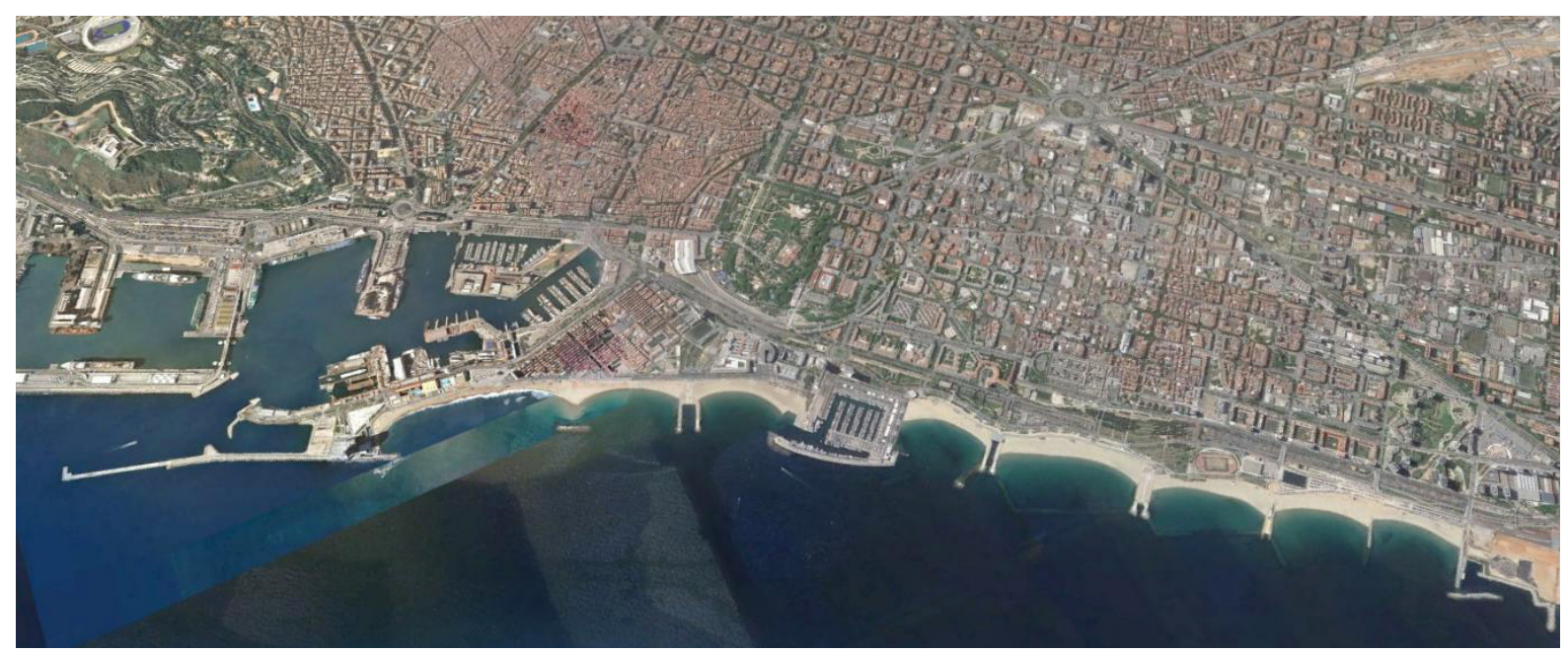

Fonte: Google Earth (2014).

Figura 55 - Nova frente marítima da cidade de Barcelona.

\subsubsection{Porto olímpico}

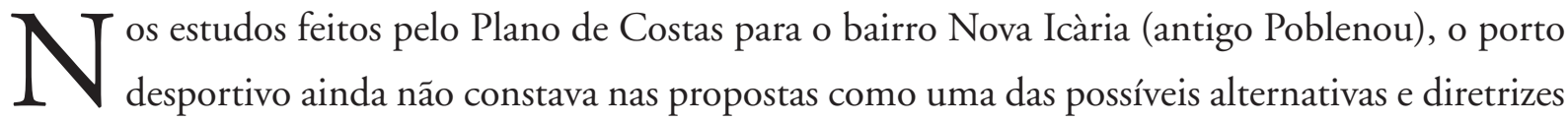
para este setor da cidade. 
Era sugerido apenas o prolongamento da avenida Paseo Carlos I, ${ }^{33}$ com a consolidação monumental e cívica deste eixo, terminando em um palácio de convenções e uma praça aberta ao mar (Figura 56).

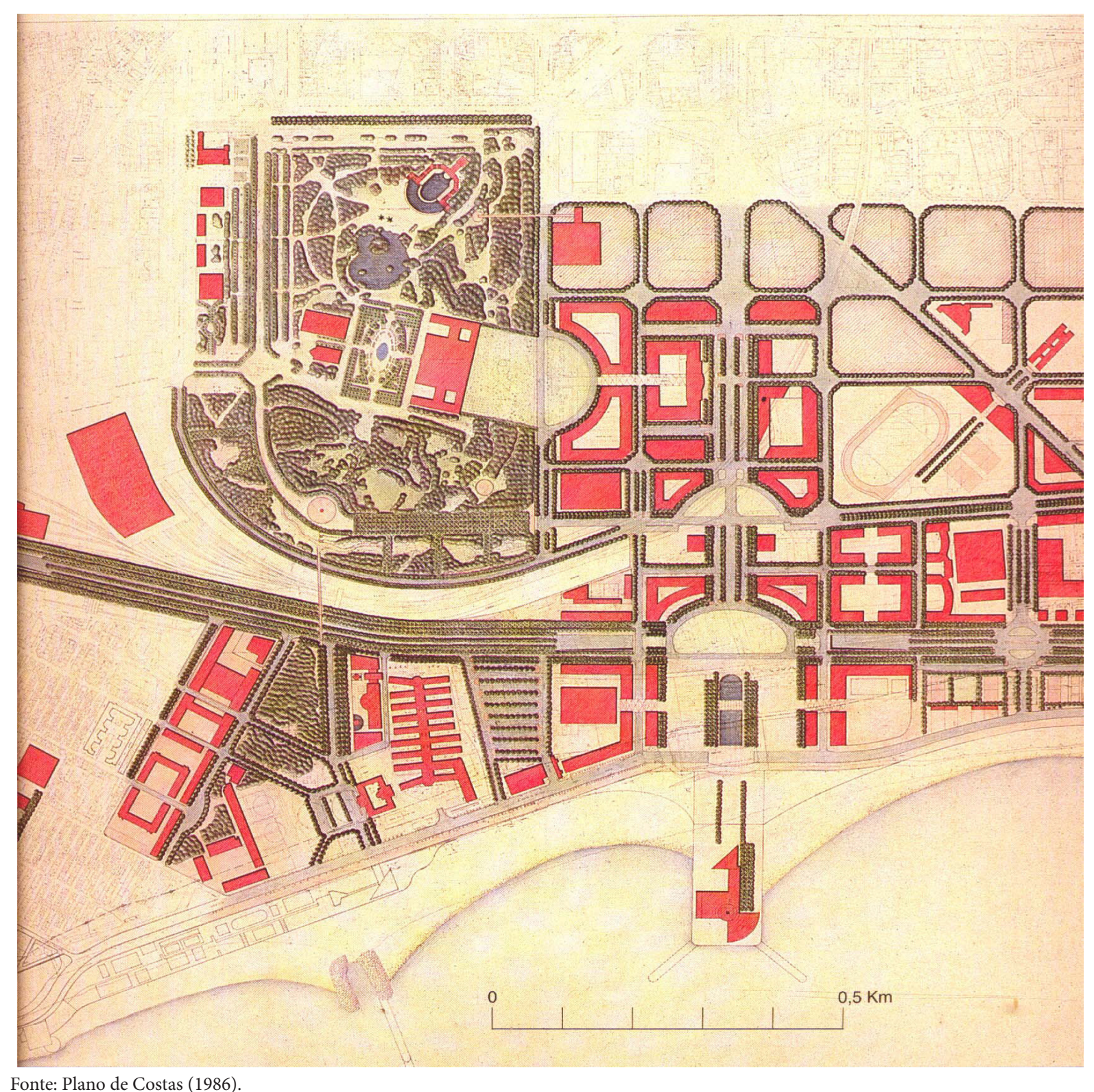

Figura 56 - Projeto inicial para o bairro Nova Icària com prolongamento da av. Paseo Carlos I, terminando em uma praça marítima

A escolha do bairro de Nova Icària para a construção da Vila Olímpica de 1992 e a necessidade de uma base náutica como sede das competiçôes de vela fizeram com que as propostas iniciais, que

\footnotetext{
${ }^{33}$ No eixo Carlos I estariam estruturados e apoiados a remodelação de aproximadamente 78 hectares de terrenos destinados à construção da Vila Olímpica. Eram ocupados anteriormente pela Rede Nacional de Ferrocarriles (RENFE) e por grandes indústrias. A maioria já estava desativada.
} 
consideravam apenas uma praça d'água e local de contemplação, evoluíssem para uma estrutura de apoio à navegação, o que acabou por viabilizar a construção do porto olímpico. Inicialmente, atenderia às questôes olímpicas (competiçôes à vela) e depois passaria a funcionar como importante infraestrutura urbana, fundamental no sucesso do novo bairro. Os Jogos Olímpicos serviram como acelerador das operações urbanas necessárias e fundamentais na remodelação da cidade, ${ }^{34}$ principalmente do setor litorâneo.

As propostas para o bairro Nova Icària tiveram como diretrizes de projeto a continuidade do tecido urbano existente em Barcelona e a manutenção da morfologia já adotada (Plano Cerdà), mas com possibilidades de variações tipológicas.

A coerência e unidade formal foram conseguidas através de normas pré-definidas graficamente que determinavam critérios para as arquiteturas, como o desenvolvimento de anteprojeto indicativos (volumetria e caráter arquitetônico) e obrigatoriedade na utilização do tijolo (de qualquer cor), manter fachadas contínuas e alinhadas às ruas (edifícios com no máximo sete pavimentos), além de articular o conjunto aos espaços verdes.

Neste momento, surge a alternativa de uma pequena dársena circular, criada principalmente para conectar a praia Del Somorrostro à praia de Nova Icària. A proposta também contemplava a possibili-

\footnotetext{
${ }^{34}$ Em 1981, o Ayuntamiento de Barcelona resolve postular a possibilidade de sediar os Jogos Olímpicos de 1992. Para isso, separou o andamento dos trabalhos pré-olímpicos em duas estruturas específicas. Uma delas teria como função trabalhar e trazer as Olimpíadas para Barcelona e depois organizar os eventos esportivos. A outra seria responsável pela coordenação e construção de todas a infraestrutura necessária aos jogos.

Após a confirmação de Barcelona como sede oficial, as coordenações das obras ficaram a cargo de empresas municipais, criadas especialmente para as Olimpíadas.

Com estrutura de sociedade privada, tinham a capacidade de agilizar os processos de gestão e facilidade em conseguir capital no mercado financeiro.

As novas empresas criadas para gerenciar os eventos olímpicos foram as seguintes:

- $\quad$ AOMSA: 22/03/1985 - Anella Olímpica de Montjuic, responsável pelas obras olímpicas e urbanização de Montjuic (onde está o Estádio Olímpico).

- VOSA: 05/12/1986 - Vila Olímpica S.A., responsável pela remodelação da frente marítima e construção do bairro Nova Icària.

- $\quad$ IMPUSA: 14/12/1987 - Institut Municipal de Promocion Urbanística S.A., que em 1989 transformou-se em empresa privada, responsável pelas reformas urbanas em diversos setores da cidade de Barcelona.

- $\quad$ HOLSA: 22/05/1989 - Barcelona Holding Olímpico S.A., empresa criada para assegurar os investimentos públicos, tanto do Estado quanto do Município, na continuidade das obras de infraestrutura e equipamentos olímpicos.

HOLSA era uma instituição pública dona das ações da AOMSA, VOSA e IMPUSA, capaz de canalizar recursos econômicos e financeiros do Estado e da cidade de Barcelona (51\% das ações do Estado e 49\% do Ayuntamiento de Barcelona).

Para gestão do bairro Nova Icària, a Empresa Privada Municipal Vila Olímpica, S.A. (VOSA) atuou no encaminhamento e desenvolvimento dos projetos e viabilizou financiamentos para obras de infraestrutura através de parcerias entre os setores públicos e setores privados.

A empresa, entre 1987 e 1988, comprou todos os terrenos necessários às reformas urbanas, baseados nos valores reais dos imóveis, e evitou a especulação imobiliária. Esta operação deu à administração pública o controle no desenvolvimento dos projetos e na direção urbana previamente estabelecida.

A VOSA foi responsável também pelo processo de desapropriação, demolição, implantação dos projetos urbanísticos, eliminação das vias férreas, construção do novo sistema de coleta de águas pluviais, recuperação das praias e construção do porto olímpico.
} 
dade de embarque e desembarque marítimo e um pequeno espaço para amarras ocasionais de embarcações, mas ainda não oferecia nenhum tipo de serviço ao setor náutico. Nesta fase, as propostas ainda não contemplavam a possibilidade da dársena funcionar como uma marina (Figura 57).

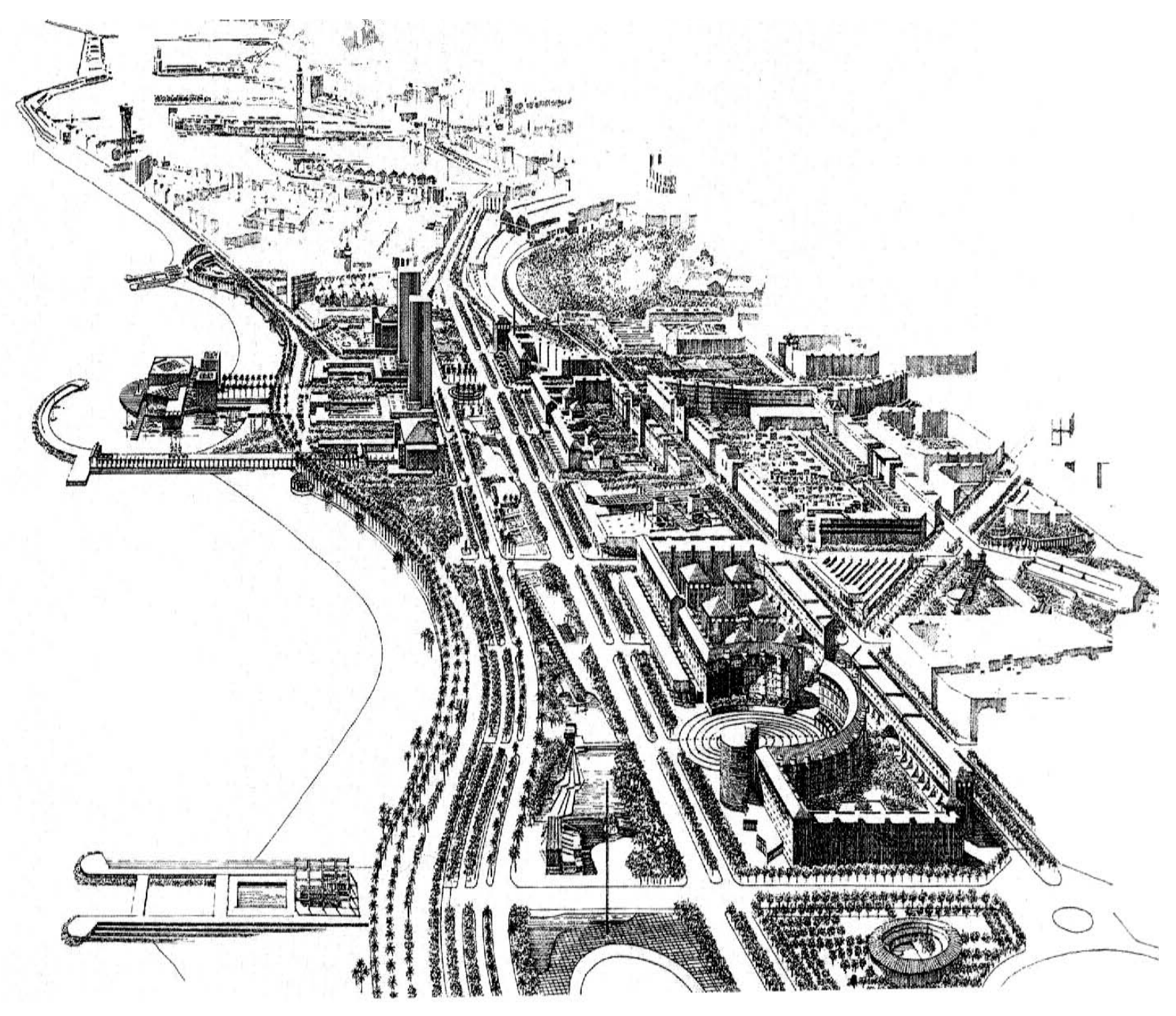

Fonte: A.N.C. (1991).

Figura 57 - Praça d'água antes das adequações olímpicas

A ideia para o local era consolidar a abertura urbana em direção à zona costeira através da construção de uma praça d'água que demonstrasse o caráter público deste novo espaço, permitindo maior proximidade e contato da população com o mar.

Com os Jogos Olímpicos a cidade de Barcelona teria que adaptar um espaço náutico para as provas à vela. A área escolhida foi exatamente a frente marítima do bairro de Nova Icària, endereço da Vila Olímpica, onde seria instalada a base náutica para sediar as competiçôes náuticas.

A decisão provocou a maior modificação nos planos determinados até então para a Vila Olímpica, e o conceito de praça d'água começa a ser modificado. Para atender às exigências das com- 
petições à vela, era necessário ampliar o espelho d'água. Com o desenvolvimento dos projetos e as adequações olímpicas, o espaço ganha características urbanas importantes (Figura 58).

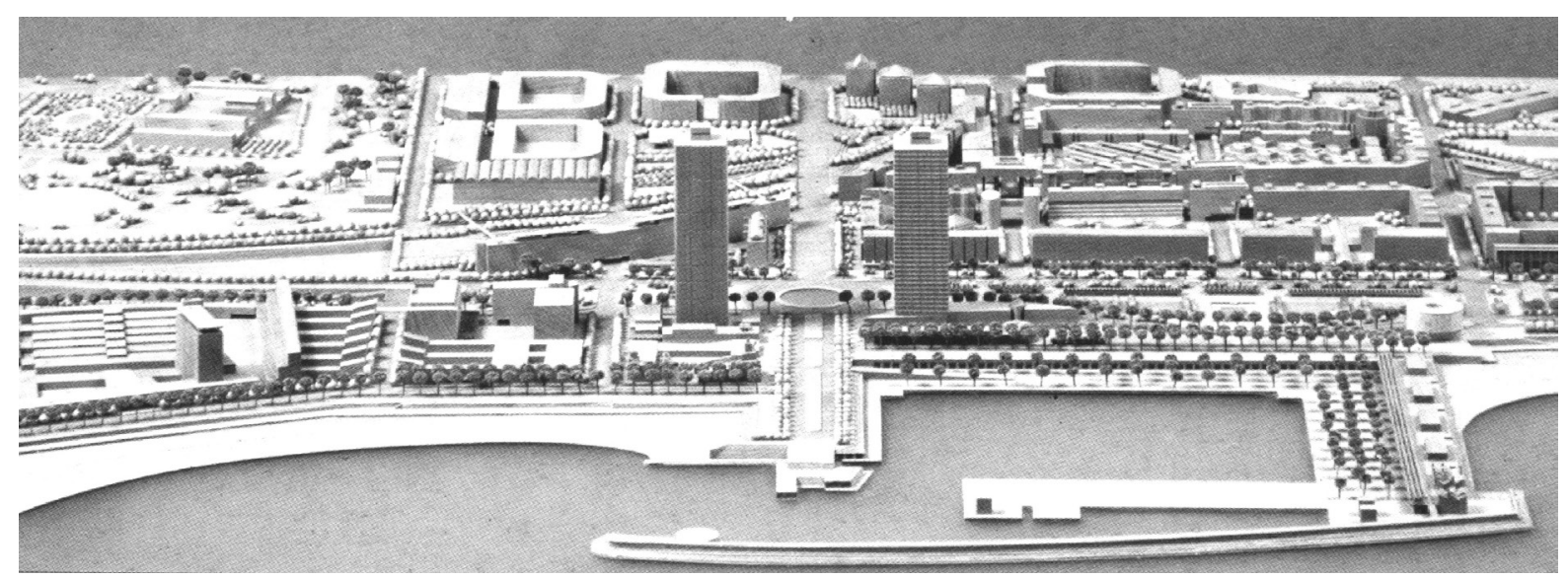

Fonte: BCA (1991).

Figura 58 - Maquete - Porto olímpico e o bairro Nova Icària

A ideia de praça d'água evolui para uma marina de alta exigência funcional (figura 59), com caráter de espaço público e um porto de recreio.

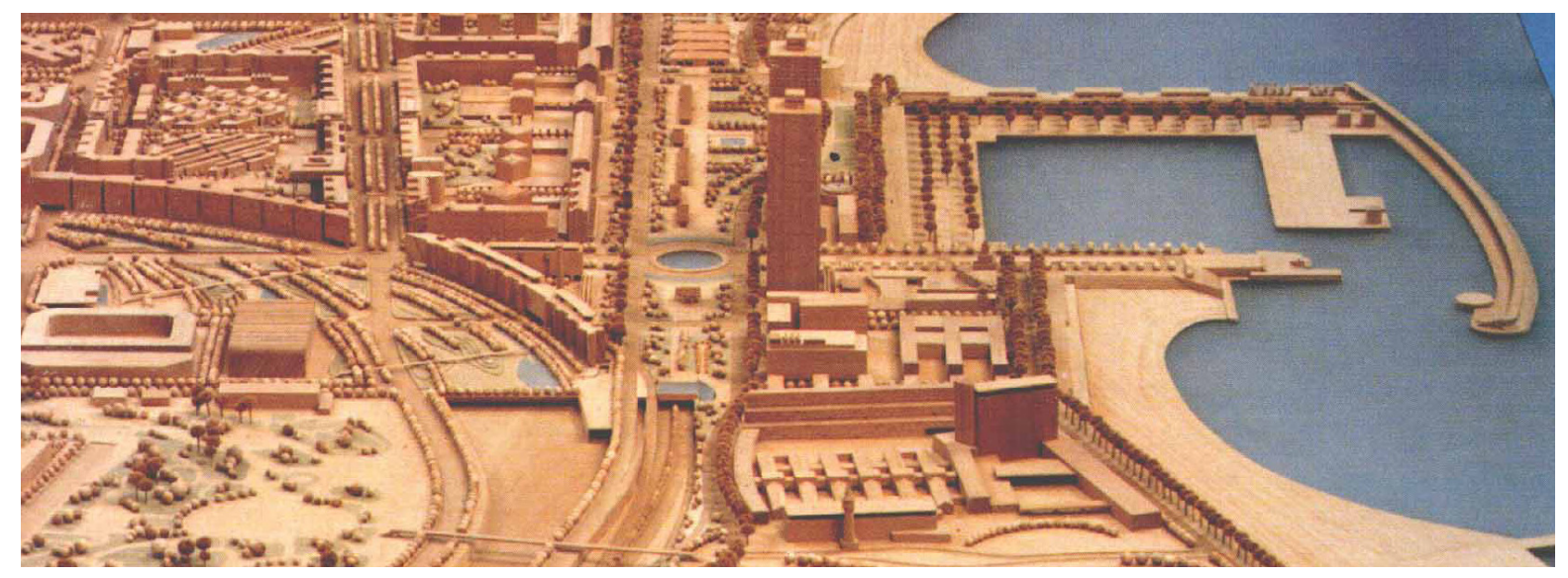

Fonte: BCA (1991).

Figura 59 - Maquete - Porto olímpico já com as adequações

$\mathrm{O}$ porto de recreio gerou uma nova centralidade conectado à malha urbana existente através do parque litorâneo e principalmente pelo prolongamento da avenida Paseo Carlos I, endereço dos dois edifícios que determinam a entrada simbólica do porto.

As soluções adotadas no projeto arquitetônico foram determinantes para possibilitar o acesso da população aos diversos setores do porto, com mais de $75 \%$ de áreas públicas e comerciais, inclusive no dique de proteção principal, chamado de Escullera del Poblenou, que, através das técnicas inovadoras, conseguiramrebaixar as alturas das proteçôes contra a ação do mar , além de ganhar novos espaços públicos e preservar a vista do horizonte desde o passeio marítimo. 
O projeto atendeu aos desejos pré-estabelecidos da conexão cidade-mar com a construção de um ambiente urbano dentro d'água. Após as Olimpíadas, o novo espaço junto ao mar, totalmente integrado à cidade, foi entregue à população como importante área de lazer com uma nova marina, serviços náuticos, estacionamentos e escola de vela municipal (Figura 60).

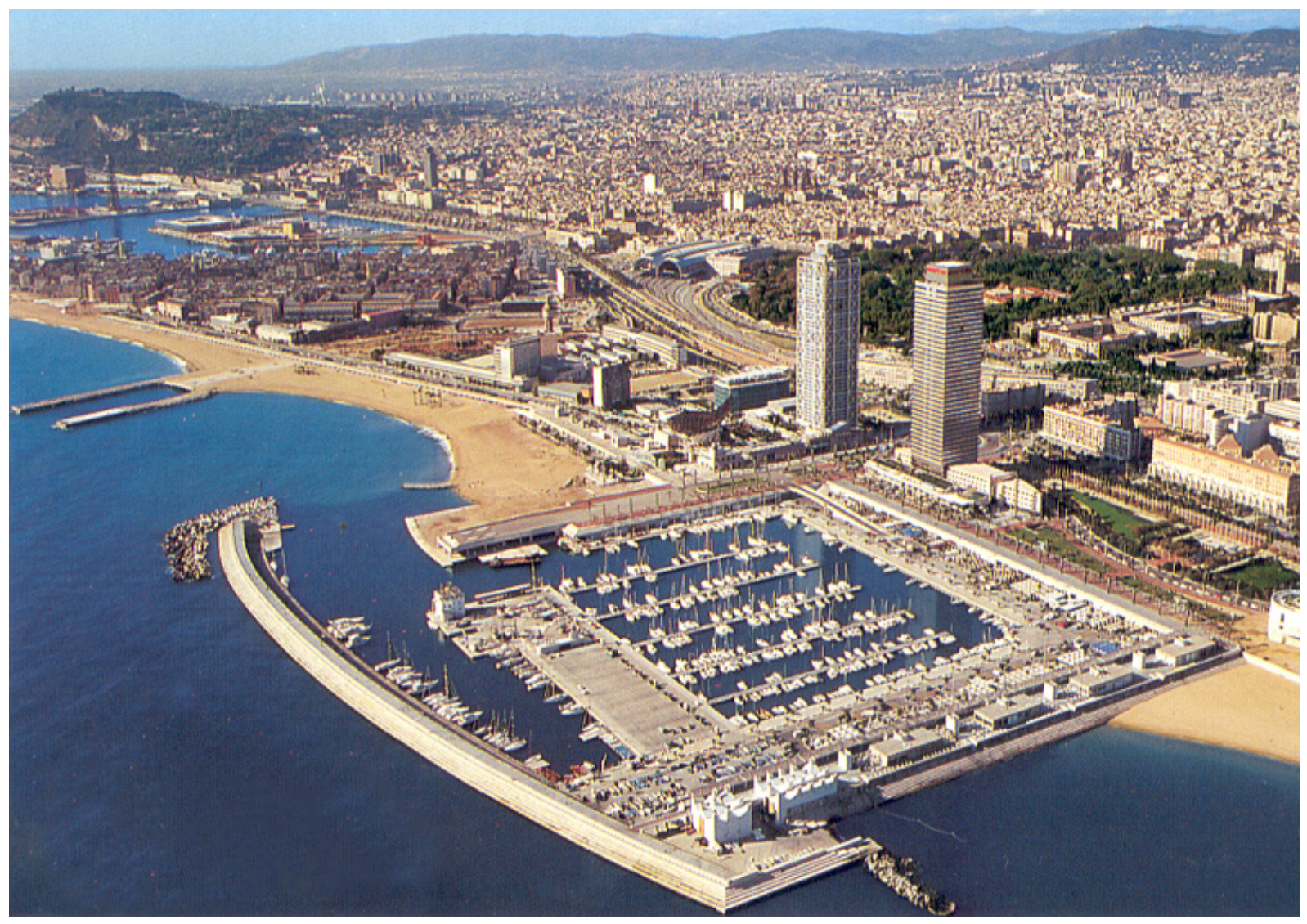

Fonte: Fisa - Escudo de Oro, AS.

Figura 60 - Porto olímpico de Barcelona

A requalificação da área litorânea (Figura 61) próxima ao centro histórico de Barcelona, altamente impactada e decadente, principalmente pelo uso industrial, estava agora apoiada ao novo uso: um porto desportivo, responsável pela estruturação do bairro Nova Icària.

\subsection{Aeroporto}

$\mathrm{O}$ Plano Geral Metropolitano considerava a necessidade de ampliação do aeroporto com a construção da pista sul e ampliação da pista norte. Determinava também que o aeroporto, por estar localizado próximo à costa, deveria ser regulamentado através de regras específicas. 


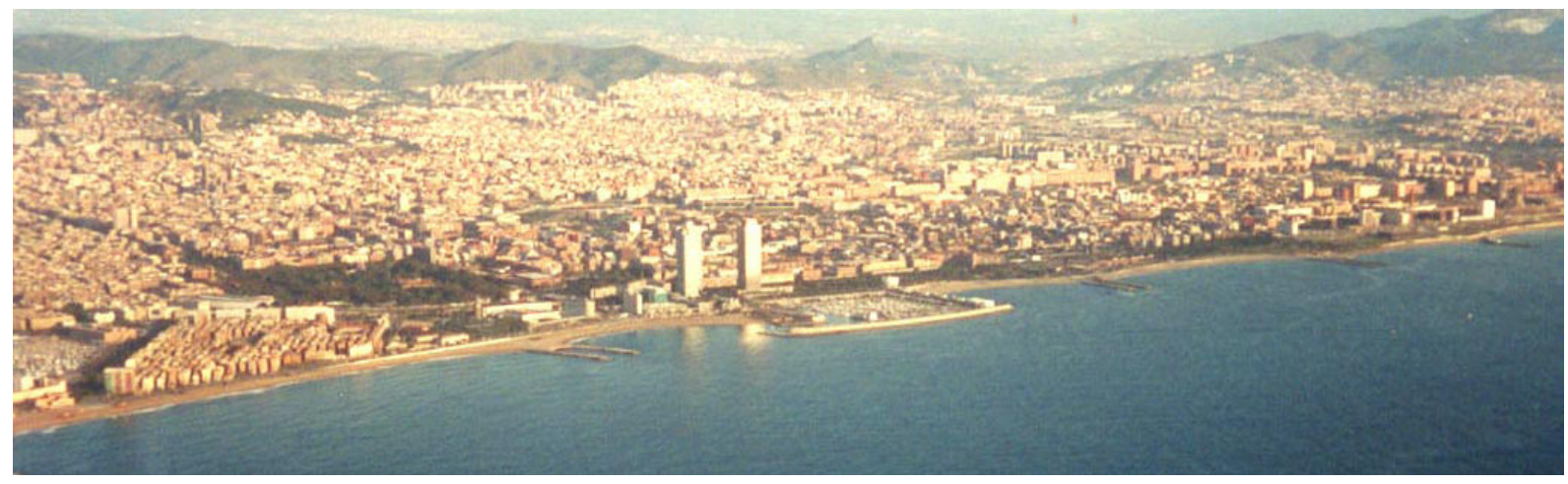

Fonte: José Francisco Xavier Magalhães (2000).

Figura 61 - Frente marítima de Barcelona - porto olímpico

Projetado e construído com a colaboração e participação dos arquitetos Martoreil, Bohigas, Mackay e Puigdormènech, em conjunto com o responsável pelas obras de infraestrutura da Sociedade Privada Municipal da Vila Olímpica S.A. (VOSA), o engenheiro Joan Ramon de Clascà.

A ocupação do seu entorno também estaria sujeita à legislação especial e seriam admitidos pelo Plano Geral Metropolitano de 1976 os seguintes usos nas proximidades do aeroporto: terminais de transportes e todos os usos relacionados às funções aeroportuárias, estações de tratamento de água e esgoto, subestações de energia elétrica, atividades agrícolas, atividades relacionadas à piscicultura, armazéns, centros esportivos, cemitérios, estacionamentos e as reservas florestais com jardins botânicos e parques.

Para as edificações, o PGM permitiria o uso comercial (consumo doméstico e local para exposições), hotéis, motéis, restaurante, bares, armazéns, materiais de construção e usos indústrias, porém sem transformação da matéria-prima.

O Plano de Costas analisou as propostas e fez as suas recomendações, que previam manter as regras de ocupação determinadas pelo PGM, porém com prioridade às funções relativas ao sistema aeroportuário. Propôs modificar o uso do solo em determinadas áreas e classificá-las como reserva natural. A outra proposta era diminuir as áreas de ampliação pretendidas e previstas pelo PGM.

A superfície destinada pelo PGM para o sistema geral aeroportuário era de 1.113 hectares e o Plano de Costas reduziu para 764 hectares.

\subsection{Ferrovias}

$\mathrm{O}$ plano estudou a configuração urbana da zona costeira de Barcelona, fortemente marcada pela presença das instalações ferroviárias (Figura 62), que acabaram definindo o único sentido possível para o desenvolvimento da cidade em direção contrária ao mar e longe da faixa litorânea, com a ocupação das planícies no interior do território. A linha ferroviária ligando Barcelona a Mataró, primeira estrada de ferro da península, construída em 1848, marcou de forma definitiva esta diretriz de ocupação do solo urbano. 

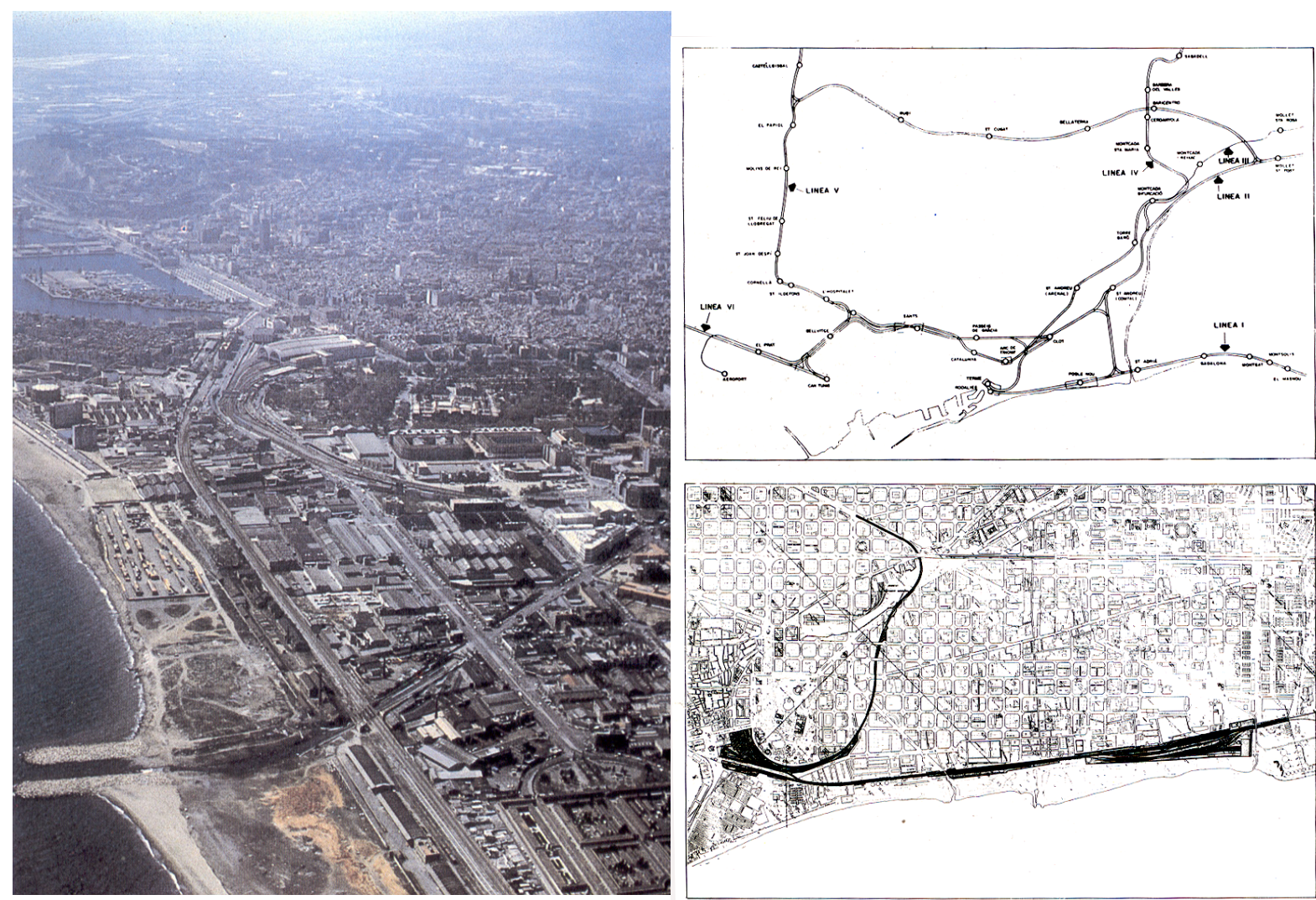

Fonte: Plano de Costas (1986).

Figura 62 - Barreiras ferroviária na área urbana

O desenvolvimento de alguns bairros litorâneos, como Poblenou, Sant Andria, Badalona e Montgat, ficaram condicionados pela passagem da linha do trem. Grandes áreas foram destinadas ao uso industrial, principalmente pelo contato com o transporte ferroviário, iniciando-se assim a separação da cidade em relação ao mar.

Este processo gerou o conceito de que a comunidade urbana metropolitana de Barcelona "vivia de costas para o mar”.

Ao longo dos anos, muitas indústrias fecharam ou mudaram para outros locais e a maioria dos ramais ferroviários ficaram com pouco uso e até obsoletos, iniciando um processo de degradação e abandono do território industrial costeiro.

Em 1983, o Ayuntamiento de Barcelona e a Renfe, Rede Nacional de Ferrocarriles, firmaram um acordo para minimizar os impactos causados pelas linhas ferroviárias ao longo da costa. Algumas das primeiras cláusulas definidas colaboravam positivamente com o Plano de Costas através das seguintes operações conjuntas: as atuais ou futuras conexões com o sistema ferroviário deveriam ser feitas obrigatoriamente em subterrâneo pela estação de Francia e a construção de um novo ramal ligando a estação de Francia com a praça Las Glorias.

Vários estudos e propostas foram realizados pela Direção de Serviços e Transportes da CMB - Generalitat (Corporació Metropolitana de Barcelona), que analisou a problemática gerada pela 
ruptura do tecido urbano causado pela localização do sistema ferroviário e produziu um documento com diversas alternativas. Entre elas, os estudos de viabilidade financeira, impactos e possíveis soluções técnicas, na tentativa de resolver os problemas ocasionados. Uma das possibilidade era a de realocação de diversas estações e linhas ferroviárias costeiras no subsolo, para diminuir as interferências causadas pela passagem dos trens.

Foram levados em consideração os estudos e planos específicos realizados pelos Ayuntamientos de Montag e Badalona, que também propunham suas alternativas para resolver o problema (rebaixamento ou elevação de trechos das linhas ferroviárias na tentativa de minimizar os efeitos negativos por elas causadas).

Em 1985, já levando em conta a realização dos Jogos Olímpicos (1992), a comissão técnica $\mathrm{CMB}$, em conjunto com o Conselho de Administração da Renfe, resolveram colocar em prática o início das propostas de abertura urbana em direção ao mar no trecho compreendido entre o rio Besós e o bairro de Barceloneta (Paseo de Colon - Moll de Fusta).

A partir deste momento, as ampliações das instalações e linhas ferroviárias estariam integradas, de forma definitiva, aos planos de desenvolvimento da cidade de Barcelona, com os seguintes objetivos:

- Abertura urbanística em direção ao mar, recuperando a faixa costeira.

- Integração das instalações ferroviárias com os planos da cidade.

- Aumentar a acessibilidade dos municípios periférico em direção a Barcelona.

- Estação de Francia - manter a estação até se adotar um novo sistema de rede.

- Passar para o subsolo a linha costeira da cidade de Barcelona com a construção de uma estação também subterrânea em frente à rambla do Poblenou.

- Ramal Glorias - proposta de eliminar o ramal para maior permeabilidade urbana neste ponto da cidade.

\subsection{Sistema geral viário}

$\mathrm{O}$ Plano Geral Metropolitano (1976) estudou alternativas para definir quais os traçados mais adequados ao sistema viário geral, influenciando direta e indiretamente a ocupação e desenvolvimento da zona costeira.

O Plano de Costas definiu com mais detalhes alguns elementos considerados importantes para a rede viária, especificamente na faixa costeira, tanto no caráter das vias como em seus traçados, nós e cruzamentos, sugerindo ao PGM outras alternativas. 


\subsection{Sistema geral de serviços técnicos}

$\mathrm{O}$ Plano Geral Metropolitano determinava a ordenação na zona costeira da infraestrutura e dos serviços técnicos, como eletricidade, abastecimento de água, gás, estações de tratamento de esgoto e outros equipamentos. Considerava ainda a necessidade de proteção dos solos e a definição de áreas importantes para preservação ambiental.

O Plano de Costas seguiu os critérios básicos definidos pelo PGM, mas, através de estudos específicos e mais detalhados, sugeriu modificações pontuais para ajustar principalmente a qualificação do solo e de seu uso.

\subsection{Sistema geral de equipamentos comunitários}

$\mathrm{O}$ Plano de Costas não modificou as propostas definidas pelo Plano Geral Metropolitano, que estabeleceu proporções de reservas de solo para os seguintes equipamentos: educação, cultura, saúde e lazer, além das reservas de solo destinado à população de novos assentamentos.

O PGM diferenciou os seguintes tipos de equipamentos: equipamentos públicos e privados existentes, equipamentos novos e de interesse municipal, equipamentos novos de interesse metropolitano (público e privado) e solos qualificados para renovação urbana (serviços técnicos ou de equipamentos).

O estudo não contemplou toda gama de equipamentos coletivos possíveis, mas determinou aos que consumissem maior área a obrigatoriedade de reservas específicas de terrenos, como, por exemplo, os escolares e esportivos.

Os culturais, religiosos, técnicos, administrativos, de segurança e abastecimento deveriam ter escala local.

\subsection{Sistema geral de parques e jardins urbanos}

$\mathrm{O}$ Plano Geral Metropolitano distinguia o sistema de parques e jardins urbanos em três tipos de áreas: parques e jardins urbanos (existentes e de caráter local), parques e jardins urbanos (novos e de caráter local) e parques e jardins urbanos de caráter metropolitano (existentes e novos).

O PGM determinou que os parques urbanos seriam locais destinados a espaços verdes, com grandes superfícies, maiores que $12.000 \mathrm{~m}^{2}$, de domínio e uso público. Foi previsto também que áreas em processo de renovação urbana deveriam gerar novas zonas verdes.

O Plano de Costas aceita as diretrizes determinadas pelo Plano Geral Metropolitano, mas propõe algumas alterações: 
- Ajuste nos perímetros das áreas verdes para os locais afetados por grandes infraestruturas.

- Incorporar as áreas verdes resultantes das operações de remodelação e renovação urbana ao sistema geral de parques e jardins urbanos.

- As áreas recuperadas da ZMT (Zona Marítima Terrestre), em consequência do plano de proteção da faixa litorânea, também deveriam ser incorporadas ao patrimônio municipal e ao sistema geral de parques e jardins urbanos.

As modificações mais significativas propostas pelo Plano de Costas foram feitas principalmente nos limites dos municípios mais afetados pela presença das grandes infraestruturas (Castelldefels, Gavà, Viladecans, El Prat de Llobregat, Barcelona, Sant Adrià de Besòs, Badalona e Montgat).

\subsection{Cronologia - Desenvolvimento do Plano de Costas}

21/04/1983 - Constituição da equipe de trabalho. Comissão permanente da Corporação Metropolitana de Barcelona $(\mathrm{CMB})$ reconhece a equipe de trabalho com funções gerais para elaborar e redigir estudos, planos e projetos da Zona Costeira Metropolitana e coordenar os interesses dos municípios e outros interessados.

05/10/1983 - Início dos trabalhos.

29/04/1984 - Entrega da documentação dos Critérios Objetivos e Soluções Gerais de Planejamento, chamado COSGP.

23/05/1984 - Formada uma Comissão Informativa de Urbanismo.

16/07/1984 - A Comissão Informativa de Urbanismo explica e coloca em debate os Critérios Objetivos e Soluções Gerais de Planejamento em diversas sessóes.

18/07/1984 - Aprovação dos Critérios Objetivos e Soluções Gerais de Planejamento.

A comissão permanente propõe a modificação do Plano Geral Metropolitano e a redação do Plano Especial da Zona Costeira Metropolitana. O conselho metropolitano aprova as propostas da comissão permanente.

28/07/1984 - Entrega e apresentação pública dos informes técnicos e das sugestões do COSGP.

20/12/1984 - Continuidade dos trabalhos. A comissão permanente define o que deve ser desenvolvido nesta nova etapa.

14/01/1985 - Comissão informativa de urbanismo trabalha com as informações técnicas e sugestôes apresentadas.

24/01/1985 - Conclusão das questões analisadas entre o informe técnico e as sugestões públicas apresentadas. A comissão permanente dá o parecer de acordo ao informe técnico e devendo levar em conta os aspectos levantados e presentes na ata da comissão informativa de urbanismo.

04/10/1985 - Entrega da documentação técnica.

24/10/1985 - Aprovação inicial da modificação do Plano Geral da Zona Costeira. 
31/10/1985 - Informação pública da documentação aprovada.

11/12/1985 - Audiência dos municípios e instituições afetadas pelas propostas.

16/06/1986 - Entrega dos informes técnicos e sugestões.

25/06/1986 - A comissão do governo permite que o conselho metropolitano aprove em caráter provisório a modificação do PGM para a zona costeira.

26/06/1986 - Aprovado as modificações do PGM para a zona costeira.

26/06/1986 - Aprovado também o Plano Especial de Ordenação Urbana da Fachada Marítima no setor Paseo de Carlos I - Avenida Icària.

27/12/1986 - A modificação do Plano Geral Metropolitano é objeto de resolução definitiva.

O plano desenvolvido entre os anos de 1983 e 1986, considerou a Zona Costeira Metropolitana de Barcelona como local de especial interesse geográfico e, por isso, deveria ter diretrizes especiais para recuperar as condições exclusivas da faixa territorial voltada ao mar Mediterrâneo.

As propostas permitiram viabilizar as transformaçōes urbanas ocorridas a partir da década de 1980, impulsionadas em grande parte pela realização dos Jogos Olímpicos de 1992

O Plano de Costas compreendeu os problemas causados no território litorâneo em função das diversas ocupações, principalmente a industrial, condicionada pela presença do sistema ferroviário, rodoviário e portuário, implantados próximos e paralelos à zona costeira, forma responsáveis durante anos pela real separação da cidade e de suas frentes marítimas.

A outra questão estudada foram os problemas relacionados às diversas obras dentro d'água, como as proteçõos de praias, portos desportivos e o porto comercial de Barcelona, construídos sem o entendimento conjunto e um planejamento aprofundado sobre as interferências ocasionadas ao meio ambiente, acabando por provocar uma série de mudanças no sistema natural e nas correntes marítimas. Esta realidade alterou significativamente a configuração do litoral metropolitano, onde até praias deixaram de existir.

O desafio enfrentado era estabelecer uma nova diretriz para reverter o processo de degradação da costa e inserir novamente o mar dentro do contexto da cidade, através de novos espaços públicos de lazer. O cuidado foi grande para garantir que as soluções propostas não se transformassem em novas barreiras.

As sugestôes do Plano estavam baseadas no mais amplo conhecimento da zona costeira, das recomendações feitas pelo Plano Geral Metropolitano (1976) e nos diversos estudos realizados, tendo sempre como objetivo principal conciliar a recuperação, o controle ambiental, o desenvolvimento econômico-social e a continuidade da paisagem do litoral para finalmente iniciar o processo de reconstrução de uma nova fachada marítima (Figura 63).

O Plano de Costa elaborado para a recuperação da Zona Costeira Metropolitana de Barcelona, altamente impactada ao longo dos anos, pode ser utilizado como uma importante referência para o Litoral Norte do Estado de São Paulo. 


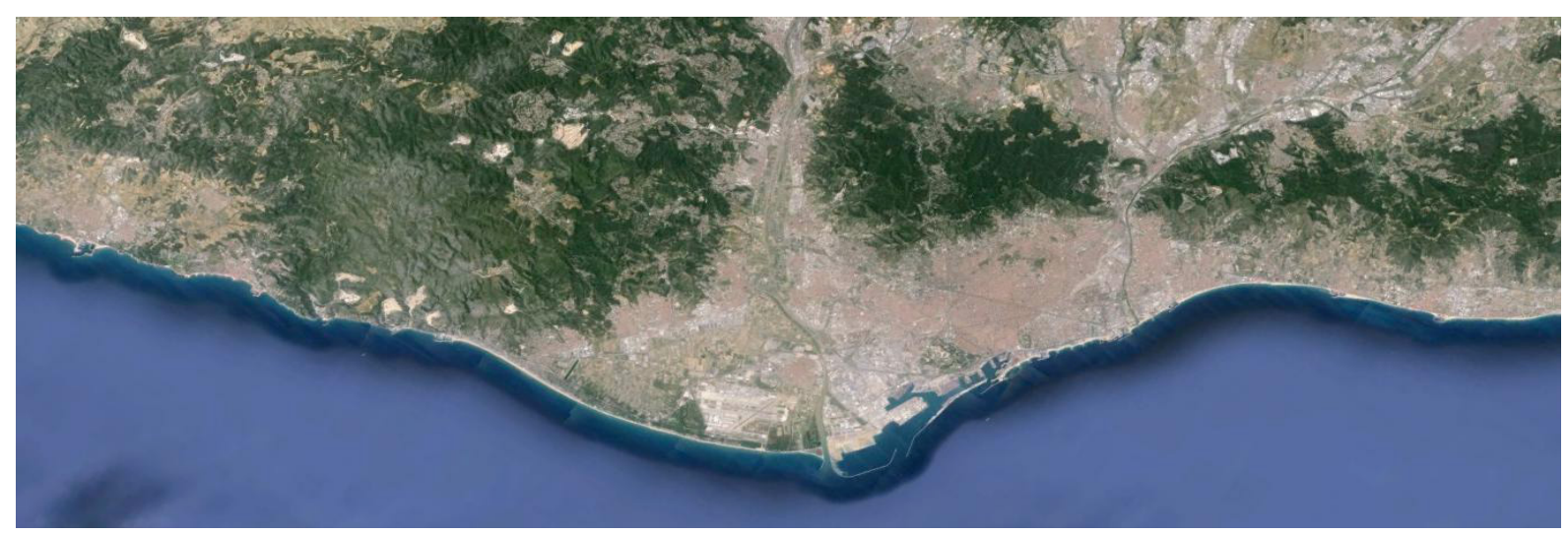

Fonte: Google Earth (2014).

Figura 63 - Vista aérea da cidade de Barcelona desde o município de Sitges até Montgat

A partir da definição de um novo modelo de ocupação territorial, preocupado em resgatar e garantir a maior permeabilidade possível entre mar e superfície terrestre, o Plano demostra a necessidade de um verdadeiro planejamento regional e integrado, mas ao mesmo tempo mantém a preocupação com soluções pontuais, que foram desenhadas para a melhor compreensão projetual dos problemas e possíveis soluções locais.

No caso brasileiro, falta uma consciência maior da importância de seu território litorâneo e da necessidade de planos conjuntos para definir de maneira global os rumos de um crescimento inevitável para a zona costeira que precisa ser disciplinado. 


\section{CAPÍTULO V}

Estudo de Impacto Ambiental - EIA

0 antagonismo da sustentabilidade 
C ada vez mais os planos globais estão sendo substituídos por planos pontuais, o que agrava a compreensão do todo, principalmente em regiões onde o meio ambiente é o maior bem comum. Deveríamos retomar o planejamento regional no Litoral Norte do Estado de São Paulo para maior humanização das cidades, principalmente pelo grande patrimônio natural comum aos diversos municípios que compõe esta região, ou seja, planejar antes o conjunto para que as partes possam se beneficiar de um desenvolvimento econômico equilibrado.

As modelagens matemáticas ${ }^{35}$ poderiam ser ferramentas para auxiliar neste processo, simulando cenários com embasamento científico para entender as novas demandas e quais os caminhos mais sustentáveis. Estes cenários deveriam fazer parte dos estudos ambientais e discutidos de forma mais ampla com representantes da sociedade, ou seja, os termos de referência para elaboração do EIA-RIMA já deveriam contemplar as modelagens matemáticas, com informações reais da capacidade de suporte do território a partir dos usos propostos e das novas demandas.

Com estudos científicos e diagnósticos mais precisos, somados a simulações dos possíveis cenários e seus desdobramentos, as informações facilitariam o entendimento e participação pública nas decisões. O tempo também seria utilizado de forma mais racional, evitando refazer estudos ou inserir novas informações e análises durante o processo.

Seria possível, então, tomar decisões muito mais técnicas e chegar até mesmo à possibilidade de negar determinados empreendimentos, seja de caráter privado ou público, ou conseguir maior força política para buscar recursos e investimentos necessários para alcançar os objetivos previamente definidos e viabilizar tais empreendimentos dentro de uma visão mais sustentável.

O conceito de mitigações e compensações sugeridos pelos estudos ambientais para minimizar os impactos negativos também necessitariam de maiores discussões.

Entender o real impacto negativo ao longo do tempo e seus desdobramentos pode ser um caminho para exigir maiores investimentos do empreendedor e do setor público e garantir muito mais do que o mínimo para compensar o dano causado e respeitar o que é previsto em lei.

Mas se a conclusão de um determinado estudo indica que o dano é irreversível, o caminho é um ressarcimento financeiro para aceitar a destruição ambiental?

\footnotetext{
35 Simulador matemático: revela cientificamente os diferentes cenários e possibilita comparações a partir dos dados utilizados. Pode auxiliar inclusive nas correçōes de estudos, principalmente dos Estudos de Impacto Ambientais.
} 
Será que neste caso o EIA-RIMA não deveria sugerir estudo de novas alternativas ou até atestar pela inviabilidade do projeto?

Segundo Herbert Simon no livro As ciências do artificial, existem sistemas, formas ou comportamentos que simplesmente se adaptam ou são adaptados ao ambiente intencionalmente para alcançar determinados objetivos que são denominados fenômenos artificiais.

As ciências do natural, segundo Simon, é a busca do conhecimento físico e biológico dos seres, fenômenos e objetos, suas características, propriedades, como se comportam, interagem e, através de análises científicas, encontrar um padrão.

Atualmente, o mundo está muito mais artificial que natural e está menos preocupado em entender como as coisas são e mais interessado em compreender como as coisas podem ser, ou seja, projeção da ciência do artificial e fabricado pelo homem. O conceito apresenta a ideia de que não procuramos a melhor alternativa para utilização dos recursos, mas uma alternativa que contemple um resultado pré-definido pelo individuo ou especialista.

As técnicas de simulação podem ser utilizadas como fonte de conhecimento das partes, mas a falta de entendimento do funcionamento destas partes em conjunto muitas vezes são convenientes para evitar o entendimento de alguns detalhes.

Tais simulaçôes consideram a escassez nos diversos segmentos como um fato central, portanto é necessário aplicar o conceito de racionalidade. Podemos entender que no planejamento regional a lógica é encontrar a melhor alternativa como objetivo fundamental deste processo e ainda conservar e distribuir os diversos recursos, que já são escassos de forma racional.

No caso do Litoral Norte de São Paulo, o problema não é a ampliação do porto de São Sebastião para contêineres ou os demais empreendimentos em andamento, mas a complexidade ambiental e limitaçôes do território onde pretendem implantá-los sem antes compreender de forma sinergética e cumulativa os diversos sistemas e subsistemas que compõe a região.

A ciência do natural precisa buscar um ponto de equilíbrio com a ciência do artificial para compreender com mais precisão os sistemas e construir em conjunto seus processos hierárquicos e completos no Litoral Norte de São Paulo.

No livro The regional city, Peter Calthorpe e William Fulton apresentam o projeto regional como uma atividade que integra diversas disciplinas, como a ecologia da região, economia, história, política, legislação, cultura e estrutura social, mas que acabam sempre entendidos como formas físicas independentes. Perde-se a possibilidade de desenvolver uma abordagem de "sistemas inteiros". Cada assunto é tratado de forma isolada, onde especialistas otimizam zonas particulares, sem interesse com o todo e até mesmo de forma intencional para não apontar muitas vezes as mudanças necessárias.

Segundo os autores, a lista de interesses especiais que acreditam nos benefícios do espraiamento é praticamente interminável, mas a cidade regional tem mais a ver com reparação e revitalização 
dos ambientes urbanos e suburbanos existentes do que com a criação de novos lugares, onde o planejamento sempre foi uma forma de equilibrar os direitos individuais com as necessidades da comunidade.

Os autores refletem que para um planejamento regional o desenho deve ser utilizado como síntese das diversas disciplinas e que não podemos aceitar a evolução da cidade apenas como produto da força do mercado e que sua conservação implique apenas em cuidados com os recursos existentes, seja natural, histórico (patrimônio cultural e arquitetônico) social ou institucional.

Os projetos devem também exigir menos recursos (energia, terra, desperdício e materiais) e ainda desenvolver uma ética de reutilização e reparação aplicada ao ambiente construído, bem como para o ambiente natural e não levando em conta só o que é construído, mas também os recursos humanos e da história humana.

Dessa forma, as comunidades devem se esforçar para conservar sua identidade cultural, a história física e seus sistemas naturais, que são únicos.

Peter Calthorpe compara o desenvolvimento e projeto de um bairro com sua região, onde os dois podem e devem ser projetados da mesma forma e precisam ser pensados como sistemas completos. Os resultados serão bairros e regiões mais sustentáveis, integrados e coerentes, principalmente se o bem comum for estabelecer uma identidade ecológica como base do caráter desta região. Para evitar a gentrificação, em um desenvolvimento bem sucedido, são necessárias estratégias regionais que combatam a expansão e a desigualdade, além de esforços para reduzir a destruição ambiental.

\subsection{Compromissos com os recursos naturais e a sustentabilidade}

$\mathrm{P}$ odemos considerar que a preocupação com a preservação dos recursos naturais é um assunto recente na história da humanidade. A partir do século XIX, com a revolução industrial, ficou mais evidente a necessidade de compreender os impactos do desenvolvimento econômico no meio ambiente, mas só em 1968, em uma reunião denominada Clube de Roma, ${ }^{36}$ a possibilidade de colapso ambiental na escala global foi considerada como real caso nada fosse feito imediatamente.

\footnotetext{
${ }^{36}$ Organização não governamental fundada em 1968 formada por representantes de diversos setores da sociedade e de dez países diferentes com o objetivo de discutir o uso indiscriminado dos recursos naturais no mundo. A primeira reunião aconteceu em Roma, o que explica o nome Clube de Roma. Em 1972, o clube solicitou um estudo ao Massachusetts Institute of Technology (MIT) sobre o meio ambiente e propostas para um desenvolvimento sustentável na escala global. Este estudo, denominado Os limites do crescimento, simulou em computador através de um software deMmdelagem matemática - Programa World o uso indiscriminado dos recursos naturais e a tendência de colapso caso nada fosse feito imediatamente. $\mathrm{O}$ estudo utilizou como parâmetro interaçôes entre populaçôes, o crescimento industrial, a produção de alimentos e os limites dos ecossistemas da Terra. Chegou à conclusão de que em 100 anos atingiríamos o limite do crescimento. Este trabalho, entre outras publicações relacionadas ao assunto, foram publicadas, o que influenciou diversos países a aprofundar suas preocupações ambientais e iniciar processos mais efetivos de fiscalização e preservação do meio ambiente através de órgãos fiscalizadores e ministérios específicos.
} 
Nos EUA inicia-se também uma discussão mais ampla, o que acaba por resultar, nos anos 1970, na lei National Environmental Policy Act - NEPA, o primeiro regulamento legal que passa a exigir a empreendimentos com potencial de comprometer negativamente os recursos naturais a necessidade de avaliação destes impactos no meio ambiente. Nascia então o AIA (Avaliação de Impacto Ambiental), instrumento que rapidamente foi adotado também por outros países, como Canadá, Holanda, Grã-Bretanha e Alemanha.

Com o objetivo de buscar compromissos globais ainda maiores com o meio ambiente e políticas públicas de desenvolvimento relacionadas diretamente com os recursos naturais e o bem estar humano e a sustentabilidade, diversas conferências foram organizadas pelo mundo:

- Conferência das Nações Unidas para o Meio Ambiente, Estocolmo, 1972 (declaração sobre o meio ambiente definindo princípios e responsabilidade em relação às questões ambientais e os reflexos do desenvolvimento econômico).

- Convenção de Viena, 1985 (proteção da camada de ozônio).

- Protocolo de Kyoto, Japão, 1997 (metas obrigatórias na redução de 5\% das emissões de gases de efeito estufa para os países industrializados).

- Conferência das Nações Unidas para o Meio Ambiente Eco-92 e Agenda 21, Rio de Janeiro, 1992 (diretrizes para um desenvolvimento mais sustentável com ênfase nos impactos relacionados ao clima, ao desmatamento, à produção de lixo e falta d’água).

- Conferência Ambiental Rio + 10, Joanesburgo, 2002 (declaração de Joanesburgo confirma os compromissos estabelecidos na ECO 92).

- Acordo de Copenhagen, 2009 (limitar o aumento das temperaturas globais até 2020. Os países desenvolvidos devem cortar 20\% de suas emissóes de $\mathrm{CO}^{2}$ até 2020 e $80 \%$ até 2050).

- Declaração de Nova York sobre Florestas, 2014 (reduzir pela metade o desmatamento florestal até o ano de 2020 e zerar em 2030). Documento não assinado pelo Brasil, que alegou não ter sido consultado, o que foi desmentido pelo conselho do Programa de Desenvolvimento das Nações Unidas (PNUD), rebatendo que o país foi convidado mas não se manifestou.

As conferências são importantes e fundamentais para avançar nos acordos ambientais na escala global, mas também fica claro que a maior parte das metas estabelecidas em sua grande maioria não são cumpridas ou não são aceitas, tanto pelos países em desenvolvimento quanto pelos países considerados desenvolvidos, enquanto busca da sustentabilidade.

José Eli da Veiga apresenta os conceitos de sustentabilidade, que tem suas raízes nas reflexões de duas disciplinas consideradas científicas, a ecologia e a economia. Na ecologia, destaca o conceito de resiliência,ou seja, a capacidade de um sistema enfrentar distúrbios e ainda manter suas funçôes e estrutura, além da habilidade de absorver choques, se adequar e tirar benefícios, por adaptação e reorganização. 
Um ecossistema se sustenta se continuar resiliente, por maior que seja o aumento do consumo de energia e a poluição produzida, portanto um outro entendimento de qual o verdadeiro ponto de equilíbrio.

$\mathrm{Na}$ economia, apresenta o conceito de sustentabilidade em três diferentes vertentes. As duas primeiras com ênfase nos estoques: a sustentabilidade "fraca", onde cada geração legue à seguinte o capital propriamente dito, o capital natural/ecológico e o capital humano/social; e a sustentabilidade "forte", destacando a obrigatoriedade de que pelo menos os serviços do "capital natural" sejam mantidos constantes.

A terceira vertente rejeita a ênfase nos estoques e tem foco nos fluxos e busca de indicadores de sustentabilidade.

\section{(...) só pode haver sustentabilidade com minimização dos fluxos de energia e matéria que atravessam esse subsistema, e a decorrente necessidade de desvincular avanços sociais qualitativos de infindáveis aumentos quantitati- vos da produção e do consumo. (VEIGA, J. E., 2009, p.41)}

Segundo Veiga, o conceito de sustentabilidade baseada nos fluxos necessita de indicadores ${ }^{37}$ mais precisos para mensurar aonde está a verdadeira sustentabilidade de uma determinada atividade responsável por impacto negativo no meio ambiente, como indicadores de "bem-estar econômico sustentável” ou "indicador de progresso genuíno".

Também considera um outro grande desafio, a precificação dos danos ambientais negativos, e afirma que sempre será um exercício incerto em definir valores financeiros aos prejuízos diversos.

\footnotetext{
${ }^{37}$ Veiga considera que as mensagens e recomendações que estão no Report by the commission on the measurement of economic performance and social progress (Stiglitz-Sen-Fitoussi, 2009) podem ser considerados como o ponto de partida para a busca destes indicadores. O relatório indicava que os cálculos deveriam ser separados por desempenho econômico, qualidade de vida e sustentabilidade do desenvolvimento:

Mensagens:

- Medir sustentabilidade difere da prática estatística standard - são necessárias projeçõos e não apenas observações. Exige algumas respostas prévias a questôes normativas e cálculos no contexto global.

Recomendações:

- Avaliação da sustentabilidade requer um conjunto bem escolhido de indicadores.

- Possibilidade de interpretá-los como variações de estoques e não de fluxos.

- Índice monetário e econômico de sustentabilidade.

- Aspectos ambientais da sustentabilidade exigem acompanhamento específico por indicadores físicos.

- Medir as várias pressóes humanas sobre os ecossistemas para compará-las à sua capacidade de suporte.

- Contas ambientais acopláveis ao sistema de contabilidade nacional (green accounting).

- Princípio da precaução com bons índices para mensurar.

- Sustentabilidade como necessidade de que o processo socioeconômico conserve sua biocapacidade.

Fonte: VEIGA, J. E. da. Indicadores socioambientais: evolução e perspectivas. Revista de Economia Política, São Paulo, v.29, n.4 (116), p.421-35, out./dez. 2009a
} 


\subsection{Sustentabilidade urbana}

oderíamos considerar um poder público atuante e consciente de sua responsabilidade com o 1 futuro do município, dentro do contexto da região, utilizando e administrando os recursos naturais como um bem público, como uma das premissas importantes na busca de uma sustentabilidade urbana mais eficiente.

Para isto, será fundamental também considerar densidades urbanas mais adequadas, com a opção por ocupaçôes compactas, melhoria constante dos serviços e infraestrutura urbana, como transporte público, tratamento de esgoto, fornecimento de água e energia, menos áreas impermeabilizadas e, consequentemente, maior preservação da paisagem natural.

Abaixo, outras posturas importantes e que auxiliariam na busca de sustentabilidade urbana para as nossas cidades, com destaque para:

- Prioridade para pedestres e ciclistas.

- Bairros com mais espaços públicos de convivência.

- Incentivar a utilização de energias renováveis e menos poluentes, como a eólica e solar

- Considerar a topografia existente e utilizar técnicas construtivas que descartem a necessidade de grandes movimentos de terra.

- Preservação de espécies nativas e valorização dos elementos naturais.

- Monitorar e controlar as emissões dos gases de efeito local e de efeito estufa em razão dos altos índices de emissões de poluição.

- Projetos arquitetônicos e urbanos, mais flexíveis para futuras readequações de uso.

O poder público tem grande responsabilidade na busca da sustentabilidade urbana em seu município e através de legislação específica, de seu código de obras e incentivos fiscais, pode exigir uma nova maneira de construção ou reconstrução das nossas cidades e disciplinar os interesses imobiliários. É necessário garantir um uso do solo diversificado, diminuir deslocamentos da população, levar em conta a acessibilidade universal, incentivar a construção de caminhos exclusivos para pedestres e ciclistas e investir no transporte coletivo de qualidade para desmotivar a utilização do transporte motorizado individual.

A Lei Federal no 12.587 de 2012, instituindo as diretrizes da Política Nacional de Mobilidade Urbana, ${ }^{38}$ é o instrumento da política de desenvolvimento urbano que objetiva a integração entre os diferentes modos de transporte e a melhoria da acessibilidade e mobilidade das pessoas e cargas no território do município. Em seu $\operatorname{art}^{\circ}$ 6, estabelece como diretrizes a integração da mobilidade urbana com a política de desenvolvimento urbano e respectivas políticas setoriais de habitação, saneamento básico, planejamento e gestão do uso do solo. Estabelece também a prioridade dos modos

38 Política Nacional de Mobilidade Urbana. Disponível em: <http://www.planalto.gov.br/ccivil_03/_ato20112014/2012/lei/l12587.htm>. Acesso em: 03/09/2013. 
de transportes não motorizados sobre os motorizados e dos serviços de transporte público coletivo, ${ }^{39}$ considerados estruturadores do território e indutores do desenvolvimento urbano integrado. Apesar do transporte coletivo ser uma prioridade, estabelecida por lei, o que vemos na prática é o incentivo ao transporte individual quando o próprio governo oferece incentivos fiscais (redução de IPI - Imposto sobre produtos Industrializados) para compra do transporte motorizado individual, o que resulta em congestionamentos cada vez maiores, e consequentemente degradação do espaço urbano, com o comprometimento da qualidade de vida dentro dos municípios.

Se pensarmos que um município tem prerrogativa constitucional na gestão de seu território, pensando em São Sebastião, muito poderia ser feito em conjunto com municípios vizinhos na busca de qualidade ambiental e urbana na escala regional, com a identificação de políticas públicas integradas e ações de planejamento utilizando os seus principais instrumentos como Zoneamento Ecológico-Econômico - ZEE, o Plano Diretor Municipal, o Plano de Bacia Hidrográfica, o Estatuto da Metrópole e a recém-criada (2012) Região Metropolitana do Vale do Paraíba e Litoral Norte, composta por 39 municípios e dividida em cinco sub-regióes. ${ }^{40}$

Mas não bastam apenas ações preventivas e normativas dos instrumentos de planejamento se elas não forem colocadas em prática para controlar os impactos territoriais negativos, resultado das explorações dos recursos naturais.

\subsection{PAC e a sustentabilidade urbana}

$\mathrm{O}$ Brasil, desde 2007, através de programas federais - PAC 1 e PAC 2 (Programa de Aceleração do Crescimento) $-^{41}$ incentivam, segundo seus objetivos, o crescimento de forma acelerada e sustentável em grandes obras de infraestruturas social, urbana, logística e energética do país, com aumento da oferta de empregos e geração de renda. ${ }^{42}$

39 O veículo como sistema de transporte individual deveria perder espaço, com novos incentivos ao transporte público, com destaque para o hidroviário no caso do litoral paulista, proporcionando uma nova integração e alteração na ocupação urbana, principalmente na faixa litorânea.

40 A sub-região 5 é o enfoque principal deste trabalho e está relacionada com a zona costeira do Litoral Norte do estado de São Paulo, composta pelos municípios de Caraguatatuba, Ilhabela, São Sebastião e Ubatuba

${ }^{41} \mathrm{O}$ PAC 1 dobrou os investimentos públicos brasileiros (de 1,62\% do PIB em 2006 para 3,27\% em 2010) e gerou um volume recorde de empregos - 8,2 milhões de postos de trabalho criados no período. Para o PAC 2 (a partir de 2011), mais recursos foram reservados para o programa e mais parcerias com estados e municípios foram fechadas para a execução de obras estruturantes. Disponível em: <http://dados.gov.br/dataset/obras-do-pac-programa-de-aceleracaodo-crescimento>. Acesso em: 04/08/2014.

42 Em 2014, o Governo Federal lançou o terceiro plano denominado Programa de Aceleração do Crescimento - PAC 3 , porém, muitas das obras importantes do PAC 1 (2007), que já deveriam estar prontas em 2014, ainda não foram concluídas, como a usina hidrelétrica de Belo Monte, a transposição do rio São Francisco e a refinaria da Petrobras em Pernambuco - Abreu e Lima (suspeita de superfaturamento - previsão dos custos inicial de R \$ 5,6 bilhôes para 
O conceito “aceleração" pretendido pelo PAC é uma contradição ao sustentável. Executar rápido e com pouco planejamento o que deixou de ser feito ao longo do tempo pode influir negativamente na qualidade urbana de nossas cidades.

Apesar da necessidade de investimentos nos mais diversos setores de infraestrutura do Brasil, é necessário tempo para um planejamento responsável e estudos cumulativos dos seus efeitos colaterais.

Os benefícios positivos apontados pelos diversos EIA-RIMA podem ser momentâneos e a pressa poder ser fatal, queimando etapas importantes, como estudos técnicos mais aprofundados e ampla discussão pública, para um desenvolvimento mais consistente, duradouro e que leve em consideração sobretudo a capacidade de suporte deste território.

Atualmente, a agilidade na elaboração dos EIA-RIMA passam a ter grande expectativa de aprovação, tanto do setor privado quanto do poder público, para obtenção o quanto antes das licenças ambientais e início das obras. É o caso da duplicação do trecho Planalto da rodovia dos Tamoios, a construção da nova rodovia denominada Contorno Sul em São Sebastião e Contorno Norte em Caraguatatuba, a ampliação do píer da Petrobras e a ampliação do Porto de São Sebastião. Todos estes projetos passam por processo de licenciamento, aprovação e construção na região, sem estudos sinergéticos e cumulativos mais aprofundados, o que aumenta e muito o risco de insustentabilidade ambiental e urbana na região, principalmente em São Sebastião.

Considerando que todos os empreendimentos sejam construídos, cada um com suas justificativas e conclusões de serem os responsáveis pelo desenvolvimento econômicos e sociais, e que São Sebastiāo e região serão beneficiados, podemos afirmar com este trabalho que falta planejamento e projetos urbanos. A não avaliação dos EIA-RIMA em conjunto e de forma sinergética resultara em empreendimentos fragmentados e desarticulados do território e suas especificidades.

A cidade precisa ser projetada e desenhada com antecedência para indicar e exigir, principalmente ao mercado imobiliário e aos grandes empreendimentos, como eles devem e podem estar articulados ao tecido urbano e aos interesses coletivos.

R\$ 26,8 bilhôes). Dos 101 projetos considerados mais importantes, como duplicação de rodovias, refinarias, portos e aeroportos, 70 projetos ficaram prontos depois do prazo estimado, em média 4 anos de atraso, além dos custos estimados que também aumentaram; 27 não foram concluídos e 4 foram abandonados. Disponível em: <http://www1. folha.uol.com.br/poder/2014/08/1495021-dilma-relanca-pac-com-30-das-grandes-obras-inacabadas.shtml>. Acesso em: 04/08/2014. 
CAPÍTULO VI

Arcabouço legal

Legislação ambiental e o Estudo de Impacto Ambiental - EIA 
$\mathrm{O}$ presente capítulo apresenta uma análise acerca das leis brasileiras que norteiam o tema "meio ambiente", com destaque para o período pós-promulgação da Política Nacional de Meio Ambiente, em 1981, e as diretrizes e normativas que orientam o licenciamento dos empreendimentos de significativo impacto a partir dos Estudos de Impacto Ambiental - EIA.

A Figura 64 organiza, no período de 1934 a 1988, o arcabouço jurídico brasileiro, estabelecido no âmbito dos governos da federação brasileira.

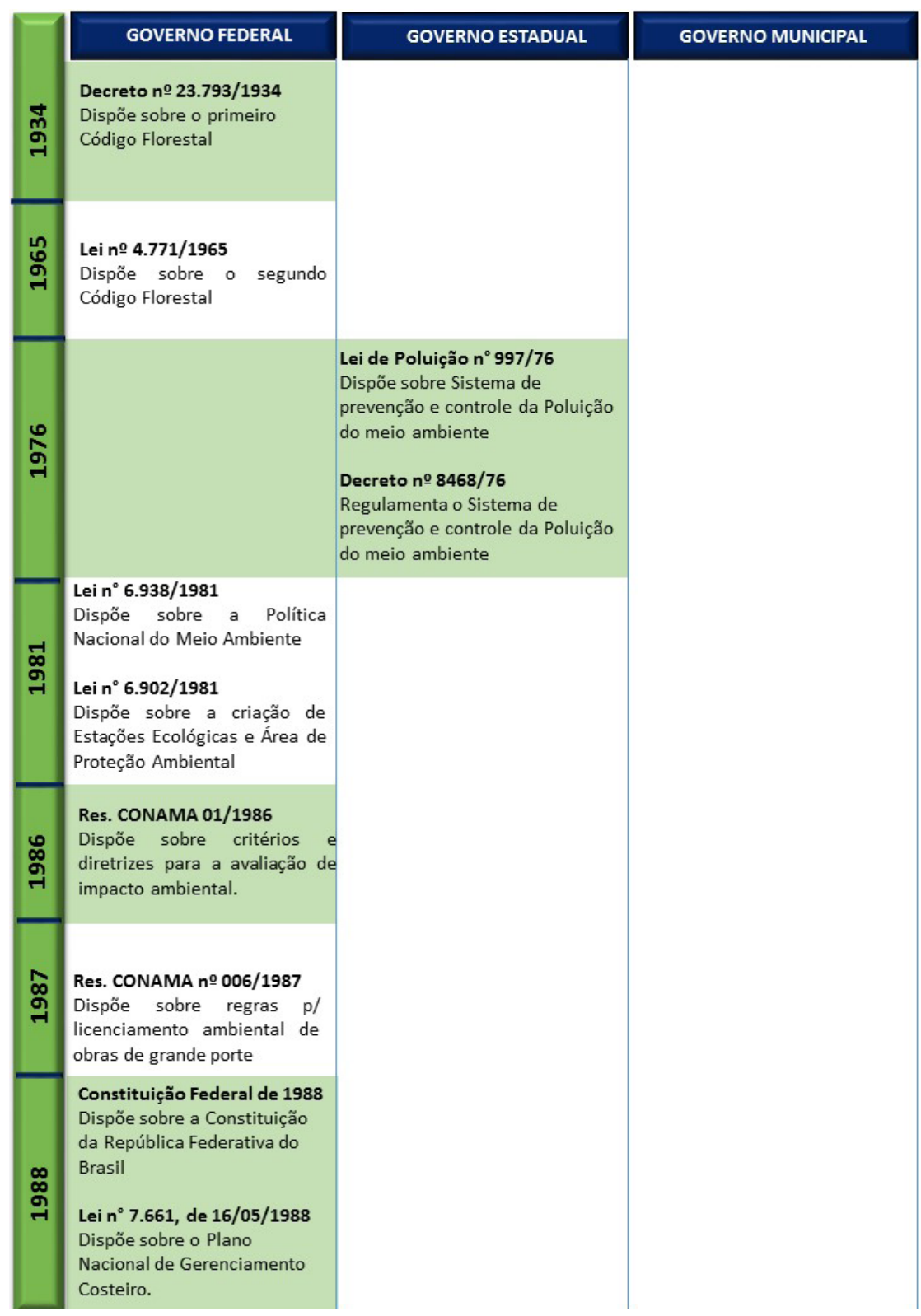

Figura 64 - Linha do tempo da legislação ambiental brasileira - período 1934 a 1988 
$1930-1965$

No Brasil, a partir dos anos 1930, em meio ao governo Vargas, um dos primeiros marcos legais relacionados ao meio ambiente foi a promulgação do Decreto 23.793/1934, com intuito de estabelecer normas que regulassem e minimizassem os efeitos negativos do desenvolvimento econômico em razão da exploração da madeira.

Após 30 anos da promulgação do primeiro Código Florestal, diante da necessidade de garantir maior proteção dos recursos naturais, tendo em vista o cenário posto e em razão do avanço indiscriminado sobre as florestas (supressão de vegetação para garantir o avanço da produção), o segundo Código Florestal foi sancionado, por meio da publicação da Lei Federal no 4.771/65 que, embora tenha sofrido algumas modificações, manteve suas premissas e objetivos. Essa lei se preocupou com a preservação dos recursos hídricos e as áreas de risco (encostas íngremes e dunas), denominando-as assim de Áreas de Preservação Permanente (APP).

Conforme já discutido no Capítulo 5 do presente trabalho, a Conferência de Estocolmo, na Suécia, em 1972, inaugura a agenda ambiental e o surgimento do direito ambiental internacional. Quatro anos depois, no estado de São Paulo, foram estabelecidas as primeiras regras para a prevenção e controle da poluição do meio ambiente com a Lei Estadual nº 997, de 31 de maio de 1976.

1976

A Lei Estadual n 997 dispõem sobre a prevenção e o controle da poluição do meio ambiente. Considera-se poluição do meio ambiente a presença, o lançamento ou a liberação, nas águas, no ar ou solo, de toda e qualquer forma de matéria ou energia que provoquem inconvenientes ao bem-estar público, danos materiais à fauna e à flora e prejuízos à segurança e às atividades normais da comunidade.

As fontes de poluição ficam sujeitas à prévia autorização do órgão estadual de controle do meio ambiente através das seguintes licenças com prazos de validade determinados:

- LAP - Licença Ambiental Prévia: fase preliminar (devem ser atendidos os requisitos básicos em relação à localização, instalação e operação).

- LAI - Licença Ambiental de Instalação: autoriza o início da implantação de acordo com as especificações constantes nos projetos aprovados.

- LAO - Licença Ambiental de Operação: autoriza o início das atividades licenciadas, desde que com o funcionamento simultâneo dos equipamentos de controle ambiental, previamente exigidos.

A lei define também que só poderão ser concedidos financiamentos com recursos do Governo às empresas que apresentarem o certificado emitido pelos órgãos estaduais de controle da poluição, autorizando as atividades pretendidas.

O Decreto Estadual no 8468/76, que regulamenta a Lei Estadual supracitada, determina a proibição do lançamento ou liberação de poluentes nas águas, ar e solo fora dos padrōes pré-estabelecidos, 
para garantir a qualidade ambiental, o bem-estar público e a proteção da fauna e flora. Além disso, determina que o meio ambiente deve ser monitorado e preservado por meio da elaboração e implantação de planos e programas controladores da poluição, tanto para atividades públicas quanto privadas.

A competência para aplicar o Decreto é da Companhia Estadual de Tecnologia de Saneamento Básico e de Defesa do Meio Ambiente (CETESB), que fornecia as Licenças de Registro para a instalação e funcionamento das atividades pretendidas.

\section{1}

Antes da homologação da Política Nacional de Meio Ambiente, no início da década de 1980 foi sancionada a Lei 6.902, de 27 de abril de 1981, que definia os mecanismos jurídicos para a proteção das áreas com atributos ambientais, como é o caso das Estaçôes Ecológicas (EE) e das Áreas de Proteção Ambiental (APA).

Apenas com a promulgação da Lei no 6.938/1981 - Política Nacional do Meio Ambiente (PNMA) e do Sistema Nacional do Meio Ambiente (SISNAMA) é que o assunto relacionado ao meio ambiente começa a ser discutido com mais ênfase, muito mais por pressão Internacional do que por iniciativa própria, o que resultou na consolidação das políticas públicas de meio ambiente que orientou todas as normativas posteriores, incluindo a necessidade de regulamentar o processo de licenciamento ambiental, ou seja, exigência de autorização para atividades ou empreendimentos potencialmente poluidores e de significativo impacto, que se mantém até os dias de hoje.

Para alcançar o seu principal objetivo, a PNMA definiu que era necessário estabelecer o zoneamento ambiental da seguinte forma: (i) áreas prioritárias e representativas de ação e interesse governamental relativa à qualidade e ao equilíbrio ecológico; (ii) o estabelecimento de critérios e padrões da qualidade ambiental e; (iii) de normas do uso e manejo dos recursos naturais, considerado um patrimônio público a ser necessariamente assegurado, protegido e fiscalizado, tendo em vista o uso coletivo.

Além disto, incentiva estudos, pesquisas e o desenvolvimento de tecnologias para o uso racional e proteção dos recursos ambientais, principalmente os locais ameaçados de degradação (solo, subsolo, água e ar), recuperação de áreas degradadas, restaurando seus recursos ambientais, e, ainda, a divulgação pública de dados e informações ambientais, esclarecendo a importância do equilíbrio ecológico.

Para garantir a implementação dos objetivos e diretrizes, a PNMA propôs a criação do Sistema Nacional do Meio Ambiente (SISNAMA), composto por órgãos e entidades da União, Estados, Distrito Federal, Municípios e Fundações, que seriam responsáveis pela proteção e melhoria da qualidade ambiental.

O SISNAMA é composto por um Conselho Nacional do Meio Ambiente (CONAMA) que, segundo o PNMA, é responsável pelo estabelecimento das normas e critérios para os licenciamentos ambientais das atividades potencialmente poluidoras. As licenças são concedidas pelos Estados 
e supervisionadas pelo Instituto Brasileiro do Meio Ambiente e dos Recursos Naturais (IBAMA). Atualmente, o SISNAMA tem a seguinte estrutura:

a) Órgão superior: conselho do Governo. Desempenha funções de assessoramento do Presidente da República na formulação da política nacional e das diretrizes governamentais para o meio ambiente e recursos ambientais. Composto pelos Ministérios da Presidência da República.

b) Órgão consultivo, deliberativo e normativo: CONAMA. Tem a finalidade de assessorar o conselho do Governo na formulação de diretrizes da política nacional ambiental e tem competência para estabelecer resoluções. Suas atribuições estão no art. 8. ${ }^{\circ}$ da Lei 6.938/1981.

c) Órgão central: Ministério do Meio Ambiente, com competência para preservar, conservar e fiscalizar o uso racional dos recursos naturais renováveis, bem como para implementar acordos internacionais na área ambiental, entre outras. O Ministério é composto pelo Conselho Nacional do Meio Ambiente, Conselho Nacional da Amazônia Legal, Conselho Nacional dos Recursos Naturais Renováveis, Comitê do Fundo Nacional do Meio Ambiente, Secretaria de Coordenação dos Assuntos da Amazônia Legal e Secretaria de Coordenação dos Assuntos de Desenvolvimento Integrado. Após nova estruturação, surgiram as seguintes secretarias: Mudanças Climáticas e Qualidade Ambiental, Extrativismo e Desenvolvimento Rural Sustentável, Recursos Hídricos e Ambiente Urbano, Articulação Institucional e Cidadania Ambiental, Biodiversidade e Florestas, e Secretaria Executiva.

d) Órgão executor: constituído pelo IBAMA - Instituto Brasileiro do Meio Ambiente e dos Recursos Naturais Renováveis (criado pela Lei 7.735, de 22 de fevereiro de 1989) e pelo Instituto Chico Mendes (criado pela Lei 11.516, de 28.08.2007). Tem a função de formular, coordenar, executar e fazer a política nacional do meio ambiente e preservação, conservação e uso racional, fiscalização, controle e fomento dos recursos naturais.

e) Órgãos setoriais: são aqueles integrantes da administração pública federal direta ou indireta, incluindo fundações instituídas pelo poder público, com atividades ligadas à preservação ambiental (Ministérios da Agricultura, da Ciência e Tecnologia, da Saúde, da Fazenda etc.). Não estão arrolados no art. 6. ${ }^{\circ}$ da Lei 6.938/1981, pois foram agrupados nos arts. 3. ${ }^{\circ}$, V e 13 do Dec. 99.274/1990, erroneamente denominados órgãos seccionais.

f) Órgãos seccionais: órgãos ou entidades estaduais que atuam na execução de programas ou projetos, bem como a fiscalização e controle de atividades com potencialidade para degradar o meio ambiente. No estado de São Paulo podemos citar a SMA - Secretaria Estadual do Meio Ambiente, o CONSEMA - Conselho Estadual do Meio Ambiente, a CETESB - Companhia Estadual de Tecnologia e de Saneamento Ambiental, além da CFA/SMA - Coordenadoria de Fiscalização Ambiental da Secretaria Estadual de Meio Ambiente e a Polícia Militar Ambiental da Secretaria Estadual de Segurança Pública.

g) Órgãos locais: órgãos ou entidades municipais responsáveis por controlar e fiscalizar tais atividades, em suas respectivas áreas de jurisdição. 


\section{$1986-1987$}

Uma das primeiras normativas deliberada pelo CONAMA foi a Resolução Federal do CONAMA 001/86, por meio da Política Nacional de Meio Ambiente instituída em 1981 pela Lei 6938/81, que estabelecia os procedimentos, critérios e diretrizes gerais para a elaboração dos Estudos de Impacto Ambiental (EIA) e respectivo Relatório de Impacto Ambiental (RIMA).

A Resolução considera impacto ambiental qualquer alteração das propriedades físicas, químicas e biológicas do meio ambiente causada por qualquer forma de energia resultante das atividades humanas que afetam a saúde, a segurança, o bem-estar da população, as relações sociais e econômicas, as condiçōes estéticas e sanitárias do meio ambiente e a qualidade dos recursos ambientais. Para os Estudos de Impacto Ambiental (EIA), as seguintes diretrizes são fundamentais na elaboração dos trabalhos:

- Caracterizar o empreendimento.

- Contemplar alternativas tecnológicas e de localização do projeto.

- Identificar os impactos nas fases de implantação e operação das atividades.

- Definir os limites das áreas a serem direta e indiretamente afetadas.

- Levantar outros projetos e obras em desenvolvimento na área de influência, analisando as possíveis interferências.

- Realizar o EIA através de equipe multidisciplinar habilitada e independente do empreendedor responsável pelo projeto.

- Diagnóstico ambiental completo da área de influência do projeto em relação aos aspectos do meio físico, biológico e socioeconômico.

- Análises dos impactos ambientais tanto positivos quanto negativos antes da execução do empreendimento ou funcionamento da atividade.

- Definição de medidas mitigadoras dos impactos negativos. ${ }^{43}$

- Monitoramento constante dos impactos positivos e negativos.

- Avaliação de alternativas e estratégias - minimizar e compensar efeitos negativos

- Se for o caso, atestando pela inviabilidade do mesmo.

O Relatório de Impacto Ambiental (RIMA) é o resultado dos Estudos de Impacto Ambiental, que deverá ser apresentado de forma objetiva, ${ }^{44}$ demonstrando de forma clara as justificativas, descrição do projeto e suas alternativas tecnológicas.

Deve ser apresentada a síntese dos resultados dos estudos de diagnóstico ambiental, com descrição dos prováveis impactos ambientais na implantação do projeto, caracterização da qualidade am-

\footnotetext{
${ }^{43}$ A resolução CONAMA 02/96 e a Lei do SNUC (Sistema Nacional de Unidade de Conservação) definem os critérios para as medidas compensatórias e reparação dos danos ambientais, caso florestas e outros ecossistemas sejam destruídos. Geralmente, determina-se a implantação de uma unidade de conservação permanente e de domínio público (preferencialmente uma estação ecológica).

${ }^{44}$ Linguagem de fácil compreensão, principalmente para permitir a consulta pública (comunidade local).
} 
biental futura da área de influência e descrição das medidas mitigadoras para os impactos negativos, com acompanhamento e monitoramento dos impactos negativos bem como os positivos.

Os empreendimentos e atividades para os quais se exige EIA-RIMA são projetos urbanísticos acima de 100 ha, parcelamento do solo, complexos turísticos e de lazer, obras civis, de utilidade, estaçôes de tratamento, viadutos ou obras em áreas consideradas de relevante interesse ambiental, a critério da Secretaria do Meio Ambiente (SMA) e dos órgãos municipais e estaduais competentes,

O Artigo $7^{\circ}$ estabelece que o EIA-RIMA deve ser realizado por equipe multidisciplinar habilita$\mathrm{da}$, não dependente direta ou indiretamente do proponente do projeto.

O Artigo $8^{\circ}$ estabelece que todas as despesas, custos e soluções técnicas dos estudos serão de total responsabilidade do proponente.

\section{8}

Outro importante marco na legislação brasileira foi a promulgação da Constituição Federal de 1988, pois dedica um capítulo específico à proteção ambiental, estabelecendo "o direito ao ambiente sadio como um direito fundamental do indivíduo".

O Capítulo VI. Art.225 determina que para a boa qualidade de vida todos têm o direito de usufruírem o meio ambiente ecologicamente equilibrado, hoje e no futuro, onde o poder público e a própria população têm o dever de promover e garantir sua preservação. Determina ainda, em seu artigo $4^{\circ}$, que:

\section{[...] para instalação de obra ou atividade potencialmente causadora de significativa degra- dação do meio ambiente, estudo prévio de impacto ambiental, a que se dará publicidade. (BRASIL, 1988)}

De acordo com Édis Milaré, o reconhecimento do direito a um meio ambiente ecologicamente equilibrado configura-se, "numa extensão do direito à vida, quer sob o enfoque da própria existência física e saúde dos seres humanos, quer quanto ao aspecto da dignidade dessa existência - a qualidade de vida, que faz com que valha a pena viver".

A Constituição Federal estabelece em seu artigo 225 que:

\section{(...) Todos têm direito ao meio ambiente ecologicamente equilibrado, bem de uso comum do povo e essencial à sadia qualidade de vida, impondo-se ao poder público e à coletividade o dever de defendê-lo e preservá-lo para as presentes e futuras geraçôes. (BRASIL,1988)}

O Art. 225 estabelece ainda que a Floresta Amazônica brasileira, a Mata Atlântica, a Serra do Mar, o Pantanal Mato-Grossense e a Zona Costeira são considerados patrimônios nacionais. Só poderão ser utilizados com a garantia de manter a qualidade do meio ambiente e dos recursos naturais, tendo como principais objetivos a preservação e restauração dos processos ecológicos essenciais, preservação da diversidade e integridade do patrimônio genético (fauna e flora), definir espaços territoriais e seus 
componentes a serem protegidos e promover a educação ambiental. Exige também a elaboração de Estudo de Impacto Ambiental para obras ou atividades potencialmente causadoras de significativa degradação do meio ambiente.

É possível depreender também que a Constituição Federal, de maneira indireta, reconheceu vários princípios constitucionais, dos quais destacamos:

\section{- Princípio do desenvolvimento sustentável;}

O princípio do desenvolvimento sustentável deve ser entendido em consonância com os demais princípios de proteção ambiental. $\mathrm{O}$ bem que propicia o desenvolvimento econômico, social, cultural, político é o mesmo que importa para a manutenção da sadia qualidade de vida. Por isso, não tem sentido que o desenvolvimento se dê de forma desordenada e cause dano ao meio ambiente. (IGLECIAS, P. 2013, p. 50) (Grifo nosso)

De acordo com a autora, "entre os instrumentos de aplicação do princípio do desenvolvimento sustentável, ressalta-se a avaliação de impacto ambiental já prevista na Lei 6.938/1981, a Constituição Federal, que prevê o estudo prévio de impacto ambiental e, a Lei 12.305/2010, que cuida da Política Nacional de Resíduos Sólidos”. (Grifo nosso)

É relevante, nesse momento, destacar que o conceito de desenvolvimento sustentável, reconhecido constitucionalmente, norteia uma das principais políticas públicas ambientais do país desde da década de 1980 .

\section{- Princípio do poluidor-pagador:}

Patrícia Iglesias, em seu texto apresentado no curso de capacitação do Programa Serra do Mar, destaca uma referência importante na qual define que "O principio poluidor-pagador é aquele que impóe ao poluidor o dever de arcar com as despesas de prevenção, reparação e repressão da poluição. Ou seja, estabelece que o causador da poluição e da degradação dos recursos naturais deve ser o responsável principal pelas consequências de sua ação (ou omissão)". (Antônio

Herman Benjamin, O princípio poluidor-pagador e a reparação do dano ambiental, p. 226)

O princípio poluidor-pagador consta da Declaração do Rio sobre Meio Ambiente e Desenvolvimento de 1992, princípio 16, na Lei Federal no 6.938/81, Art. 4º que dispõe sobre a Política Nacional do Meio Ambiente, e Lei Federal no 9.433/97, que dispõe sobre a Lei das Águas, além de estar disposto no art.225, \$3º da Constituição Federal.

Patrícia Iglesias, destaca ainda que,

"O principal objetivo do princípio é a internalização das externalidades ambientais, ou seja, dos custos de prevenção dos danos. Permite-se que tais externalidades repercutam nos custos finais de produtos e serviços cuja produção seja poluente." (IGLECIAS, P., 2013, p. 52)

Fernandes, em seu artigo, apresenta uma análise interessante quando afirma que o princípio do poluidor-pagador:

"Está ligado, à utilização de recursos ambientais, tendo em vista serem escassos e que por tal devem ser utilizados de forma racional, mesmo estando dentro dos limites permitidos, vez que aquele que utiliza de recursos ambientais fora dos limites permitidos está comento um ilícito 
jurídico. Dai é que pode-se apontar uma conclusão, que este princípio não é uma licença para poluir, no qual a pessoa, seja ela física ou jurídica, possa entender que se ela paga pode poluir, vez que somente poderá explorar os recursos ambientais dentro do limite permitido". (FERNANDES, J.F., 2011, p.4)

Destaca ainda que, de acordo com o artigo $3^{\circ}$, inciso IV da Lei da Política Nacional do Meio Ambiente, o poluidor é aquele que causa degradação e não somente impacto ambiental. Com isso, considera que o poluidor é aquele que de alguma forma promove uma atividade fora dos limites permitidos.

De acordo com Fernandes, não se trata de um princípio de responsabilidade, que atue a posteriori, impondo ao poluidor pagamentos para ressarcir as vítimas de danos passados. Trata-se de um princípio que atua, sobretudo, a título de precaução e de prevenção, portanto antes e independentemente dos danos ao ambiente terem ocorridos.

\section{- Princípio da prevenção:}

O princípio está expresso no art. 225 da CF/1988, que impõe o dever de preservação do meio ambiente à coletividade e ao Poder Público. Há mecanismos preventivos do dano previstos na CF, como a exigência de estudo prévio de impacto ambiental nos casos de atividade potencialmente causadora de dano ao meio ambiente, o dever do Estado de controlar a produção, a comercialização e o emprego de técnicas, métodos e substâncias que impliquem risco para a vida, a qualidade de vida e ao meio ambiente, a preservação da diversidade e da integridade do patrimônio genético, além da previsão de participação popular, que, em audiências públicas, por exemplo, pode auxiliar na prevenção de danos.

Até mesmo a responsabilidade civil deve realmente ser preventiva, com base num sistema efetivo e exigente. A responsabilidade civil somente assume seu viés preventivo se o poluidor percebe que é mais barato prevenir do que reparar o dano. Enquanto isso não ocorrer, a opção do poluidor será sempre causar o dano, em vez de preveni-lo. (IGLECIAS, P., 2013, p. 53)

\section{- Princípio da precaução:}

O princípio 15 da Declaração do Rio sobre o Meio Ambiente (Conferências das Nações unidas sobre o Meio Ambiente e Desenvolvimento - ECO/92), estabelece que:

\footnotetext{
Com o fim de proteger o meio ambiente, o princípio da precaução deverá ser amplamente observado pelos Estados, de acordo com suas capacidades. Quando houver ameaça de danos graves ou irreversiveis, a ausência de certeza científica absoluta não será utilizada como razão para o adiamento de medidas economicamente viáveis para prevenir a degradação ambiental.
}

Seu principal foco está na antecipação, demonstrando a necessidade de medidas ambientais eficazes para que o dano não ocorra.

Para a aplicação do princípio deve haver séria e irreversível ameaça ao meio ambiente. O ônus da prova, em tais situações, é do empreendedor, que deve demonstrar que sua atividade não causará os indesejáveis danos ao meio ambiente. (IGLECIAS, P., 2013, p. 54) 
A Constituição Federal define as competências dos diversos Entes da Federação. De acordo com o Art. 30, compete aos Municípios:

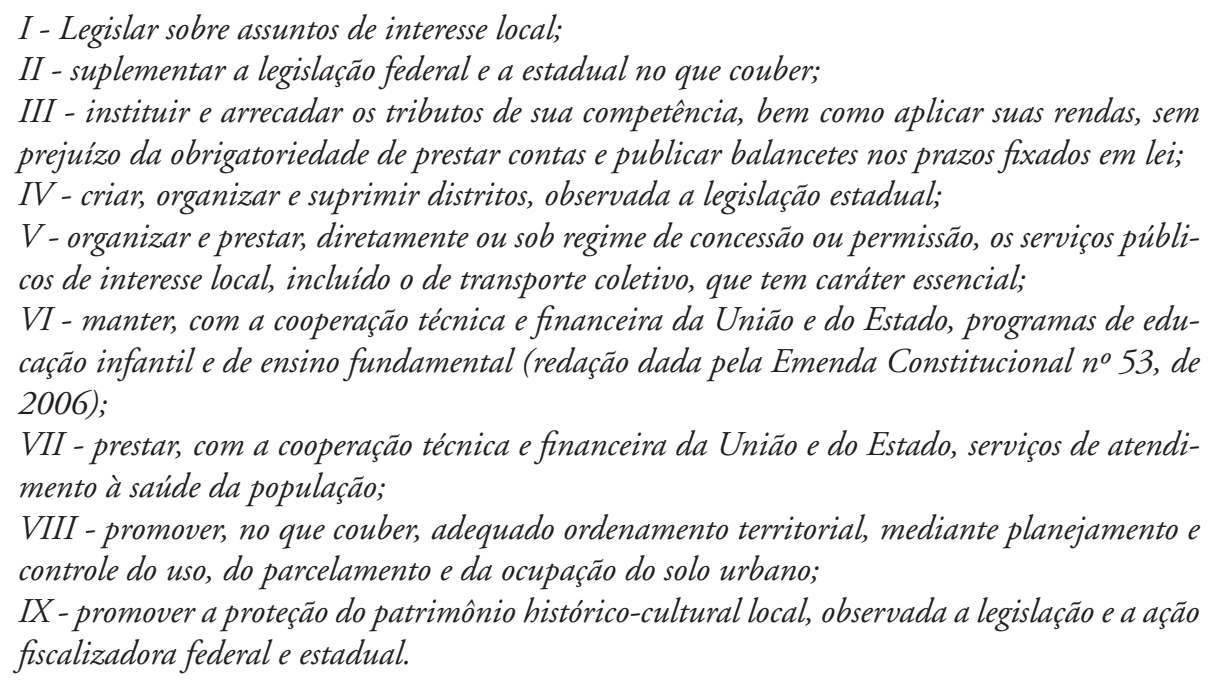

Define, ainda, em seu Artigo 182, a política de desenvolvimento urbano, executada pelo poder público municipal, conforme diretrizes gerais fixadas em lei, que tem por objetivo ordenar o pleno desenvolvimento das funções sociais da cidade e garantir o bem-estar de seus habitantes.

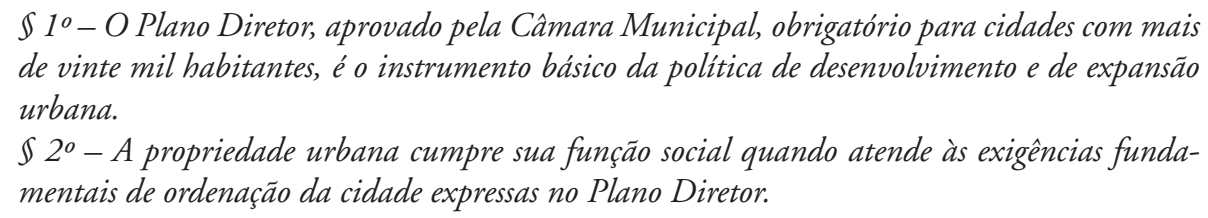

A Lei no 7.661/88, de 16 de maio de 1988, instituiu o Plano Nacional de Gerenciamento Costeiro (PNGC), que visa ordenar a ocupação dos espaços costeiros e estabelece que cada Estado e Município elaborem de forma participativa seu Plano de Gerenciamento, para organizar e administrar de forma integrada a utilização dos recursos naturais da zona costeira.

O Plano Nacional de Gerenciamento Costeiro foi institucionalizado no Brasil e é parte integrante da Política Nacional do Meio Ambiente (PNMA) e da Política Nacional de Recursos do Mar (PNRM), no qual orienta a utilização racional dos recursos da zona costeira, de forma a melhorar a qualidade de vida de sua população e a proteção do seu patrimônio natural, histórico, étnico e cultural.

Nessa ocasião, o Plano indicou de forma genérica os bens naturais a serem protegidos na zona costeira e definiu que a elaboração dos zoneamentos era de atribuição exclusiva dos Estados, sendo que sua conclusão constituiria pré-requisito para o desenvolvimento das demais ações. O PNGC considera a zona costeira o espaço geográfico formado por diversos ecossistemas de grande im- 
portância ambiental e de interface entre ar, mar e terra, que inclua os recursos renováveis ou não, abrangendo a faixa marítima e a faixa terrestre. ${ }^{45}$

Os objetivos fundamentais do Plano Nacional de Gerenciamento Costeiro é melhorar a qualidade de vida das populaçôes locais e promover proteção adequada aos ecossistemas, patrimônios naturais, históricos, étnicos e culturais das zonas costeiras, para usufruto permanente e sustentado das geraçôes presentes e futuras (o plano pode prever a criação de unidades de conservação permanente), além de definir:

- Normas gerais para proteger e administrar sistemas ambientais, formulando políticas, planos e programas, tanto na esfera estadual, quanto na municipal.

- Ordenar espacialmente o uso e ocupação dos recursos naturais.

- Gestão de forma integrada, descentralizada e participativa, a fim de identificar o potencial das atividades socioeconômicas das faixas terrestres e marítimas e garantir qualidade ambiental.

- Prever o zoneamento de usos e atividades, dando prioridade à conservação e proteção dos seguintes bens:

- Recursos naturais, renováveis e não renováveis.

- Recifes, parcéis, bancos de algas, ilhas costeiras e oceânicas.

- Sistemas fluviais, estuarinos-lagunares, baías e enseadas.

- Praias, restingas e dunas.

- Promontórios, costões e grutas marinhas.

- Florestas litorâneas, manguezais e pradarias submersas.

- Sítios ecológicos, unidades naturais importantes.

- Patrimônio natural.

O Plano Nacional de Gerenciamento Costeiro determina que para o licenciamento o órgão competente deverá solicitar ao responsável pelo empreendimento a elaboração do Estudo de Impacto Ambiental e a apresentação do respectivo Relatório de Impacto Ambiental.

O Plano considera também que as praias e o mar são bens de uso público e devem ter garantias de livre acesso, exceto em trechos considerados áreas de segurança nacional. Portanto, não é permitida a urbanização ou qualquer forma de utilização do solo na zona costeira que impeça ou dificulte o acesso à costa.

A lei prevê atualizações ao Plano através do Grupo de Coordenação, dirigido pela Secretaria da Comissão Interministerial para os Recursos do Mar.

\footnotetext{
45 A faixa marítima é a que se estende até 12 milhas marítimas, aproximadamente $22 \mathrm{~km}$, da linha de costa, de acordo com a Convenção das Nações Unidas sobre o Direito do Mar. A faixa terrestre é a faixa do continente formada pelos municípios que sofrem influência direta dos fenômenos da zona costeira. São os municípios em frente ao mar, localizados nas regióes metropolitanas litorâneas ou próximas a estas cidades, próximos ao litoral, até $50 \mathrm{~km}$ da linha de costa, com atividades ou infraestruturas de grande impacto ambiental sobre a zona costeira ou ecossistemas costeiros, e municípios estuarinos-lagunares.
} 
Dando prosseguimento à análise legal das leis brasileiras, a Figura 65 organiza no período de 1989 a 1994 o arcabouço jurídico brasileiro, estabelecido no âmbito dos governos da federação brasileira.

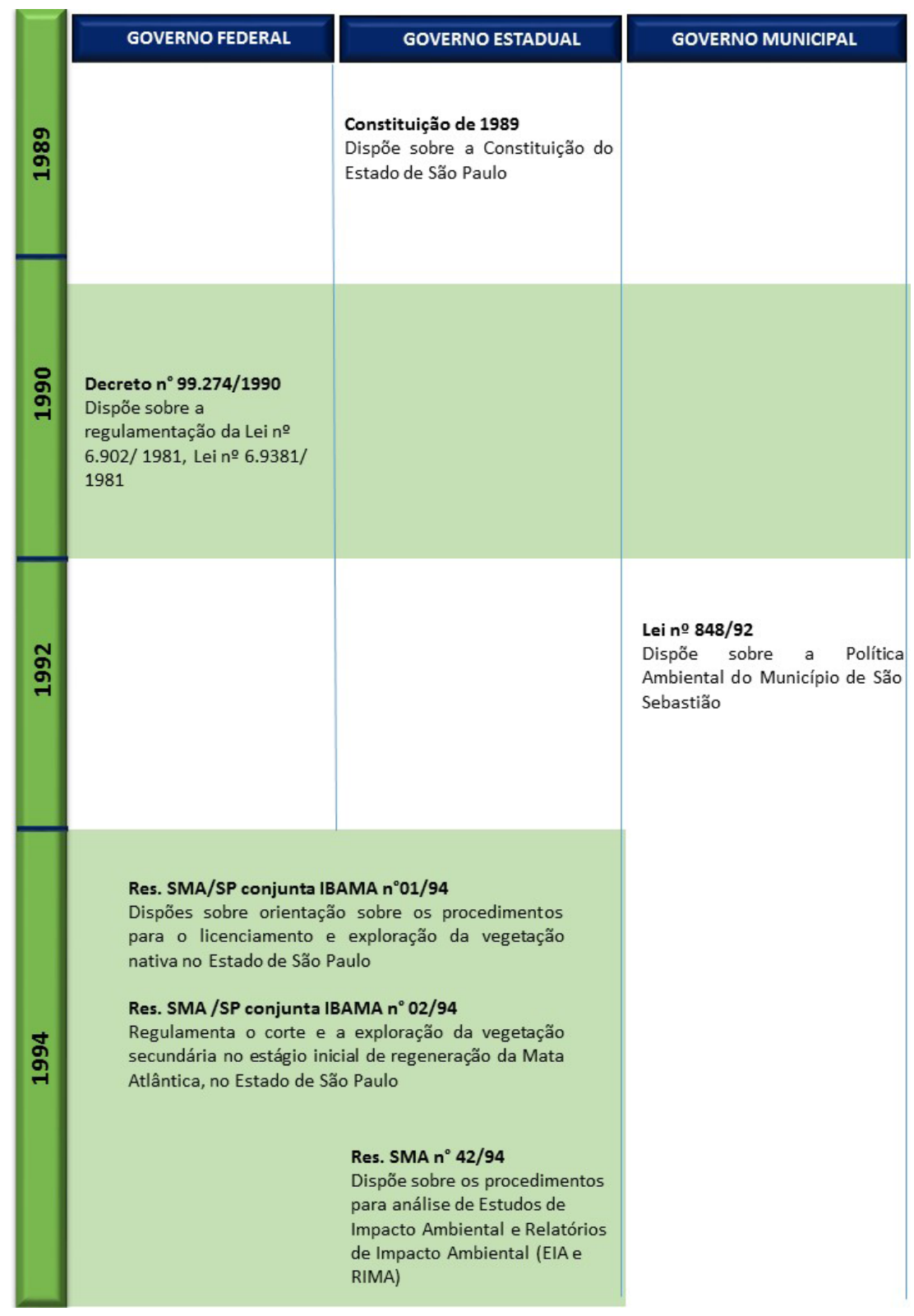

Figura 65 - Linha do tempo da legislação ambiental brasileira - período 1989 a 1994

\section{9}

A Constituição Estadual, Capítulo IV - Do Meio Ambiente, 1989, define que os Estados e Municípios, com a participação da coletividade, devem promover a preservação, conservação, defesa, recuperação e melhoria do meio ambiente natural e artificial, levando em consideração as características regionais, locais e a possibilidade do desenvolvimento social e econômico.

As obras que utilizam recursos naturais só podem ser autorizadas, tanto do setor público quanto do privado, desde que se comprove que o meio ambiente será mantido ecologicamente equilibrado. 
Para garantir a qualidade ambiental, proteção, controle e desenvolvimento com uso adequado dos recursos naturais, o Estado, segundo a Constituição, precisa criar um sistema de administração, levando em consideração os seguintes objetivos:

- Propor uma Política Estadual de proteção ao meio ambiente.

- Manter e promover o equilíbrio ecológico.

- Definir, implantar e administrar espaços territoriais.

- Monitorar a poluição e atividades potencialmente poluidoras.

- Informar a população sobre os níveis de poluição.

- Incentivar pesquisas para a resolução dos problemas ambientais.

- Estimular a pesquisa de fontes energéticas alternativas e não poluentes.

- Fiscalizar as entidades dedicadas à pesquisa e manipulação genética.

- Preservar e restaurar os processos ecológicos.

- Proteger a flora e a fauna.

- Promover a educação ambiental.

- Promover e manter o inventário e o mapeamento da cobertura vegetal.

- Estimular a recuperação da vegetação em áreas urbanas.

- Controlar e fiscalizar obras que possam causar degradação ambiental.

- Realizar o planejamento e o zoneamento ambiental.

A Constituição Estadual considera a Mata Atlântica, a Serra do Mar, a Zona Costeira, o Complexo Estuário-Lagunar (entre Iguape e Cananéia), os vales dos rios Paraíba, Ribeira, Tietê e Paranapanema e as unidades de conservação do Estado de São Paulo, espaços territoriais especialmente protegidos com sua utilização dependente de prévia autorização.

A Constituição Estadual considera também a proteção permanentemente dos manguezais, nascentes, mananciais, matas ciliares e áreas estuarinas e que abriguem exemplares raros da fauna e da flora, pouso ou reprodução de espécies migratórias, além das cavidades naturais subterrâneas e paisagens notáveis.

\section{0}

A Política Nacional de Meio Ambiente, após mais de uma década, foi regulamentada por meio do Decreto Federal no 99.274/1990, cujo principal objetivo foi fiscalizar, permanentemente, os recursos ambientais, visando à compatibilização do desenvolvimento econômico com a proteção do meio ambiente e do equilíbrio ecológico.

Para alcançar tais objetivos, o Decreto propôs proteger as áreas representativas de ecossistemas por meio da implantação de unidades de conservação e preservação ecológica, além de manter por meio de órgãos especializados da administração pública o controle permanente de atividades poluidoras e incentivar tecnologias para uso racional dos recursos ambientais. 
Também estabeleceu a importância de implantar um sistema permanente de acompanhamento dos índices locais da qualidade ambiental, identificando e informando áreas degradadas ou ameaçadas de degradação, com isto ampliando a educação ambiental da comunidade para maior defesa do meio ambiente.

Nos artigos 17, 18, 19, do capítulo IV do Decreto supracitado, definem-se os procedimentos necessários para licenciamento de atividades utilizadoras de recursos ambientais consideradas efetiva ou potencialmente poluidoras, bem como empreendimentos capazes de causar degradação ambiental, através de Estudos de Impacto Ambiental, contendo diagnóstico ambiental da área, descrição do projeto proposto, avaliação e previsão dos impactos significativos, tanto positivos quanto negativos.

A avaliação e aprovação desta documentação resultarão em três tipos de licença: a Licença Prévia (fase preliminar do planejamento), Licença de Instalação (autoriza a implantação) e a Licença de Operação (autoriza o seu funcionamento).

A seguir, a transcrição do Capítulo IV, Art.17, Art.18 e Art.19, do Decreto Federal No 99.274:

Capitulo IV - Do Licenciamento das Atividades

Art. 17 - A construção, instalação, ampliação e funcionamento de estabelecimento de atividades utilizadoras de recursos ambientais, consideradas efetiva ou potencialmente poluidoras, bem assim os empreendimentos capazes, sob qualquer forma, de causar degradação ambiental, dependerão de prévio licenciamento do órgão estadual competente integrante do SISNAMA, sem prejuizo de outras licenças legalmente exigiveis.

$\$ 1^{\circ}$ - Caberá ao CONAMA fixar os critérios básicos, segundo os quais serão exigidos estudos de impacto ambiental para fins de licenciamento, contendo, entre outros, os seguintes itens:

a) diagnóstico ambiental da área;

b) descrição da ação proposta e suas alternativas; $e$

c) identificação, análise e previsão dos impactos significativos, positivos e negativos.

$2^{\circ}$ - O estudo de impacto ambiental será realizado por técnicos habilitados e constituirá o Relatório de Impacto Ambiental RIMA, correndo as despesas à conta do proponente do projeto.

$3^{o}$ - Respeitada a matéria de sigilo industrial, assim expressamente caracterizada a pedido do interessado, o RIMA, devidamente fundamentado, será acessivel ao público.

$4^{o}$ - Resguardado o sigilo industrial, os pedidos de licenciamento, em qualquer das suas modalidades, sua renovação e a respectiva concessão da licença serão objeto de publicação resumida, paga pelo interessado, no jornal oficial do Estado e em um periódico de grande circulação, regional ou local, conforme modelo aprovado pelo CONAMA.

Art. 18 - O órgão estadual do meio ambiente e o Ibama, em caráter supletivo, sem prejuizo das penalidades pecuniárias cabiveis, determinarão, sempre que necessário, a redução das atividades geradoras de poluição, para manter as emissóes gasosas ou efluentes líquidos e os resíduos sólidos nas condiçôes e limites estipulados no licenciamento concedido.

Art. 19 - O Poder Público, no exercício de sua competência de controle, expedirá as seguintes licenças:

I-Licença Prévia (LP), na fase preliminar do planejamento de atividade, contendo requisitos básicos a serem atendidos nas fases de localização, instalação e operação, observados os planos municipais, estaduais ou federais de uso do solo;

II - Licença de Instalação (LI), autorizando o início da implantação, de acordo com as especificaçôes constantes do Projeto Executivo aprovado; $e$

III - Licença de Operação (LO), autorizando, após as verificaçôes necessárias, o início da atividade licenciada e o funcionamento de seus equipamentos de controle de poluição, de acordo com o previsto nas Licenças Prévias e de Instalação. 
1992

No âmbito municipal, a Prefeitura Municipal de São Sebastião, Estância Balneária do Estado de São Paulo, em atendimento ao disposto na Constituição Federal, no que tange o disposto no Art. 225, sancionou a sua Política de Meio Ambiente, Lei Municipal n 848/1992, organizando o sistema ambiental do município.

De acordo com o disposto no Art. $2^{\circ}$ :

O Sistema Municipal de Meio Ambiente, integrado ao SISNAMA - Sistema Nacional do Meio Ambiente, tem a seguinte composição: O Prefeito Municipal, com papel dirigente; a Secretaria de Meio Ambiente e Urbanismo, como órgão técnico e executivo; a Secretaria de Saúde; a Secretaria de Educação, a Secretaria de Serviços Urbanos, a Subprefeitura da Costa Sul, A Secretaria de Esportes e Cultura, e a Comissão de Defesa Civil, como órgãos setoriais; $O$ Conselho Municipal de Urbanismo e meio Ambiente (COMDURB) como órgão deliberativo sobre diretrizes de politica ambiental, diretrizes de licenciamento e fiscalização, diretrizes de educação ambiental, diretrizes sobre áreas protegidas, diretrizes sobre política de patrimônio histórico, e administração do Fundo Municipal do Meio Ambiente.

PARÁGRAFO ÚNICO - Fica criado na Secretaria de Urbanismo e Meio Ambiente, o Departamento de Meio Ambiente, com funçôes de planejamento e promoção ambiental, licenciamento ambiental e fiscalização, educação ambiental, limpeza pública, implantação e conservação de parques, mobiliário urbano, jardins e cemitérios. (SÃO SEBASTIÃO, ART. 2o)

Define ainda, em seu Capítulo IV, Artigo $5^{\circ}$ que:

O Estudo Prévio de Impacto Ambiental será exigido para concessão de autorização ambiental municipal para empreendimento, obras e atividades que apresentem significativo potencial de degradação ambiental, conforme o estabelecido na Resolução CONAMA 001/86 podendo o órgão Ambiental Municipal aprovar o estudo já realizado a nivel federal ou estadual, sendolhe facultado exigir outros peritos e novas audiências públicas. (SĀO SEBASTIĀO, ART. 5).

\section{4}

Considerando o disposto no art. 23, Incisos VI e VII da Constituição Federal, e a necessidade de se definir vegetação primária e secundária nos estágios pioneiro, inicial, médio e avançado de regeneração de Mata Atlântica, a fim de orientar os procedimentos de licenciamento de exploração da vegetação nativa no estado de São Paulo, foi publicado a Resolução Conjunta SMA/IBAMA 01/94 No 1, de 17/02/1994. Essa normativa orienta os procedimentos para o licenciamento e exploração da vegetação nativa no Estado de São Paulo, considerando vegetação primária aquela de máxima expressão local, com grande diversidade biológica.

A vegetação secundária é aquela em estágio de regeneração com diversidade biológica baixa e poucas espécies dominantes, que podem estar em estágio inicial, médio e avançado de regeneração.

No mesmo ano, foi publicado outra normativa conjunta, a Resolução Conjunta SMA IBAMA/ SP 02/94 No 2, de 12/05/1994, a qual regulamenta o corte e a exploração da vegetação secundária no estágio inicial de regeneração da Mata Atlântica, no estado de São Paulo, determinando as características especificas para conceder as autorizações (sempre em conformidade com o Plano Diretor 
aprovado e demais legislações municipais e ambientais), nas áreas urbanas, não efetivamente urbanizadas, com parcelamentos de solo aprovados, lotes ou terrenos para edificaçóes ou obras com fins urbanos, áreas verdes a serem mantidas e preservadas e áreas rurais.

A Secretaria Estadual de Meio Ambiente, diante da necessidade de regulamentar os procedimentos para análise dos Estudos de Impacto Ambiental e Relatórios de Impacto Ambiental (EIA e RIMA), com objetivo de orientar os pareceres e licenças ambientais a serem emitidas pela CETESB, publicou a Resolução SMA No 42/94, de 29/12/1994.

De acordo com essa resolução, para as licenças ambientais, a SMA define um roteiro de orientação ao interessado, para que elabore o Relatório Ambiental Preliminar (RAP). Sua análise definirá a necessidade ou não de um EIA-RIMA.

Caso seja necessário o EIA-RIMA, a SMA solicita ao empreendedor que promova uma audiência pública no início dos trabalhos e que apresente o plano de trabalho, explicitando a metodologia e o conteúdo dos estudos necessários à avaliação de todos os impactos ambientais envolvidos, que deverão ser entregues dentro dos prazos determinados pela Secretaria.

Uma nova audiência pública será necessária para apresentação do EIA-RIMA para informar e demonstrar a viabilidade ambiental do empreendimento. Se forem solicitadas revisóes, a SMA avalia e sugere as condiçōes para as diferentes etapas do licenciamento.

Os estudos serão encaminhados às câmaras técnicas do CONSEMA (possui o poder da deliberação final) que emitirá seu parecer após analisar o empreendimento, ouvindo os interessados, técnicos da SMA e demais segmentos sociais envolvidos com a questão. Aprovado o empreendimento pelo CONSEMA, a SMA emitirá a Licença Prévia, Licença de Instalação e Licença de Operação, fixando seus prazos de validade.

Diante da necessidade de consolidar parâmetros para análise da vegetação de restinga, o CONAMA publicou a Resolução do CONAMA n 007/96, de 23 de Julho de 1996. De acordo com a Resolução, o principal objetivo foi viabilizar a análise técnica da vegetação de restinga, de forma a identificar as possíveis fragilidades desse ecossistema que exerce papel fundamental na estabilização de dunas e mangues para a manutenção das drenagens naturais.

De acordo com a resolução, a vegetação de restinga é caracterizada pelo conjunto das comunidades vegetais sob influência marinha e fluvio-marinha e estão divididas em vegetação de praias e dunas, vegetação sobre cordões arenosos e vegetação associada às depressões.

Dando prosseguimento à análise legal das leis brasileiras, a Figura 66 organiza no período entre 1997 e 2002, o arcabouço jurídico brasileiro, estabelecido no âmbito dos governos da federação brasileira. 


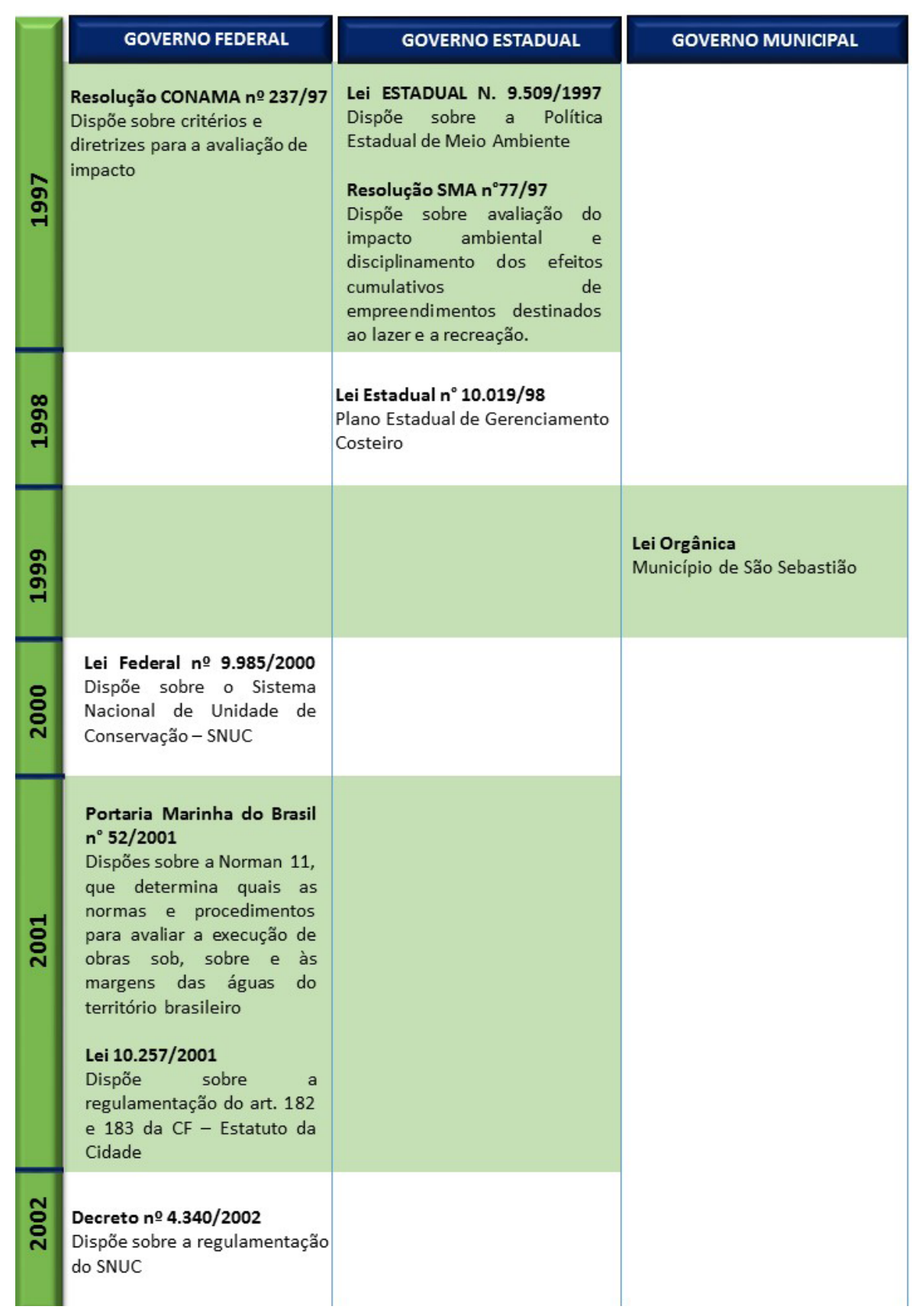

Figura 66 - Linha do tempo da legislação ambiental brasileira - período 1997 a 2002

1997

A Resolução do CONAMA n ${ }^{\circ}$ 237/97, de 19/12/1997, dispõe sobre a revisão e complementação dos procedimentos e critérios utilizados para o licenciamento ambiental.

A resolução revisa os procedimentos, define critérios para o licenciamento ambiental e prevê procedimentos simplificados para empreendimentos de baixo impacto ambiental.

Efetiva a utilização das licenças como instrumento de gestão para controlar a construção, instalação e ampliação de atividades que utilizem recursos naturais e sejam potencialmente poluidores (barragens, diques, marinas, portos e complexos turísticos e de lazer). 
As licenças dependerão de prévia aprovação do órgão ambiental, após a elaboração de Estudo de Impacto Ambiental, respectivo Relatório de Impacto Ambiental e declaração da Prefeitura Municipal, informando que o local e o tipo de empreendimento ou atividade pretendida estão em conformidade com as legislações vigentes no município.

De acordo com o art. 11 da Resolução, em seu parágrafo único, estabelece que:

O empreendedor e os profissionais que subscrevem os estudos previstos no caput deste artigo serão responsáveis pelas informaçôes apresentadas, sujeitando-se às sançôes administrativas, civis e penais. (Grifo nosso)

A ausência de licença caracteriza crime, nos termos da Lei 9.605/1998.

O art. 3. ${ }^{\circ}$ da Resolução Conama 237/1997 fixa a necessidade de publicidade do Relatório de Impacto Ambiental, determinando a realização de audiência pública, que, nos termos do art. $1 .^{\circ}$ da Resolução Conama 9/1987, "tem por finalidade expor aos interessados o conteúdo do produto em análise e do seu referido RIMA, dirimindo dúvidas e recolhendo dos presentes as críticas e sugestôes a respeito".

A audiência pública deve ser realizada pelo órgão de meio ambiente licenciador, quando julgar necessário ou quando solicitado por entidade civil, pelo Ministério Público ou por 50 ou mais cidadãos, conforme determina o art. 2. ${ }^{\circ}$ da Res. 09/1987. (IGLECIAS, Patrícia, 2013, p. 117)

O licenciamento prevê as seguintes espécies de licenças, nos termos da Resolução:

- Licença Prévia (LP) - fase preliminar do empreendimento. Aprova sua localização, concepção, viabilidade ambiental e estabelece os requisitos a serem atendidos. Máximo de cinco anos de validade.

- Licença de Instalação (LI) - autoriza a instalação do empreendimento e sugere medidas para o controle ambiental. Máximo de seis anos de validade

- Licença de Operação (LO) - autoriza a operação do empreendimento após a verificação do cumprimento das medidas de controle ambiental. Máximo de dez anos de validade.

\footnotetext{
A Licença Prévia é concedida na fase preliminar de planejamento do empreendimento ou atividade. Envolve a aprovação da sua localização e concepção, atestando a sua viabilidade ambiental, bem como o estabelecimento dos requisitos básicos e condicionantes a serem atendidos nas próximas fases.

A Licença de Instalação, como o próprio nome indica, autoriza a instalação do empreendimento ou atividade, de acordo com os planos, programas e projetos aprovados e inclui as medidas de controle ambiental e demais condicionantes, da qual constituem motivo determinante.

A Licença de Operação autoriza a operação da atividade ou empreendimento, após a verificação do efetivo cumprimento das exigências constantes das licenças anteriores, com as medidas de controle ambiental e condicionantes determinados para a operaçāo. (IGLECIAS, Patrícia, 2014, p.23)
}

O Estado de São Paulo sancionou a Lei Estadual n 9.509, de 20/03/1997, que dispõe sobre a Política Estadual do Meio Ambiente, seus fins e mecanismos de formulação e aplicação. De acordo com o disposto no Artigo $1^{\circ}$ : 
Esta lei estabelece a Politica Estadual do Meio Ambiente, seus objetivos, mecanismos de formulação e aplicação e constitui o Sistema Estadual de Administração da Qualidade Ambiental, Proteção, Controle e Desenvolvimento do Meio Ambiente e Uso Adequado dos Recursos Naturais - SEAQUA, nos termos do artigo 225 da Constituição Federal e o artigo 193 da Constituição do Estado. (SÃO PAULO, 1997)

A Política Estadual do Meio Ambiente tem por objetivo garantir a todos o direito ao meio ambiente ecologicamente equilibrado, bem de uso comum do povo e essencial à sadia qualidade de vida, visando assegurar, no estado, condições ao desenvolvimento sustentável, com justiça social, aos interesses da seguridade social e à proteção da dignidade da vida humana.

Define em seu Capítulo III, artigo 19, que a construção, instalação, ampliação e funcionamento de estabelecimentos e atividades utilizadoras de recursos ambientais, consideradas efetiva ou potencialmente poluidoras, bem como os empreendimentos capazes, sob qualquer forma, de causar degradação ambiental, dependerão de prévio licenciamento, no órgão estadual competente, integrante do SEAQUA (Sistema Estadual de Administração da Qualidade Ambiental, Proteção, Controle e Desenvolvimento do Meio Ambiente e Uso Adequado dos Recurso Naturais) sem prejuízo de outras licenças legalmente exigíveis.

Em complementação à Política Estadual de Meio Ambiente, a Secretaria Estadual do Meio Ambiente publicou a Resolução SMA no 77/97, de 24/11/1997, na qual considera a necessidade de avaliar o impacto ambiental e disciplinar os efeitos cumulativos de empreendimentos destinados ao lazer e à recreação, como os "parques temáticos", levando em conta sua localização, natureza do empreendimento (caráter permanente ou sazonal) e capacidade de atendimento. Acima de 10.000 mil pessoas/dia devem atender às exigências da Resolução SMA no 42/94 (os empreendimentos menores serão estudados pela SMA).

\section{8}

O Plano Estadual de Gerenciamento Costeiro, instituído pela Lei no 10.019/98, dispóe os objetivos, diretrizes, metas e instrumentos para sua elaboração, aprovação e execução, com a finalidade de disciplinar e racionalizar a utilização dos recursos naturais da zona costeira. A Lei Estadual definiu a tipologia das zonas costeiras, os seus usos permitidos, as atividades proibidas e as penalidades a serem aplicadas no caso de infrações.

A Lei estabeleceu que o licenciamento e a fiscalização deveriam ser realizados com base nas normas e critérios definidos pelo zoneamento ecológico econômico, a ser instituído mediante decreto estadual, sem prejuízo das demais normas estaduais, federais e municipais definidas pelos órgãos competentes.

O Plano Estadual de Gerenciamento Costeiro para o litoral paulista informa que a zona costeira é o espaço geográfico delimitado em terra pelo divisor de águas de drenagem atlântica e no mar pela isóbata 23,6 metros. Engloba todos os ecossistemas e recursos naturais existentes tanto em terra quanto nas faixas marinhas. 
O Plano de Ação e Gestão deve ser elaborado pelo Estado, Municípios e sociedade civil organizada, para definir o conjunto de projetos compatibilizados e integrados com as diretrizes estabelecidas no zoneamento ecológico econômico, que é o instrumento de planejamento, resultado das diversas análises ecológicas e socioeconômicas, estabelecidas a partir de discussões públicas sobre as recomendações técnicas para definir as normas de uso e ocupação do solo e manejo dos recursos naturais.

A Lei Estadual delimita quatro setores da Zona Costeira Paulista: Litoral Norte, Baixada Santista, Complexo Estuário-Lagunar de Iguape e Vale do Ribeira, como áreas a serem planejadas pelo Plano Estadual de Gerenciamento Costeiro. O principal objetivo é disciplinar e racionalizar a utilização dos recursos naturais, melhorar a qualidade de vida da população local e garantir preservação ambiental e proteção dos ecossistemas costeiros através das seguintes recomendações:

- Compatibilizar usos e atividades humanas.

- Garantir a fixação e desenvolvimento das populaçôes locais.

- Controlar o uso e ocupação do solo.

- Monitorar a exploração dos recursos naturais.

- Defender e restaurar ecossistemas representativos.

- Planejamento e gestão (deve funcionar de forma integrada e participativa).

- Definir o zoneamento ecológico econômico, com normas e diretrizes.

- Ações do governo com participação e consulta à população costeira.

- Aplicar o Sistema de Informações do Gerenciamento Costeiro.

Em 1998, a Lei n. ${ }^{0} 9.605$ apresenta os critérios e penalidades do crime ambiental para empreendimentos potencialmente poluidor que não obtiveram suas licenças ambientais.

A avaliação de impacto ambiental e do licenciamento é um instrumento preventivo de política e gestão ambiental mas que apresenta inúmeros problemas e insuficiências por falta de um planejamento mais amplo para avaliar os EIA individuais dentro deste contexto.

1999

No âmbito municipal, a Prefeitura Municipal de São Sebastião, Estância Balneária do Estado de São Paulo, publicou a Lei Orgânica do Município e Patrimônio Histórico de São Sebastião. De acordo com o Art. $3^{\circ}$, são objetivos fundamentais garantir os direitos humanos, colaborar com os governos federal e estadual na constituição de uma sociedade livre, justa e solidária, promover o bem-estar e o desenvolvimento da comunidade local, organizar e prestar diretamente ou sob o regime de concessão ou permissão os serviços públicos de interesse local.

Define também política de desenvolvimento urbano através da elaboração do Plano Diretor de Desenvolvimento Integrado para proteger e conservar o patrimônio público, documentos, obras e outros bens de valor histórico, artístico, turístico e cultural, de monumentos e de paisagens naturais notáveis. 
Busca criar condições para a proteção ao meio ambiente urbano e rural local e combater a poluição, em qualquer de suas formas, e outros tipos de degradação ambiental, observadas a legislação e a ação fiscalizadora federal e estadual.

O município valorizará e preservará o patrimônio cultural e natural, cuidando para que sejam respeitadas suas peculiaridades locais, assegurando o respeito ao meio ambiente.

Conforme disposto no Art. 151 e 152, o Canal de São Sebastiāo, a Mata Atlântica, a Serra do Mar, a zona costeira, as ilhas, as praias e os costôes rochosos, os manguezais e as restingas, localizados no território do município, são espaços territoriais especialmente protegidos. Sua utilização dependerá de prévia autorização e dentro de condições que assegurem a preservação do meio ambiente, vedada qualquer utilização que comprometa a integridade dos atributos que justifiquem sua proteção. Todos têm direito ao meio ambiente saudável e ecologicamente equilibrado, impondo-se em especial ao Poder Público Municipal o dever de defendê-lo, preservá-lo para o benefício das gerações atuais e futuras.

O Art. 155 determina que a execução de obras, atividades, processos produtivos, empreendimentos e a exploração de recursos naturais de qualquer espécie, quer pelo setor público quer pelo privado, serão admitidas se houver resguardo do meio ambiente ecologicamente equilibrado.

De acordo com o Art. 156, são consideradas áreas de proteção permanente: I - os manguezais; II - as nascentes e os mananciais; III - as matas primárias e a vegetação localizada nas encostas de morros e ao longo dos rios e estuários; IV - as ilhas de Alcatrazes, Toque-Toque Grande, ToqueToque Pequeno, Gatos, As Ilhas, Monte de Trigo, Das Couves e Ilhote do Camburi; V - aquelas que abrigam exemplares raros da fauna e flora e as que servem de local de pouso ou reprodução de espécies migratórias; VI - as áreas estuarinas; VII - as paisagens notáveis; VIII - a região de costão desde a Praia Grande até Boracéia, divisa do Município; IX - as encostas da Serra do Mar.

De acordo com os Art. 168 e 169, o Município exigirá do Estado uma compensação financeira sempre que o governo estadual criar espaços territoriais especialmente protegidos.

O Município poderá estabelecer convênio com outros municípios, objetivando a solução de problemas comuns relativos à proteção ambiental, em particular à preservação dos recursos hídricos e ao uso equilibrado dos recursos naturais, à infraestrutura de saneamento básico e à destinação final dos resíduos de qualquer natureza.

2000

Conforme discutido anteriormente, no final da década de 1980 a Resolução CONAMA no 10/1988, em seu artigo 1º, define que as Áreas de Proteção Ambiental (APA) são unidades de conservação destinadas a proteger e conservar a qualidade ambiental e os sistemas naturais ali existentes, visando a melhoria da qualidade de vida da população local e também objetivando a proteção dos ecossistemas regionais. Buscando atender os objetivos de criação, as APA terão sempre um zonea- 
mento ecológico econômico e estabelecerá normas de uso, de acordo com as condições locais bióticas, geológicas, urbanísticas, agropastoris, extrativistas, culturais e outras (Art. $2^{\circ}$ ).

Dando continuidade às políticas de conservação de áreas protegidas no Brasil, no caso das Unidades de Conservação a sua criação e implementação foi uma estratégia mundialmente utilizada visando a conservação dos recursos naturais e a busca da sustentabilidade ambiental, econômica e social.

O Sistema Nacional de Unidades de Conservação (SNUC), instituído pela Lei Federal no 9.985/2000 e regulamentado pelo Decreto Federal n 4.340/2002, estabeleceu critérios e normas para a criação e implementação de Unidades de Conservação (UC).

Na Tabela 4 é apresentado os grupos de Unidades de Conservação com características específicas, sendo os denominados de Proteção Integral e os de Uso Sustentável (art. 70).

\begin{tabular}{|c|l|}
\hline \multicolumn{2}{|c|}{ CATEGORIAS DE UNIDADES DE CONSERVAÇÃO } \\
\hline PROTEÇÃO INTEGRAL & \multicolumn{1}{|c|}{ USO SUSTENTÁVEL } \\
\hline Estação Ecológica & Área de Proteção Ambiental - APA \\
\hline Reserva Biológica & Área de relevante interesse ecológico \\
\hline Parque Nacional & Floresta nacional \\
\hline Monumento Natural & Reserva extrativista \\
\hline \multirow{2}{*}{ Refúgio de Vida Silvestre } & Reserva de fauna \\
\cline { 2 - 2 } & Reserva de desenvolvimento sustentável \\
\cline { 2 - 2 } & Reserva particular do patrimônio natural \\
\hline
\end{tabular}

Fonte: elaborado pelo autor, 2014.

Tabela 4 - Categorias de Unidades de Conservação por grupo

De acordo com a legislação federal, as Unidades de Proteção Integral são aquelas que têm por objetivo básico preservar a natureza, sendo admitido apenas o uso indireto, isto é, aquele que não envolve consumo, coleta, dano ou destruição dos recursos naturais. Este grupo é composto pelas seguintes categorias: (a) estação ecológica; (b) reserva biológica; (c) parque nacional; (d) monumento natural (e) refúgio de vida silvestres. (RODRIGUES,2005, p.86)

De acordo com a Lei Federal no 9.985/2000, as Unidades de Uso Sustentável são aquelas cujo objetivo básico é compatibilizar a conservação da natureza com o uso sustentável, entendido como a exploração do ambiente de maneira a garantir a perenidade dos recursos ambientais renováveis e dos processos ecológicos, mantendo a biodiversidade e os demais atributos ecológicos de forma socialmente justa e economicamente viável de parcela dos recursos naturais. Este grupo é constituído pelas seguintes categorias: (a) área de proteção ambiental; (b) área de relevante interesse ecológico; (c) florestas nacionais; (d) reserva extrativista; (e) reserva de fauna; (f) reserva de desenvolvimento sustentável; (g) reserva particular do patrimônio natural. (RODRIGUES,2005, p.86) 
No Estado de São Paulo, por meio do Sistema Estadual de Florestas, a Fundação Florestal, órgão gestor das Unidades de Conservação do Estado de São Paulo, passou a compartilhar a responsabilidade das unidades juntamente com o Instituto Florestal (IF). A implantação e gerenciamento dos programas de manejo nestas unidades ficaram a cargo da FF, enquanto o IF realiza e monitora atividades de pesquisa.

Atualmente, a Fundação Florestal gerencia as unidades de conservação do estado, cujo principal objetivo é promover e executar ações integradas voltadas para a conservação ambiental, a proteção da biodiversidade, o desenvolvimento sustentável, a recuperação de áreas degradadas e o reflorestamento, realizando parcerias com órgãos governamentais e instituições da sociedade civil. Também é responsável pela comercialização de produtos extraídos de florestas plantadas em áreas pertencentes ou possuídas pelo patrimônio do Estado.

Quanto aos recursos financeiros necessários para a implantação e gestão das unidades de conservação, a Lei 9.985/2000 contas com três dispositivos, conforme segue:

Segundo o art. 34 dessa Lei, os órgãos responsáveis pela administração das unidades de conservação podem receber recursos ou doações de qualquer natureza, nacionais ou internacionais, com ou sem encargos, provenientes de organizações privadas ou públicas ou de pessoas físicas que desejarem colaborar com a sua conservação. A administração dos recursos obtidos cabe ao órgão gestor da unidade, e estes serão utilizados exclusivamente na sua implantação, gestão e manutenção.

$\mathrm{O}$ art. 35 estabelece critérios para a aplicação dos recursos obtidos pelas unidades de conservação do Grupo de Proteção Integral mediante a cobrança de taxa de visitação e outras rendas decorrentes de arrecadação, serviços e atividades da própria unidade.

Terceiro e mais importante é o art. 36 da Lei 9.985/2000, que trata da chamada compensação ambiental SNUC. Esse dispositivo encontra-se regulamentado pelos arts. 31 a 34 do Dec. 4.340/2002 (cujas redaçōes foram alteradas pelo Dec. 6.848/2009). (IGLECIAS, Patrícia, op. Cit., 2013, p. 77)

Em qualquer caso, deve-se observar que a compensação ambiental tem lugar no âmbito do licenciamento ambiental de empreendimentos que causem significativo impacto ambiental negativo, assim considerado pelo órgão licenciador com base no EIA-RIMA.

\section{1}

Em conformidade com a Constituição Federal de 1988, cabe ao munícipio executar e gerir seu Plano Diretor, que é definido, pelo Capítulo II - Art. 182 da Carta Magna Brasileira, como instrumento básico da política de desenvolvimento e de expansão urbana, devendo objetivar o ordenamento a fim do pleno desenvolvimento das funções sociais da cidade, garantindo o bem-estar de seus habitantes. (BRASIL, 1988)

No advento da Lei Federal n. 10.257/2001, denominada Estatuto da Cidade, na execução da política urbana devem ser estabelecidas normas de ordem pública e interesse social, regulando o uso 
da propriedade urbana em prol do bem coletivo, da segurança e do bem-estar dos cidadãos e em prol do equilíbrio ambiental (BRASIL, 2011). Os planos diretores constituem, portanto, imposição legal, considerando que a conservação da função ecológica configura-se como dever constitucional do poder público em todas as suas esferas. (BRASIL, 1988)

Conforme disposto no art. $2^{\circ}$, a política urbana tem por objetivo ordenar o pleno desenvolvimento das funções sociais da cidade e da propriedade urbana, mediante as seguintes diretrizes gerais, das quais destacamos:

\footnotetext{
I - garantia do direito a cidades sustentáveis, entendido como o direito à terra urbana, à moradia, ao saneamento ambiental, à infraestrutura urbana, ao transporte e aos serviços públicos, ao trabalho e ao lazer, para as presentes e futuras geraçōes;

II - gestão democrática por meio da participação da população e de associações representativas dos vários segmentos da comunidade na formulação, execução e acompanhamento de planos, programas e projetos de desenvolvimento urbano.

VIII - adoção de padrōes de produção e consumo de bens e serviços e de expansão urbana compativeis com os limites da sustentabilidade ambiental, social e econômica do Município e do território sob sua área de influência.
}

O Estatuto da Cidade (Lei 10.257/2001) funciona como um dos instrumentos de gestão urbana (depende de regulamentação municipal). Avalia o impacto ambiental de empreendimentos e atividades privadas ou públicas em área urbana que dependerão de elaboração de estudo prévio de impacto de vizinhança (EIV) para obter as licenças ou autorizações de construção, ampliação ou funcionamento a cargo do Poder Público municipal. Não substitui a necessidade e aprovação do EIA.

O estudo deve contemplar efeitos positivos e negativos do empreendimento ou atividade quanto à qualidade de vida da população residente na área e suas proximidades analisando, no mínimo:

- Adensamento populacional.

- Equipamentos urbanos e comunitários.

- Uso e ocupação do solo.

- Valorização imobiliária.

- Geração de tráfego e demanda por transporte público.

- Ventilação e iluminação.

- Paisagem urbana e patrimônio natural e cultural.

Estudos de Impacto Ambiental buscam, através da análise da alteração da qualidade ambiental do local de inserção do empreendimento, estudar e avaliar, entre outros aspectos, alternativas locacionais e tecnológicas para inserção do empreendimento, com foco na sua relação com o meio.

O EIV analisa a relação que o empreendimento estabelecerá com a população potencialmente afetada, identificando efeitos prejudiciais à vizinhança, que não são contempladas pelos outros instrumentos e inclusive tem poder de lei para solicitar inviabilidade da atividade ou empreendimento.

Diante das fragilidades ambientes existentes na região costeira, a Marinha do Brasil, por meio do Departamento de Portos e Costas, publicou a Portaria No 52, de 4/09/2001, na qual estabeleceu a 
Norma 11 do Capítulo 01, que determina quais as normas e procedimentos para avaliar a execução de obras sob, sobre e às margens das águas do território brasileiro e emitir parecer padronizado ao ordenamento dos espaços aquaviários para garantir a segurança da navegação nas águas brasileiras.

O Ministério da Marinha exige o EIA-RIMA já analisado pelo órgão competente para que com estes documentos possa dar o seu parecer.

2002

Dois anos após a publicação da Lei no 9.985, de 18/07/2000, que dispõe sobre a Regulamentação do art. 225, $\$ 1^{\circ}$, incisos I, II, III e VII da Constituição Federal, e institui o Sistema Nacional de Unidades de Conservação da Natureza, alem de dar outras providências, foi decretado a sua regulamentação, por meio do Decreto Federal no 4.340/2002. Esse Decreto foi discutido, nesse trabalho, conjuntamente com a Lei 9.985, de 18/07/ 2000, portanto, encontra-se na legislação emitida em 2000, acima consolidado.

Dando prosseguimento, a Figura 67 organiza no período de 2006 a 2014 o arcabouço jurídico brasileiro, estabelecido no âmbito dos governos da federação brasileira.

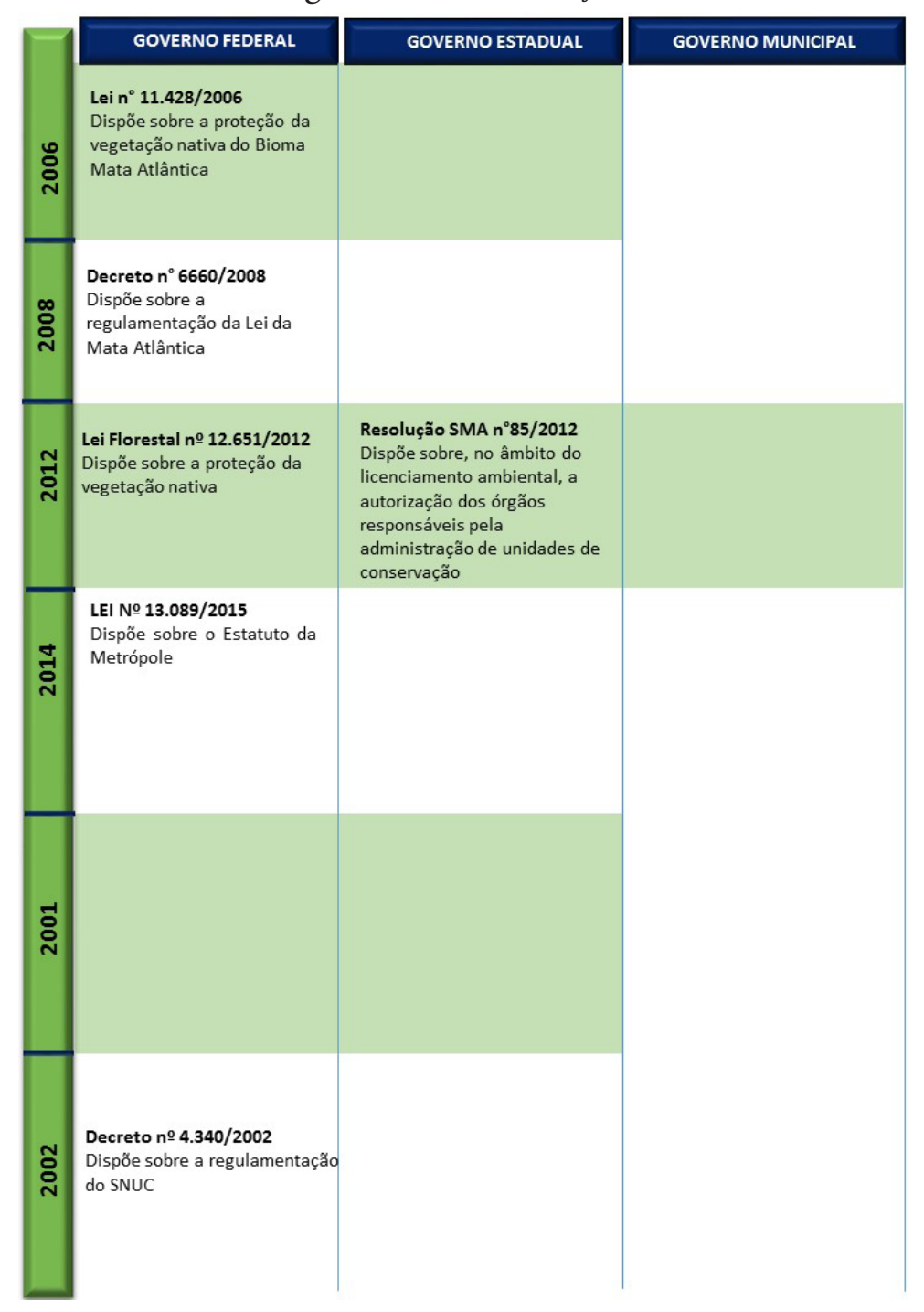

Figura 67 - Linha do tempo da legislação ambiental brasileira - período 2002 a 2014 


\section{$2006-2008$}

Conforme já discutido anteriormente, a Constituição da República, em seu artigo $225 \$ 4^{\circ}$, reconhece a Mata Atlântica como "patrimônio nacional", devendo sua utilização ocorrer dentro de condições que assegurem a preservação do meio ambiente. (BRASIL, 1988)

A defesa desse patrimônio natural foi instrumentalizada pela Lei 11.428, de 22/12/2006, a chamada Lei da Mata Atlântica (BRASIL, 2006). O referido disciplinamento, em seu art. 6, define que tanto a proteção como a utilização do bioma Mata Atlântica tem como objetivo o desenvolvimento sustentável em seu escopo mais amplo e, como objetivos específicos, salvaguardar a biodiversidade, a saúde humana, os valores paisagísticos, estéticos e turísticos, o regime hídrico e a estabilidade social. Em conformidade com a Lei da Mata Atlântica, a supressão de vegetação primária e secundária no estágio avançado de regeneração somente poderá ser autorizada em caso de utilidade pública e a vegetação secundária em estágio médio de regeneração nos casos de utilidade pública e interesse social. (BRASIL, 2006)

Com objetivo de normatizar o manejo das florestal de Mata Atlântica no país, a Lei da Mata Atlântica foi regulamentada pelo Decreto Federal no 6.660, de 21/11/2008, no qual o art. $1^{\circ}$ dispõe que o mapa do Instituto Brasileiro de Geografia e Estatística (IBGE), previsto no art. $2^{\circ}$ da Lei no 11.428 , de 22/12/2006, contempla a configuração original das seguintes formações florestais nativas e ecossistemas associados: floresta ombrófila densa; floresta ombrófila mista, também denominada de Mata de Araucárias; floresta ombrófila aberta; floresta estacional semidecidual; floresta estacional decidual; campos de altitude; áreas das formações pioneiras, conhecidas como manguezais, restingas, campos salinos e áreas aluviais; refúgios vegetacionais; áreas de tensão ecológica; brejos interioranos e encraves florestais, representados por disjunçôes de floresta ombrófila densa, floresta ombrófila aberta, floresta estacional semidecidual e floresta estacional decidual; áreas de estepe, savana e savana-estépica; e vegetação nativa das ilhas costeiras e oceânicas.

\section{2}

O terceiro Código Florestal, promulgado pelo Lei Federal no 12.651, de 25/05/2012, dispóe sobre a proteção da vegetação nativa e altera as Leis no 6.938, de 31/08/1981, no 9.393, de 19/12/1996, e no 11.428, de 22/12/2006; revoga as Leis no 4.771, de 15/09/1965, e no 7.754, de 14/04/1989, e a Medida Provisória no 2.166-67, de 24/08/2001; e dá outras providências.

A Lei estabelece normas gerais sobre a proteção da vegetação, áreas de Preservação Permanente e as áreas de Reserva Legal, a exploração florestal, o suprimento de matéria prima florestal, o controle da origem dos produtos florestais ,o controle e prevenção dos incêndios florestais e prevê instrumentos econômicos e financeiros para o alcance de seus objetivos.

Reforça o conceito de que florestas e vegetação nativa são bens de interesse comum (direito de propriedade e restrições dispostas em lei), e o comprometimento com a preservação do patrimônio vegetal e com a biodiversidade. 
De acordo com os Art. 61-A e 61-B, o tratamento é favorável àqueles que descumpriram o antigo Código de 1965 até 22/07/2008, com exigências mais brandas contidas agora no novo código.

A Lei determina que haja total preservação dos manguezais arbóreos em toda a sua extensão, definindo que os manguezais são ecossistemas importantíssimos como berçário de grande parte da vida marinha, incluindo pescado de elevado valor econômico. No entanto, ao mesmo tempo considera que podem ser suprimidos se forem considerados de utilidade pública.

De acordo com o disposto no Art. $3^{\circ}$, inciso VIII, são consideradas como de utilidade pública:

a) as atividades de segurança nacional e proteção sanitária;

b) as obras de infraestrutura destinadas às concessões e aos serviços públicos de transporte, sistema viário, inclusive aqueles necessários aos parcelamentos de solo urbano aprovados pelos municípios, saneamento, gestão de resíduos, energia, telecomunicações, radiodifusão, instalações necessárias à realização de competições esportivas estaduais, nacionais ou internacionais, bem como mineração, exceto, neste último caso, a extração de areia, argila, saibro e cascalho;

c) atividades e obras de defesa civil;

d) atividades que comprovadamente proporcionem melhorias na proteção das funções ambientais referidas no inciso II deste artigo;

e) outras atividades similares devidamente caracterizadas e motivadas em procedimento administrativo próprio, quando inexistir alternativa técnica e locacional ao empreendimento proposto, definidas em ato do chefe do poder no Executivo Federal.

O Poder Executivo da União, dos Estados e do Distrito Federal devem implantar no prazo máximo de dois anos Programas de Regulamentação Ambiental (PRA) a partir dos seguintes parâmetros:

- Reserva Legal (RL) - área de mata nativa que deve ser preservada dentro da propriedade. Na Amazônia Legal corresponde a $80 \%$ da propriedade, 35\% no cerrado e $20 \%$ em outras regiōes, mas ao mesmo tempo possibilita a redução da reserva para $50 \% \mathrm{em}$ estados com mais de 65\% das suas áreas em reservas ambientais, desde que autorizada pelo Conselho Nacional do Meio Ambiente

- Áreas de Preservação Permanente (APP) - Locais vulneráveis, como beira de rios, topo de morros e encostas, que não podem ser desmatados. Atualmente, produtores devem recompor 30 metros de mata ciliar para rios com até 10 metros de largura. A nova lei reduz para 15 metros. Ampliação dos mecanismos de incentivos econômicos ao produtor rural para garantir a preservação do meio ambiente: pagamento ao agricultor que preserva matas nativas, conservar a beleza cênica natural, conservar a biodiversidade, preservar a regulação do clima, manter a Área de Preservação Permanente (APP) e de reserva legal.

- Cadastro Ambiental Rural (CAR) - permitirá fiscalização efetiva do cumprimento das exigências legais, delimitando permanentemente as áreas destinadas às APP e RL. 
2014

A Lei Federal no 13.089 , de 12/01/2015, institui o Estatuto da Metrópole e altera a Lei no 10.257 , de 10/07/2001.

O Estatuto da Metrópole, lei que estabelece diretrizes gerais para o planejamento, a gestão e a execução das funções públicas de interesse comum em regiões metropolitanas e em aglomerações urbanas, agora é uma realidade. A nova lei fixa normas gerais sobre o plano de desenvolvimento urbano integrado e critérios para o apoio da União a ações que envolvem governança inter federativa - compartilhamento de responsabilidades e ações entre entes da Federação - no campo do desenvolvimento urbano.

De acordo com o disposto no $₫ 2^{\circ}$ :

(...) serão observadas as normas gerais de direito urbanistico estabelecidas na Lei no 10.257, de 10 de julho de 2001 - Estatuto da Cidade, que regulamenta os arts. 182 e 183 da Constituição Federal e em outras leis federais, bem como as regras que disciplinam a política nacional de desenvolvimento urbano, a politica nacional de desenvolvimento regional e as politicas setoriais de habitação, saneamento básico, mobilidade urbana e meio ambiente.

Em seu Capítulo III, Art. $6^{\circ}$, define que a governança inter federativa das regiões metropolitanas e das aglomerações urbanas respeitará os seguintes princípios:

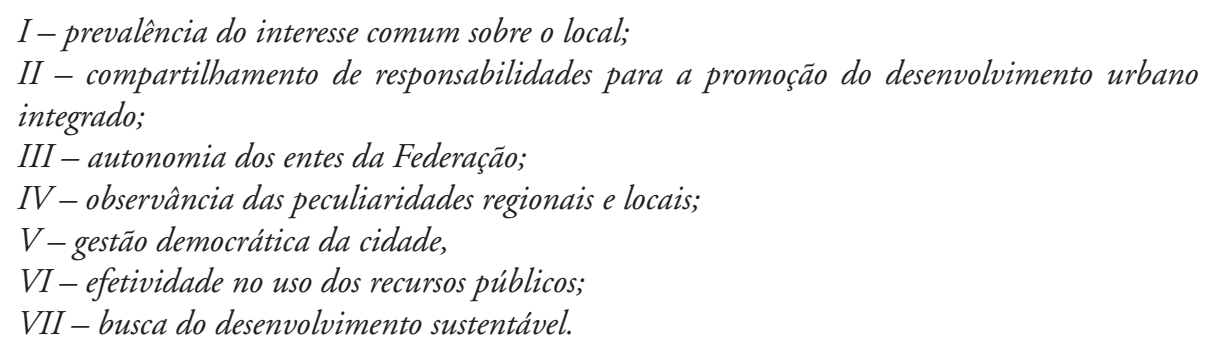

Em seu Capítulo IV, Art. $9^{\circ}$, determina que no desenvolvimento urbano integrado de regiôes metropolitanas e de aglomerações urbanas serão utilizados, entre outros, os seguintes instrumentos:

I-plano de desenvolvimento urbano integrado;

II - planos setoriais inter federativos;

III - fundos públicos;

$I V$ - operaçôes urbanas consorciadas inter federativas;

$V$ - zonas para aplicação compartilhada dos instrumentos urbanísticos previstos na Lei no

10.257, de 10 de julho de 2001;

$V I$ - consórcios públicos,

VII - convênios de cooperação;

VIII - contratos de gestão;

IX - compensação por serviços ambientais ou outros serviços prestados pelo Município à uni-

dade territorial urbana.

$X$-parcerias público-privadas inter federativas. 
A lei estadual que institui o plano de desenvolvimento urbano integrado de região metropolitana ou de aglomeração urbana deverá ser revista, pelo menos, a cada dez anos. (BRASIL, 2015, Art. 11. )

O Capítulo V, Art. 13, define que em suas ações inclusas na política nacional de desenvolvimento urbano, a União apoiará as iniciativas dos Estados e dos Municípios voltadas à governança inter federativa, observados as diretrizes e os objetivos do plano plurianual, as metas e as prioridades fixadas pelas leis de diretrizes orçamentárias e o limite das disponibilidades propiciadas pelas leis orçamentárias anuais.

De acordo com a Lei, a aplicação dos dispositivos legais impostos pela referida lei será coordenada pelos entes públicos que integram o Sistema Nacional de Desenvolvimento Urbano (SNDU), assegurando-se a participação da sociedade civil. (BRASIL, 2015, Art. 20.)

Independentemente das disposições desta Lei, os Municípios podem formalizar convênios de cooperação e constituir consórcios públicos para atuação em funções públicas de interesse comum no campo do desenvolvimento urbano, observada a Lei no 11.107, de 6/04/05. (BRASIL, 2015, 2005. Art. 23)

Define também que, nas regiōes metropolitanas ou nas aglomerações urbanas instituídas por lei complementar estadual, poderão ser realizadas operações urbanas consorciadas inter federativas, aprovadas por leis estaduais específicas.

\section{Considerações finais sobre a legislação ambiental}

A legislação atual que rege a utilização dos territórios costeiros demonstra grande preocupação em preservar a fauna e flora, em controlar a poluição (terra, ar e água) e garantir a qualidade e preservação do meio ambiente, ${ }^{46}$ preocupação presente na maioria das leis estudadas anteriormente, através de exigências como, preservar, planejar, disciplinar, racionalizar, ordenar a ocupação do território, com a utilização racional dos recursos naturais e a necessidade de EIA-RIMA para licenças ambientais aos novos empreendimentos com grande possibilidade de impacto negativo e poluidor.

Podemos observar também a preocupação em educar a população para a defesa do meio ambiente, através de programas de educação ambiental.

Em relação às praias, a legislação afirma que são bens públicos e o acesso a elas e ao mar devem ser livres, em qualquer sentido e direção. Portanto, não permitir a urbanização que impeça ou dificulte o acesso à costa deve ser um objetivo.

Para obras como a ampliação do porto de São Sebastião, a legislação brasileira está procurando condicionar as aprovações e autorizações (Licença Prévia, Licença de Instalação e Licença de Operação) desde que o EIA-RIMA, necessários tanto no âmbito Federal quanto no Estadual, comprovem

${ }^{46}$ Esta situação acabou produzindo uma legislação altamente restritiva e que necessita ser modernizada e simplificada para permitir o desenvolvimento sustentável das zonas costeiras, principalmente para a construção de novas estruturas de apoio à navegação. 
a manutenção da qualidade do meio ambiente e dos recursos naturais, minimizando os impactos ambientais e ampliando a capacidade em promover desenvolvimento econômico e social, com melhoria nas condiçõoes de vida, principalmente da população local (Lei n ${ }^{\circ}$.661/88).

A legislação também poderia ser mais clara e exigente na preservação da acessibilidade pública aos territórios fronteiros à linha d'água, através da requalificação de zonas portuárias.

O Estatuto da Cidade, Lei Federal 10.257/01, de 10/07/2001, é um instrumento legal que pode colaborar na regulamentação e uso das zonas próximas à linha d'água, garantindo de forma sustentável a qualidade ambiental e a permeabilidade urbana nestes territórios.

Através dos Planos Diretores municipais, o Estatuto da Cidade permite às operações urbanas, a outorga onerosa, a transferência do direito de construir e, se bem gerenciados, poderão estar compatibilizados com a ordenação das cidades e das características exclusivas desses locais. Estas ações poderão viabilizar a sustentabilidade urbana para estes espaços, com caráter de uso coletivo e permanente acesso às frentes marítimas.

São necessárias regras específicas para garantir as possibilidades espaciais destes territórios com características importantes ambientalmente, a partir da conservação e preservação do meio ambiente, da formulação de programas adequados à escala e aos interesses locais, utilizando suas potencialidades como motivos fundamentais desta nova ordenação territorial. Portanto, os EIA-RIMA devem estar subordinados a uma definição maior de planejamento.

Não basta apenas o EIA-RIMA atestar a qualidade e pertinência do empreendimento. Não podemos nos esquecer que o empreendedor é quem paga os estudos que sempre atestará a grande vantagem econômica, social e até ambiental de seu empreendimento.

Se houver também o interesse do Estado em sua viabilidade, que é o caso da ampliação do porto de São Sebastião, os estudos terão o aval do poder público e possivelmente terá a análise dos técnicos priorizada, sem muitos questionamentos e sem possibilidade de confrontar informações recebidas.

Além disto, nas audiências públicas, obrigatórias por lei, o empreendedor, através de sua equipe contratada, apresenta o trabalho com as principais decisões já tomadas e definidas, com pouca condição da sociedade civil organizada influenciar verdadeiramente nos encaminhamentos do projeto e até na não execução do empreendimento.

O empreendedor cumpre com a sua obrigatoriedade legal, alegando que as consultas públicas foram feitas, mas na verdade pouco ou nada é incorporado nos trabalhos.

O estudo de impacto ambiental caminha e acaba sendo aprovado pelo órgão licenciador, que libera as licenças ambientais, mas invariavelmente elas passam a ser questionadas pela justiça.

Recentemente diversos empreendimentos espalhados pelo Brasil tiveram suas licenças ambientais questionadas e cassadas pelo Ministério Público, principalmente por falta de clareza dos EIA, por não respeitarem a legislação ambiental, insuficiência nos dados e estudos apresentados, falta de estudos sinergéticos e por minimizarem os verdadeiros impactos negativos causados no meio am- 
biente e reais ameaças ao equilíbrio ambiental. A seguir, alguns do Estudos de Impacto Ambiental que foram questionados pela justiça:

- EIA - Trecho oeste do Rodoanel Mário Covas - São Paulo - 2006.

- $\quad$ EIA - Siderúrgica MMX - Mato Grosso do Sul - 2007.

- EIA - Expresso aeroporto e do trem de Guarulhos - São Paulo- 2009.

- EIA - Ampliação do Aeroporto de Guarulhos - São Paulo - 2009.

- $\quad$ EIA - Estaleiro OSX em Florianópolis - Santa Catarina - 2010.

- EIA - Ampliação do Porto de Suape ${ }^{47}$ - Recife - 2010.

- $\quad$ EIA - Usina hidrelétrica de Belo Monte - Pará em 2012.

- EIA - Termelétrica Porto do Itaqui - Maranhão - 2012.

- $\quad$ EIA - Construção do novo autódromo - Rio de Janeiro - 2013.

- $\quad$ EIA - Complexo industrial portuário do Açu - Rio de Janeiro - 2013.

- EIA - Construção do rodoanel de Teresina - Piauí - 2014.

- EIA - Exploração e produção da camada pré-sal - 2014.

Em São Sebastião, a Licença Prévia (LP) liberada pelo IBAMA para ampliação do porto de São Sebastião - Licença Prévia No 474/2013 emitida pelo IBAMA em 17/12/2013, que autorizou o desenvolvimento dos projetos para as fases 1 e 2 do projeto do Porto de São Sebastião para a ampliação de $800 \mathrm{mil} \mathrm{m}^{2}$ destinadas ao retroporto, projeto dos berços 2, 3 e 4 (300 m de comprimento por $40 \mathrm{~m}$ de largura, profundidade mínima de $16 \mathrm{~m}$ ) para navios com capacidade de até nove mil TEU, projeto da base de apoio offshore, com $117.590 \mathrm{~m}^{2}$ e dez berços de embarcaçóes (transporte de cargas e tripulações para as plataformas de petróleo), projeto do terminal multicargas (252.229 $\mathrm{m}^{2}$ ) para operação de veículos e cargas gerais, projeto do portão de acesso, projeto de interligação ao contorno viário sul e estacionamentos dos caminhōes que utilizaram o porto.

As contrapartidas exigidas pela licença expedida foram o monitoramento da qualidade ambiental do porto organizado, contratação e formação de mão de obra local, gerenciamento ambiental das obras, gerenciamento de riscos e controle de emergências, plano de comunicação social, melhorias viárias do contorno sul e duplicação da rodovia dos Tamoios.

A contestação e suspenção da LP foi feita pelo Ministério Público Federal ${ }^{48}$ e Ministério Público do Estado de São Paulo em caráter liminar pelo juiz Ricardo de Castro Nascimento, da Justiça Federal de Caraguatatuba (SP), em 11/07/2014, e foi acatada pela Justiça, sob alegação de risco real ao ecossistema da região, ausência de medidas compensatórias proporcionais ao dano ambiental

\footnotetext{
47 Esta situação acabou produzindo uma legislação altamente restritiva e que necessita ser modernizada e simplificada para permitir o desenvolvimento sustentável das zonas costeiras, principalmente para a construção de novas estruturas de apoio à navegação.

48 Fonte: <http://economia.estadao.com.br/noticias/geral,licenca-ambiental-trava-ampliacao-de-porto-imp-, 1530449>. Acesso em: 18/07/2014.
} 
causado e fundamentalmente ausência de estudos de impactos cumulativos e sinérgicos e incorreta definição das áreas de influência direta e indireta do empreendimento.

Portanto, ações como estas serão sempre uma realidade se não houver um planejamento mais amplo que tenha como objetivo manter a qualidade ambiental nestes territórios litorâneos de grande interesse econômico, mas que também considere as limitações do meio natural através da identificação de sua capacidade de suporte, planejando e gerenciando a correta utilização do território marinho e terrestre. 
Gerenciamento costeiro do Litoral Norte

Faixa litorânea - espaço finito 
$\Lambda_{\text {apenas } 8 \% \text { do total da superfície terrestre. Estas faixas territoriais, delimitadas até } 60 \mathrm{~km} \text { no }}$ sentido interior da linha de costa, concentram atualmente $60 \%$ da população mundial e é o espaço geográfico de interface entre mar e terra onde estão presentes ecossistemas de grande importância ambiental e, ao mesmo tempo, extremamente frágil.

As previsões indicam que até o ano de 2025 80\% da população mundial já estará vivendo em zonas costeiras ou próximas a elas.

Para manter a qualidade ambiental nestas faixas territoriais, e ao mesmo tempo promover o desenvolvimento econômico e social e compatibilizar os diversos interesses (portos comerciais, pesca, estruturas de apoio às embarcações de recreio, turismo náutico, transporte hidroviário, lazer, habitação, comércio, serviços, indústrias, pesquisas, contemplação entre outros usos), são fundamentais os conhecimentos relacionados ao meio natural, assim como identificar sua capacidade de suporte. Estes procedimentos são importantes para planejar e gerenciar a mais adequada e equilibrada utilização do território marinho e terrestre. O envolvimento e a compatibilização dos interesses nas três esferas de poder, Federal, Estadual e Municipal, em conjunto com a sociedade civil organizada e iniciativa privada, são vitais para atingir a melhor qualidade de utilização das zonas costeiras.

Por isso é necessário o desenvolvimento e aperfeiçoamento de instrumentos políticos que sejam capazes de regular os interesses econômicos em benefício da qualidade ambiental e da manutenção dos recursos naturais e, quando utilizado, incorpore estas considerações na nova ordenação espacial do litoral. ${ }^{49}$

No Brasil, as políticas ambientais relacionadas ao controle, preservação, monitoramento, regulamentação na utilização dos recursos naturais, metas ambientais, definição dos usos permitidos e outras medidas para os territórios costeiros são definidas principalmente pelos seguintes instrumentos legais: Política Nacional de Gerenciamento Costeiro ${ }^{50}$ (PNGC), Plano de Gestão da Zona Cos-

\footnotetext{
${ }^{49}$ Aqui estão presentes as oportunidades para definir as regras de utilização dos territórios fronteiros às águas e garantir por lei a permeabilidade destes espaços com as suas frentes litorâneas, por exemplo.

${ }^{50}$ Ordena a ocupação dos espaços costeiros e estabelece que cada Estado e Município elaborem de forma participativa seu Plano de Gerenciamento, para organizar e administrar de forma integrada a utilização dos recursos naturais da zona costeira - Lei $n^{\circ} 7661 / 88$.
} 
teira $^{51}$ (PGZC), Política Estadual de Gerenciamento Costeiro do Estado de São Paulo ${ }^{52}$ (PEGC), Política Municipal de Gerenciamento Costeiro ${ }^{33}$ (PMGC), Zoneamento Ecológico-Econômico Costeiro $^{54}$ (ZEEC), Sistema de Informação do Gerenciamento Costeiro ${ }^{55}$ (SIGERCO), Sistema de Monitoramento Ambiental da Zona Costeira ${ }^{56}$ (SMA-ZC), Relatório de Qualidade Ambiental da Zona Costeira ${ }^{57}$ (RQA-ZC), Decreto no 4.297/02, ${ }^{58}$ Decreto no 5.300/0459 e Decreto Estadual no $49.215 / 04^{60}$

\subsection{Plano de Gerenciamento Costeiro do Estado de São Paulo}

Secretaria do Meio Ambiente do Estado de São Paulo, a partir de 1987, em parceria com o
Governo Federal e fundamentado pelo Plano Nacional de Gerenciamento Costeiro (PNGC),

\footnotetext{
${ }^{51}$ Conjunto de ações articuladas e localizadas, com participação da sociedade, para orientar a execução do Gerenciamento Costeiro através das seguintes etapas de trabalhos: levantamento dos problemas, diretrizes/objetivos e plano de ações.

${ }^{52}$ Plano de Gerenciamento Costeiro do Estado de São Paulo.

${ }^{53}$ Especificação do PEGC onde o Município fica responsável pelo desenvolvimento e implantação do Plano de Gerenciamento Costeiro.

${ }^{54}$ Estabelece o limite sustentável e ocupação da zona costeira em função do potencial socioeconômico e da fragilidade ambiental através do diagnóstico físico-natural, diagnóstico socioeconômico, diagnóstico socioambiental e zoneamento proposto.

55 Banco de dados, mapas e informações digitalizadas integradas aos diversos Planos de Gerenciamento Costeiro do território brasileiro.
}

${ }^{56}$ Levantamento de dados e informações de forma contínua e sistemática para monitorar e fiscalizar a qualidade socioambiental da zona costeira. Suporte para atualizar as informações do SIGERCO.

${ }^{57}$ Monitoramento ambiental através de relatórios anuais para informar, avaliar ações implantadas e planejar futuras medidas.

${ }^{58}$ Estabelece que o Zoneamento Ecológico Econômico do Brasil - ZEE é um instrumento de organização do território, com ampla participação democrática, a ser seguido obrigatoriamente pelo setor público e privado, que valoriza o conhecimento científico multidisciplinar como elemento fundamental para auxiliar e disciplinar o crescimento econômico e a proteção dos recursos naturais em favor das presentes e futuras gerações. Seu principal objetivo é garantir o desenvolvimento sustentável e melhores condições de vida das pessoas, através de medidas e padrões de proteção ambiental com a finalidade de assegurar a qualidade ambiental (recursos hídricos e do solo) e a conservação da biodiversidade, mantendo o capital e os serviços ambientais dos ecossistemas. Deixa claro que o zoneamento, na distribuição das suas atividades econômicas, precisa considerar a importância ecológica, limitaçôes e fragilidades dos ecossistemas para estabelecer critérios de exploração do território considerando restriçōes e até a realocação de atividades que sejam incompatíveis com diretrizes já estabelecidas para proporcionar sustentabilidade ecológica, econômica e social.

${ }^{59}$ Estabelece os limites, princípios, objetivos, instrumentos e competências para a gestão ambiental, bem como as regras de uso e ocupação da zona costeira, especialmente da orla marítima, estabelecendo as bases para a formulação de políticas, planos e programas federais, estaduais e municipais.

${ }^{60}$ Dispõe sobre o Zoneamento Ecológico Econômico do Setor do Litoral Norte, prevê usos e atividades para as diferentes zonas, estabelece diretrizes, metas ambientais e socioeconômicas. 
iniciou o programa de gerenciamento costeiro do litoral de São Paulo ${ }^{61}$ para definir a melhor utilização dos recursos naturais terrestres e marinhos nos diversos municípios, com o objetivo de melhorar a qualidade de vida de sua população e a proteção do seu patrimônio natural, histórico, étnico e cultural.

A região foi separada em quatro áreas de planejamento: Vale do Ribeira, Complexo Estuário-Lagunar de Iguape, Baixada Santista e Litoral Norte. ${ }^{62}$

A proposta para o gerenciamento integrado destas quatro grandes áreas, através do trabalho conjunto entre os municípios e a sociedade civil organizada, procurou estabelecer qual o zoneamento mais adequado, as normas de uso e ocupação do solo e o manejo dos recursos naturais, considerando sua realidade socioeconômica e principalmente o potencial ecológico de cada setor.

Para um maior controle dos trabalhos, foi previsto a montagem de um banco de dados para o monitoramento de todo o Sistema de Informações do Gerenciamento Costeiro do Estado de São Paulo, SIGERCO/SP.

A Secretaria do Meio Ambiente-SP elaborou o anteprojeto de Lei para o Plano de Gerenciamento Costeiro do Estado de São Paulo, regulamentado pela Lei n ${ }^{\circ} 10.019$, de 3/07/1988, que estabeleceu os objetivos e diretrizes para os planos específicos de cada Zona Costeira Paulista.

A Lei Estadual no 10. 019, de 03/07/1998, que institui o Plano Estadual de Gerenciamento Costeiro para o Estado de São Paulo considerou que a zona costeira é o espaço geográfico delimita-

${ }^{61}$ Principais características da Zona Costeira Paulista:

- Extensão de $700 \mathrm{~km}$ de costa.

- $\quad$ Área $=27.000 \mathrm{Km}^{2}$.

- 36 municípios.

- 2 milhōes de habitantes, sem considerar a população flutuante.

- Possui grande parte da Mata Atlântica restante no Estado de São Paulo.

- Região serrana contínua e planícies à beira-mar.

- Alta declividade das encostas da Serra.

- Alto índice pluviométrico.

- Grandes e rápidas urbanizações nos últimos anos foram responsáveis por graves problemas ambientais e sociais. A falta de planejamento, normas e diretrizes de ocupação permitiram esta realidade.

${ }^{62}$ As principais características das quatro Zonas Costeiras são:

Vale do Ribeira: Com área de $13.243 \mathrm{~km}^{2}$. Sem contato direto com a linha costeira.

Abrange os seguintes municípios: Apiaí, Barra do Turvo, Barra do Chapéu, Cajati, Eldorado, Iporanga, Itaóca, Itariri, Itapirapuã Paulista, Jacupiranga, Juquiá, Miracatu, Pariquera-Açú, Pedro de Toledo, Registro, Ribeira, Sete Barras e Tapiraí.

Principais características econômicas: agricultura de várzea e de encosta.

Complexo Estuário-Lagunar: 210 km de extensão litorânea e área de 3.287 km².

Abrange os seguintes municípios: Iguape, Cananeia e Ilha Comprida.

Principais características econômicas: pesca e aqüicultura.

Baixada Santista: $150 \mathrm{~km}$ de extensão litorânea e área de $1.887 \mathrm{~km}^{2}$.

Abrange nove municípios: Peruíbe, Itanhaém, Mongaguá, Praia Grande, São Vicente, Santos, Guarujá, Bertioga e Cubatão.

Principais características econômicas: maior porto brasileiro, complexo industrial, turismo, comércio e serviços.

Litoral Norte: $340 \mathrm{~km}$ de extensão litorânea e área de $2.474 \mathrm{~km} 2$

Abrange quatro municípios: São Sebastião, Ilhabela, Caraguatatuba e Ubatuba.

Principais características econômicas: turismo, mineração e complexo petrolífero. 
do em terra pelo divisor de águas de drenagem atlântica e no mar pela isóbata 23,6 metros, englobando todos os recursos naturais, ecossistemas terrestres e marinhos contidos nestes espaços. Para o seu planejamento deverá ser utilizado o Zoneamento Ecológico Econômico, que através de diversas análises ecológicas e socioeconômicas, estabelecidas a partir de discussões públicas e recomendações técnicas, determinará as normas de uso e ocupação do solo, aliadas ao manejo dos recursos naturais. Com participação do Estado, Município e a sociedade civil organizada, devem ser definidos os conjuntos de projetos setoriais, chamados de Plano de Ação e Gestão, compatibilizados e integrados com os parâmetros das diretrizes do Zoneamento Ecológico Econômico.

A Lei considera os quatro setores da Zona Costeira Paulista, o Litoral Norte, Baixada Santista, Complexo Estuário-Lagunar de Iguape e Vale do Ribeira, como áreas de planejamento para o gerenciamento costeiro (Figura 68).

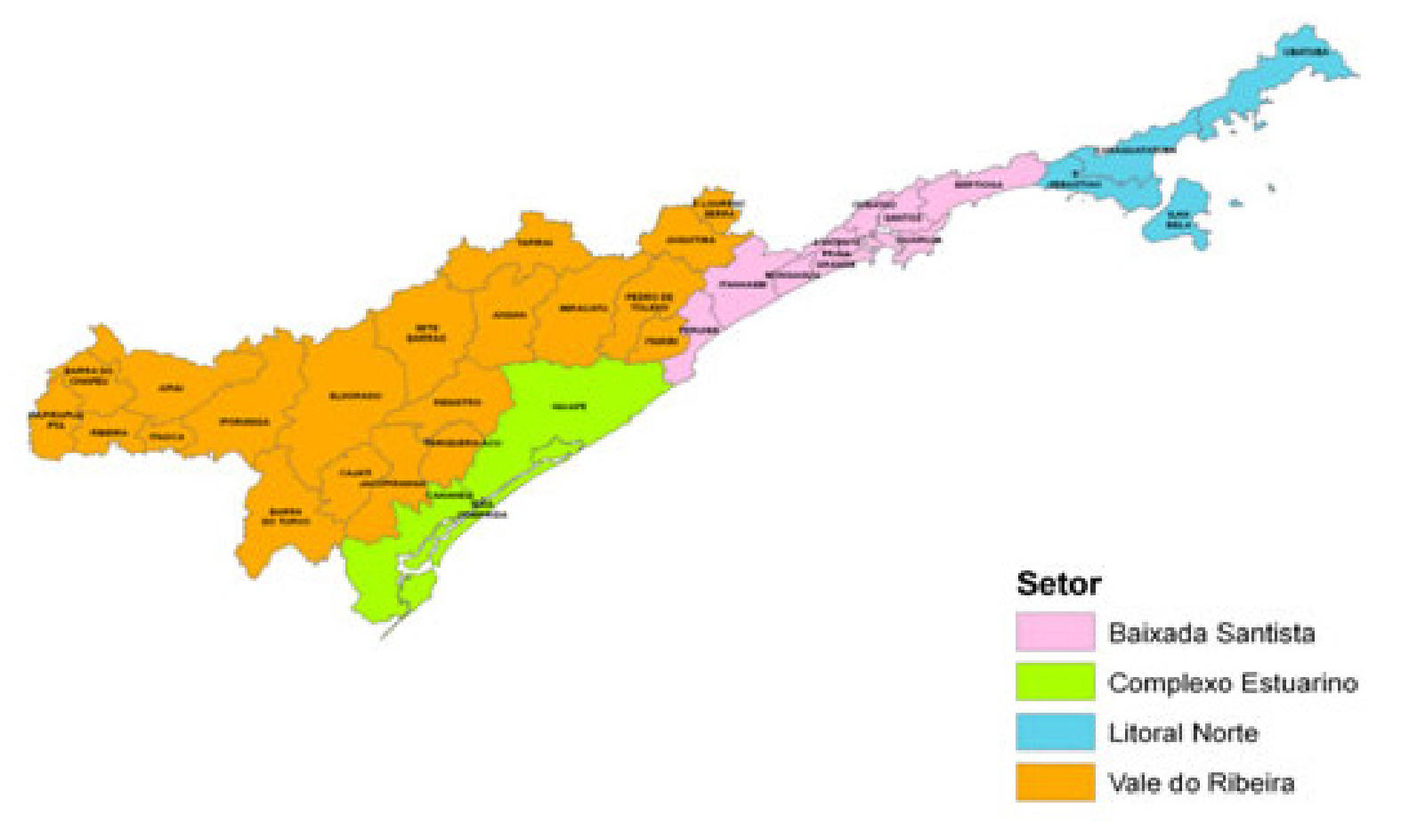

Fonte: SMA (2014).

Figura 68 - Setorização do litoral paulista

O principal objetivo é disciplinar e racionalizar a utilização dos recursos naturais, melhorar a qualidade de vida da população, principalmente a local, e garantir qualidade ambiental, com a proteção dos seus ecossistemas.

As principais metas apresentadas pelo Plano Estadual de Gerenciamento Costeiro (GERCO), estabelecidas pela Lei ${ }^{\circ} 10.019 / 88$, era compatibilizar usos e atividades humanas, controlar o uso e ocupação do solo e a exploração dos recursos naturais, além de: 
- Defender, restaurar e manter os ecossistemas representativos.

- Garantir a fixação e desenvolvimento das populações locais.

- Planejamento, gestão de forma integrada e participativa (comunidades costeiras).

- Definir o zoneamento ecológico econômico com normas e diretrizes.

- Monitorar, controlar e fiscalizar os recursos naturais.

- Implantar o Sistema de informações do Gerenciamento Costeiro.

\subsection{Macrozoneamento do Litoral Norte do Estado de São Paulo}

$\mathrm{O}$

Macrozoneamento do Litoral Norte do Estado de São Paulo foi o instrumento utilizado para iniciar os trabalhos na ordenação do território em função das diversas análises físicas, biológicas e socioeconômicas, propondo com isso usos mais adequados a cada setor do litoral. $\mathrm{O}$ objetivo era estabelecer normas e diretrizes de ocupação para promover desenvolvimento socioeconômico com a manutenção e recuperação dos ecossistemas costeiros, melhorando o padrão de vida da população de forma sustentável.

Na primeira fase do Macrozoneamento, desenvolvido entre 1989 e 1991, sob responsabilidade municipal e com participação pública, foram feitos diversos estudos e levantamentos, como o inventário ambiental, diagnósticos, prognósticos e propostas de zoneamentos, para estabelecer uma primeira base do Zoneamento Ecológico Econômico e ainda fornecer dados à elaboração dos planos diretores dos municípios.

Os estudos com as diversas características da faixa costeira entre São Sebastião, Ilhabela, Caraguatatuba e Ubatuba foram separados por temas: geologia e geotécnica, declividades, geomorfologia, cobertura vegetal, oceanografia, climatologia, uso e ocupação do solo, parcelamento do solo, infraestrutura de turismo, pesca e aquicultura. Em 1991, iniciou-se a segunda fase dos trabalhos, com atualização e complementação das informações levantadas e a digitalizações de todos os dados anteriormente coletados (SGI - Sistema de Informações Geográficas/SP).

A partir das análises e sobreposição das informações das macro infraestruturas, fluxos demográficos, fluxos turísticos, fluxos de mercadorias e objetivos desejados ao desenvolvimento econômico, levando em consideração a necessidade de preservação ambiental, chegou-se à definição de três setores funcionais para o litoral norte do estado de São Paulo: o setor de preservação e conservação, o setor turístico e ocupação da segunda residência e o setor comercial e de serviços, com ênfase aos efeitos do Porto de São Sebastião e do Terminal Petrolífero da Petrobras.

Em função de um melhor controle do gerenciamento e da capacidade de suporte ambiental, foram também definidos compartimentos de desenvolvimento, delimitados pelas microbacias hidrográficas. 
Com o cruzamento de todas as informações das características físicas, biológicas e socioeconômicas, mais a definição dos setores funcionais e dos compartimentos ambientais, o território costeiro pode ser enquadramento em cinco zonas-tipo, Z1, Z2, Z3, Z4 e Z5, regulamentadas em 1988, pela Lei ${ }^{\circ} 10.019 .{ }^{63}$

O macrozoneamento também iniciou os trabalhos de setorização no ambiente marinho, e através da sobreposição de informações retiradas das Cartas do Instituto Geográfico e Cartográfico (IGC), Cartas Náuticas da Diretoria de Hidrografia e Navegação do Mistério da Marinha e os levantamentos oceanográficos, geomorfológicos, legislação, pesca, turismo, navegação e intervençōes humanas, conseguiu definir um zoneamento marinho preliminar.

O pré-zoneamento do espaço marinho (até 6 milhas náuticas) com os estudos realizados e seguindo os mesmos critérios do zoneamento terrestre, identificou também 5 zonas para elaborar as normas e diretrizes para a sua utilização.

Ficou determinado preliminarmente que as áreas marinhas da Z1, Z2 e Z3 seriam compatíveis com atividades como a maricultura, pesca artesanal, atividades recreacionais e pequenas estruturas náuticas, e a Z4 e Z5 com a possibilidade de desenvolvimento mais amplo das atividades náuticas, sendo permitido a construção de portos comerciais, terminais hidroviários, médias e grandes estruturas de apoio à navegação de recreio.

O cruzamento de todas estas informações determinou um Zoneamento Ecológico Econômico preliminar para o Litoral Norte de São Paulo

Os estudos identificaram também quais as oportunidades de investimentos compatíveis com o desenvolvimento da costa litorânea paulista que estivessem dentro dos padrões ambientais desejados e pré-determinados pelo Macrozoneamento do litoral norte de São Paulo.

A partir da constatação de que empreendimentos imobiliários estão próximos de seu esgotamento, o novo potencial levantado seria a utilização do mar, principalmente para as atividades náuticas com foco em embarcações de recreio, o que demonstrou a necessidade de novas estruturas náuticas que ampliariam as oportunidades de desenvolvimento econômico e social para o litoral.

\footnotetext{
${ }^{63}$ O Decreto 47.303, de 8/11/2002, instituiu formalmente os Grupos de Coordenação Estadual e os Grupos Setoriais de Coordenação: Litoral Norte, Baixada Santista, Complexo Estuarino-Lagunar (Iguape e Cananéia) e Vale do Ribeira, para prosseguirem os trabalhos e estudos sobre o Plano de Gerenciamento Costeiro do Litoral Norte do Estado de São Paulo.

O Grupo Setorial de Coordenação deverá conter representantes de cada prefeitura (2), da sociedade civil organizada (2) e técnicos da Secretaria do Estado que atuem na região, e definir os Plano de Ação e Gestão de cada município e ainda elaborar as minutas necessárias.

O Grupo de Coordenação Estadual deverá ser representado por membros da Secretaria do Meio Ambiente (8), dos Municípios Costeiros (8) e sociedade civil organizada (8), para atualizar o Plano Estadual de Gerenciamento Costeiro, compatibilizando as propostas do Zonamento Ecologico Econômico com os Planos de Ação e Gestão dos Grupos Setoriais de Coordenação.

A coordenação geral será feita pela Secretaria do Meio Ambiente do Estado de São Paulo.

Fonte: Secretaria do Meio Ambiente do Estado de São Paulo, 2002.
} 
Para possibilitar o desenvolvimento social e econômico sustentável, com a manutenção e recuperação dos ecossistemas costeiros, o Macrozoneamento propôs que o setor público deveria garantir a melhoria na qualidade de vida da população local, através de ações e investimentos públicos como: saneamento básico (água, esgoto e lixo), habitação (controle da favelização), transporte e sistema viário (ênfase no potencial do transporte hidroviário), turismo ambiental (apoio ao turismo náutico), pesca (fiscalização da pesca predatória e apoio à pesca tradicional caiçara) e regulamentação do setor minerador.

\subsection{Zoneamento Ecológico Econômico - São Sebastião}

1 partir de 1988, com o Plano Nacional de Gerenciamento Costeiro (PNGC), para garantir maior Estado e Município costeiro a elaboração, com participação pública, de programas para estabelecer a melhor utilização e administração de seus recursos naturais.

Com o avanço da urbanização e o aumento populacional em direção às regiōes costeira, os planos para ordenar a ocupação destes territórios são fundamentais para compatibilizar o desenvolvimento socioeconômico, administrar os diversos interesses de uso e ainda conseguir manter a qualidade dos ecossistemas.

Os planos de gerenciamento, que tem apoio governamental e base legal, devem procurar atingir tais objetivos com a predefinição dos modelos desejados de ordenação territorial.

Priorizar a utilização das zonas costeiras com atividades compatibilizadas com suas especificidades territoriais são garantias para manter as futuras potencialidades desses territórios fronteiros à linha d'água. Por isso, os planos precisam estar dentro de processos contínuos de atualizações, de formações e informações ambientais, sempre levando em consideração a sustentabilidade dos recursos naturais. Além disso, os resultados devem ter também como finalidade proporcionar a melhoria na qualidade de vida da população.

As diferenças sociais, em conjunto com o crescimento desordenado das cidades e dos "avanços econômicos" não planejados, são os maiores responsáveis pelos problemas ambientais.

O Litoral Norte do Estado de São Paulo é um exemplo de um território costeiro que nos últimos trinta anos passou a sofrer grandes pressões urbanas, em função do crescimento dos fluxos turísticos e principalmente pelo aumento na construção da segunda residência.

Os trabalhos e estudos para gerenciar esta nova realidade foram iniciados em 1989 e depois de 15 anos, através do Decreto 49.215/04, de 7/12/2004, foi regulamentado o Zoneamento Ecológico Econômico - ZEE do Litoral Norte, ${ }^{64}$ responsável pelo levantamento das

\footnotetext{
${ }^{64}$ Decreto Estadual no 49.215/04, que dispõe sobre o Zoneamento Ecológico Econômico do Setor do Litoral Norte, prevê usos e atividades para as diferentes zonas, estabelece diretrizes, metas ambientais e socioeconômicas nos termos
} 
características físicas, biológicas, socioeconômicas e de identificar para cada setor os critérios de diferenciações tipológicas e normas disciplinadoras para ocupação do solo e manejo dos recursos naturais.

O Processo de regramento do Zoneamento Ecológico Econômico foi considerado em seu $1^{\circ}$ ciclo extremamente restritivo por diversos setores por sua visão muito conservacionista.

No $2^{\circ}$ ciclo, não estabeleceu o zoneamento regional e pretendia repassar esta atribuição aos municípios, o que também gerou grande oposição ambientalista e da sociedade civil organizada.

O $3^{\circ}$ ciclo pretendia resgatar a credibilidade no processo de implantação do gerenciamento costeiro. Uma posição intermediária, que busca atender os Planos Diretores Municipais, os interesses dos diferentes setores socioeconômicos e as demandas da população, sem contudo, descuidar-se da proteção dos recursos naturais.

O Zoneamento Ecológico Econômico dos municípios de Caraguatatuba, Ilhabela, São Sebastião e Ubatuba, engloba os ecossistemas terrestres $\left(\mathrm{Z} 1 \mathrm{~T},{ }^{65} \mathrm{Z} 1 \mathrm{AEP},{ }^{66} \mathrm{Z} 2 \mathrm{~T},{ }^{67} \mathrm{Z} 3 \mathrm{~T},{ }^{68} \mathrm{Z} 4 \mathrm{~T},{ }^{69}\right.$

estabelecidos pela Lei no 10.019 , de 3/07/1998.

Principais objetivos:

- Funçôes sociais, econômicas, culturais e ambientais inclusive das comunidades tradicionais da zona costeira, por meio de mecanismos de intervenção, regulação e estímulo a alternativas adequadas ao seu uso sustentável;

- Necessidade de promover o desenvolvimento regional sustentável através da estruturação da atividade turística, garantindo e assegurando o equilíbrio ambiental da zona costeira;

- Necessidade de promover o ordenamento territorial, através do disciplinamento dos usos e atividades de acordo com a capacidade de suporte do ambiente;

- Necessidade de promover o uso sustentável do potencial florestal, hídrico e paisagístico de forma compatível com a proteção ao meio ambiente, objetivando o efetivo desenvolvimento socioeconômico;

- Necessidade de disciplinar as formas e os métodos de manejo dos organismos aquáticos, bem como o ordenamento dos procedimentos das atividades de pesca e aquicultura, resguardando-se aspectos sócio-econômico-culturais relativos à pesca artesanal.

Disponível em: <http://www.saosebastiao.sp.gov.br/finaltemp/posturas/obras/estadual/Decreto49215_2004.pdf>. Acesso em: 07/09/2014.

${ }^{65} \mathrm{Z} 1 \mathrm{~T}$ - Áreas contínuas de vegetação em estágio avançado de regeneração e fauna associada, com alteração de cerca de $10 \%$ da cobertura vegetal e restriçōes do Dec. Fed. 750/93. Áreas com declividade média acima de 47\%, com restriçōes da Lei Fed. 4.771/65 e Resolução Conama 303/02. Existência de comunidades tradicionais. Unidades de Conservação de Proteção Integral Manguezais, com restriçōes da Lei Fed. 4.771/65 e Conama 303/02.

${ }^{66}$ Z1AEP (Zona Área Especialmente Protegida) - Parque Nacional da Serra da Bocaina, Parque Estadual da Serra do Mar, Parque Estadual da Ilha Anchieta, Parque Estadual de Ilhabela, Estação Ecológica Marinha Tupinambás, Área sob Proteção Especial CEBIMar, Área sob Proteção Especial do Costão do Navio e Área sob Proteção Especial de Boissucanga.

${ }^{67}$ Z2T (Zona 2 Terrestre) - Elevada recorrência de áreas de preservação permanente, com restriçôes da Lei Federal 4.771/65, e de risco geotécnico. Áreas contínuas de vegetação em estágio avançado de regeneração e fauna associada, com ocorrências de supressão ou de alteração de até $30 \%$ da cobertura vegetal, com restriçôes do Dec. Fed. 750/93. Ocorrência de áreas com declividade média entre 30\% e 47\%. Áreas sujeitas à inundação.

${ }^{68} \mathrm{Z} 3 \mathrm{~T}$ (Zona 3 Terrestre) - Áreas contínuas com atividades agropecuárias e assentamentos rurais e ecossistemas primitivos alterados em até 50\%. Áreas com declividade média inferior a 30\%, cobertas com vegetação secundária em estágio inicial ou médio de regeneração, com restrições do Dec. Fed. 750/93. Solos com aptidão ao uso agropecuário.

${ }^{69}$ Z4T (Zona 4 Terrestre) - Cobertura vegetal alterada ou suprimida até 70\% da área assentamentos dispersos com uso 
$\mathrm{Z} 4 \mathrm{OD},{ }^{70}$ e $\mathrm{Z} \mathrm{T}^{71}$ ) que vai do mais restritivo $\mathrm{Z} 1 \mathrm{~T}$ ao menos restritivo $\mathrm{Z} 5 \mathrm{~T}$, relacionados com metas mínimas de conservação ou recuperação que considera $90 \%$ da zona de cobertura vegetal nativa com garantia da diversidade biológica das espécies na Z1T, formação de corredores entre remanescentes de vegetação na Z3T, até nenhuma exigência de preservação na Z5T.

Os usos e atividades para o zoneamento terrestre mais restritivo estão presentes na Z1T, que admite pesquisa científica relacionada à preservação, conservação e recuperação ambiental e ao manejo autossustentado das espécies da fauna e flora regional, bem como educação ambiental, manejo autossustentado condicionado à existência de Plano de Manejo, empreendimentos de ecoturismo com finalidade e padrões que não alterem as características ambientais da zona pesca artesanal e ocupação humana de baixos efeitos impactante.

Os usos e atividades menos restritivos estão situados na Z5T, que além de admitir todos os anteriores estabelecidos, ainda permite unidades industriais, terminais aeroviários e rodoviários, complexos portuários, pesqueiros e turísticos.

Nos ecossistemas marinhos (Z1M, ${ }^{72} \mathrm{Z} 2 \mathrm{M},{ }^{73} \mathrm{Z} 2 \mathrm{ME},{ }^{74} \mathrm{Z} 3 \mathrm{M},{ }^{75} \mathrm{Z} 4 \mathrm{M},{ }^{76}$ e $\left.\mathrm{Z} \mathrm{M}^{77}\right)$ o principal objetivo destacado pelo ZEE para as Z1M e Z2M é a manutenção e melhoria da qualidade das águas costeiras, além de manter e garantir a funcionalidade dos ecossistemas, com o objetivo de assegurar a conservação da diversidade biológica, do patrimônio histórico, paisagístico, cultural e arqueológico. Segundo o zoneamento, os principais usos permitidos são pesquisa científica e edu-

urbano, e infraestrutura incompleta e relevo com declividade média igual ou inferior a $30 \%$.

${ }^{70}$ Z4OD (Zona 4 Ocupação Dirigida) - Existência de cobertura vegetal nativa. Presença de empreendimentos residenciais parcialmente implantados e/ou ocupados.

${ }^{71}$ Z5T (Zona 5 Terrestre) - Cobertura vegetal alterada ou suprimida em área igual ou superior a 70\% do total da zona. Assentamentos urbanos consolidados ou em fase de consolidação e adensamento. Existência de infraestrutura urbana, instalaçôes industriais, comerciais e de serviços.

72 Z1M (Zona 1 Marinha) - Estrutura abiótica preservada. Comunidade biológica preservada. Ausência de atividades antrópicas que ameacem o equilíbrio ecológico. Usos não intensivos, especialmente associados ao turismo e extrativismo de subsistência. Existência de áreas de reprodução de organismos marinhos.

${ }^{73}$ Z2M (Zona 2 Marinha) - Estrutura abiótica alterada por atividades antrópicas. Comunidade biológica em bom estado mas com perturbações estruturais e funcionais localizadas. Existência de atividades de aquicultura de baixo impacto ambiental. Ocorrência de atividades de recreação de contato primário.

${ }^{74}$ Z2ME (Zona 2 Marinha Especial) - Estrutura abiótica preservada. Comunidade biológica preservada. Ausência de atividades antrópicas que ameacem o equilíbrio ecológico. Usos não intensivos, especialmente associados ao turismo e extrativismo de subsistência. Existência de áreas de reprodução de organismos marinhos.

${ }^{75}$ Z3M (Zona 3 Marinha) - Estrutura abiótica significativamente alterada por atividades antrópicas. Comunidade biológica em estado regular de equilíbrio com claros sinais de perturbações estruturais e funcionais. Existência de estruturas náuticas Classe III.

${ }^{76}$ Z4M (Zona 4 Marinha) - Estruturas abióticas extremamente alteradas resultante de atividades antrópicas. Comunidade biológica, com perturbação do equilíbrio, alteração estrutural das populações ou empobrecimento da biodiversidade. Existência de estruturas náuticas Classe IV e V.

77 Z5M (Zona 5 Marinha) - Estruturas abióticas significativamente alteradas. Comunidade biológica com perturbação do equilíbrio, desestruturação das populaçôes e desaparecimento de espécies. Existência de atividades portuárias. 
cação ambiental relacionadas à conservação da biodiversidade, manejo autossustentado de recursos marinhos, pesca artesanal, ecoturismo e estruturas náuticas Classe I e Classe II.

Para as Z3M, Z4M e Z5M as diretrizes são a recuperação da qualidade ambiental e garantia da sustentabilidade ambiental das atividades socioeconômicas, além de promover o manejo adequado dos recursos marinhos. Segundo o zoneamento os principais usos para Z3M, além dos permitidos nas zonas anteriores, são as estruturas náuticas Classe III, pesca industrial e despejos de efluentes previamente submetidos a tratamento secundário. $\mathrm{Na} Z 4 \mathrm{M}$ são permitidas estruturas náuticas Classe IV e V, além dos usos das zonas anteriores, e na Z5M são permitidos todos os anteriores e mais a construção de portos e lançamento de efluentes industriais, atendidos os padrões de emissão.

Os usos permitidos vão desde pesquisa científica e educação ambiental relacionadas à conservação da biodiversidade na Z1M, até a possibilidade de construção de portos e lançamento de efluente industriais na Z5M.

O desafio da atual regulamentação do Plano de Gerenciamento Costeiro está justamente em conseguir compatibilizar os interesses econômicos através dos Zoneamentos Terrestres e Zoneamentos Marinhos (Figura 69), procurando estabelecer uma interface adequada, permeável e equilibrada entre os dois territórios, definindo locais de menor impacto ambiental e maior benefício urbano para a instalação das novas estruturas litorâneas, inclusive as de apoio e segurança à navegação, e assim atingir o real objetivo de proporcionar benefícios sociais e econômicos com equilíbrio ambiental.

A lei recomenda a possibilidade de revisão periódicas do ZEE para possíveis correções, o que é entendido por parte do setor privado como oportunidade de maior flexibilização e pressão sobe o setor público.

Em 2011, o governo autorizou o início dos trabalhos para reavaliar um ZEE de 2004 ainda não implantado, ou seja, propostas que nem viraram ações já estão sendo revisadas, o que demostra fortes indícios de que tanto o poder público quanto o setor privado pretendem tornar menos restritivo o atual ZEE. Um exemplo é o desejo de ampliar nas áreas ZT4 e ZT5, dos atuais 60\% para 80\% da taxa de ocupação e redução dos atuais lotes mínimos de $250 \mathrm{~m}^{2}$ para $125 \mathrm{~m}^{2}$.

É evidente que falta uma discussão mais ampla, principalmente com a inclusão da sociedade civil organizada, bem como estudos científicos mais responsáveis e independentes para apontar os reais impactos desta opção de ordenamento territorial a curto e médio prazo na região.

As diferenças sociais, em conjunto com o crescimento desordenado das cidades e dos "avanços econômicos" não planejados, podem ser os maiores responsáveis pelos problemas ambientais. 


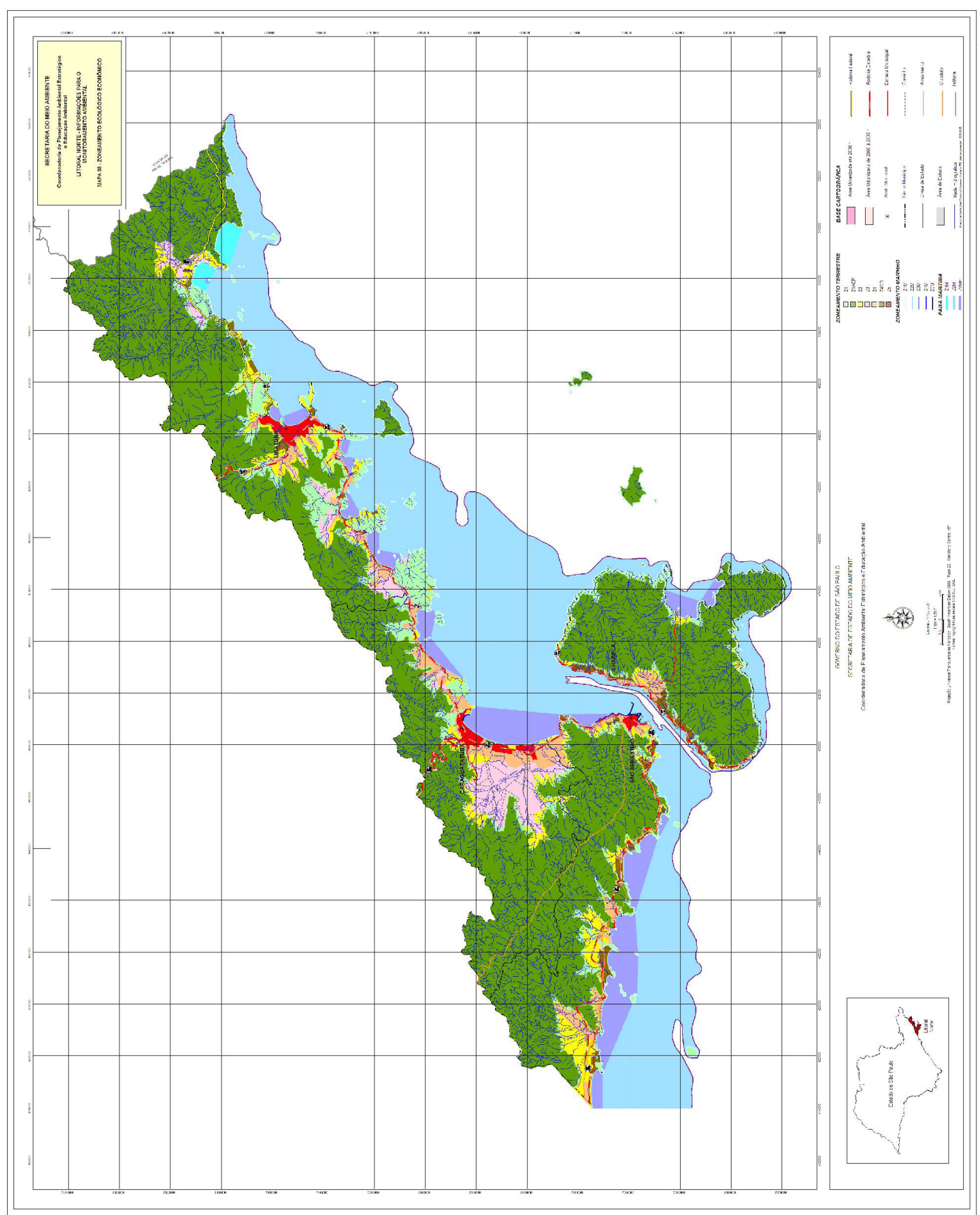

Fonte: SMA (2014).

Figura 69 - Zoneamento

Ecológico Econômico do Litoral Norte

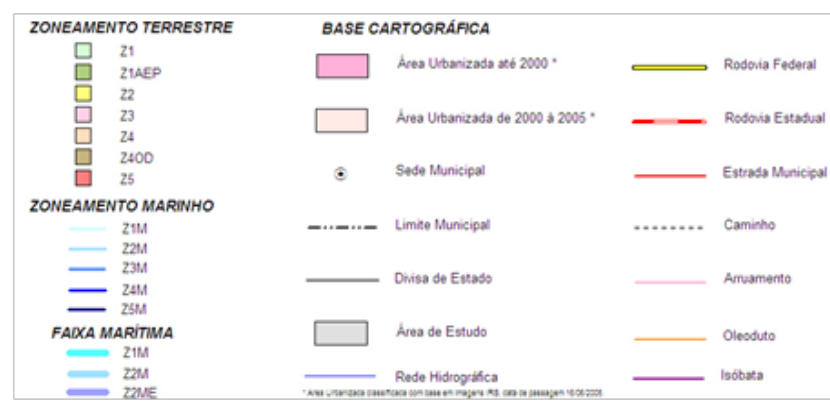


Projeto de significativo impacto ambiental

São Sebastião - São Paulo/SP 


\section{PROJETOS DE GRANDE IMPACTO AMBIENTAL EM SÃO SEBASTIÃO}

$\mathrm{O}$ presente capítulo apresenta uma síntese dos diversos estudos de impacto ambiental com significativo potencial de degradação ou poluição elaborados para São Sebastião e região, com o objetivo de demonstrar que a preocupação maior é afirmar que o empreendimento em questão traz muito mais benefícios positivos que negativos, o que não poderia ser diferente, já que tais estudos são de responsabilidade dos próprios interessados e sua conclusão deve ser positiva para garantir as licenças ambientais e viabilizar a implantação de seus empreendimentos.

Fica também evidente que não existem grandes preocupações com o efeito cumulativo dos empreendimentos com potencial poluidor, implantados ou em processo de licenciamento, na região.

Por mais que cada estudo de impacto ambiental afirme que está levando em conta as especificidades do lugar e preocupação regional, devemos discutir se de fato o território comporta a soma dos diversos empreendimentos previstos para o litoral norte de São Paulo, como a ampliação do Píer Petroleiro Terminal Aquaviário de São Sebastião, a duplicação da rodovia dos Tamoios - Trecho Planalto, nova rodovia Caraguatatuba/São Sebastião - Contorno Sul e Norte, exploração da camada pré-sal, Unidade de Tratamento de Gás Monteiro Lobato (UTGCA) - Caraguatatuba e a ampliação do porto comercial de São Sebastião.

\subsection{Ampliação do Píer Petroleiro Terminal Aquaviário de São Sebastião}

$\mathrm{O}$ atual Píer Petroleiro Terminal Aquaviário de São Sebastião (TASSE) foi inaugurado em 1969 e abastece as seguintes refinarias do Estado de São Paulo: Paulínia (REPLAN), Vale do Paraíba (REVAP), Presidente Bernardes (RPBC) e Capuava (RECAP), conforme Figura 70.

Escoa derivados do petróleo (diesel, nafta, gasolina e querosene de aviação) para outras regiôes do país e para o exterior, em torno de 135 mil metros cúbicos de petróleo e 20 mil de derivados, e tem capacidade de armazenamento para sete dias do consumo nacional.

O objetivo deste projeto, com a construção de um novo píer em concreto armado, acomodando mais 2 berços de atracação (Sul P5 e Norte P6), além da construção de uma ponte de acesso, é ampliar a capacidade para descarregar petróleo nacional e internacional. 


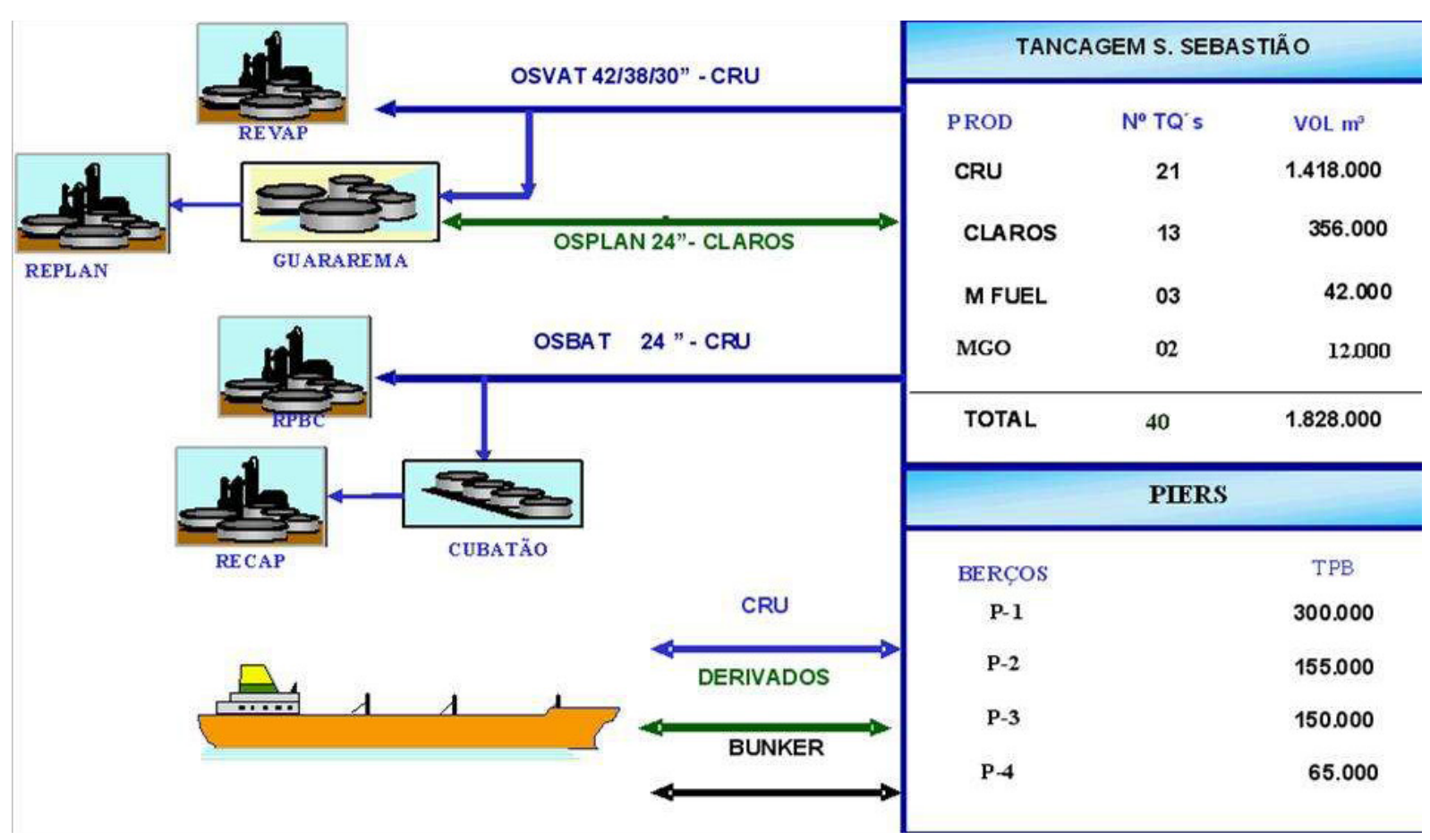

Fonte: Relatório Ambiental Preliminar da ampliação do Píer Petroleiro Terminal Aquaviário de São Sebastião.

Figura 70 - Transferência de petróleo entre os píeres do TEBAR e as refinarias de São Paulo

O Relatório Ambiental Preliminar elaborado pela empresa BOURSCHEID Engenharia e Meio ambiente justifica a ampliação das estruturas já existentes do píer atual, bem como a criação de dois novos Berços de Atracação, considerando que as instalações existentes de conexão e áreas do terminal não serão ampliadas. Este píer já é o maior terminal da TRANSPETRO do Brasil e da América do Sul. Recebe 57 navios petroleiros por mês, com movimentação de $130 \mathrm{mil} \mathrm{m}^{3} /$ dia de petróleo e, segundo a Petrobras, tem importância estratégica para o país em função das características geográficas do Canal de São Sebastião, proximidade tanto dos campos de petróleo da Bacia de Campos quanto da principal produtora e consumidora nacional de derivados de petróleo, que é o Estado de São Paulo.

O objetivo apresentado para justificar a necessidade da ampliação foi a de otimizar a infraestrutura de recebimento e transferência de petróleo para refinarias de Paulínia (REPLAN), Vale do Paraíba (REVAP), Presidente Bernardes (RPBC) e Capuava (RECAP), aumentar a disponibilidade para possíveis manutençôes e reduzir o tempo médio de estadia dos navios de 81 para 66 horas.

O Canal de São Sebastião, localizado no Litoral Norte do Estado São Paulo, costa sudeste do Brasil, entre as latitudes $23^{\circ} 42^{\prime}$ e $23^{\circ} 54^{\prime} \mathrm{S}$ e as longitudes $45^{\circ} 19^{\prime}$ e $45^{\circ} 30^{\prime} \mathrm{W}$, entre os municípios de São Sebastiāo e a Ilhabela, possui características naturais com vantagens à navegação e com potencial natural para fundeio e manobras de navios de grande calado. $O$ estudo considerou vantagens do Canal de São Sebastião para justificar a implantação da nova infraestrutura, como seu canal de navegação com profundidades maiores que $20 \mathrm{~m}$, paredes laterais abruptas, sem necessidade de dragagem e com profundidades de $50 \mathrm{~m}$ na região central do canal. 
O RAP evidencia que o município de São Sebastião, Bertioga, Caraguatatuba e Ilhabela dependem socialmente das atividades portuárias, dos benefícios econômicos, principalmente dos royalties resultado da movimentação de petróleo nacional no Terminal Aquaviário de São Sebastião - TASSE. Ao mesmo tempo define que os atuais royalties distribuídos a estes municípios não vão aumentar no futuro próximo em função desta ampliação. Afirma que atualmente estes recursos já são de grande valor e de significativo impacto positivo no meio socioeconômico da região, o que no mínimo é questionável já que o volume de petróleo aumentará, assim como os riscos ambientais.

$\mathrm{O}$ estudo também utiliza como argumento a existência de infraestrutura portuária instalada, com isto, a área já está impactada por estas atividades. Defende também que toda melhoria tecnológica e de processo que tenha como objetivo aprimorar as condiçóes operacionais de segurança no TASSE são benéficas ao município de São Sebastião, já que estas instalações são vizinhas à área urbana.

Isto deveria ser uma obrigação e não uma proposta a ser desenvolvida independentemente da ampliação, já que as instalações já existem.

O que se pretende é aumentar o fluxo de embarque e desembarque de petróleo e isto significa maiores riscos, ou seja, maior quantidade de produto circulando e contratos maiores para o empreendedor, e evidentemente novo cálculo dos royalties.

Além destas considerações deve ser ressaltado o fato de que o município de São Sebastiāo, bem
como os municípios de Bertioga, Caraguatatuba e Ilhabela, dependem socialmente da ativida-
de portuária, em função, entre outros benefícios econômicos, daquele referente ao recebimento
de royalties pela movimentação de petróleo nacional no TASSE (ANP, 2011). Muito embora
os valores destes royalties não devam aumentar no futuro próximo em função da ampliação,
deve ser ressaltado que atualmente estes já são de grande valor e de significativo impacto po-
sitivo no meio socioeconômico. Toda melhoria tecnológica e de processo que vise melhorar as
condiçóes operacionais de segurança no TASSE são potencialmente benéficas ao município de
São Sebastiāo vez que as instalaçóes do Terminal são vizinhas à área urbana deste. (Fonte:
RAP - Relatório Ambiental Preliminar Ampliação do Píer Petroleiro Terminal Aquaviário
de São Sebastião. Página 8 Cap.2. Justificativa. Data: 15-09-2011.)

Os royalties do petróleo são recursos financeiros provenientes da compensação financeira paga aos Estados e municípios pela exploração de petróleo ou gás natural em depósitos localizados na plataforma continental brasileira. Muito embora não seja esperado de imediato um aumento real no pagamento de compensaçôes financeiras pela ampliação do Píer, deve ser considerado que aumenta a confiabilidade da produção e do efetivo recebimento de petróleo nas quantidades planejadas mensalmente é fator de sustentabilidade e indutor de um maior crescimento sustentável. Neste sentido que se considerar a expectativa de que a presente ampliação em segurança e operacionalidade sirva no futuro próximo para viabilizar o aumento da capacidade produtiva do TASSE relativo ás demandas de logística do mercado de petróleo em geral, e proveniente do pré-sal inclusive. (Fonte: RAP - Relatório Ambiental Preliminar Ampliação do Píer Petroleiro Terminal Aquaviário de São Sebastião. Página 95 de 109. Data: 15-092011 Cap.6. AIA.)

O EIA-RIMA apresentou alternativas locacionais para a ampliação do Píer de São Sebastião, com o objetivo de aumentar o fluxo de petróleo em píeres interligados aos tanques do TASSE. 
Foram estudadas três alternativas ${ }^{78}$ baseadas na segurança da população e do meio ambiente, além de critérios $^{79}$ para definir a melhor solução, como a extensão do empreendimento, interferência em unidades de conservação (UC) e áreas naturais tombadas, pontos notáveis interceptados, intervenção em áreas de preservação permanente (APP), interferência em áreas construídas, interferência no trânsito das embarcações no Canal de São Sebastião e interferência nos aspectos paisagísticos (Figura 71).

Em função dos critérios acima descritos, o EIA-RIMA descartou a Alternativa 1 por considerar que apresenta maior interferência com as embarcações pesqueiras da região da Enseada do Araçá e com o trânsito da barra sul do Canal, além de possuir interferência direta na APA Marinha de São Sebastião (APA - Alcatrazes), na APP do manguezal do Araçá e do córrego Mãe Isabel. Conclui que a interferência na paisagem apresentou uma importante desvantagem nesta alternativa.

A Alternativa 2 também foi descartada pelo grande impacto na paisagem da Laje dos Moleques. É considerado um local naturalmente tombado e ainda um lugar ambientalmente não afetado.

${ }^{78}$ Alternativa 1 - Enseada do Araçá

- Píer com extensão estimada de 2,08 km, com um berço para cada braço de atracação.

- Tubovia dentro das instalações da futura ampliação do Porto da Companhia Docas de São Sebastião (CDSS) nas proximidades da Ponta do Araçá, atravessando a SP-055, o córrego Mãe Izabel e chegando ao TASSE.

Alternativa 2- Lage dos Moleques e Praia Preta

- $\quad$ Píer de $770 \mathrm{~m}$ de extensão, com dois braços de atracação.

- Ponte de acesso ao continente através de uma encosta na Praia Preta.

- Tubovia em túnel de 1750 m de extensão, contornando o bairro Topolândia, alcançando a ligação com os tanques do TASSE através de um trecho subterrâneo.

Alternativa 3 - Ampliação do píer existente

- Junto ao píer já existente do TASSE.

- Ponte de acesso dependente da estrutura do píer existente, contendo dois braços de atracação, com um berço cada.

- Nova ponte de acesso $(1,7 \mathrm{~km})$ ligando o segundo nó da atual ponte compartilhando a tubovia até os tanques do TASSE.

- Nova tubovia implantada a partir do nó de ligação até os píeres de atração dos navios.

${ }^{79}$ Critério para definir a melhor alternativa:

- Maior extensão de traçado representa maior potencial de interferências e impactos.

- Interferência em unidades de conservação (UC) e áreas naturais tombadas - impactos negativos na conservação dos recursos naturais.

- Pontos notáveis interceptados: interceptação de rodovias e córregos, por exemplo, podem resultar em construções especiais e/ou soluçôes que afetam a rotina das comunidades.

- Intervenção em áreas de preservação permanente (APP) - permitida sob autorização legal, já que estas estão protegidas pela Lei Federal no 4.771/65 (alterada pela Lei Federal no 7.803/89). Quanto maior a intervenção do empreendimento em APP, maior será o potencial de impactos em áreas consideradas de grande importância ecológica.

- Interferência em áreas construídas - implantação do empreendimento em área com adensamentos urbanos corresponde a um maior transtorno aos moradores e necessidade de desapropriações e de remoções de estruturas existentes.

- Interferência no trânsito das embarcaçôes no Canal de São Sebastião - canal intensamente utilizado por diversas embarcaçōes para atividades turísticas, econômicas, de transporte e lazer: desde canoas até grandes navios cargueiros e cruzeiros. $\mathrm{O}$ estudo entende que maior interferência no trânsito e nas atividades do Canal consistiriam em aspectos ambientais negativos importantes.

- Interferência nos aspectos paisagísticos - degradação da beleza cênica e perda de qualidade de vida da população, bem como prejudicar as atividades turísticas e de lazer. 
Além de interferir em trecho da APA Marinha do Litoral Norte (núcleo Ypautiba), APA Marinha de São Sebastião (APA - Alcatrazes), além da APP do córrego Mãe Isabel e da área natural tombada da Serra do Mar, sem considerar as construções especiais, com trecho em túnel, e interceptação de seis pontos notáveis.

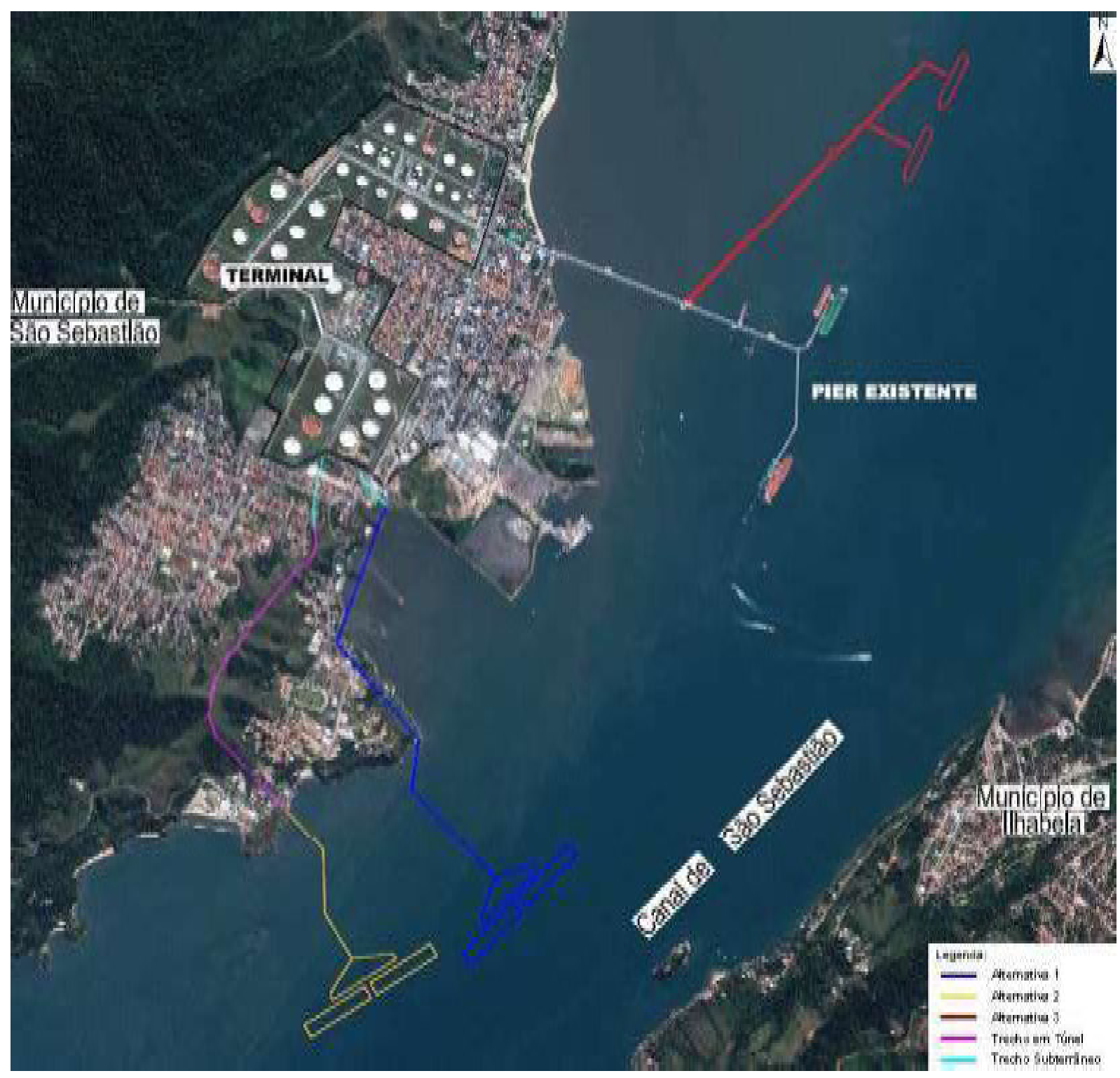

Fonte: Relatório Ambiental Preliminar de ampliação do Píer Petroleiro Terminal Aquaviário de São Sebastião.

Figura 71 - Ilustração das alternativas locacionais das propostas para o novo píer do Terminal de São Sebastião 
A Alternativa $3^{80}$ foi a escolhida apesar das desvantagens consideradas pelo relatório de alteração da paisagem e interferências no trânsito de pequenas embarcações e proximidade da APA Marinha de São Sebastião (APA - Alcatrazes) e uma unidade de conservação de uso sustentável (Figura 72).

Considerou também como vantagens a não necessidade de desapropriações e realocação de estruturas, com a utilização do píer existente e já utilizado pelos petroleiros.

O RAP conclui que a partir da excelência operacional, as futuras atividades do Terminal de São Sebastião após sua ampliação trarão muitos benefícios econômico e não oferece impactos negativos significativos.

O que podemos observar neste relatório é a grande preocupação com a interferência na paisagem e na APP da Baia do Araçá e seu manguezal, considerado um setor naturalmente tombado, protegido e ambientalmente não afetado. A existência de embarcações pesqueiras da região e o trânsito da barra sul do Canal também são considerados aspectos negativos, além de possuir interferência direta na APA Marinha de São Sebastião.

Mais adiante analisaremos neste trabalho o EIA-RIMA da ampliação do porto de São Sebastião e poderemos verificar que os critérios utilizado para descartar as alternativas 1 e 2 do Manguezal do Araçá, para a ampliação do píer da Petrobras, serão justamente os elementos que o outro EIA-RIMA dará menos ênfase, desqualificando sua importância, e concluirá, como veremos, que é possível utilizar a Baia do Araçá, em nome do benefício econômico e social da região, para construção do retroporto, única alternativa locacional, apesar das duas soluçōes técnicas apresentadas (aterro ou construção de laje sobre pilotis).

Mais uma vez constatamos indícios de que a falta de estudos cumulativos e sinergéticos entre empreendimento em processo de licenciamento simultâneos no Litoral Norte de São Paulo apresentam conclusões diferentes sobre os mesmos estudos, teoricamente científicos.

${ }^{80}$ Impacto no meio socioeconômico, segundo o estudo:

- Impactos positivos: investimentos para sua instalação e operação, arrecadação de impostos, pagamento de royalties ao Estado e Municípios, criação de novos postos de trabalho, tecnologia e conhecimentos especializados, com expectativa de efeitos reais, sinérgicos e indutores de aporte permanente de recursos humanos e financeiros inerente à complexa estrutura de aquisição de bens.

- Impacto negativo: pressão exercida sobre a população pelo aumento pontual do tráfego de veículos e máquinas durante a implantação da obra, o que poderá trazer transtornos de interaçóes sociais gerados pela necessidade de serviços e materiais de insumo às atividades do sistema (bens e serviços de manutenção e operação do sistema).

Impacto no meio físico e biótico:

- Impactos negativos: elementos poluentes apenas em casos de acidentes e emissões atmosférica. Considera que impactos negativos significativos são passíveis de mitigação e prevenção por meio dos Programas Ambientais. 


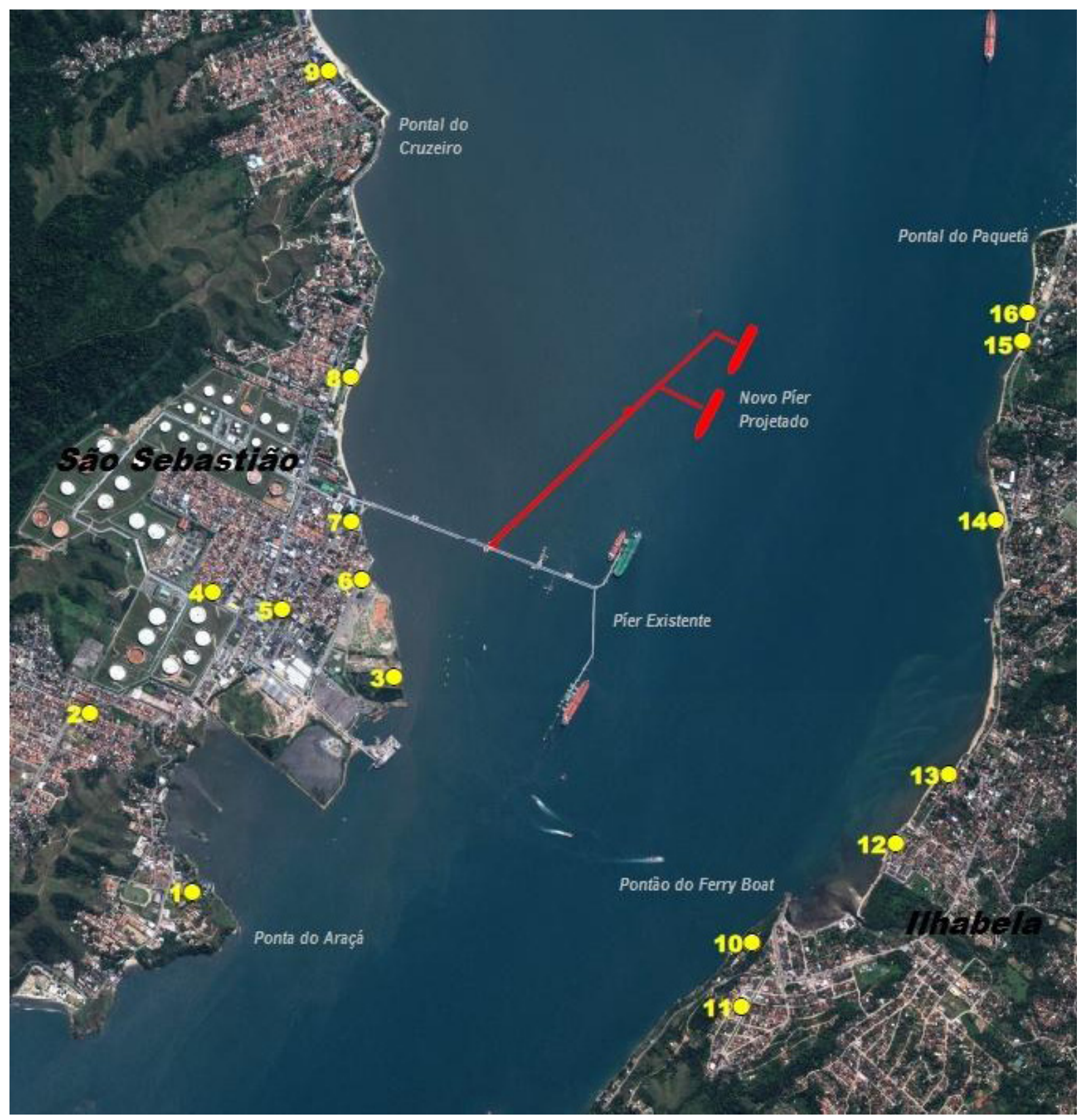

Fonte: Relatório Ambiental Preliminar Ampliação do Píer Petroleiro Terminal Aquaviário de São Sebastião.

Figura 72 - Alternativa 3 escolhida para a ampliação do Píer Petroleiro Terminal Aquaviário de São Sebastião

\subsection{Duplicação da rodovia dos Tamoios}

rodovia dos Tamoios é uma das principais vias de acesso aos municípios turísticos situados no
litoral norte do estado de São Paulo. É também a principal ligação desta região litorânea com o interior do estado, especialmente com a região do Vale do Paraíba. As empresas responsáveis pelo Estudo de Impacto Ambiental foram a JGP Consultoria e Participações Ltda. E a Ambiente Brasil Engenharia, para o trecho Planalto, Serra, Contorno Sul e Contorno Norte (Figura 73). 


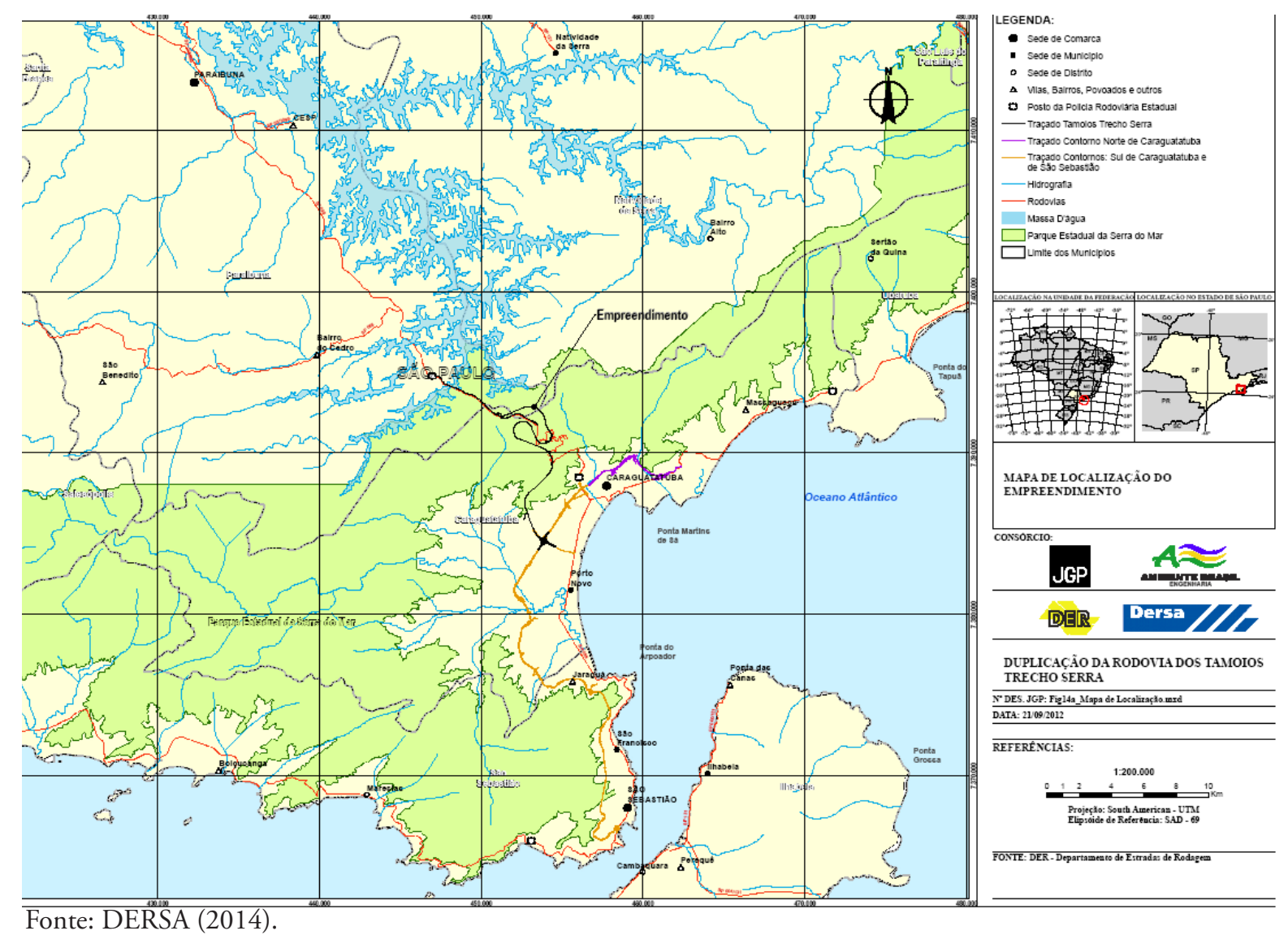

Figura 73 - Duplicação da rodovia dos Tamoios - Trecho Planalto, Serra, Contornos Sul e Norte de Caraguatatuba.

\subsection{Trecho Planalto (SP-099)} Implantação e operação da segunda pista no Subtrecho Planalto da rodovia dos Tamoios
(SP-099), entre o $\mathrm{Km} 11,5$ e o $\mathrm{Km}$ 60,48, que atravessa os municípios de São José dos Campos, Jacareí, Jambeiro e Paraibuna, foi justificada por estar próximo à capacidade máxima da via, além dos trechos com geometria desfavorável, sobretudo com curvas e rampas e alto índice de acidentes.

Através dos levantamentos, o EIA identificou e avaliou os impactos potencialmente decorrentes da implantação e operação da duplicação deste trecho, consideraram na época dos estudos que se tratava de uma regiāo já antropizada e que a nova pista seria em grande parte implantada dentro da atual faixa de domínio da rodovia dos Tamoios, mas mesmo assim exigiu a supressão de 22,9 hectares de formações nativas de porte florestal nesta faixa e ainda a ampliação ou redução dos taludes existentes.

\footnotetext{
${ }^{81}$ Foram construídos 21,5 km no trecho da Serra do Mar, 12,6 km em túneis e 2,5 km viadutos com 188 hectares impactados, onde 6 hectares em áreas preservadas da Mata Atlântica com investimento de R 2,1 bilhões.
} 
O estudo conclui que apesar dos impactos ambientais considerados reduzidos em áreas antropizadas, o impacto do empreendimento é favorável adotando as medidas mitigadoras ${ }^{82}$ e compensatórias apresentadas e que deverão gerar benefícios à população como um todo, reduzindo o risco de acidentes na rodovia e favorecendo o processo de desenvolvimento regional.

Segundo os próprios estudos do Dersa (Desenvolvimento Rodoviário S/A), a duplicação já implantada e inaugurada no ano de 2014 não resolverá o problema de congestionamentos em épocas de temporada e feriados (Figura 74).

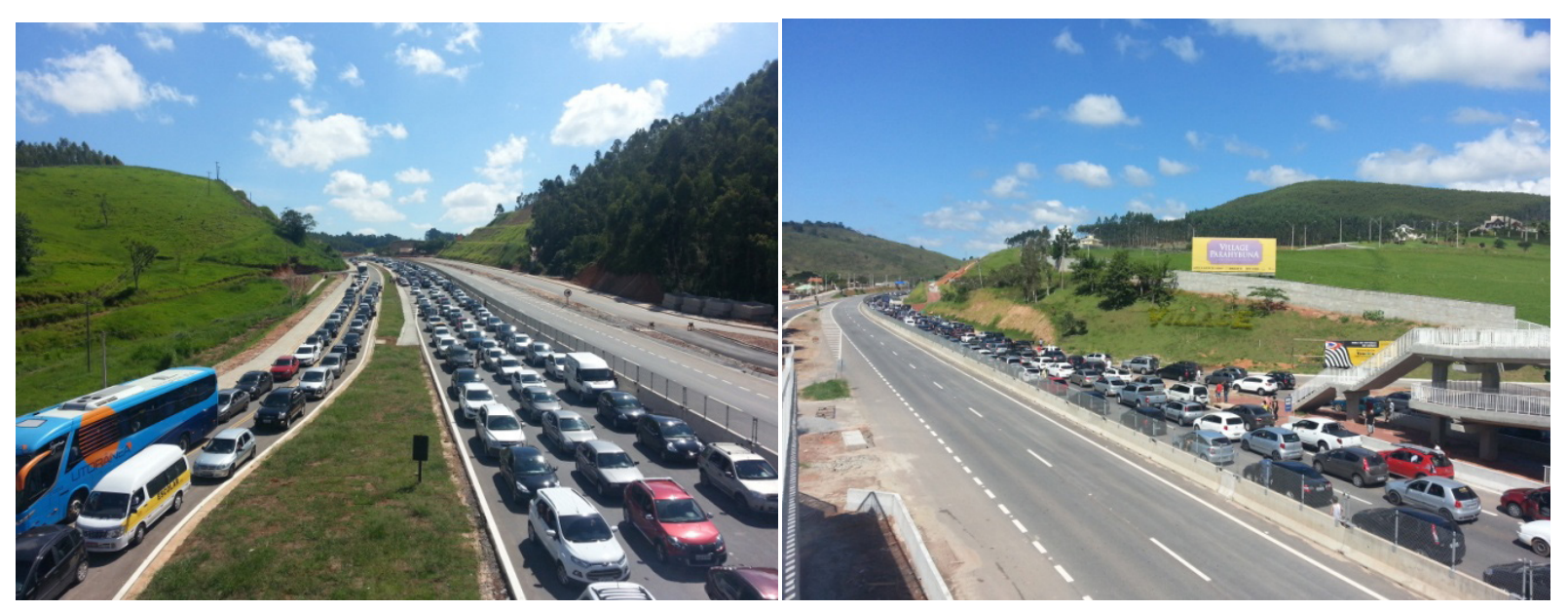

Fonte: José Francisco Xavier Magalhães (2014).

Figura 74 - Duplicação da rodovia dos Tamoios - Trecho Planalto

Congestionamento em direção ao Litoral Norte no feriado de Páscoa.

19 de Maio de 2014.

Sua vida útil é de 25 anos, mas caso o porto de São Sebastião seja de fato ampliado, o efeito desta duplicação, que custou mais de $\mathrm{R} \$ 2$ bilhões apenas no Trecho Planalto, cai para apenas dez anos.

Podemos concluir, mais uma vez, que os empreendimentos não estão sendo pensados em conjunto e de forma sinergéticas.

${ }^{82}$ Principais medidas mitigadoras apontadas pelo EIA trecho Planalto:

- Medidas mitigadoras e compensatórias para os componentes do meio biótico:

Projeto paisagístico de recomposição ambiental da faixa de domínio - plantio e recuperação.

- Medidas mitigadoras e compensatórias para os componentes do meio antrópico:

- Mais diversificados, afetando positiva ou negativamente diversos componentes ambientais.

- Receptores principais dos benefícios ou impactos positivos.

- Impactos positivos terão abrangências geográficas mais amplas.

- Impactos negativos ao longo da faixa de domínio e no entorno imediato apenas durante o período de obras (moradores e usuários).

- Relocação definitiva de imóveis - bastante limitada e deverá seguir programas de desapropriação ou reassentamento. 


\subsection{Trecho Serra - Duplicação da rodovia dos Tamoios}

$\mathrm{O}$

EIA apresentou alternativas para o traçado da rodovia que evitassem as interferências em superfície do Parque Estadual da Serra do Mar - PESM, com a utilização de túneis para transposição da Serra do Mar e ainda com a redução dos caminhos de serviço dentro da unidade de conservação, ou seja, uma nova pista com $16 \mathrm{~km}$, com percurso de 12,6 quilômetros em túnel e 2,6 quilômetros em pontes e viadutos, com a incorporação de túneis de serviço paralelos aos túneis principais, em seção menor e interligados a cada 250 metros, para atender a normas de segurança durante a futura operação.

Aponta que a duplicação será responsável pela economia nos custos de transportes e para uma grande diversidade de outros benefícios socioeconômicos diretos e indiretos. $\mathrm{O}$ estudo justifica também que o trecho serra de duplicação da rodovia dos Tamoios, por estar dentro de um contexto de crescimento econômico, poderá potencializar ainda mais esta condição com a melhoria da infraestrutura de transportes para atender as crescentes demandas da população residente e flutuante e contemplar os três eixos que sustentam a economia regional: turismo, atividades do setor de óleo e gás e atividades portuárias.

O Estudo de Impacto Ambiental afirma que a alternativa proposta para a duplicação deste trecho da SP-099 (Figura 75), adotando as medidas de mitigação, compensação e programas sugeridos, ${ }^{83}$ não constituirá uma ameaça ou risco à biodiversidade e ao equilíbrio físico-biótico da Serra do Mar por se tratar de impactos ambientais de baixa intensidade no Parque Estadual e que os benefícios positivos terão maior abrangência no meio antrópico com alcance regional, tanto para o Litoral Norte do estado de São Paulo como para o Vale do Paraíba.

Uma obra necessária segundo os estudos, apesar da supressão de 26,82 ha de floresta nativa dentro de uma unidade de conservação, mas novamente podemos verificar a falta de sinergia com

${ }^{83}$ Principais Impactos apontados pelo EIA Trecho Serra:

Meio biótico:

- Supressão de formações florestais nativas em 26,82 ha: compensado com o plantio ou regeneração de uma área equivalente a $168 \mathrm{ha}$, em locais a serem definidos. O EIA considera a médio prazo um ganho ambiental em termos de cobertura vegetal.

- Impactos na fauna silvestre com perda de habitat em função da supressão de vegetação e alteração de terrenos e avalia a potencial perda de espécies, perda de populações e perda de indivíduos e a interferência com corredores ecológicos. Proposta de instalação de quatro passagens de fauna.

Meio físico:

- Risco de contaminação do solo, dos cursos d'água ou do lençol freático em função de acidentes como vazamentos de combustíveis ou outros produtos. Plano de Ação de Emergência para este tipo de acidente.

- Impactos na qualidade do ar durante a construção serão baixos e terão a sua duração restrita ao período de obras. $\mathrm{Na}$ fase de operação, os impactos serão permanentes com os poluentes de fonte móvel.

Meio antrópico:

- Considera que os impactos positivos terão abrangências geográficas mais amplas para o Litoral Norte e Vale do Paraíba

- Considera impactos negativos pontuais e limitados nas áreas lindeiras. 
os demais projetos, principalmente com a ampliação do porto comercial de São Sebastião, que é citado no estudo como um dos três eixos que sustentam a economia regional, mas não se aprofunda no tipo de carga ${ }^{84}$ regularidade, entre outras características, para ajustar o projeto e ampliar a vida útil deste empreendimento.

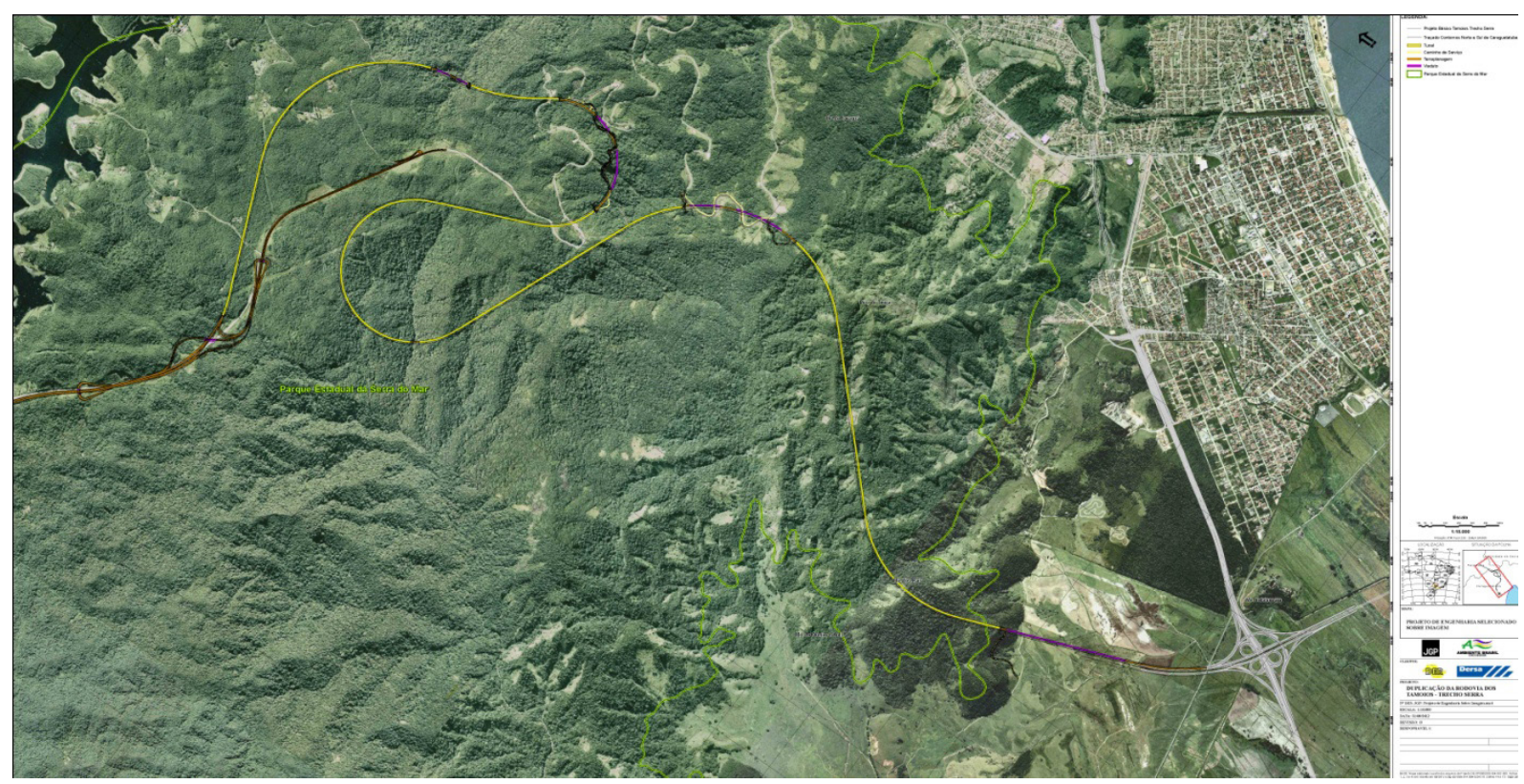

Fonte: DERSA (2014).

Figura 75 - Duplicação da rodovia dos Tamoios - Trecho Serra

\subsection{Contorno Sul - Caraguatatuba /São Sebastião}

todovia será considerada o novo acesso ao porto de São Sebastião, e ainda responsável por separar
o tráfego local do regional, reduzindo o trânsito, principalmente no município de Caraguatatuba. Estende-se desde a rodovia dos Tamoios - SP-099, no município de Caraguatatuba, até a SP-055, na altura do Porto de São Sebastião, com custo estimado de R \$ 1,6 bilhão.

Com 30,8 quilômetros de pistas novas, duas faixas de 3,6 m de largura e uma faixa de acostamento de $3 \mathrm{~m}$ por sentido, com inclinação máxima de $6 \%$. Serão 31 viadutos, 5 pontes e 4 túneis, e, para isto, será necessário o corte de 940 mil metros quadrados de Mata Atlântica, a derrubada de 938 imóveis com a desapropriação 335 hectares, sendo que 44,7\% deste valor estão localizadas no município de São Sebastião e bairro Topolândia, com o objetivo claro de conectar o Contorno Sul diretamente ao Porto de São Sebastião.

\footnotetext{
${ }^{84}$ Os tuneis projetados para duplicação da rodovia dos Tamoios podem inviabilizar o tranporte de alguns tipos de cargas, principalmente as cargas de projeto.
} 
O EIA considerou a alternativa da não implantação do Contorno Sul, mantendo a utilização da SP-055 com sua duplicação, mas como a via apresenta características de avenida urbana com capacidade de tráfego esgotada e níveis de acidentes e de serviços inadequados, foi descartada por não promover a segregação entre o tráfego local e o tráfego regional.

O estudo concluiu inviável a duplicação da SP-055, que apresenta intensa ocupação lindeira e a necessidade de separação dos fluxos de tráfego de passagem e regionais dos fluxos de tráfego locais e atender aos futuros aumentos de tráfego decorrentes dos projetos em implantação no Litoral Norte, incluindo a ampliação do Porto de São Sebastião e os investimentos de exploração de gás e petróleo.

O EIA-RIMA considera que o projeto apresentado levou em conta o melhor traçado geométrico, sistema de drenagem, configuração e o posicionamento das obras de arte especiais, métodos construtivos, custos de implantação, análise ambiental, características operacionais e avaliação geológico-geotécnica, para minimizar as interferências sobre Unidades de Conservação em trecho do PESM (Parque Estadual da Serra do Mar) e evitar, na medida do possível, as interferências com áreas de urbanização consolidada e a área natural tombada da Serra do Mar.

$\mathrm{Na}$ etapa de operação, o EIA sugere a implantação de paisagismo em toda a faixa de domínio e propõe a articulação institucional entre o DER e as prefeituras locais, com a intenção de garantir soluções adequadas para a articulação de novos empreendimentos imobiliários ou produtivos, o zoneamento municipal e a operação segura da futura rodovia.

O planejamento destes setores já deveriam fazer parte dos planos diretores das cidades, tratando o assunto de forma conjunta para que as diretrizes urbanas e de zoneamento pudessem influenciar nas decisões e não ao contrário. Mais uma vez, apenas os critérios da engenharia rodoviária determina o desenvolvimento urbano.

O estudo conclui que o Contorno Sul ${ }^{85}$ aumentará a capacidade rodoviária permitindo atender adequadamente as atuais e futuras demandas de infraestrutura de transportes regionais (Figura76).

${ }^{85}$ Principais Impactos considerados pelo EIA com a construção do Contorno Sul:

Meio físico:

- Impactos no relevo, na estabilidade das encostas nos terrenos acidentados e potencial erosão. A implantação da pista em viadutos nos trechos de topografia e terrenos mais desfavoráveis é considerado pelo estudo açóes mitigadoras destes impactos potenciais.

Meio biótico:

- Corte de $940 \mathrm{mil} \mathrm{m}^{2}$ de Mata Atlântica, apesar do EIA informar que o traçado proposto priorizou áreas antropizadas com pouca ou nenhuma cobertura de florestal nativa.

Meio antrópico:

- Considerado o maior beneficiário dos impactos positivos para grande quantidade de pessoas e atividades econômicas.

- Melhor acessibilidade de circulação regional beneficiando todos os habitantes além da população flutuante vinculada ao turismo.

- Não foram identificadas interferências diretas com o patrimônio histórico-arqueológico e que o túnel sob o sítio arqueológico em São Francisco - São Sebastião não gera nenhum tipo de conflito.

- Reduzir os impactos na qualidade ambiental dos bairros atravessados e na qualidade de vida da população lindeira às obras. 


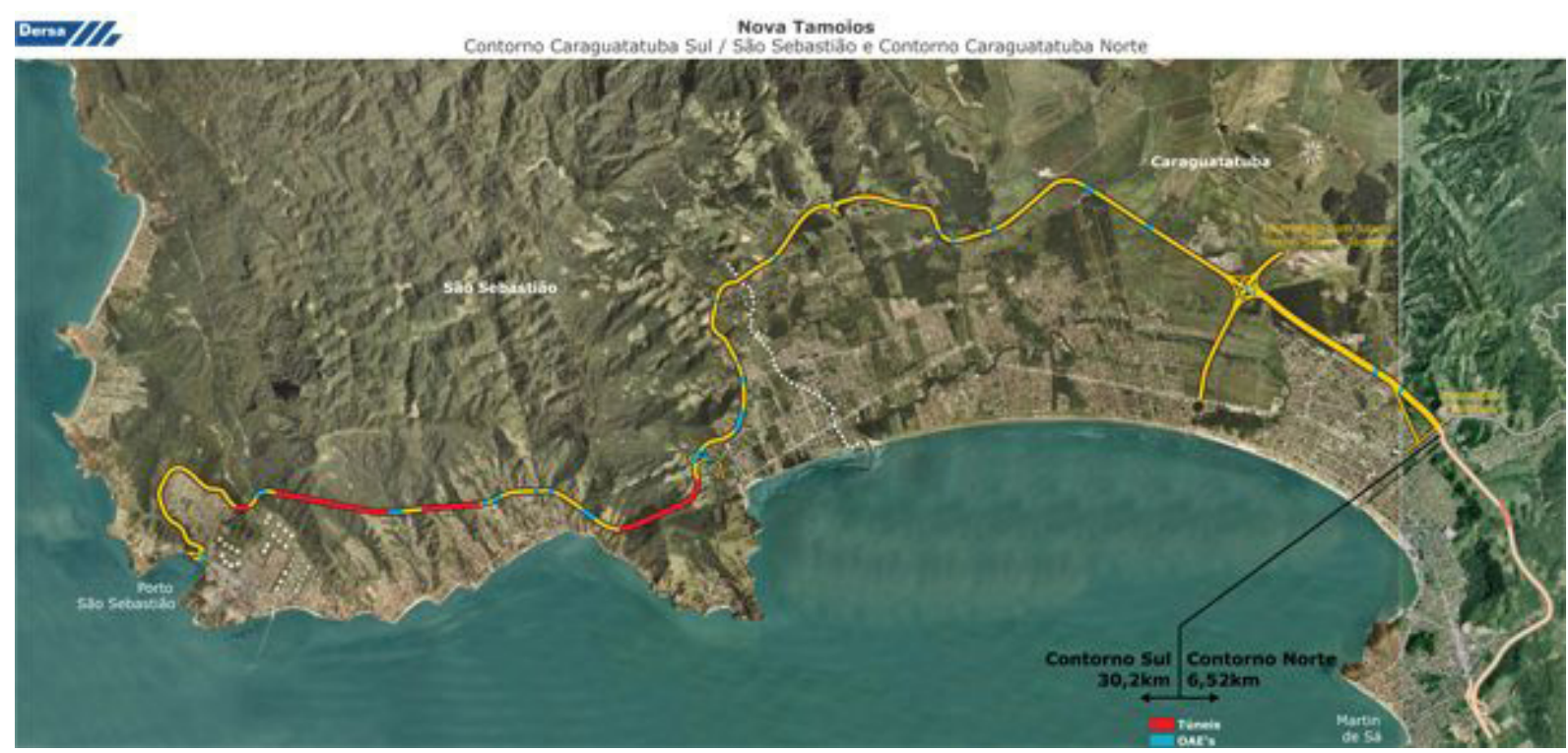

Fonte: DERSA (2014).

Figura 76 - Contornos Sul e Norte de Caraguatatuba

Conforme já mencionado anteriormente, os próprios estudos da DERSA informam que a vida útil prevista para 25 anos deste sistema de duplicação da rodovia cairá para dez anos caso o porto seja ampliado.

\subsubsection{Contorno Norte}

$\mathrm{O}$ contorno Norte interligará a rodovia dos Tamoios (SP-099) até o entroncamento com a rodovia Dr. Manoel Hypólito Rego (SP-055) em seu km 99, altura da Praia Martim de Sá, no município de Caraguatatuba. São sete quilômetros de pistas novas e um túnel de 400 metros com um custo estimado de $\mathrm{R} \$ 320$ milhões.

A alternativa apresentada tem como condicionante ambiental as delimitações de áreas; urbanizadas consolidada e semi-consolidada, fragmentos e/ou maciços florestais, unidades de conservação e outras zonas de preservação e/ou interesse ambiental estabelecidas na legislação, com análises comparativas das alternativas considerando principalmente restrições ambientais e a construção de obras de arte especiais (OAE) como pontes e viadutos rodoviários para transpor obstáculos naturais ou manter a comunicação entre os dois lados da rodovia, o que também pode ser verificado na Figura 76. 
8.6 EIA-RIMA - Projetos integrados de produção e escoamento de petróleo e gás natural no polo pré-sal - Bacia de Santos

$\mathrm{O}$ utro grande empreendimento que deve ser considerado é exploração da camada pré-sal na região. A reserva Tupi contém depósitos de óleo de alta qualidade na bacia de Santos, com previsão para produzir entre 5 e 8 bilhões de barris de petróleo e gás, um potencial para dobrar as atuais reservas brasileiras com hipótese de 50 bilhões de barris na área e plano de investimento da Petrobras de US\$ 111 bilhões até 2020 (Figura 77).

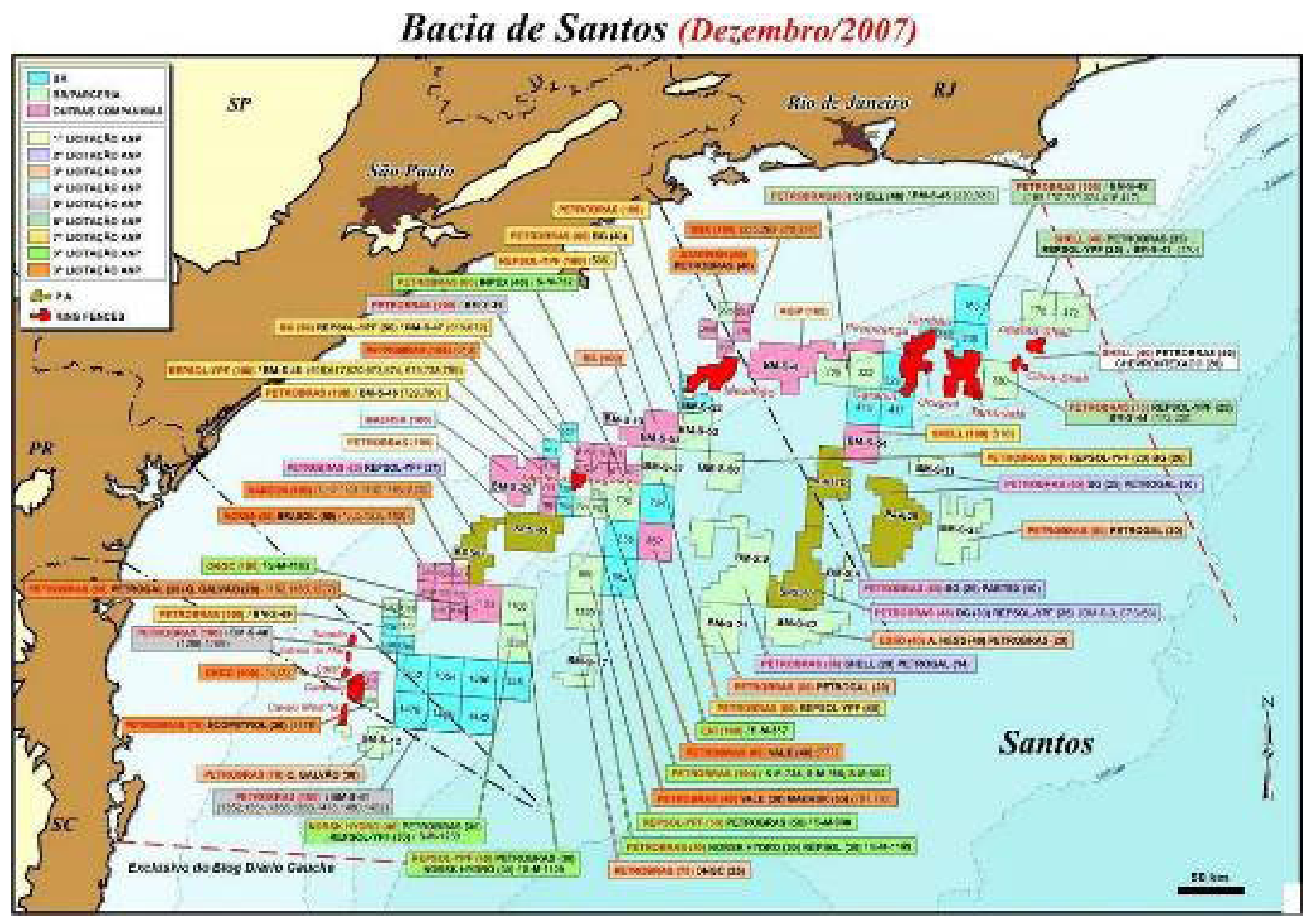

Fonte: http://www.naval.com.br/blog/tag/amazonia-azul/

Figura 77 - Bacia de Santos - camada pré-sal

A empresa responsável pelo Estudo de Impacto Ambiental dos projetos integrados de produção e escoamento de petróleo e gás natural no polo pré-Sal - Bacia de Santos foi a ICF Consultoria do Brasil, que segundo testes realizados na região, afirmam a viabilidade técnica e econômica e consideram o petróleo existente na camada pré-sal da Bacia de Santos com baixa densidade (óleo leve, baixa acidez e teor de enxofre), o que resulta em um petróleo de alta qualidade e maior valor de mercado (Figura 78).

$\mathrm{O}$ estudo indica as oportunidades para a indústria nacional e arrecadação de impostos com a exploração deste petróleo e informa que as receitas dos municípios pertencentes à área de influência dos empreendimentos também serão ampliadas devido ao recebimento de royalties e ao recolhi- 
mento de Imposto sobre Serviços, que deverão ser preferencialmente direcionados à áreas estratégicas, como: educação, combate à pobreza, ciência, tecnologia e preservação do meio ambiente.

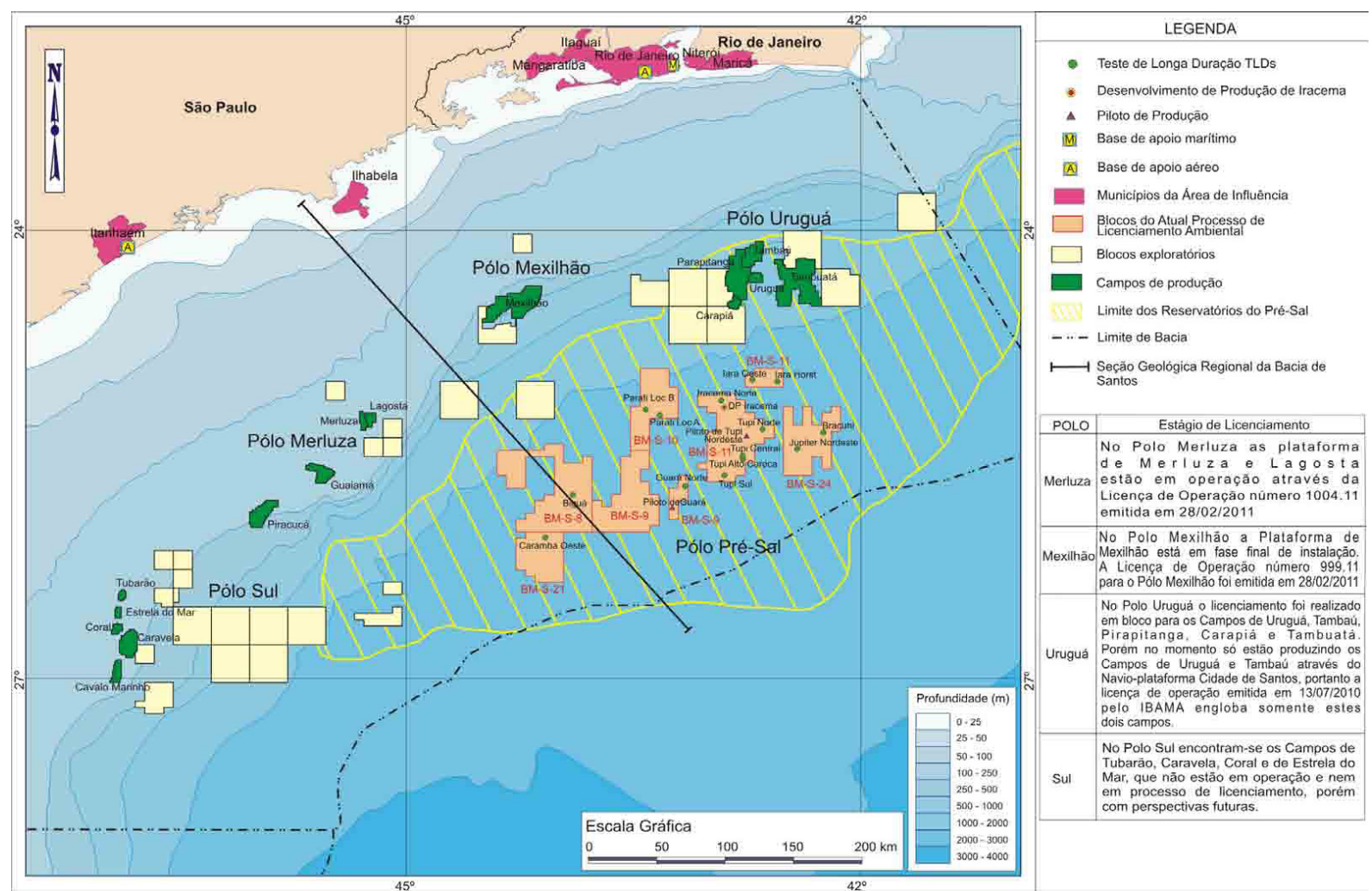

Fonte: RIMA - Projetos Integrados de Produção e Escoamento de Petróleo e Gás Natural no Polo Pré-Sal, Bacia de Santos. Petrobras (2011).

Figura 78 - Camada pré-sal da Bacia de Santos

A camada pré-sal está localizada nos blocos exploratórios distante aproximadamente $340 \mathrm{~km}$ da costa e a grandes profundidades.

Segundo o EIA a alternativa mais viável para sua exploração será a utilização de Unidade Estacionária de Produção (UEP) do tipo Floating, Production, Storage and Offloading (FPSO) com o escoamento de óleo através de navios, mas o que ainda é considerado operação de alto risco ambiental.

Os estudos apresentaram as áreas mais sujeitas aos possíveis impactos ambientais negativos. Os critérios utilizados para a definição das áreas de influência seguiram diretrizes do Termo de Referência ${ }^{86}$ o que determinou que os municípios confrontantes aos poços (Rio de Janeiro, Niterói, Mari-

${ }^{86}$ Principais diretrizes do Termo de Referência que condicionaram a definição da área de influência:

- Impactos relacionados à instalação de estruturas, considerando área de segurança, entorno das unidades e equipamentos submarinos;

- Impactos decorrentes do descarte de efluentes.

- Interferência com a atividade de pesca artesanal.

- Distribuição de royalties estabelecida pela Agência Nacional do Petróleo, Gás Natural e Biocombustíveis (ANP).

- Rotas das embarcações utilizadas durante a atividade até as bases de apoio, incluindo os próprios portos ou terminais. 
ca, Itaguaí, Mangaratiba e Ilhabela) fossem preliminarmente estimados como possíveis beneficiários do recebimento de royalties.

O Estudo de Impacto Ambiental concluiu que as atividades dos projetos integrados de produção e escoamento de petróleo e gás natural no polo pré-sal, Bacia de Santos, não deverão causar impactos significativos ao meio ambiente físico, biótico e socioeconômico, desde que sejam aplicadas as precauções necessárias à preservação ambiental, através da implementação das medidas mitigadoras.

O EIA considerou que as interferências sobre os meios físico e biótico estão restritas às áreas oceânicas, pela grande distância da costa, mas ao mesmo tempo apresenta os impactos potenciais com consequências mais graves como o derramamento acidental em grandes volumes de petróleo, de óleo e de produtos químicos no mar e que podem eventualmente atingir restingas, manguezais, estuários, costôes rochosos, praias arenosas, unidades de conservação, estoques e atividades pesqueiras, além do setor turístico.

Para situaçōes de risco potencial do empreendimento, o estudo informa que haverá medidas de contingenciamento e mitigadoras, definidos e quantificados nos planos de emergências.

O EIA não considerou os municípios de São Sebastião, ${ }^{87}$ Ubatuba $^{88}$ e Caraguatatuba dentro da área de influência, mas caso haja algum vazamento de petróleo, certamente todos estes municípios serão impactados. Não podemos compreender então quais os motivos para que o EIA não incluísse todos os municípios do Litoral Norte dentro da área de influência desde o início dos trabalhos.

Somente após grande pressão de diversas entidades e prefeitos municipais, durante uma das audiências públicas realizada no município de Ilhabela no ano de 2011, as cidades do Litoral Norte paulista, que não haviam sido contempladas nos estudos de impacto ambiental, foram incluídas na área de influência direta, com direito as futuras compensações ambientais e financeiras. ${ }^{89}$

Mais uma evidência de que os EIA devem ser aperfeiçoados para evitar desgastes desnecessários e apresentar claramente estudos científicos que informem de maneira objetiva os resultados das análises e suas possíveis consequências.

\footnotetext{
${ }^{87}$ Certamente o Porto de São Sebastião será utilizado como base de apoio.

${ }^{88} \mathrm{O}$ aeroporto de Ubatuba poderá ser utilizado como base de apoio.

${ }^{89}$ O Ibama emitiu a Licença Prévia para a atividade de produção e escoamento de petróleo e gás natural no polo pré-sal na Bacia de Santos em setembro de 2014. Com previsão de instalação de 13 novos navios-plataforma localizados aproximadamente a $300 \mathrm{~km}$ de distância da costa até o ano de 2017. A primeira destas plataformas, denominada Cidade de Ilhabela, tem previsão para entrar em operação já em 2014. Informa que deverão ser implantados novos projetos ambientais para acompanhamento e controle dos impactos do projeto sobre o meio ambiente, tais como o Projeto de Monitoramento de Cetáceos, Projeto de Monitoramento de Ruído Ambiente Submarino, Projeto de Monitoramento de Praias, Plano de Manejo de Aves nas Plataformas e o Projeto de Monitoramento do Tráfego de Embarcações. Disponível em: <http://www.ibama.gov.br/publicadas/ibama-emite-licenca-para-producao-e-escoamento-de-gas-do-polo -pre-sal-da-bacia-de-santos-sp>. Acesso em: 22/09/2014.
} 


\subsection{EIA - Unidade de Tratamento de Gás de Caraguatatuba (UTGCA)}

Unidade de Tratamento de Gás (UTGCA) ocupa uma área de $735.150 \mathrm{~m}^{2}$ no município
de Caraguatatuba. É um sistema com capacidade para processar 20 milhôes de metros cúbicos diários de gás natural e vai atender à crescente demanda por consumo doméstico, industrial, produção de energia e combustível para veículos. Recebe gás de três plataformas marítimas localizadas na Bacia de Santos, maior reserva brasileira de gás natural, produzido no Campo de Mexilhão e escoado pelo Gasoduto Caraguatatuba até a Estação de Compressão localizada no município de Taubaté.

Como é considerada atividade potencialmente poluidora e utilizadora de recursos ambientais, apesar de ser considerada uma fonte de energia mais limpa, o EIA-RIMA foi obrigatório e elaborado pela empresa BIODINÂMICA Engenharia e Meio Ambiente Ltda., contratada pela PETROBRAS - Petróleo Brasileiro S.A. para obtenção da Licença Prévia (LP) no Instituto Brasileiro de Meio Ambiente e dos Recursos Naturais Renováveis - IBAMA.

O estudo considerou inicialmente os possíveis municípios para implantação da unidade de tratamento: na Baixada Santista (Refinaria Presidente Bernardes de Cubatão), Terminal de São Sebastião, Angra dos Reis/Sepetiba e Caraguatatuba/Ubatuba, que foi a região escolhida para chegada do gás (Figura 79) e segundo o estudo apresentava melhores condições de recebimento e transporte para o mercado consumidor, através da interconexão de um ramal do gasoduto da Unidade de Tratamento de Gás até o Gasoduto Campinas - Rio de Janeiro.

Foi utilizado como critério de escolha ${ }^{90}$ aspectos técnicos, de licenciamento ambiental e de custos (extensão de dutos submarinos e terrestres, disponibilidade de área adequada para a instalação da unidade, faixa de servidão dos dutos, encaminhamento dos dutos de exportação para Taubaté e afastamento das áreas urbanas ou densamente povoadas). Apesar dos aparentes cuidados na escolha do local para implantação da Unidade de Tratamento de Gás em Caraguatatuba, o empreendimento está interior da antiga Fazenda dos Ingleses (Fazenda Serra Mar), dentro dos limites do Corredor da Serra do Mar, parte do Projeto Corredores Ecológicos, do Ministério de Meio Ambiente, ligado ao Programa Piloto para a Proteção das Florestas Tropicais, o que inclui áreas de elevada biodiversidade e legalmente protegidas.

${ }^{90}$ Motivos apontados pelo EIA para definição do local:

- Áreas planas disponíveis, sem edificaçôes, para a instalação da UTG.

- Capacidade de ampliação para $100 \%$ da área total necessária.

- Dutos terrestres de gás natural livre e com baixa densidade demográfica.

- Duto de gás de venda não necessita passar por São Sebastião.

- Área de baixa densidade demográfica

- Razoavelmente afastada da área urbana. 
O EIA informa que os impactos negativos provocados por esta obra são mínimos (podem ser reduzidos com medidas mitigadoras e compensatórias) em comparação com os benefícios econômicos. ${ }^{91}$

O estudo ao seu final afirma que a Unidade de Tratamento de Gás de Caraguatatuba foi avaliada como um empreendimento viável, técnica, econômica, social e ambientalmente, proporcionando potencialmente benefícios diversos e que poderão oferecer melhoria da qualidade de vida de Caraguatatuba, no Estado de São Paulo e, indiretamente, de outras regiões do Brasil que vierem a fornecer materiais e equipamentos para a implantação da obra, bem como as que vierem a usar o gás natural proveniente da Bacia de Santos.

É importante dizer que a região de Caraguatatuba já vinha sofrendo crescente imigração com muitas ocupações irregulares, responsável pela deterioração urbana e ambiental no município, onde estão presentes os maiores índices de violência do estado de São Paulo. ${ }^{92}$ Uma destas ocupações irregulares deu origem ao bairro do Tinga, localizado nas imediações do local onde foi instalado a Unidade de Tratamento de Gás - UTG.

\subsection{EIA-RIMA - ampliação do Porto de São Sebastião - Plano Integrado Porto Cidade (PIPC SÃO SEBASTIÃO)}

\footnotetext{
$\mathrm{O}$
} EIA-RIMA - ampliação do Porto de São Sebastião foi elaborado pela empresa Consultoria Paulista de Estudos Ambientais, contratada pela Companhia Docas de São Sebastião, para obtenção da Licença Prévia (LP) do Instituto Brasileiro de Meio Ambiente e dos Recursos Naturais Renováveis - IBAMA.

O Governo do Estado pretende ampliar sua capacidade para movimentação de carga na região sudeste com a construção de novos píeres que avançam mar adentro, buscando profundidades naturais de até 25 metros, principalmente para atender os grandes navios que transportam contêineres

\footnotetext{
${ }^{91}$ Principais impactos levantados pelo EIA - Unidade de Tratamento de Gás de Caraguatatuba: Impactos positivos:

- Aumento da disponibilidade de Gás Natural.

- Dinamização da economia local e aumento da oferta de postos de trabalho. Impactos negativo:

- Alteraçáo da rede de drenagem e início e/ou aceleração de processos erosivos.

- Piora da qualidade do ar devido às emissóes atmosféricas.

- Pressão sobre a biota (fauna e flora).

- Interferência no cotidiano da população local.

- Aumento do tráfego de veículos, de ruídos e de poeiras.

- Pressão sobre a infraestrutura de serviços essenciais.

- Interferência sobre o patrimônio arqueológico regional.

- Alteração no uso e ocupação das terras.

${ }^{22}$ Segundo dados do IBGE, dos 76 municípios com mais de 100 mil habitantes do Estado de São Paulo, o município de Caraguatatuba foi considerado em 2013 e pelo terceiro ano consecutivo o mais violento do Estado, com taxa de 28,3 homicídios por 100 mil habitantes, o que significas quase o triplo do índice de todo o Estado.
} 
com capacidade de até 8 mil TEUS, ${ }^{93}$ além da incorporação da Baia do Araçá para viabilizar uma retroárea com mais de 100 hectares.

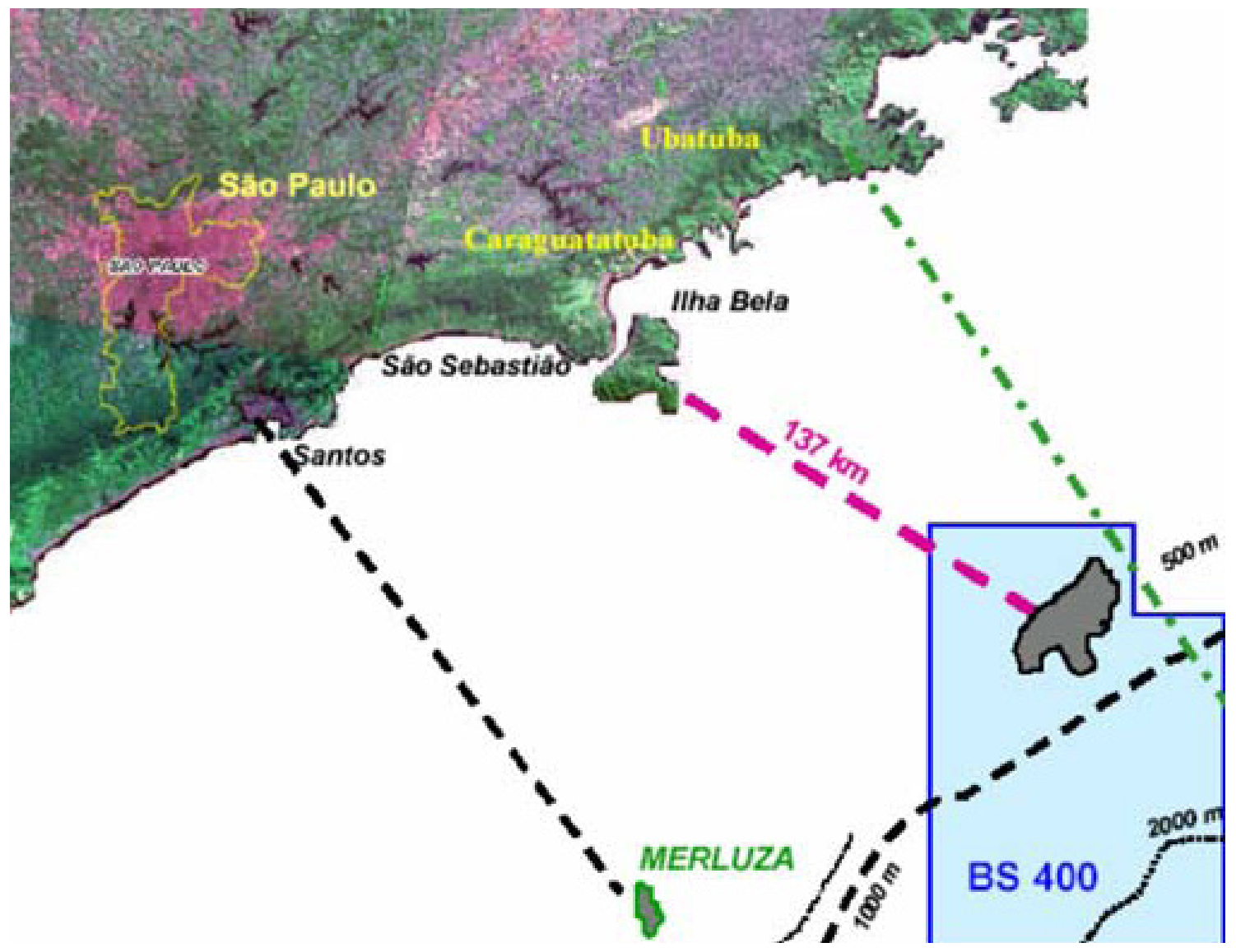

Fonte: EIA-RIMA Unidade de Tratamento De Gás de Caraguatatuba.

Figura 79 - Alternativas para recebimento em terra do gás proveniente da plataforma MexiIhão - Bloco BS 400

\begin{tabular}{|c|c|c|}
\hline \multicolumn{3}{|c|}{ Porto comercial de São Sebastiāo } \\
\hline & Atual & Ampliação \\
\hline Áreas & $400 \mathrm{mil} \mathrm{m}^{2}$ & 1,2 milhão de $\mathrm{m}^{2}$ \\
\hline Berços & 5 & 20 \\
\hline Armazéns & 4 & 6 \\
\hline Tanques & 0 & 8 \\
\hline \multicolumn{2}{|c|}{ Empregos gerados na obra } & 2.800 \\
\hline \multicolumn{2}{|c|}{ Investimento: } & $\mathrm{R} \$ 2,5$ bilhões \\
\hline
\end{tabular}

Fonte: Plano Integrado Porto Cidade • PIPC SÃO SEBASTIÃO (2009).

Tabela 5 - Atuais instalações e as pretendidas para a ampliação do porto

\footnotetext{
${ }^{93}$ TEU - Twenty-foot Equivalent Unit: um TEU equivale a um contêiner de 20 pés.
} 
O estudo aponta vantagens com a ampliação e multimodalidade do porto com a possibilidade de descentralização da capacidade da logística de transportes do estado de São Paulo e da região sudeste. Ressalta sua localização privilegiada e proximidade com o Vale do Paraíba e a região metropolitana de Campinas e considera que o encurtamento de distancias são ganhos ambientais, por menor emissão de poluição e risco de acidente no percurso.

O EIA definiu para este empreendimento o nome de Plano Integrado Porto Cidade (PIPC), cujos principais objetivos são: as obras de ampliação da capacidade portuária através do complexo portuário, retroárea com a construção de laje e estacas em concreto, acrescendo mais $500 \mathrm{mil} \mathrm{m}^{2}$ à área existente, além do acesso principal interligado ao contorno sul e a suposta integração com a cidade.

O estudo reforça que o Canal de São Sebastião oferece características oceanográficas e geomorfológicas apropriadas para um porto, por oferecer abrigo das águas contra o mau tempo, por estar localizada entre o eixo Rio-São Paulo (maior concentração de atividades industriais do Brasil), além das profundidades necessárias aos navios que transportam contêineres, mas conta ao mesmo tempo com dificuldades de acesso, como as grandes declividades dentro da Serra do Mar para atingir o planalto. No Litoral Norte, a configuração geográfica predominante são planícies estreitas, o que resulta em falta de áreas naturais para o retroporto, principalmente na cidade de São Sebastião, local proposto para ampliação do porto. Mesmo assim, o estudo afirma que o local é apropriado para o projeto (Figura 80).

O EIA considerou através do diagnóstico ambiental as áreas de influência que sofrerão efeitos diretos e indiretos decorrentes da ampliação do porto (planejamento, implantação e operação do porto) que correspondem aos espaços físico, biótico, de relaçōes sociais, políticas e econômicas, Área de Influência Indireta (AII), Área de Influência Direta (AID) e Área Diretamente Afetada (ADA).94

Segundo o EIA-RIMA, em um raio de $10 \mathrm{~km}$ de distância da Área Diretamente Afetada do empreendimento o estudo identificou a presença de áreas protegidas tanto por legislação federal quanto estadual e municipal. 95

\footnotetext{
${ }^{94}$ Área de Influência Indireta (AII) - Caraguatatuba, Ilhabela, São Sebastião e Ubatuba. Área de Influência Direta (AID) - efeitos diretos do empreendimento na mancha urbana no entorno do Porto: o centro histórico de São Sebastião, os bairros Topolândia, Vila Amélia, Varadouro, Barequeçaba, Pitangueiras, Guaecá, Porto Grande, Praia Deserta, Pontal da Cruz e Arrastão no município de São Sebastião, e o bairro Barra Velha no município de Ilhabela, no trecho junto à balsa. Para o ambiente aquático, a AID compreende a área do porto organizado no canal de São Sebastião, 10 mil metros ao sul e 10 mil metros ao norte, e na linha de costa desde a ponta da Praia Grande até a Praia de Porto Grande.

Área Diretamente Afetada (ADA) - área destinada à implantação do empreendimento.

${ }^{95}$ Legislação Federal:

- Reserva da Biosfera da Mata Atlântica;

- Áreas Costeiras;

- $\quad$ Áreas de Preservação Permanente (APP);
} 


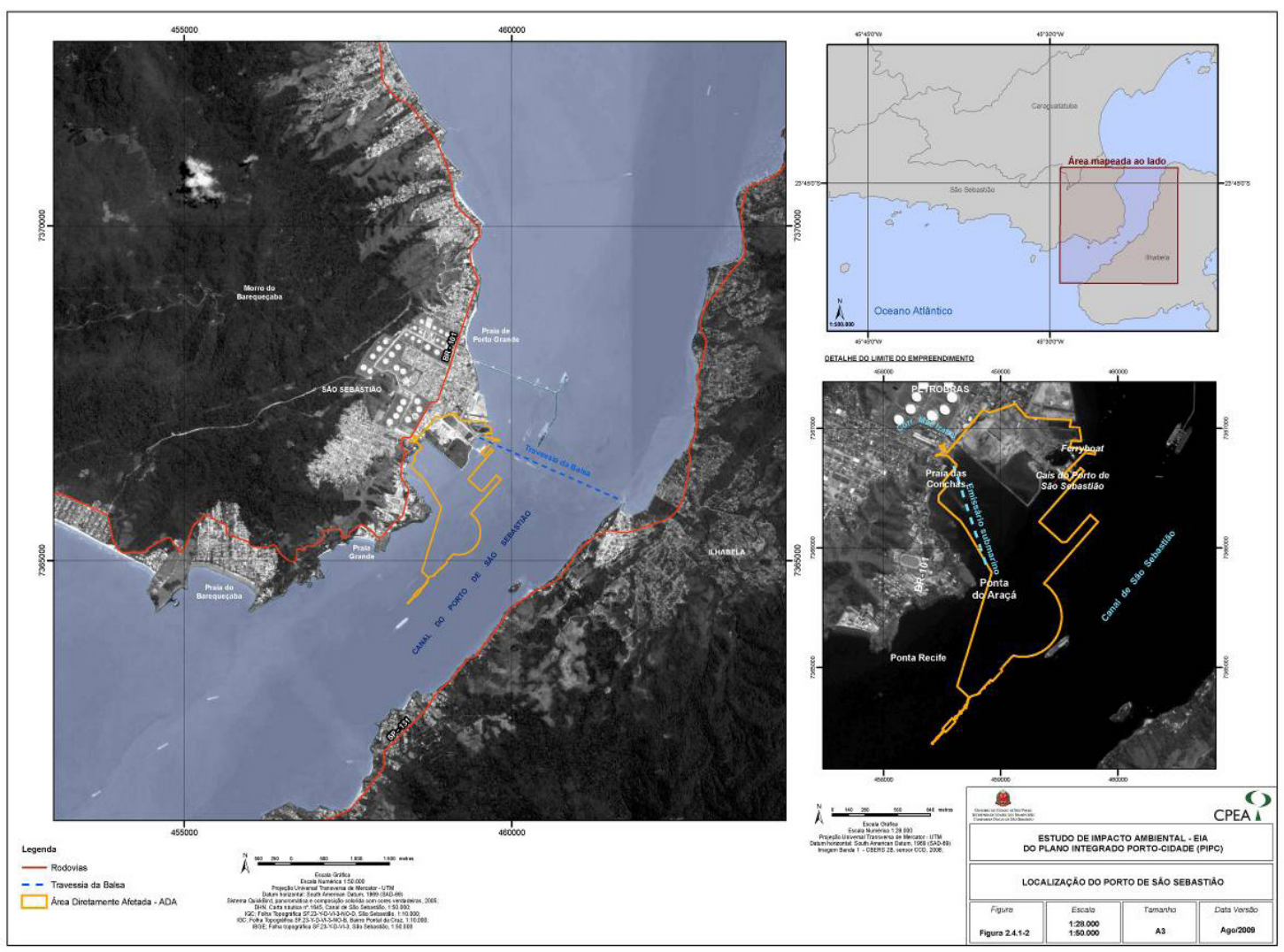

Fonte: Plano Integrado Porto Cidade • PIPC SÃO SEBASTIÃO (2009).

Figura 80 - Localização para ampliação do porto comercial - São Sebastião

Foram apresentadas quatro alternativas para o projeto de ampliação do Porto, mas todas no mesmo local, conforme Figura 81.

A alternativa 1 considerou o aterro de toda a enseada do Araçá, eliminando totalmente os remanescentes de manguezais, as praias, o acesso dos pescadores ao canal e afetando os costões rochosos do Araçá.

A alternativa 2 considera o aterro de $85 \%$ da enseada do Araçá mantendo o canal de acesso aos pescadores. Segundo os estudos, esta alternativa foi a primeira evolução do projeto, considerando a necessidade de preservar o acesso dos pescadores ao Canal de São Sebastião, bem como proteger o ambiente dos costões do Araçá.

- Legislação Estadual:

- Parque Estadual da Serra do Mar - Núcleo São Sebastião;

- Parque Estadual de Ilhabela; Área de Proteção Ambiental Marinha do Litoral Norte;

- Área de Relevante Interesse Ecológico de São Sebastião;

- Área Natural Tombada da Serra do Mar e de Paranapiacaba;

- Áreas Naturais Tombadas: ilhas, ilhotas e lajes;

Legislação Municipal:

- Área de Proteção Ambiental Alcatrazes;

- Área de Proteção Ambiental Ilhota de Itaçucê

- $\quad$ Áreas de Proteção Permanente definidas pela Lei Orgânica do Município. 


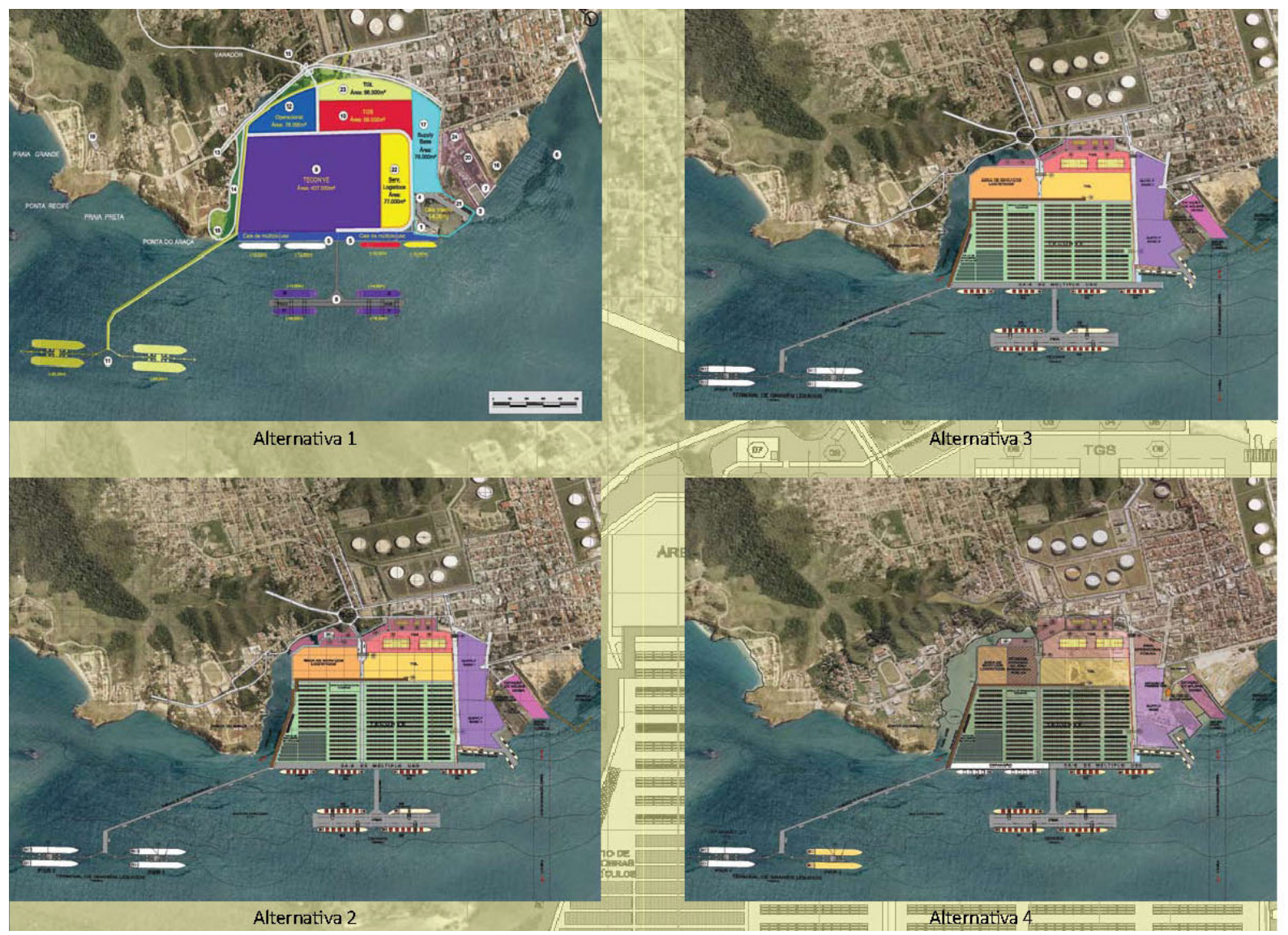

Fonte: Plano Integrado Porto Cidade • PIPC SÃO SEBASTIÃO (2009).

Figura 81 - Ampliação do porto comercial - São Sebastião. Apresentação de quatro alternativas

A alternativa 3 mantém o aterro hidráulico de $80 \%$ da enseada do Araçá, mas amplia o prolongamento do canal de acesso aos pescadores até a praia do Araçá e preserva parte do mangue.

A alternativa 4 é apontada pelo EIA como a melhor do ponto de vista ambiental e econômica e viável tecnicamente. A proposta é de uma laje sobre 75\% da enseada do Araçá, com preservação da ilhota de Pernambuco, manutenção de espelho d'água de acesso aos pescadores até a praia do Araçá, e segundo o estudo permitirá a preservação do manguezal do Araçá, o que é no mínimo muito questionável, já que 75\% ficara em baixo da laje proposta, em permanente escuridão.

O grande desafio deste EIA é conseguir as licenças ambientais para a construção dos píeres para grandes profundidades e das retroáreas, espaços fundamentais para viabilizar economicamente portos que pretendem dar ênfase ao transporte de contêineres.

Os impactos no meio físico ${ }^{96}$ apontados pelo EIA foram considerados temporários, de baixa

${ }^{96}$ Principais impactos no meio físico:

- Possibilidade de ocorrência de processos erosivos superficiais e assoreamento associado.

- Aumento de emissões atmosféricas e dos níveis de ruídos em função da mobilização de máquinas e equipamentos.

- Alteração da qualidade das águas superficiais. 
magnitude, e todo passíveis de controle e mitigação através da aplicação de medidas de controle ambiental das obras civis e de recuperação ambiental.

Os impactos no meio biótico ${ }^{97}$ foram considerados de média magnitude e relevância e passíveis de compensação para a supressão de vegetação e de mitigação, mediante a aplicação de medidas de controle ambiental das obras e monitoramento, de recuperação ambiental e de compensação florestal e ambiental. Apontou também que no Canal de São Sebastião, especificamente junto à praia do Araçá, que ainda possui vegetação de mangue, foram verificadas grande concentração de espécies de peixes como linguados, tortinha, goete, paratis e por espécies de interesse na aquariofilia (cavalo marinho, peixe-cachimbo, peixe-cofre), do pampo e papa-terra na pesca esportiva e alta densidade de crustáceos.

A região do Araçá ainda foi destacada por possuir alta diversidade de espécies, principalmente atribuída a sua heterogeneidade ambiental, sendo uma delas bastante utilizada como alimento pela população que vive nas imediações. Golfinhos, botos e baleias também podem ser encontrados em diversas épocas do ano, com maior incidência no verão, o que indica a qualidade do ambiente. Mesmo com a constatação relevante do meio biótico, o EIA concluiu que a construção da laje e o tamponando de $75 \%$ da Baia do Araçá pode ser considerada de média magnitude, passíveis de compensação.

Os impactos no meio sócioeconômico estão relacionados com as expectativas na comunidade, interferência na atividade da pesca artesanal, demanda por habitações, alteração na paisagem e no uso do solo, alterações nas condições de operação do sistema viário e a degradação de áreas urbanas no entorno do Porto. Para minimizar estes impactos negativos, o EIA propõe medidas de mitigação, como recuperação urbana e compensações, mas não deixa claro o que deveria ser feito. Por outro lado, esclarece que os impactos positivos são de grande importância e permanentes, com a ampliação ${ }^{98}$ da capacidade do Porto de São Sebastião.

Não há como questionar a crescente demanda por portos capacitados para movimentação de contêineres, através de embarcações cada vez maiores, que necessitam de grandes profundidades e ao mesmo tempo muito mais espaço em terra para o depósito destas mercadorias, além da infraestrutura de transporte para dar regularidade de fluxo a este tipo de carga.

\footnotetext{
${ }^{97}$ Principais Impacto no meio biótico:

- Supressão de vegetação.

- Alteração da qualidade das águas costeiras.

- Contaminação de ambientes e organismos aquáticos.

- Risco de invasão de organismos exóticos.

${ }^{98}$ Principais Impacto no meio socioeconômico considerados positivos pelo EIA da ampliação do Porto:

- Alternativa relevante para o comércio exterior brasileiro.

- Incremento do volume de cargas e dos serviços portuários.

- Animação da economia.

- Mudança na estrutura econômica local e regional.

- Geração de empregos diretos e indiretos.

- Ampliação do recolhimento de impostos (ICMS, ISSQN).

- Melhoria da qualidade de vida da população e na estruturação urbana.
} 
O local escolhido para ampliação do porto, ao lado do centro histórico da cidade de São Sebastião, apesar das grandes profundidades oferecidas pelo Canal de São Sebastião, não dispõe de áreas para acomodar o retroporto, ou melhor, elas não existem e deverão ser construídas. Segundo o projeto apresentado, o local escolhido é literalmente em cima do manguezal do Araçá, lugar frágil, protegido e com grandes restrições ambientais regionais (em um raio de $10 \mathrm{~km}$ de distância da Área Diretamente Afetada do empreendimento o estudo identificou a presença de áreas protegidas tanto por legislação federal ${ }^{99}$ quanto estadual ${ }^{100}$ e municipal ${ }^{101}$ ).

Faltam também sistemas de transporte adequados, como rodovias dimensionadas para absorver tanto o movimento existente e previsto do porto bem como o transito local e flutuante nos momentos de temporada.

Além disto, outras alternativas como as ferrovias não foram consideradas. Ou seja, o único sistema para escoar a mercadoria do porto será a duplicação da rodovia dos Tamoios, que já nasce com sua expectativa de vida útil reduzida para menos da metade (dez anos no máximo) caso a ampliação do porto se torne realidade.

O estudo define como solução ideal a alternativa 4, conforme análise anterior, e apresenta os principais impactos negativos do empreendimento e suas respectivas medidas mitigadoras para os seguintes itens:

- Atração de população,

- Aumento da demanda por habitações,

- Dinamização do mercado imobiliário,

- Alterações nas condições de operação do sistema viário,

- Alterações na paisagem,

- Interferência na atividade da pesca artesanal,

- Interferência no patrimônio arqueológico,

- Degradação das áreas urbanas no entorno do porto,

- Descaracterização do centro histórico,

- Demanda por áreas de estacionamento e apoio aos caminhoneiros.

Abaixo analisaremos os principais itens e poderemos constatar que existem fortes evidências de que o EIA-RIMA - Plano Integrado Porto Cidade (PIPC SÃO SEBASTIÃO) é insuficiente como avaliação de impactos ambientais enquanto busca de sustentabilidade urbana.

\footnotetext{
${ }_{99}$ Legislação Federal: Reserva da Biosfera da Mata Atlântica, Reserva do Cinturão Verde da Cidade de São Paulo, Áreas Costeiras e Áreas de Preservação Permanente (APP).

${ }^{100}$ Legislação Estadual: Parque Estadual da Serra do Mar - Núcleo São Sebastião; Parque Estadual de Ilhabela; Área de Proteção Ambiental Marinha do Litoral Norte; Área de Relevante Interesse Ecológico de São Sebastião; Área Natural Tombada da Serra do Mar e de Paranapiacaba e Áreas Naturais Tombadas: ilhas, ilhotas e lajes;

${ }^{101}$ Legislação Estadual: Área de Proteção Ambiental Alcatrazes; Área de Proteção Ambiental Ilhota de Itaçucê e Áreas de Proteção Permanente definidas pela Lei Orgânica do Município.
} 


\section{Descrição}

Contingentes populacio- Impacto negativo indireto, de du- Priorização da contratação de mão de obra lonais são atraídos, em busca ração permanente e irreversível. Sua

das vagas de trabalho que magnitude é média e a relevância

são geradas pela implan- alta.

tação de empreendimentos.

Fontes: RIMA Plano Integrado Porto Cidade • PIPC SÃO SEBASTIÃO - SP (2009).

\section{Tabela 6 - Atração de População}

\section{Evidências:}

Como dar preferência para contração de mão de obra local? Muitas das vagas dependem de qualificação prévia. Com certeza, a maior parte das vagas a serem preenchidas pela população local serão as não qualificadas e consequentemente com salários menores.

O estudo indica não permitir assentamentos em áreas não urbanizadas, mas quais seriam os prováveis locais? Para quantas pessoas? Não deveriam estar mapeados? E as áreas de risco e de proteção ambiental, como evitar a invasão e fiscalizar?

\section{Descrição}

\section{Avaliação}

\section{Medidas mitigadoras}

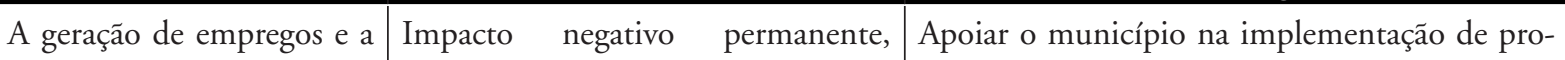
atração de população de- porém reversível pela implantação de gramas habitacionais e aumentar a fiscalização vem acarretar um aumen- programas habitacionais; tem grande para evitar ocupação de áreas de risco ou de proto da demanda por habitaçóes.

Fontes: RIMA Plano Integrado Porto Cidade • PIPC SÃO SEBASTIÃO (2009). teção ambiental.

Tabela 7 - Aumento da demanda por habitações

\section{Evidências:}

O aumento da demanda por habitações está relacionado diretamente com a atração de população, que, aliás, já está em curso, principalmente na região de Caraguatatuba. Qual a estimativa do número de novas residências em função não só da ampliação do porto, mas também considerando os outros empreendimentos que estão em processo de licenciamento como a duplicação da rodovia SP-055 e a exploração da camada pré-sal?

Aqui podemos constatar que é muito subjetivo o que o estudo estabelece como medidas mitigadoras, ou seja, simplesmente apoiar o município na implantação de programas habitacionais e de fiscalização é deixar sob responsabilidade do município um ônus provocado direta e indiretamente pelo empreendimento. Deve ser considerado também toda a infraestrutura que acompanha as habitações, como escolas, postos de saúde, áreas de lazer, transportes, entre outros serviços. 


\section{Descrição}

A divulgação do proje- Impacto negativo, de Por suas características, esse impacto não comporta medito de ampliação do Porto caráter permanente e irre- das mitigadoras específicas. representará um forte in- versível, de grande magnicentivo para a valorização tude e alta relevância. imobiliária e o aumento das transações comerciais, especialmente nas regióes mais próximas das áreas de intervenção.

Fontes: RIMA Plano Integrado Porto Cidade • PIPC SÃO SEBASTIĀO (2009).

Tabela 8 - Dinamização do mercado imobiliário

\section{Evidências:}

A dinamização do mercado imobiliário é mais um dos impactos que já estão em andamento na região.

A valorização de terrenos na Praia da Enseada, por exemplo, limite entre os municípios de São Sebastião e Caraguatatuba, apresentaram alta expressiva nos últimos anos.

$\mathrm{O}$ estudo alega que este tipo de impacto não comporta medidas mitigadoras, mas poderíamos pensar que em parte esta afirmação seja verdadeira. Os municípios poderiam se antecipar e utilizar instrumentos existentes no Estatuto da Cidade para demarcar áreas de preempção, por exemplo, para acomodar a nova população que começa a se deslocar para os municípios da região, evitando com antecedência o aumento do preço da terra, o que fatalmente irá acontecer se nada for feito, provocando inevitavelmente maior pressão nas áreas protegidas.

\begin{tabular}{|l|l|l|}
\multicolumn{2}{|c|}{ Descrição } & \multicolumn{2}{c|}{ Avaliação } \\
\hline $\begin{array}{l}\text { Sobrecarga do sistema } \\
\text { viário local, o que requererá } \\
\text { alterações nas condições de } \\
\text { operação desse sistema. }\end{array}$ & $\begin{array}{l}\text { Impacto negativo, de } \\
\text { grande magnitude, alta } \\
\text { relevância e alta significân- } \\
\text { cia, no contexto geral do } \\
\text { empreendimento. }\end{array}$ & $\begin{array}{l}\text { Construção da via de contorno de Caraguatatuba e São } \\
\text { Sebastião; absorção dos caminhões em período de desem- } \\
\text { baraço dentro dos limites do porto organizado; limitação, } \\
\text { do tráfego de caminhões em vias que não comportem } \\
\text { veículos pesados; implantação do projeto da rotatória; } \\
\text { promoção da regulamentação e outras melhorias viárias. }\end{array}$ \\
\hline
\end{tabular}

Fontes: RIMA Plano Integrado Porto Cidade • PIPC SÃO SEBASTIÃO - SP (2009).

Tabela 9 - Alterações nas condições de operação do sistema viário

\section{Evidências:}

Não existe nenhum estudo viário que amplie o entendimento da mobilidade para a região e que considere a ampliação do porto dentro deste contexto, levando em conta o impacto dos grandes empreendimentos implantados e em processo de licenciamento na região, além do movimento turístico, que atualmente contribui com os congestionamentos gigantescos nos municípios. O sistema viário existente já está defasado há muitos anos e não comporta o movimento viário atual.

O estudo apresenta como medida mitigadora a construção do Contorno Sul, ligando Caraguatatuba à São Sebastiāo, mas é de conhecimento público que a duplicação desta rodovia é uma 
necessidade antiga para resolver os constantes congestionamentos na região. É por este novo sistema viário que será movimentada a carga do porto ampliado, passando de 800 mil toneladas por ano para 25 milhões de toneladas, ou seja os congestionamentos mudaram de lugar e com índices muito maiores.

Conforme já apresentado anteriormente, os estudos do Dersa - Desenvolvimento Rodoviário S/A consideram que à vida útil da duplicação cai de 25 anos para dez anos com a ampliação do porto comercial.

Descrição

Avaliação

Medidas mitigadoras

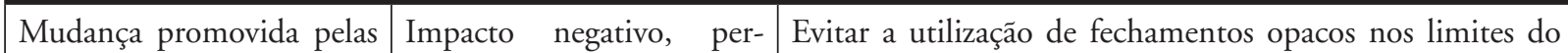
novas estruturas do Porto, manente, irreversível, de Porto, pois ocasionam rupturas com a cidade e criam espela provável verticalização média magnitude (pelas di- paços inseguros e degradados; controlar, através de legisde bairros de São Sebastião mensões da área portuária), lação urbanística competente, a atuação do mercado imoe pela ocupação de áreas até de alta relevância para a biliário e promover programas habitacionais. então desocupadas (encos- região. tas).

Fontes: RIMA Plano Integrado Porto Cidade • PIPC SÃO SEBASTIÃO (2009).

Tabela 10 - Alterações na paisagem

\section{Evidências:}

O estudo não cita a alteração que a própria ampliação do porto irá causar na paisagem da cidade da cidade de São Sebastião e o impacto visual dos inúmeros navios pelo canal, ou seja, o próprio porto não foi avaliado como estrutura que altera a paisagem.

A preocupação apontada pelo estudo neste item é a provável verticalização dos bairros de São Sebastião, mas se considerarmos que os gabaritos máximos são estabelecidos pelos índices urbanísticos da legislação urbana, que já estabelecem o limite destas verticalizações, a preocupação não deveria ser esta.

Sugere como medidas mitigadoras evitar fechamentos opacos nos limites do porto, por considerar que esta solução causa rupturas com a cidade e geram espaços inseguros e degradados. Podemos então considerar que apenas trocar um muro por uma grade é uma medida mitigadora para um empreendimento deste porte?

Sugere como mitigação uma legislação urbanística competente, para controlar a atuação do mercado imobiliário e promover programas habitacionais.

A legislação urbanística competente, sugerida pelo estudo, deveria ser a mesma para controlar e exigir do empreendedor uma verdadeira proposta de desenho urbano que qualificasse de fato a relação porto-cidade. 
Descrição

Ocorrência de impedimen- Impacto negativo, permatos ao desenvolvimento da nente e reversível.

atividade pesqueira nos lo- Sua magnitude foi consicais tradicionais, levando os derada pequena levando-se pescadores a buscar novas em conta a área que pode áreas de pesca ou outras ser afetada e a relevância foi atividades produtivas.

Fontes: RIMA Plano Integrado Porto Cidade • PIPC SÃO SEBASTIĀO (2009).
Compensação na forma de educação e incentivo a outras atividades, com vistas à geração de renda para as comunidades afetadas.

\section{Tabela 11 - Interferência na atividade da pesca artesanal}

\section{Evidências:}

O estudo considera o impacto como pequeno na pesca artesanal, mesmo observando que a ampliação do porto possa ocasionar o impedimento do desenvolvimento das atividades pesqueiras nos locais tradicionais, fazendo que os pescadores busquem novas áreas de pesca e até outras atividades produtivas.

Se o estudo considera pequena a interferência na pesca artesanal, e ainda sugere que a mitigação seja na forma de educação e incentivo a outras atividades, podemos concluir que o impacto é extremo, pois não leva em conta costumes e tradições do povo local.

\section{Descrição}

Avaliação

Conjunto de alterações que Impacto negativo, perma- Programa de Mitigação de Impactos sobre o Patrimônio a obra projetada (ou o uso nente e reversível; a magni- Arqueológico, que inclui diretrizes para o monitoramendo solo) venha causar nos tude do impacto é grande to terrestre e subaquático e a oferta de educação patrimobens arqueológicos e ao seu assim como a relevância. contexto, impedindo que a herança cultural das gerações passadas seja transmitida.

Fontes: RIMA Plano Integrado Porto Cidade • PIPC SÃO SEBASTIÃO (2009).

Tabela 12 - Interferência no patrimônio arqueológico

\section{Evidências:}

O manguezal do Araçá e seu entorno, escolhidos como área para ampliação do porto, é reconhecido como local tradicionalmente utilizado pelos caiçaras e pescadores.

Os estudos poderiam ter sido aprofundados, antecipando as probabilidades de encontrar ou não vestígios arqueológicos durante as obras.

\section{Descrição}

Perda das características das Impacto negativo, perma- $\quad$ Absorção integral pelo Porto de suas atividades, provenruas do entorno do Porto e nente e reversível, de média do espaços logísticos para estacionamento e manobras, da paisagem original, pela magnitude, porém de alta capazes de evitar o transbordamento de maquinários ou imposição de novos usos relevância. relacionados à atividade portuária. caminhões para a cidade.

Fontes: RIMA Plano Integrado Porto Cidade • PIPC SÃO SEBASTIĀO (2009).

Tabela 13 - Degradação das áreas urbanas no entorno do porto 


\section{Evidências:}

A degradação das áreas no entorno do porto é considerada de alta relevância e permanente, mas segundo o estudo é reversível pelo simples fato de que os espaços logísticos são suficientes para acomodar integralmente todas as suas atividades, inclusive maquinários e caminhões.

Um porto para contêineres pode em um curto espaço de tempo necessitar de novas áreas para ampliar e se tornar mais competitivo. Existe um grande risco de "transbordamento" das atividades portuárias, ou por falta de espaço dentro das instalações portuárias ou até por tarifas mais atraentes para estoque de cargas e estacionamento de caminhões em outros locais.

A própria circulação dos caminhões pode levar a degradação urbana muito além do entorno imediato do porto.

\begin{tabular}{|l|l|l|}
\hline \multicolumn{1}{|c|}{ Descrição } & \multicolumn{2}{c|}{ Medidas mitiação } \\
\hline $\begin{array}{l}\text { Aumento de área construí- } \\
\text { da nos imóveis existentes e } \\
\text { as adaptações que se fazem } \\
\text { necessárias poderão resultar } \\
\text { na descaracterização dos negativo, per- } \\
\text { manente e irreversível, de } \\
\text { prédios históricos. }\end{array}$ & $\begin{array}{l}\text { O centro histórico deverá ser alvo de políticas de proteção, } \\
\text { com intensificação da fiscalização municipal e do CON- } \\
\text { relevância. }\end{array}$ & $\begin{array}{l}\text { DEPHAAT, a fim de evitar a descaracterização das edi- } \\
\text { ficações e o controle de tráfego no perímetro tombado. }\end{array}$ \\
\hline Fontes: RIMA Plano Integrado Porto Cidade • PIPC SÃO SEBASTIÃO (2009).
\end{tabular}

Tabela 14 - Descaracterização do centro histórico

\section{Evidências:}

A descaracterização do centro histórico da cidade de São Sebastião também é considerada de pequena magnitude pelo EIA, apesar de afirmar que é permanente e irreversível.

Se é irreversível, há evidências de que a ampliação do porto será a responsável pela degradação final do centro histórico, que já sofre as consequências negativas da construção do aterro em sua frente marítima, autorizado por outro EIA-RIMA do Aterro do Centro Histórico de São Sebastião, elaborado na década de 1980, conforme já abordamos.

$\mathrm{O}$ atual EIA considera apenas como medidas mitigadoras políticas de proteção e fiscalização municipal, para evitar degradação e descaracterização das edificações, além de controlar o trafego no setor tombado.

As medidas propostas para mitigar os impactos negativos no centro histórico são atribuições declaradas na Constituição Federal e Estadual e são de responsabilidade do município, o que já deveria ter sido questionado ao empreendedor no momento da análise do documento.

Um empreendimento desta magnitude, com reais possibilidade de provocar ainda mais a degradação e descaracterização do centro histórico, deveria ter sido evidenciado nas análises dos estudos e não apenas creditar à prefeitura municipal o ônus de evitar o provável cenário negativo, com a ampliação do porto, localizado apenas à 300 metros de distância do centro histórico. Falta um projeto urbano qualificado que desenhe o porto e a cidade em conjunto, uma verdadeira, responsável e equilibrada interface. 


\section{Descrição}

Necessidade de áreas ade- Impacto negativo, perma- Provisão de espaços para estacionamento e manobras quadas e seguras para o nente e reversível. $\quad$ e regulamentação das áreas de tráfego permitido para estacionamento de cami- Tem grande magnitude e veículos pesados. nhões que se dirigem ao alta relevância.

Porto, enquanto aguardam permissão para adentrar ao Porto, ou que necessitam de algum reparo.

Fontes: RIMA Plano Integrado Porto Cidade • PIPC SÃO SEBASTIÃO (2009).

Tabela 15 - Demanda por áreas de estacionamento e apoio aos caminhoneiros

\section{Evidências:}

Foi apontado anteriormente, no item "Degradação das áreas urbanas no entorno do porto", que o porto deveria ser responsável pela absorção integral de suas atividades. Agora o próprio estudo reconhece que haverá demanda por novas áreas de estacionamento de caminhões e apoio aos caminhoneiros e sugere provisão destes espaços e ainda regulamentação de áreas permitidas para veículos pesados, ou seja, o porto necessariamente deverá crescer para ampliar sua competitividade.

Agora apresentaremos os principais impactos que o EIA-RIMA da ampliação do porto comercial considera como aspectos positivos com a ampliação do porto. Poderemos constatar que mesmo os aspectos considerados positivos podem ser interpretados também como insuficientes enquanto busca de sustentabilidade urbana.

\section{Descrição}

A intervenção tornará o Impacto positivo, pois ambiente no fundo da aumentaria consideravelBaía do Araçá ainda mais mente a área recoberta abrigado, e favorecerá a deposição de sedimentos e ampliação da planície de maré existente.

Tais fatos, associados à chegada de água doce proveniente do córrego Mãe Isabel, poderão tornar o ambiente mais adequado e favorável ao estabelecimento de plantas de mangue.

Fontes: RIMA Plano Integrado Porto Cidade • PIPC SÃO SEBASTIÃO (2009). pelo ecossistema do manTerá média magnitude, mas alta relevância, considerando a escassez de manguezais na região.

(n)
-

\section{Medidas mitigadoras}

Monitoramento dos manguezais remanescentes, a fim de se acompanhar a dinâmica destes, direcionando as açôes posteriores, conforme as necessidades, de acordo com o Programa de Conservação dos Manguezais.

Tabela 16 - Criação de condições propícias ao estabelecimento de manguezal

\section{Evidências:}

O tamponamento da Baía do Araçá, com lajes sobre pilotis em $600 \mathrm{mil} \mathrm{m}^{2}$ sobre o manguezal do Araçá, foi considerado pelo estudo como um impacto positivo. Afirma que esta solução tornará o ambiente no fundo da baía do Araçá ainda mais abrigado, o que será favorável ao estabelecimento de plantas de mangue. 
Podemos afirmar, e sem a necessidade de grandes aprofundamentos técnicos, que com o tamponamento teremos $600 \mathrm{mil} \mathrm{m}^{2}$ a menos de mangue. Um local sem a penetração de luz, escuro e sem vida, o que não podemos considerar como um aspecto positivo.

\section{Descrição Avaliaçáo $\quad$ Medidas mitigadoras}

Demanda por mão-de- Impacto positivo de ca- Como se trata de um impacto positivo, as medidas indicadas obra direta e indireta para ráter temporário na fase assumem um caráter potencializador. Para garantir a efetiva realização dos serviços de obras e permanente contratação de trabalhadores locais, sempre que possível, nos requeridos pelas obras de na fase de operação, com novos postos de trabalho a serem criados, é proposto um proampliação do Porto. $\quad$ grande magnitude e alta grama de contratação e formação de mão-de-obra. relevância

Fonte: EIA - Anexo 18, Capitulo 8 - Identificação e Avaliação de Impactos Ambientais. Pág. 77 (2009).

\section{Tabela 17 - Geração de empregos e renda}

\section{Evidências:}

Os empregos e renda gerados pela ampliação do porto, tanto na fase de implantação quanto na fase de operação são impactos positivos, desde que seja dada a prioridade à contratação de mão de obra local, o que o estudo recomenda. O que seria importante destacar, e que não foi estudado, é a quantidade de emprego qualificado e não qualificado que um porto baseado em carga de contêineres necessita e qual o rebatimento na infraestrutura da cidade e região.

\begin{tabular}{l|l}
\multicolumn{2}{|c|}{ Descrição Avaliação } \\
\hline
\end{tabular}

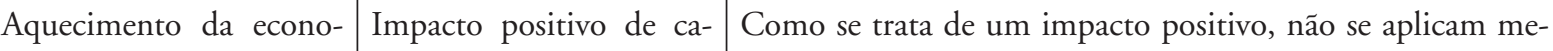
mia devido ao surgi- ráter temporário na fase didas mitigadoras, mas de caráter potencializador. Sempre mento de oportunidades de obras e permanente que possível, das empresas e outros prestadores de serviços para realização de novos na fase de operação, com locais, o empreendedor deverá garantir, contratualmente, a negócios comerciais e de grande magnitude e alta priorização da contratação de empresas e outros prestadores

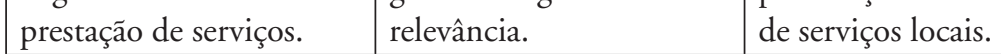

Fontes: RIMA Plano Integrado Porto Cidade • PIPC SÃO SEBASTIÃO - SP (2009).

\section{Evidências:}

A animação da atividade econômica é compreendida pelo EIA apenas como um aspecto positivos e por esta razão não cabem medidas mitigadoras e/ou compensatórias. Se pensarmos que maior atividade econômica significa também maior consumo e pressão nas infraestruturas existentes (transporte, saúde, educação e habitação, por exemplo), ou até a falta delas para atender um maior fluxo de pessoas interessadas em participar da "animação econômica" descrita pelo estudo, sem falar na elevação do consumo de energia e água, além de maior produção lixo, esgoto, poluição diversas (sonora, mais $\mathrm{CO}^{2}$ lançado na atmosfera), fica evidente que não deveríamos considerar apenas o impacto positivo neste caso.

A falta de estudos que compreendam a ampliação do porto e os impactos no meio urbano promovidos pelo aquecimento na economia e oportunidade para novos negócios transferem o ônus ao poder público, que deverá arcar sozinho, a médio e longo prazo, com as novas demandas urbanas. 


\section{Descrição}

\begin{tabular}{|ll|l|l} 
Aumento da ar- & Impacto positivo de caráter tem- & Não se aplicam medidas mitigadoras.
\end{tabular}

recadação de im- porário na fase de obras e perma-

postos, implicando nente na fase de operação, com

na melhoria das fi- grande magnitude e alta relevân-

nanças públicas. cia.

Fontes: RIMA Plano Integrado Porto Cidade • PIPC SÃO SEBASTIÃO - SP (2009).

\section{Tabela 19 - Aumento das receitas fiscais}

\section{Evidências:}

Não basta apenas o aumento das receitas fiscais se não houver uma relação, como os custos envolvidos para suprir as demandas existentes e as decorrentes do aumento de sua população. Nova infraestrutura deverá ser ampliada e/ou construída antecipadamente e gerida.

\begin{tabular}{|l|l|l|}
\hline \multicolumn{1}{|c|}{ Descrição } & \multicolumn{2}{c|}{ Avaliação } \\
\hline $\begin{array}{l}\text { Ampliação da capacidade } \\
\text { do Porto de São Sebastião }\end{array}$ & $\begin{array}{l}\text { Impacto positivo, per- } \\
\text { manente. Possui grande }\end{array}$ & Não se aplicam medidas mitigadoras. \\
para atender às novas & \\
demandas de movimen- & & \\
magnitude e relevância. & \\
à inde cargas, de apoio & & \\
do gás, e de consolidação & & \\
do setor de turismo. & & \\
\hline
\end{tabular}

Tabela 20 - Desenvolvimento da infraestrutura portuária e de apoio

\section{Evidências:}

O EIA considerou a alternativa de não execução do projeto, mas ao mesmo tempo afirma a importância de sua implantação justificando a falta de infraestrutura portuária deste porte na região sul/sudeste, ressaltando a demanda existente, e que ainda utiliza as características naturais do lugar se referindo às profundidades naturais do canal, favoráveis à implantação de um porto marítimo.

Considera que a não implementação desse projeto privará a economia, o meio ambiente e a qualidade de vida da população desses benefícios, caso o crescimento da demanda portuária e logística seja absorvida pelo Porto de Santos ou portos de estados vizinhos.

Infelizmente, não foi contemplada uma diferente configuração portuária que pudesse investir em outro tipo de carga mais especializada, como por exemplo carga de projeto, nacionais e internacionais, que poderiam ser estocadas e montadas dentro da área alfandegária no Porto de São Sebastião.

O sistema consiste em usar as instalaçôes existente para que peças possam ser acopladas e embarcadas novamente para seu destino final. A própria Petrobras utilizou o porto comercial como base para implantação e construção do gasoduto na plataforma de Mexilhão. Além da utilização dos berços 202 e 203 para embarque e desembarque dos equipamentos, utilizou a zona secundária portuária como canteiro de obra para a construção das plataformas. 
Um projeto mais amplo poderia redirecionar determinados tipos de cargas, onde o Porto de Santos, o Porto de São Sebastião e portos de estados vizinhos não seriam concorrentes diretos, mas, sim, parceiros dentro de uma organização regional e sustentável para definir os diversos fluxos e tipos de cargas, respeitando as características geográficas, ambientais e urbanas de cada local.

A ampliação do porto busca principalmente viabilizar a operação de contêineres, o que pode ser um erro já que o porto de Santos ${ }^{102}$ ainda é muito mais interessante para este tipo de carga, por possuir regularidade de frequência, o que dificilmente São Sebastiāo conseguirá ter. Hoje são três milhões/ano, mas como tirar 27 milhōes/ano previstos pelos estudos? Como "tirar" a carga de dentro do Porto de São Sebastião, apenas por uma rodovia, que está sendo duplicada, mas subdimensionada para o fluxo pretendido.

Outros modais não estão sendo cogitados, como, por exemplo, a implantação de um sistema ferroviário. ${ }^{103}$

Apesar de todas as especificidades deste território, o EIA-RIMA PIPC concorda com a inserção estratégica do empreendimento nas políticas de desenvolvimento do Estado, com um projeto de engenharia, que segundo o relatório, atende às questôes ambientais, com um porto multiuso, movimentando contêineres, carga geral e granéis sólidos e líquidos, e que ainda ameniza a transição entre a área de operação portuária e a área urbana.

Finalmente, atesta pela viabilidade ambiental do Plano Integrado Porto Cidade - PIPC a partir dos estudos técnicos apresentados, considerando que as condições das áreas a serem direta ou indiretamente afetadas pelas ações do empreendimento serão de ganho ambiental após a implantação dos programas sugeridos, mas quando vemos a imagem do projeto que representa ampliação do porto (Figura 82), fica difícil acreditar que o centro da cidade de São Sebastião suportará o impacto deste empreendimento com qualidade ambiental e muito menos terá ganhos urbanos.

\footnotetext{
${ }^{102}$ Apesar disto, o Porto de Santos pode entrar em colapso por falta de planejamento do Estado. O tempo de permanência dentro do Porto de Santos gira em torno de 15 a 17 dias no ano de 2014. Em outros portos do mundo este processo dura em média de 3 a 4 dias. Os portos secos no interior, como Bauru e Sorocaba, estão ociosos. Atualmente, as rodovias que interligam o Porto de Santos ao interior tem uma capacidade de reserva. Para utilizar, o governo precisa intervir (Dersa e Ecovias) para um uso mais racional da infraestrutura existente e aumentar sua produtividade. As rodovias estão mais vazias das 20 horas às 6 horas, o que justificaria tarifas de pedágios mais baixas, e somado ao policiamento e monitoramento, auxiliaria a viabilizar o Porto 24 horas.

${ }^{103}$ Poderíamos supor que a Petrobras irá priorizar sempre que possível o transporte sobre pneus, já que uma de suas matérias primas tem como objetivo fabricar os próprios pneus. Com isto, a possibilidade de ferrovia no Brasil será sempre uma um assunto não prioritário.
} 


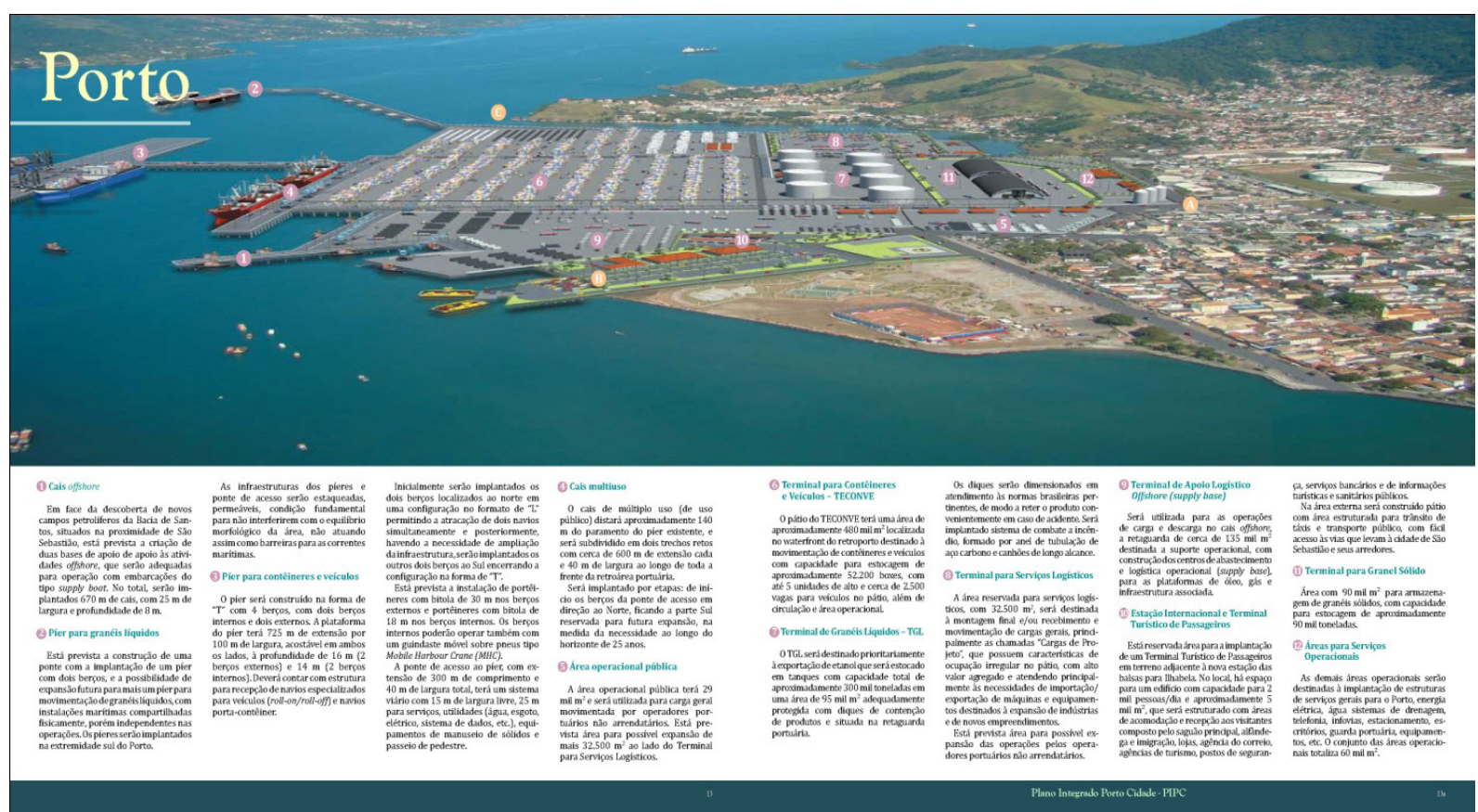

Fonte: Plano Integrado Porto Cidade • PIPC SÃO SEBASTIÃO (2009).

Figura 82 - São Sebastião em 2030. A cidade suportará o impacto do projeto apresentado?

\subsection{Ampliação do porto para contêineres e suas consequências}

análise das possíveis consequências da ampliação do porto comercial de São Sebastião, com
escoamento dos contêineres apenas pelo modal rodoviário, e estimativa de 750 caminhões por hora, evidencia que a obra provocará novos e constantes congestionamentos na região e estradas, o que já ocorre hoje em dia, sem falar no congestionamento náutico, provocado principalmente pelos novos terminais para os meganavios transportadores de contêineres. ${ }^{104}$ Navios deste porte terão condições de atracar no Porto de São Sebastião transportando em torno de 1.820 contêineres (Figura 83). Se cada caminhão pode carregar apenas um contêiner, significa então que 1.820 caminhões chegando ou saindo do porto serão necessários para atender apenas um navio.

Será evidente uma busca das transportadoras por terrenos e tarifas mais vantajosas para estocar seus contêineres fora da área do porto, além de estacionamentos para caminhōes também fora do setor portuário.

Com a ampliação do porto para contêineres, fica claro que o projeto apresentado avança sobre a cidade, seu centro histórico e principalmente em direção as áreas ambientalmente frágeis, pressionando ainda mais a Serra do Mar, a Mata Atlântica e a Baia do Araçá (mangue que será ocupado como área de estocagem de contêineres entre outras atividades portuárias).

\footnotetext{
${ }^{104}$ Contêiner - Criado por J.P.Mclean, foi uma revolução no transporte marítimo e nas operações portuárias - 1956.
} 
(...) Inserida em uma das mais belas e turisticas regiōes litorâneas do país - o Litoral Norte do Estado de São Paulo - a Baía do Araçá (São Sebastiāo, SP), além de conter remanescentes de manguezal e de abrigar alta diversidade biológica, é também um verdadeiro laboratório a céu aberto e um importante reduto de catadores de moluscos e pescadores artesanais. Com o objetivo de compilar preliminarmente a biodiversidade da baia, este estudo reune a extensa bibliografia dedicada à regiāo e apresenta a lista das espécies da fauna e da flora formalmente reportadas para o local. O texto sumaria ainda o histórico das alteraçôes antrópicas sofridas nas últimas décadas e destaca certos representantes da fauna (espécies novas, ameaçadas de extinção, bioindicadoras e como recursos naturais), como exemplos da peculiaridade e riqueza biológica dessa pequena baía. Pretende-se, assim, fornecer subsidios para tomadas de decisão e planos de manejo, e despertar a atenção para a preservação desse frágil patrimônio ambiental, uma área que pode ser revitalizada e integrada ao ambiente urbanizado.

(AMARAL, A.C.Z., MIGOTTO, A.E., TURRA, A. \& SCHAEFFER-NOVELLI. Jan/Mar 2010 vol. $\left.10, \mathrm{n}^{\circ} .1\right)$

É evidente que a região será um polo de atração econômica, mas que por falta de infraestrutura e planejamento desencadeará o processo de favelização nas áreas vizinhas, ampliando o crescimento dos aglomerados de baixa renda que, aliás, já avançam sobre a Serra do Mar, além de ampliar todos os índices de violência na região.

A cidade de São Sebastião já vem perdendo a cada dia seu status de centro do município, o que se agravara com a ampliação do porto. As praias começam a conquistar sua independência, provocando ainda mais dispersão urbana, o que resulta em um extensivo consumo de território e de recursos naturais com a disseminação de mais condomínios e loteamentos fechados, com a substituição da vegetação nativa por espécies exóticas, e maior produção de lixo, entulho e esgoto não tratado. Com certeza, a falta de planejamento desencadeará consequências negativas (conforme Tabela 21) e uma maior degradação dos recursos naturais, com uma ocupação e um consumo extensivo do território litorâneo pressionando ainda mais os setores protegidos por lei.

\subsection{Considerações finais dos EIA em São Sebastião}

$\Lambda_{\text {ano base e ano meta, evidenciam o subdimensionamento das infraestruturas necessárias para }}$ suprir as novas demandas para a região em função dos novos empreendimentos, como, por exemplo a duplicação da rodovia dos Tamoios.

A análise também é precária no entendimento do mercado imobiliário, do sistema de mobilidade urbana, da paisagem natural, da pesca artesanal, do patrimônio arqueológico e, no caso da ampliação do porto comercial de São Sebastião (EIA-RIMA não propõe outros cenários locacionais), é conferida pouca preocupação com o centro histórico da cidade de São Sebastião. 


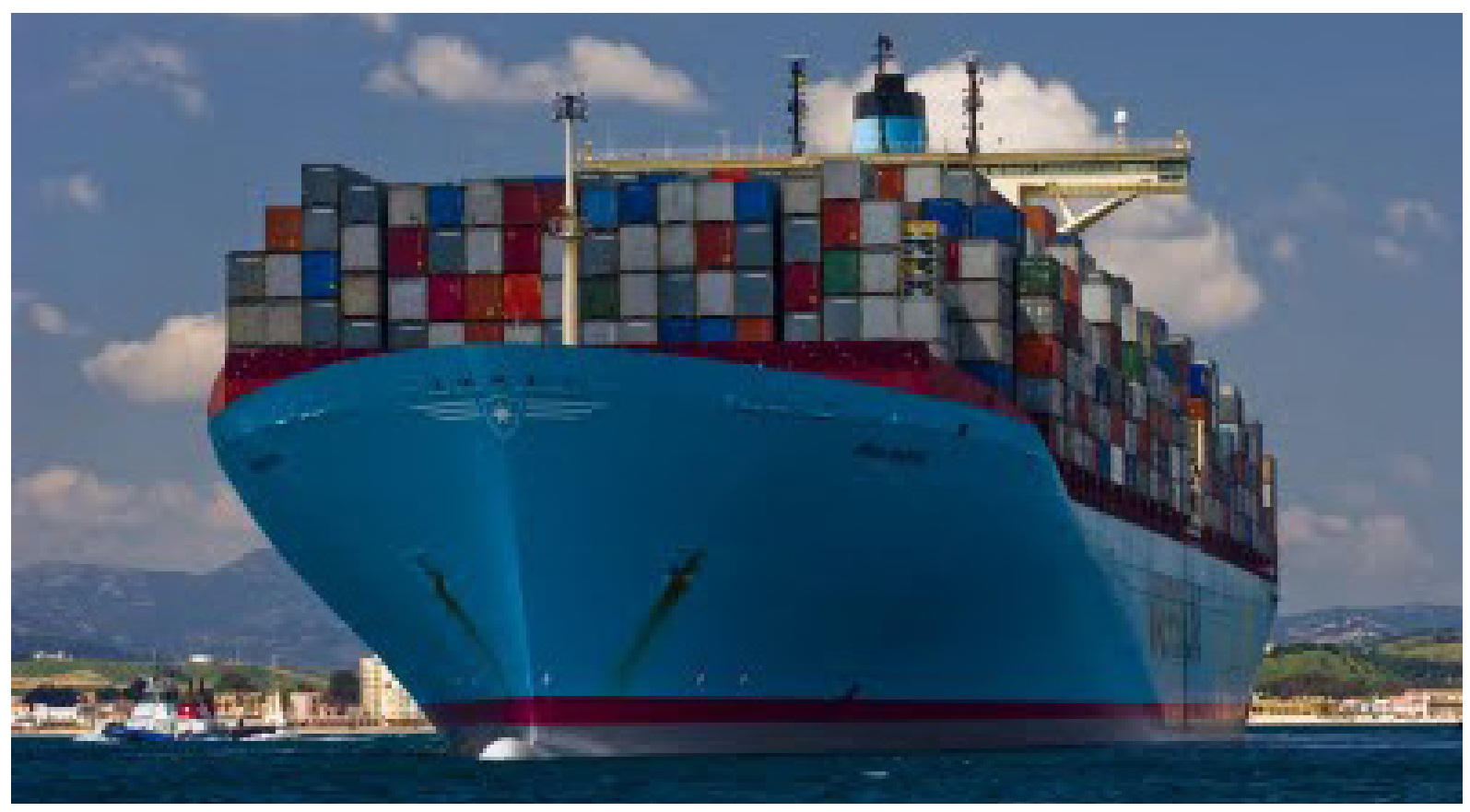

Fonte: http://gigantesdomundo.blogspot.com.br/2011/05/o-maior-navio-cargueiro-do-mundo.html

Figura 83 - Com 397 metros de comprimento e 63 metros de largura, o Emma Maerks é atualmente o maior navio de contêineres do mundo, operando no maior porto do mundo, em Rotterdam, na Holanda.

\begin{tabular}{|l|l|}
\hline No & \multicolumn{1}{|c|}{ Consequências negativas para a região } \\
\hline $\mathbf{0 1}$ & Transportadoras buscando outros terrenos para estocar mais contêineres \\
\hline $\mathbf{0 2}$ & Estacionamento de caminhões dentro e fora do setor portuário. \\
\hline $\mathbf{0 3}$ & Escoamento apenas por caminhões - estimativa de 750 caminhões por hora. \\
\hline $\mathbf{0 4}$ & Novos e constantes congestionamentos na região e estradas. \\
\hline $\mathbf{0 5}$ & Porto vai avançar sobre a cidade e áreas ambientalmente frágeis. \\
\hline $\mathbf{0 7}$ & Favelização - crescimento dos aglomerados de baixa renda nas áreas vizinhas. \\
\hline $\mathbf{0 8}$ & Maior pressão na Mata Atlântica. \\
\hline $\mathbf{0 9}$ & Comprometimento da biodiversidade. \\
\hline $\mathbf{1 0}$ & Baía do Araçá - mangue com grande importância ambiental será ocupado pelo porto. \\
\hline $\mathbf{1 1}$ & Novo terminal para meganavios (Póspanamax) - congestionamento náutico. \\
\hline $\mathbf{1 2}$ & Impacto negativo no turismo. \\
\hline $\mathbf{1 3}$ & Impacto negativo no ambiente e paisagem. \\
\hline $\mathbf{1 4}$ & Falta de infraestrutura adequada e em tempo para atender novas demandas. \\
\hline $\mathbf{1 5}$ & São Sebastião perde o caráter de centro de cidade - praias conquistam sua independência. \\
\hline $\mathbf{1 6}$ & Dispersão urbana - consumo extensivo do território e dos recursos naturais. \\
\hline $\mathbf{1 7}$ & Disseminação de condomínios e loteamentos fechados. \\
\hline $\mathbf{1 8}$ & Maior produção de lixo, entulho e esgoto não tratado. \\
\hline $\mathbf{1 9}$ & Paisagismo com a substituição da vegetação nativa por espécies exóticas. \\
\hline $\mathbf{2 0}$ & Excesso de tráfego de veículos. \\
\hline $\mathbf{2 1}$ & Degradação dos recursos naturais - ocupação e consumo extensivo do território. \\
\hline
\end{tabular}

Tabela 21 - Consequências negativas para a região. 
Podemos concluir, com a análise críticas dos diversos EIA-RIMA anteriormente apresentados, que as medidas sugeridas para a mitigação ou compensação dos impactos negativos são mínimas, pouco claras, sem sinergia entre os diversos empreendimentos (Figura 84) e que existem fortes indícios de que serão insuficientes para garantir a sustentabilidade ambiental e urbana.

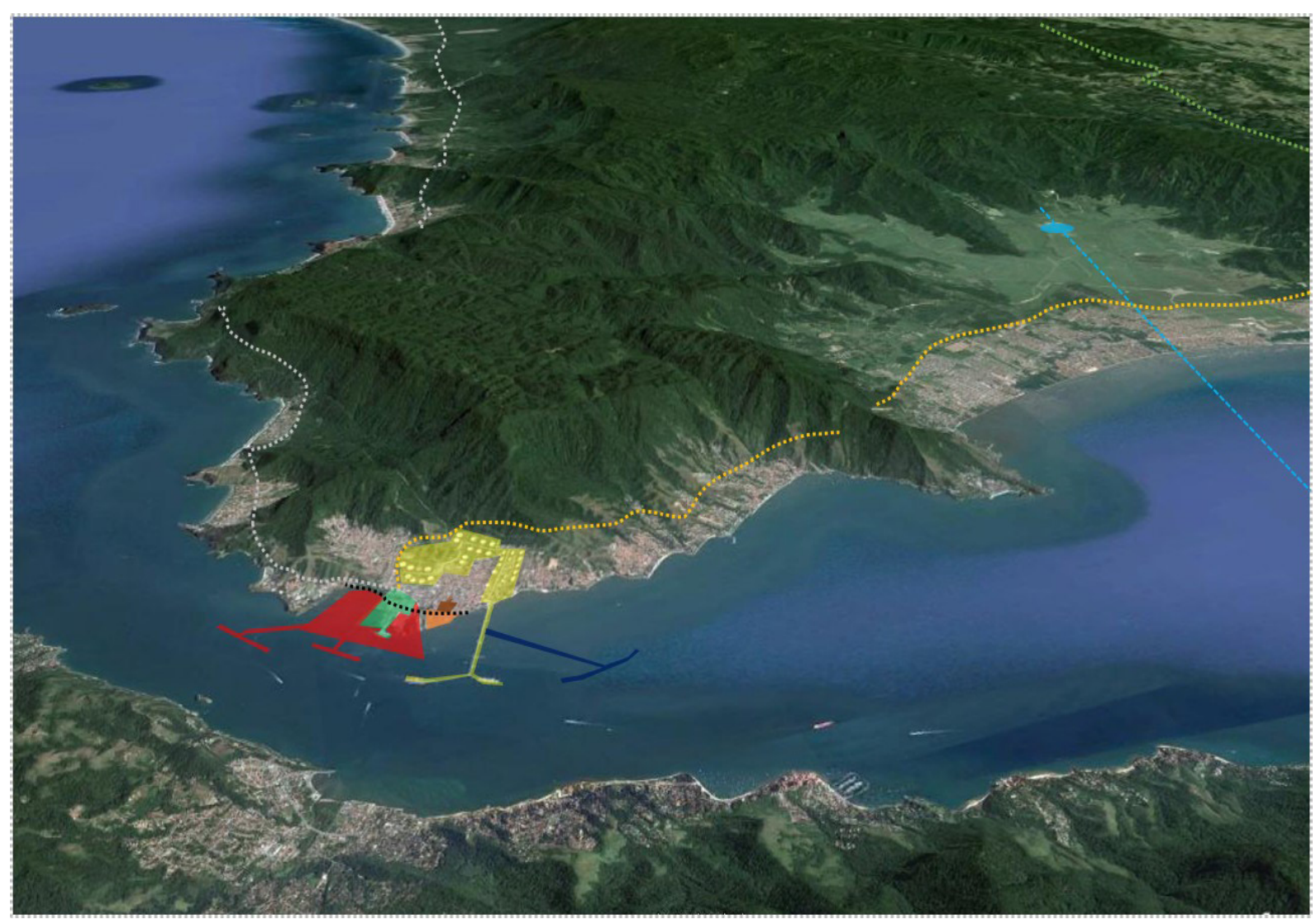

Fonte: Google (2014), organizado por José Francisco Xavier Magalhães.

Figura 84 - Espacialização dos principais empreendimentos na região do Porto de São Sebastião. Não está presente em nenhum dos EIA-RIMA estudados anteriormente para compreender os efeitos cumulativos e sinergéticos em uma mesma base de dados.

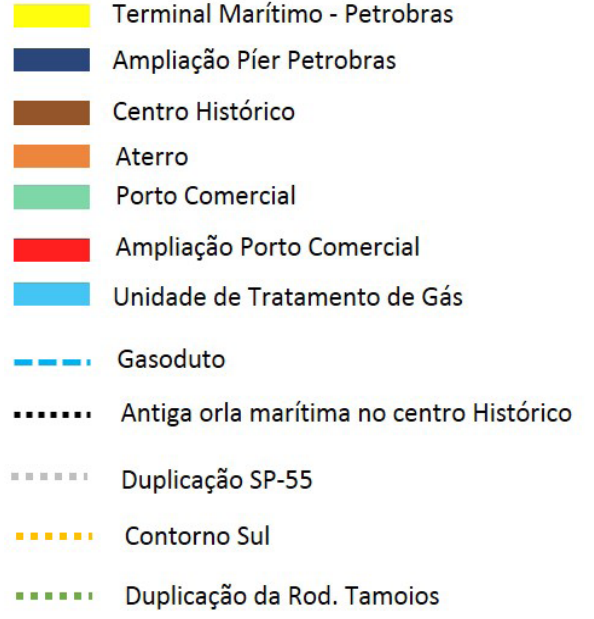


Região Metropolitana do Vale do Paraíba e Litoral Norte Uma alternativa para a região costeira 
$\mathrm{E}$ m 9 de janeiro de 2012, através da Lei Complementar no 1.166, foi criada a Região Metropolitana do Vale do Paraíba e Litoral Norte (RMVPLN), a quarta região metropolitana a ser constituída (figura 85) no Estado de São Paulo, ${ }^{105}$ com uma população de aproximadamente 2,3 milhões de habitantes, uma oportunidade para identificar ações de planejamento e políticas públicas integradas para o crescimento e desenvolvimento da região, além de identificar o potencial de cada cidade.

Um instrumento de planejamento e integração importantes para um território de grandes interesses, onde os setores automobilístico, aeroespacial, petrolífero, farmacêutico, portuário, científico e tecnológico na cidade de São José dos Campos (Instituto Nacional de Pesquisas Espaciais - Inpe, Departamento de Ciência e Tecnologia Aeroespacial - DCTA, Empresa Brasileira de Aeronáutica - Embraer e o Instituto Tecnológico de Aeronáutica - ITA), e a "indústria" do turismo religioso, disputam espaço e mercado em uma região ambientalmente vulnerável, com mais de $36 \%$ de seu território protegidos, contendo 24 Unidades de Conservação, Serra da Mantiqueira e o Parque Estadual da Serra do Mar (Figura 86).

Uma área territorial com 16.179,95 km² e, segundo dados da EMPLASA (Empresa Paulista de Planejamento Metropolitano S/A), com uma taxa de crescimento anual em torno de 1,29\% entre os anos de 2000/2010, uma das maiores do Estado de São Paulo, além de um PIB (Produto Interno Bruto) nacionalmente muito significativo.

\footnotetext{
${ }^{105}$ A Região Metropolitana do Vale do Paraíba e Litoral Norte (RMVPLN) é a quarta e maior região em território a ser constituída no Estado de São Paulo, que já conta com as Regiōes Metropolitanas de São Paulo (RMSP), Campinas (RMC) e Baixada Santista (RMBS).

Comparativo da densidade demográfica e Produto Interno Bruto entre as quatro regiōes metropolitanas do Estado de São Paulo:

- Densidade demográfica $\left(\mathrm{HAB} . / \mathrm{km}^{2}\right)$ :

RMSP: 2476 hab./km², RMC: 768 hab./km², RMBS: 686 hab. $/ \mathrm{km}^{2}$ e RMVPLN: 140 hab./km².

- $\quad$ Produto Interno Bruto - PIB de 2009:

RMSP: R \$ 613 bilhōes, RMC:R \$ 85,7 bilhōes, RMVPLN:R \$ 55,6 bilhōes e RMBS: R \$ 40 bilhōes.

Fonte: Região Metropolitana do Vale do Paraíba e Litoral Norte. Elaboração: Emplasa, VCP/UDI, 2012.
} 
A RMVP (Região Metropolitana do Vale do Paraíba e Litoral Norte) é composta por 39 municípios $^{106}$ e dividida em cinco sub-regiões (figura 87).

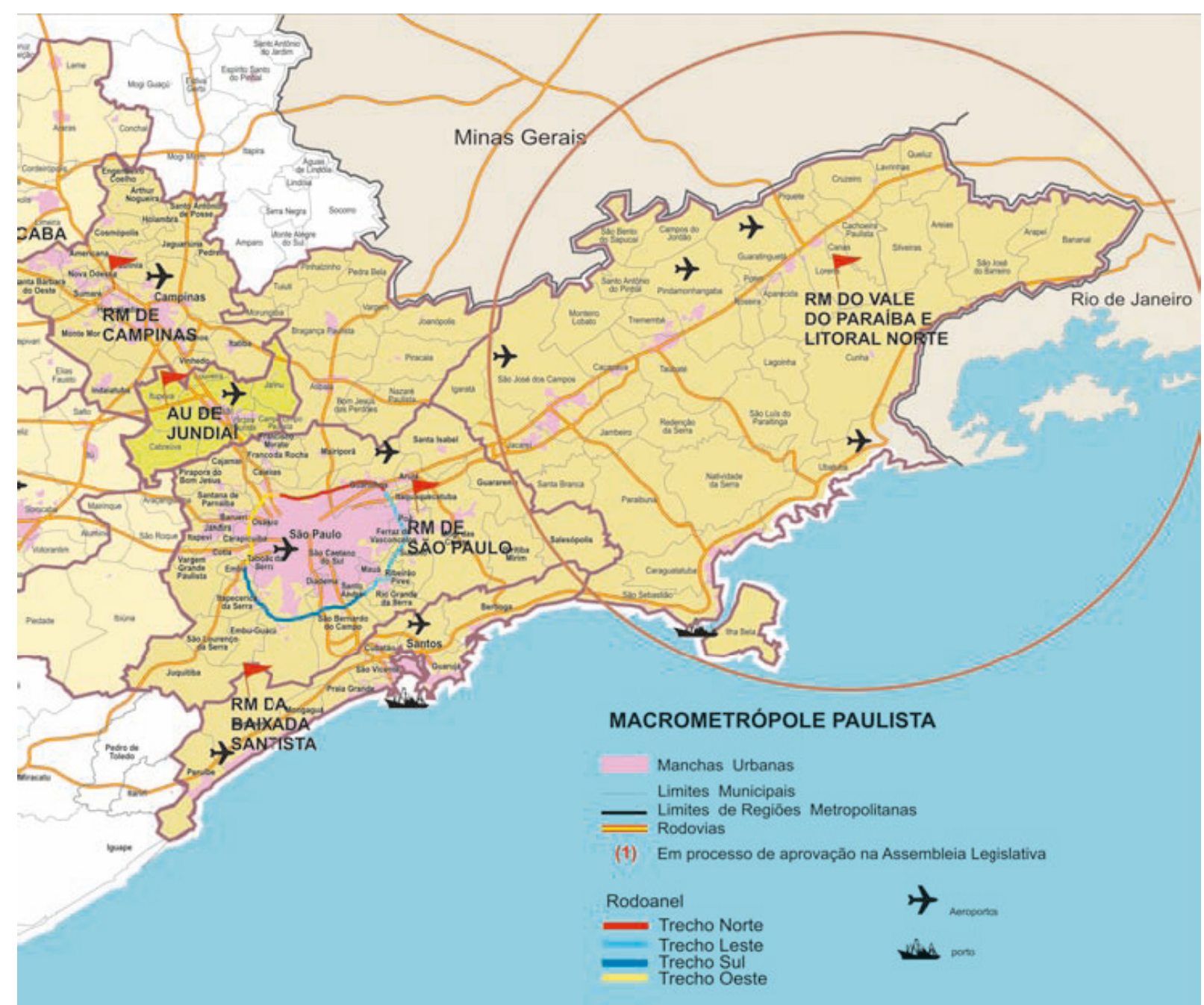

Fonte: Região Metropolitana do Vale do Paraíba e Litoral Norte. Elaboração: Emplasa, VCP/UDI, 2012.

Figura 85 - RMVP dentro do contexto da Macrometrópole

A sub-região 5 é o enfoque principal deste trabalho e está relacionada com a zona costeira do Litoral Norte do Estado de São Paulo, composta pelos municípios de Caraguatatuba, Ilhabela, São Sebastião e Ubatuba, com 479 quilômetros de extensão marítima e grande potencial turístico, principalmente pelo seu patrimônio natural, histórico, cultural e arquitetônico, mas também pelo interesse portuário

\footnotetext{
${ }^{106}$ RMVP (Região Metropolitana do Vale do Paraíba e Litoral Norte) é composta por 39 municípios e dividida em cinco sub-regiōes: 1 - Caçapava, Igaratá, Jacareí, Jambeiro, Monteiro Lobato, Paraibuna, Santa Branca e São José dos Campos.

2- Campos do Jordão, Lagoinha, Natividade da Serra, Pindamonhangaba, Redenção da Serra, Santo Antônio do Pinhal, São Bento do Sapucaí, São Luiz do Paraitinga, Taubaté e Tremembé.

3 - Aparecida, Cachoeira Paulista, Canas, Cunha, Guaratinguetá, Lorena, Piquete, Potim e Roseira.

4 - Arapeí, Areias, Bananal, Cruzeiro, Lavrinhas, Queluz, São José do Barreiro e Silveiras.

5 - Caraguatatuba, Ilhabela, São Sebastião e Ubatuba.
} 
onde já estão instalados o Terminal público Portuário de São Sebastião, administrado pela Companhia Docas de São Sebastião, e o Terminal Marítimo Almirante Barroso (Tebar), da Petrobras Transportes S/A - Transpetro, responsável principalmente pelo transporte de petróleo e seus derivados.

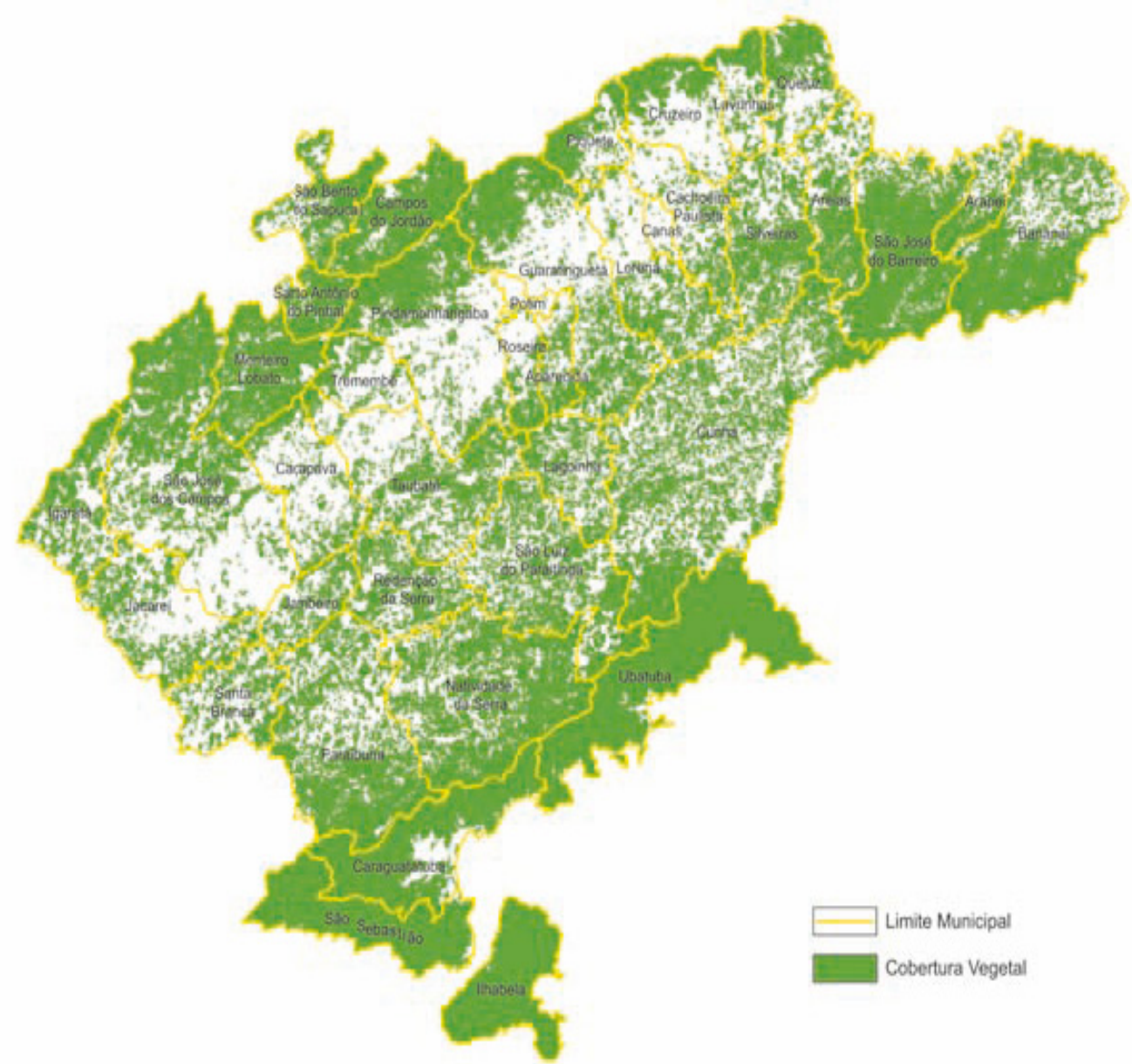

Fonte: Fundação Floresta, 2011. Elaboração: Emplasa VCP/UDI, 2012.

Figura 86 - Cobertura vegetal dentro da RMVPLN

Conforme já apresentado anteriormente, a maior facilidade de acesso ao litoral norte do Estado de São Paulo trouxe também grande interesse imobiliário, evidenciando a disputa pelo espaço, com construção de residências de veraneio na orla e, consequentemente, a de favelas nas encostas da Serra do Mar.

Um distanciamento socioespacial, principalmente por falta de um planejamento adequado e integrado o, que provocou o processo de valorização, ocupação predatória e irregular do solo, migração acelerada, distanciamento socioespacial e degradação ambiental, aprofundando o conflito de interesse entre os agentes sociais (setor imobiliário, proprietários dos meios de produção, proprietários fundiários, Estado e grupos sociais) fundamentalmente pela privilegiada configuração natural deste território. 


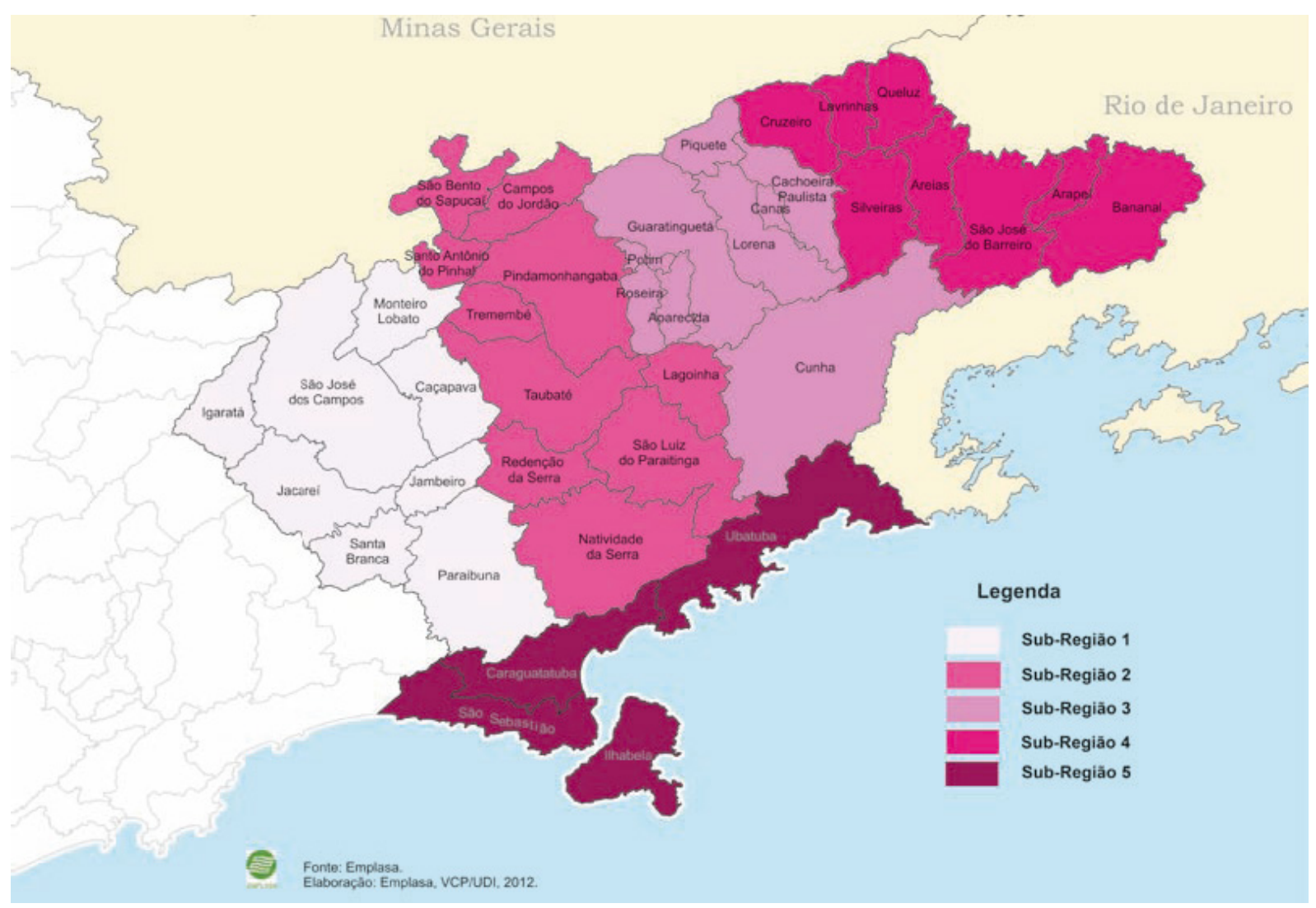

Fonte: Regiāo Metropolitana do Vale do Paraíba e Litoral Norte. Elaboração: Emplasa, VCP/UDI, 2012.

Figura 87 - Sub-regiões da RMVPLN - destaque para a sub-região 5 (Litoral Norte do Estado de São Paulo)

Entraremos em um novo ciclo econômico na sub-região 5, o que aprofundará ainda mais a disputa territorial, e os diversos empreendimentos em construção e em processo de licenciamento ambiental tendem a reforçar ainda mais a urbanização espraiada, agravando os problemas na região, principalmente o ambiental e urbano, com a ampliação do porto comercial e do píer da Petrobras, a duplicação das rodovias de acesso ao litoral (rodovia Doutor Manuel Hipólito Rego - SP-055, Contorno Norte e Sul e duplicação da rodovia dos Tamoios - SP-099) e a exploração da camada pré-sal na Bacia de Santos.

O crescimento econômico é necessário e desejável, mas falta um planejamento regional integrado para compatibilizar com antecedência os diversos interesses das cidades e ao mesmo tempo compreender a capacidade de suporte deste território litorâneo e suas especificidades

A recém criada Região Metropolitana do Vale do Paraíba e Litoral Norte - RMVPLN é o fórum oportuno para discussões mais amplas e integradas do desenvolvimento econômico da região. 


\subsection{Uma possibilidade para a zona costeira - território frágil ambientalmente}

$\mathrm{D}$ entro da RMVPLN existe a oportunidade de construir um sistema estruturador da zona costeira e auxiliar em um crescimento urbano mais equilibrado com os mesmos mecanismos e regras entre municípios para determinados assuntos, combatendo os inimigos comuns, como a especulação imobiliária, a ocupação acelerada e predatória, e, por outro, lado estimular a indústria do turismo, cujo interesse também é coletivo.

O desenvolvimento de um Plano Ambiental Econômico e Social ${ }^{107}$ para o Litoral Norte do Estado de São Paulo, através de uma empresa responsável pela gestão integrada e qualitativa da região, pode ser um dos caminhos. Uma empresa de capital social misto (público e privado de investidores), contando que a titularidade direta da maioria das ações com direito a voto para assuntos estratégicos e financeiros seja do poder público.

O Plano Ambiental levaria em consideração o arcabouço das políticas e legislações vigentes, bem como o diagnóstico dos diversos meios que compõe o sistema ambiental, através de um banco de dados (meio físico, meio biótico e meio socioeconômico) que viabilize as potencialidades da área e minimize os vetores de pressão sobre os atributos existentes, reduzindo os problemas de cunho socioambiental, fomentando atividades de desenvolvimento sustentável e valorização da diversidade socioambiental e cultural da população residente, além de viabilizar fóruns, reuniões públicas e debates para esclarecer os conceitos fundamentais dos novos empreendimentos na região, para anuência ou crítica de todos os agentes sociais pertinentes.

A região, além da análise ambiental, precisa ser avaliada em relação a sua capacidade de suporte, tanto no contexto metropolitano quanto local, para que suas especificidades sejam conduzidas a partir de um amplo processo de articulação dos diversos agentes sociais e econômico que interagem nesse território. Estas premissas visam garantir a adequação dos meios de utilização dos recursos naturais às especificidades do meio ambiente, tomando como base os princípios e diretrizes da sustentabilidade para promover a adequação e disciplinamento do uso e ocupação do solo.

A leitura crítica, matemática e analítica do território, com base nas características do meio físico e biótico, contribuirá na definição de um modelo ambiental sustentável, com equilibro econômico e ambiental, contemplando os diversos interesses com a definição de regras claras para o uso e ocupação do solo, compatíveis com a capacidade de suporte urbano e ambiental, orientando, assim, o modelo urbanístico das cidades dentro do contexto regional.

Conforme apresentado anteriormente, Peter Calthorpe e William Fulton, no livro The regional city, afirmam que o planejamento deve integrar, ao mesmo tempo, diversos elementos e demandas

${ }^{107}$ Com base na proposta apresentada para o Chamamento Público Arco do Tietê, em 2013, para Prefeitura Municipal de São Paulo. Disponível em: <http://gestaourbana.prefeitura.sp.gov.br/arquivos/arco_tiete/sumarios/ArcoTiete_Sumario_Magalhaes-Figueroa-ParkCapital-Pomar-JurandirRossi.pdf>. Acesso em: 15/12/2014. 
da ecologia, economia, história, política, legislação, cultura e estrutura social. Sem esta integração, os resultados são fragmentados, como metas e estratégias de implementaçôes difusas. Cada assunto é tratado de maneira isolada, e até de forma intencional, para evitar ou protelar colocar em prática mudanças necessárias e ainda manter pouca reponsabilidade com as implicaçôes na escala regional.

O planejamento regional é uma maneira de equilibrar os direitos individuais com as necessidades da comunidade. As políticas governamentais e a busca por recursos financeiros deveriam ter uma abordagem de sistemas inteiros.

A cidade regional tem mais a ver com a reparação e revitalização do ambiente urbano e suburbano existente do que com a criação de novos lugares, com destaque para melhoraria da qualidade de vida, através de centros interconectados e diversidade econômica.

Os conceitos de Milton Santos apresentado durante o seminário Território: globalização e fragmentação, em 1993, presentes no texto "O retorno do território", ajudam também a reforçar a importância da construção do espaço baseado nas relaçôes econômicas e sociais e do novo funcionamento do território através do que ele chamou de horizontalidades e verticalidades, onde a horizontalidade é o domínio da continuidade representada pelas cidades geograficamente próximas, e a verticalidade constitui uma relação com pontos distantes, uma conexão em rede, representadas pelas cidades mundiais. Estas questões possibilitam uma reflexão das características entre a horizontalidade, que é o espaço local, onde a utilização de seu território pode ser definida localmente e em benefício de sua própria população, e a verticalidade, que é o espaço global, determinado por regras e normas rígidas impostas a partir de lugares distantes e com benefícios igualmente distantes.

O trabalho demonstra que o conceito de horizontalidade definida por Milton Santos é uma das maneiras de justificar a importância da integração entre cidades vizinhas ou próximas geograficamente, fundamental para construir uma relação de poder e defender interesses próprios, além de viabilizar normas e benefícios locais.

Um plano regional de desenvolvimento, levando em consideração as potencialidades regionais, com clareza do que é comum e o que é complementar para cada local, pode ser uma garantia de sobrevivência em um mundo globalizado, onde as cidades tendem a buscar uma relação vertical entre si, o que para este território, ambientalmente vulnerável, seria um desastre.

As condiçôes naturais de São Sebastiāo (um dos melhores portos naturais do mundo), das ocupações existentes e projetadas, dos fluxos de mobilidade existentes e propostos, das políticas públicas, dos dados socioeconômicos em crescimento (região que mais cresceu no País), dos vetores de expansão urbana, demonstram a grande pressão urbana que este território, frágil ambientalmente, está sujeito.

Determinados assuntos deveriam ser tratados na escala regional sem fronteiras físicas ou políticas, com a implantação de ações de cooperação e de integração, com identificação de complementaridade e não de competitividade, para ampliar e diversificar as possibilidades de crescimento da 
região com distribuição equilibrada tanto dos benefícios quanto dos ônus provocados pelo desenvolvimento, como por exemplo:

- Entender que o emprego é uma atividade indutora.

- Redes de infraestrutura compatível e simultâneas com as novas demandas para que não se crie privilégios.

- Investir em alternativas econômicas para superar a sazonalidade.

- Evitar a segregação socioespacial e disciplinar o uso e ocupação do solo.

- Entender que o turismo é um "produto" comum entre municípios.

- Participação da população local nas discussões dos projetos propostos.

- A importância do espaço livre, do ativo natural e preservação de determinadas áreas.

- Sistema de transporte articulado entre municípios: o mar como via de circulação pública, principalmente no Canal de São Sebastião, com a real possibilidade de implantação de um transporte hidroviário que proporcione conexões entre os centros históricos das cidades e bairros da região - reforçará os acessos públicos com usos mais pertinentes das zonas costeiras e ainda poderá proporcionar um desenvolvimento da região através de uma gestão integrada, considerando a proteção e utilização de seus ativos naturais, principalmente o acesso público às frentes marítimas.

- Definição de critérios e regras regionais para a expansão urbana.

- Entender que a especulação imobiliária é um problema e deve ser combatida.

- Considerar que um desastre ambiental é cumulativo.

- Ampliação do Porto de São Sebastião para contêineres pode ser um problema e não uma solução.

- Definir áreas protegidas e preservadas com fiscalização permanente.

- Tratamento de esgotos e disposição dos resíduos sólidos.

- Proteção dos corpos d'água.

Portanto, determinados assuntos necessitariam serem aprofundados dentro de um entendimento muito mais amplo, que supere os limites físicos de cada município, e que oriente os planos diretores a alcançar objetivos comuns e regionais.

\subsection{0 instrumento EIA-RIMA pode ser otimizado?}

$\mathrm{O}$ s Termos de Referências (TR) que estabelecem os critérios e diretrizes utilizados na elaboração do EIA-RIMA poderão ser aprimorados, mais precisos, evitando estudos desnecessários, com participação efetiva dos técnicos dos diversos órgãos públicos para opinar.

Exigir através do TR maior ênfase aos assuntos polêmicos de um determinado empreendimen- 
to, com linguagem de fácil compressão e efetiva participação pública (bairro a bairro), em diversas fases dos estudos, considerando tempo hábil para contribuições, manifestações e questionamentos da sociedade civil organizada, também contribuirão em resultados mais confiáveis e pactuados ao longo do processo.

Em função da análise dos diversos EIA-RIMA em andamento no Litoral Norte do Estado de São Paulo, das pesquisas elaboradas, das fragilidades percebidas, apresentamos abaixo algumas sugestôes:

- Estudos de alternativas reais em relação ao local e sistemas construtivos do empreendimento, para comparar soluções.

- Estudos de Origem/Destino (OD), com simulação sobre a localização de atividades, uso do solo e transporte (carga e passageiro).

- Verificar efeitos das políticas e empreendimentos pretendidos para a cidade e região. Avaliá-los do ponto de vista social, econômico, financeiro, energético e ambiental, de forma sinergética.

- Garantir que na revisão dos planos diretores seja considerado estudos claros, que demonstrem a capacidade de suporte do território para absorver os impactos negativos causados pelo empreendimento a ser licenciado.

- Participação e formação efetiva da sociedade (bairro a bairro) em diversas fases do EIA, para que tenha capacidade real de influenciar e exigir novos rumos do projeto e/ou maiores contrapartidas.

- Ampliar e exigir maiores investimentos do empreendedor em parceria com as prefeituras e de forma antecipada nas infraestruturas urbanas, assumindo compromissos desde o EIA-RIMA.

- Licenças parciais serão renovadas com o cumprimento das metas definidas previamente dentro dos prazos estabelecidos, principalmente com a construção de forma antecipada das infraestruturas previstas ou necessárias para as novas demandas.

- Considerar estudos da emissão de $\mathrm{CO}^{2}$, efeito estufa e seu custo ambiental.

- Controle das novas fontes poluidoras para não repetir o caso da cidade de Cubatão, localizado no Litoral Sul do Estado de São Paulo, próximo ao porto comercial da cidade de Santos, onde foi instalado um grande polo industrial com o desmatamento de aproximadamente $60 \mathrm{~km}^{2}$ de Mata Atlântica. Considerada uma das regiōes mais ricas do Brasil, mas ao mesmo tempo uma das cidades mais poluídas do mundo, denominada "Vale da Morte" durante à década de 1980, pelos inúmeros problemas de saúde provocados em sua população, na fauna e flora. Foram necessárias décadas de investimentos e controle permanentes da emissão de poluição para recuperação ambiental. 
- Certificação verde ${ }^{108}$ para infraestruturas urbanas já poderiam ser consideradas como uma das solicitações dos EIA-RIMA como mais um dos pré-requisitos a ser exigido aos empreendimentos.

- Projetos para o desenvolvimento de sistemas energéticos autossuficientes, como, por exemplo, energia eólica e marés.

- Prever fases de implantação, comprovando metas atingidas para liberação das licenças das fases seguintes.

- Mitigações e compensação ambiental - são sempre mínimas -, ampliar os investimentos para efetivamente garantir sustentabilidade urbana

- Considerar a modelagem matemática para gerenciar a capacidade de suporte do território e auxiliar nos Estudos de Impacto Ambiental.

O Governo Federal e Estadual tem um papel ainda mais importante neste processo, investindo e exigindo de seus municípios planos diretores melhores e precisos, mais responsáveis e com efetiva participação pública. O Plano Diretor como um instrumento importante para condicionar e influenciar os Termos de Referência na elaboração de eventuais EIA-RIMA, necessários a empreendimentos de significativo impacto na região e como premissa, deve estar subordinado aos interesses públicos e da sociedade civil.

No livro Reinvente seu bairro: caminhos para você participar do planejamento de sua cidade, Candido Malta Campos Filho defende uma cidade plural, onde os conflitos sejam reduzidos, a qualidade ambiental seja melhorada e que haja progresso social.

O Plano de Bairro, de sua autoria, complementaria o Plano Diretor, que não chega nesta escala territorial. O plano pode ajudar o cidadão a perceber quais são os déficits de

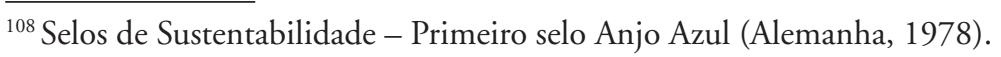

Atestar que determinada característica ambiental ou socioambiental de produtos, serviços e empreendimentos está de acordo com diretrizes estabelecidas por quem emite o selo, que demonstra seu desempenho e os esforços feitos para a redução do consumo de água, energia, $\mathrm{CO} 2$, matérias primas e melhor qualidade de vida. Para que seja considerado sustentável, deve também comprovar responsabilidade socioambiental. Principais Selos: Selo Procel (energia), Selo FSC (madeira de manejo sustentável) e Selo SustentaX (atesta produtos sustentáveis, construtoras, incorporadoras, eventos, escritórios de arquitetura e paisagismo, operadoras condominiais, prestadores de serviços, entre outros).

No Brasil, o principal selo verde para empreendimentos é o LEED - Leadership in Energy Environmental Design (fornecido pelo U.S. Green Building Council - conselho de construçôes verdes dos EUA), que levam em consideração principalmente os seguintes princípios:

- Reutilização e reciclagem de materiais e recursos.

- Espaço sustentável.

- Eficiência energética.

- Uso racional da água.

Inovação e tecnologia e atendimento a necessidades locais, definidas pelos próprios profissionais da GBC.

É o selo verde com maior reconhecimento internacional no setor da construção civil e atualmente o Brasil está em $4^{\circ}$ lugar no ranking da construção verde com cerificado LEED, ficando atrás apenas dos Emirados Árabes Unidos, China e EUA.
} 
infraestrutura, mas principalmente quais são os seus direitos para que, de forma participativa, contribua na melhoraria da qualidade de vida de seu bairro e da cidade como um todo.

De acordo com o arquiteto Candido Malta Campos Filho, o Plano de Bairro diminuiria a discrepância atual entre o padrão de consumo e o padrão de urbanismo, e ainda melhoraria a ideia de que o planejamento urbano viabiliza apenas obras de interesse dos empreiteiros. 


\section{CAPÍTULOX}

SimULADORES URBANOS

Capacidade de suporte do território 


\subsection{Capacidade de suporte do território}

$\Lambda_{\text {cos serem utilizados como ferramentas complementares aos Estudos de Impacto Ambiental }}^{\text {intence capitulo é colocar em discussão a possibilidade dos simuladores matemáti- }}$ (EIA-RIMA), com o objetivo de atingir resultados mais sustentáveis no desenvolvimento urbano de nossas cidades.

Para verificar a capacidade de suporte do território com embasamento científico, existem softwares, cuja principal característica é simular e gerenciar os possíveis cenários em função da base de dados inseridas no sistema.

São instrumentos com grande potencial para auxiliar no planejamento e gestão das cidades, principalmente em função da relação entre uso e ocupação do solo e os meios de transportes. Permitem simulações dos prováveis efeitos das políticas públicas e projetos, nos aspectos sociais, econômicos, financeiros, energéticos e ambientais, tanto na escala das cidades quando na região.

Mostra que dependendo dos dados inseridos no sistema e de sua calibragem, os cenários serão diferentes, ou seja, escolhas podem ser feitas de forma a simular o futuro e conhecer previamente os problemas para antecipar soluçoes. Temos, então, as ferramentas para definir hoje o cenário mais adequado e suficiente, com capacidade de controlar os aspectos negativos, corrigir rumos, caso necessário, com o objetivo de alcançar a hipótese previamente definida. Quantificar através dos simuladores matemáticos é uma das maneiras de conhecer hoje o futuro de nossas cidades.

O Tranus - Integrated Land Use and Transport Modeling System (Sistema Integrado de Simulação da Localização das Atividades, Usos do Solo e Transportes), desenvolvido por Tomas de la Barra entre outros pesquisadores na Universidade de Cambridge, na década de 1970, é até hoje um dos simuladores urbanos mais importantes e gratuito utilizado no mundo.

Simula a curto, médio e longo prazo os prováveis efeitos de políticas de uso do solo e de transporte e avalia os efeitos sociais, econômicos e ambientais. Considera que a localização das atividades no espaço estão diretamente relacionadas ao uso do solo e aos sistemas de transportes. Estimativas no campo dos transportes envolvem inclusive a multimodalidade e engloba todos os aspectos relacionados ao uso do solo. 
Integra os diversos dados do sistema urbano e regional para compreender como o acesso aos meios de transporte, circulação de pessoas e mercadorias no território afetam a ocupação, as relações econômicas e o setor imobiliário.

A aplicação do modelo TRANUS na estimativa de uma matriz Origem/Destino (OD) de cargas, por exemplo, necessita do conhecimento de diversas variáveis e parâmetros para que este estudo seja o mais fiel possível e consiga orientar os planos de desenvolvimento, seja local ou regional. Podem e devem contribuir também com os planos de urbanização, estudos de impacto ambiental, controle sobre os usos do solo, novas instalaçôes ou adequações portuárias e aeroportuárias, entre outras modelagens. ${ }^{109}$

Os resultados são científicos e incontestáveis, o que poderíamos considerar como suporte fundamental aos estudos de impacto ambiental.

Teríamos a capacidade para simular diferente cenários em função das informações e da calibragem inseridas no sistema, e assim conhecer se a alternativa pretendida é compatível ambientalmente e até mesmo quais os investimentos necessários para um meio urbano mais sustentável. É possível conhecer os efeitos imediatos de um novo empreendimento, como a duplicação ou construção de uma nova rodovia, por exemplo, e ao mesmo tempo ter informaçôes dos impactos mais importantes no uso e ocupação do solo a médio e longo prazo.

É claro que muitos dos resultados não agradarão o empreendedor ou até mesmo o próprio poder público, que serão obrigados a maiores investimentos, muitos deles imediatos, em infraestruturas de mobilidade, saneamento básico, habitação de interesse social, postos de saúde, escolas, creches, entre outros equipamentos. Evidentemente, diminuiria as margens de lucro do setor privado e dificultaria a implantação de empreendimentos ou atividades geradoras de impactos ambientais que não tenham maiores compromissos com a sustentabilidade urbana.

${ }^{109}$ TRANUS - principais características das modelagens matemáticas deste software:

- Modelo locacional de atividade e simulação do mercado imobiliário.

- Representação detalhada do transporte público.

- Estimativas econômica, financeira e ambiental.

- Detalhamento urbano, regional e nacional.

- Orientar políticas públicas com a matriz Origem/Destino (OD).

- Verificar o impacto de projetos industriais ou residenciais.

- Planos e estímulos para a construção de moradias.

- Proteção do meio ambiente através do controle sobre as áreas especiais.

- Verifica a necessidade de:

- Novas estradas e melhoria das estradas existentes.

- Reorganização do sistema de transporte público (novas rotas e tarifas).

- Sistemas de transporte coletivo com tarifas integradas e faixas exclusivas de ônibus.

- Rodovias de pedágio urbanas ou regionais.

- Faixas exclusivas para transporte público e restrições à circulação de veículos.

- Projetos ferroviários. 
Enfim, os simuladores matemáticos ${ }^{110}$ são ferramentas poderosas para auxiliar o planejamento urbano e regional, e contribuir cientificamente no entendimento cumulativo e sinergético dos grandes empreendimentos em andamento no Litoral Norte de São Paulo. Portanto, uma maneira de conhecimento das novas demandas e, consequentemente, fonte de informação do que deve ser feito hoje para que os sistemas não entrem em colapso amanhã.

\footnotetext{
${ }^{110}$ Outros programas também reconhecidos como importantes simuladores matemáticos: Absolute (Activity-Based System of Land Use and Transport Events): simula alteraçôes nos padrōes de uso do solo, padrões de viagens e atividades, e resulta em modelagens que podem auxiliar nas decisóes governamentais para o uso do solo, bem como para localização de empresas e habitações. Integra demanda por transporte, baseado em atividades ao uso do solo. Ilumass (Integrated Land-Use Modelling And Transportation System Simulation): simula o fluxo de tráfego urbano na escala local (gera padrōes de mobilidade individual) e incorpora alteraçôes no uso do solo e da demanda por transporte. Meplan (Marcial Echenique): simula a demanda por transporte e o crescimento das atividades produtivas. O objetivo é calcular o equilíbrio entre a demanda por viagens de passageiros e de cargas, a oferta de transporte e a localização espacial das atividades econômicas. Permite análises e avaliações de projetos estratégicos de infraestrutura.
} 
CAPÍTULO XI

Conclusão 
$\mathrm{O}$ amanhã será catastrófico para as cidades que ainda não compreenderam a importância de incluir de maneira responsável e na prática os conceitos de sustentabilidade ambiental e urbana em seu desenvolvimento econômico

Em relação ao Litoral Norte do Estado de São Paulo podemos afirmar que não existe um planejamento urbano e regional pensados e espacializados de forma conjunta, fruto de pesquisas científicas e com consultas públicas, para orientar os planos diretores dos municípios que compõe a região e que sirvam como documento para alcançar objetivos sustentáveis previamente definidos.

Decidir por um modelo mais equilibrado de desenvolvimento faz parte de um embate e negociação política, principalmente de como distribuir as riquezas. Portanto, é fundamental um prévio planejamento regional, para definir parâmetros e regras com ênfase na sustentabilidade urbana, e uma gestão integrada deste desenvolvimento. Será necessário um pacto político em nome da sustentabilidade, que contemple as dimensões social, ambiental, econômica, política e cultural, caso contrário este objetivo jamais será alcançado.

Os dados do IBGE ${ }^{111}$ informam que, dos 76 municípios com mais de 100 mil habitantes do Estado de São Paulo, o município de Caraguatatuba foi considerado em 2013 e pelo terceiro ano consecutivo como o mais violento do Estado, com taxa de 28,3 homicídios por 100 mil habitantes, o triplo do índice de todo o Estado, o que demostra o desequilíbrio em andamento na região. Outros estudos também demonstram que o saneamento básico é precário e piora muito nos períodos de alta temporada, com o acréscimo da população flutuante, que dobra o número de pessoas no litoral, agravando ainda mais o abastecimento de água, coleta de lixo, esgotamento sanitário na região e piorando os índices de contaminação das praias e das águas, apesar do Programa Onda Limpa, criado em 2007 pelo Governo do Estado de São Paulo para minimizar o problema.

Segundo dados do IBGE, CETESB e da própria Prefeitura Municipal de São Sebastião, o crescimento dos indicadores negativos demostram os problemas causados pela pressão demográfica, com o aumento de praias impróprias (seis praias impróprias em 1991, contra 19 praias impróprias em 2008) e o aumento de favelas (de 5 mil no ano de 2001 para 22 mil em 2011). Outro dado importante a ser considerado é que atualmente o lixo produzido por São Sebastião, Ilhabela, Cara-

${ }^{111}$ Fonte: IBGE (Instituto Brasileiro de Geografia e Estatística) e SSP-SP (Secretaria da Segurança Pública do Estado de São Paulo). 
guatatuba e Ubatuba é enviado para a cidade de Tremembé, a aproximadamente 150 quilômetros do litoral norte, e com um custo de R \$ 50 milhões no ano de 2014 (São Sebastião gasta R 22 milhões, Ubatuba $\mathrm{R}$ \$ 14 milhões, Caraguatatuba $\mathrm{R}$ \$ 9,6 milhões e Ilhabela $\mathrm{R}$ \$ 4,7 milhões para coletar e transportar o lixo, até o aterro localizado no Vale do Paraíba). ${ }^{112}$

Recentemente, um empreendedor tentou licenciar um projeto para a construção de um aterro sanitário no município de Caraguatatuba. As licenças ambientais foram negadas pela Companhia de Tecnologia de Saneamento Ambiental (CETESB), respeitando decisão do Conselho de Defesa do Patrimônio Histórico, Arqueológico, Artístico e Turístico (Condephaat), que não aprovou o local pretendido, por considerar a região de planície, com características arenosa, próxima a áreas protegidas ${ }^{113}$ e com grande possibilidade de alagamento, o que mais uma vez comprova as especificidades e fragilidades ambientais da região.

No município de São Sebastião, os diversos empreendimentos e atividades considerados por lei de significativo impacto ambiental, licenciados ou em processo de licenciamento, apresentam fortes indícios de que os Estudos de Impacto Ambiental e seus respectivos Relatórios de Impacto Ambiental (EIA-RIMA) são insuficientes enquanto busca de sustentabilidade urbana, conforme evidências já apresentadas neste trabalho, a começar pelo Artigo $8^{\circ}$ da Resolução Conama no 001, de 23/01/1986, na qual estabelece que todas as despesas e custos referentes à realização do Estudo de Impacto Ambiental (EIA), tais como coleta e aquisição dos dados e informações, trabalhos e inspeçôes de campo, análises de laboratório, estudos técnicos e científicos, acompanhamento e monitoramento dos impactos e elaboração do RIMA. Podemos pensar que, desta forma, existem condiçõos propícias para que os resultados sejam manipulados, já que o maior interessado pela aprovação dos EIA-RIMA é o próprio empreendedor. Há também a expectativa de que os estudos indiquem investimentos mínimos para eventuais mitigações e ou compensações ambientais.

A Resolução Federal do Conselho Nacional do Meio Ambiente, CONAMA 001/86, através da Política Nacional de Meio Ambiente, instituída em 1981 pela Lei 6938/81, estabelece os procedimentos, critérios e diretrizes gerais para a elaboração dos Estudos de Impacto Ambiental (EIA) e respectivo Relatório de Impacto Ambiental (RIMA), e solicita medidas mitigadoras dos impactos negativos e monitoramento constante dos impactos positivos e negativos.

O conceito de mitigação está relacionado a diminuir ou reduzir o dano do empreendimento ou da atividade poluidora, e o próprio EIA-RIMA apresenta quais serão estas medidas. Naturalmente, o estudo condicionará medidas mínimas para as mitigações já que o empreendedor estará disposto a investir o mínimo também nas diversas fase do projeto.

\footnotetext{
${ }^{112}$ G1 Vale do Paraíba. Disponível em: <http://g1.globo.com/sp/vale-do-paraiba-regiao/noticia/2014/02/cetesb-neganovo-pedido-para-instalacao-de-aterro-no-litoral-norte.htm>. Acesso em: 12/02/2014.

${ }^{113}$ G1 Vale do Paraíba. Disponível em: <http://g1.globo.com/sp/vale-do-paraiba-regiao/noticia/2014/02/cetesb-neganovo-pedido-para-instalacao-de-aterro-no-litoral-norte.htm>. Acesso em: 25/08/2014.
} 
Os EIA não consideram de forma importante em seus estudos os serviços ambientais prestados por determinadas áreas impactadas, e muito menos o cálculo de emissóes de gás carbônico e eventuais mudanças climáticas. São estudos que devem ser traduzidos em ameaças e somados aos importantes impactos causados pelo empreendimento a ser licenciado. Se não houver pressão constante, principalmente da sociedade civil organizada, já que por muitas vezes o Estado representa e/ ou apoia os interesses privados, as perdas serão muito maiores para a coletividade do que os ganhos indicados pelo EIA-RIMA.

\subsection{Como compensar ou mensurar um dano ambiental considerado irreversível?}

$\mathrm{O}$ licenciamento ambiental de empreendimentos considerado pelo órgão ambiental de significativo impacto ambiental no Art. 36, da Lei no 9.985 de 18/07/2000, instituiu o Sistema Nacional de Unidades de Conservação da Natureza (SNUC), que baseado em estudo de impacto ambiental e respectivo relatório (EIA/RIMA), informava que o empreendedor era obrigado a apoiar, implantar e manter unidades de conservação do Grupo de Proteção Integral e investir a partir de $0,5 \%$ do valor do empreendimento a ser fixado pelo órgão ambiental licenciador, de acordo com o grau de impacto ambiental causado pelo empreendimento.

O Decreto 4.340/02, em conjunto com o Decreto 6.848/09, regulamentou os critérios para compensação ambiental ${ }^{114} \mathrm{e}$ alterou para baixo os valores dos recursos destinados pelo empreendedor para compensar ou mitigar os impactos ambientais causados nos ecossistemas e definidos pelo EIA-RIMA.

A alteração foi diminuir o montante de recursos a ser destinado pelo empreendedor e estabeleceu valores entre 0 a $0,5 \%$ do total previstos para a implantação do empreendimento.

A lei estabelece um valor máximo para as compensaçôes ambientais e impactos negativos, o que reforça ainda mais a ideia de um pacto em torno do mínimo e insuficiente enquanto busca de sustentabilidade urbana.

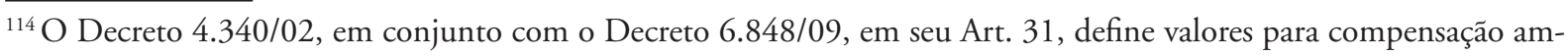
biental baseado nos impactos negativos causados ao meio ambiente e definidos pelo EIA-RIMA.

O IBAMA é responsável por calcular o valor da compensação ambiental e definir sua destinação, através da fórmula $\mathrm{CA}=\mathrm{VR} \times \mathrm{GI}$.

$\mathrm{CA}=$ Valor da Compensação Ambiental;

$\mathrm{VR}$ = somatório dos investimentos necessários para implantação do empreendimento;

$\mathrm{GI}=$ Grau de Impacto nos ecossistemas, podendo atingir valores de 0 a $0,5 \%$ do valor do empreendimento.

Cálculo do GI = ISB CAP IUC (confirmar se é multiplicado ou somado)

ISB = Impacto sobre a Biodiversidade (O ISB terá seu valor variando entre 0 e 0,25\%).

$\mathrm{CAP}=$ Comprometimento de Área Prioritária (O CAP terá seu valor variando entre 0 e 0,25\%).

IUC = Influência em Unidades de Conservação (Pode variar de 0 a 0,15\%).
} 


\subsection{Insuficiência dos Estudos de Impactos Ambientais na cidade de São Sebastião en- quanto busca de sustentabilidade urbana}

C onforme já detalhado anteriormente, o aterro em frente ao centro histórico foi resultado de uma negociação entre Petrobras e Governo do Estado. Segundo o EIA-RIMA, elaborado pela HIDROSERVICE em março de 1987 (após o início das obras), os novos aterros hidráulicos não causariam nenhum tipo de impactos negativos no meio biológico, socioeconômico e físico da região e no patrimônio histórico da cidade.

O relatório considerava ainda que as obras seriam responsáveis pelos benefícios socioeconômicos locais e regionais para a cidade, que ganharia novas áreas de lazer, já que, segundo o relatório, São Sebastião não possuía espaço para futuras ampliações da malha urbana, portanto, uma grande oportunidade. Hoje podemos comprovar que o espaço gerado a partir do aterro impactou negativamente pelo simples fato de ficar por mais de duas décadas sem nenhuma definição concreta de sua utilização.

$\mathrm{O}$ aterro ficou por mais de 23 anos abandonado ou sendo utilizado de forma eventual, principalmente para eventos musicais, atividades com pouco retorno econômico para cidade e grande impacto em sua infraestrutura, além da alteração de uma das mais importantes características do centro histórico de São Sebastião, que era sua proximidade física e conexão com o mar. Hoje, a linha d'água está a mais de 200 metros de distância da sua posição original, alterando a paisagem cênica e histórica da cidade. $\mathrm{O}$ aterro, com aproximadamente $65.000 \mathrm{~m}^{2}$, resultou em áreas ambientalmente modificadas, com baixa qualidade do subsolo.

Somente em 2009 é que foram iniciadas as obras de urbanização do aterro, com usos no mínimo discutíveis, como por exemplo concha acústica, arborização (bosque e calçadas), espaço zen (meditação), bosque para piquenique, arvorismo mirim, observatório ambiental, playground lúdico musical, playground para idoso, quadra de tênis, sanitários, entre outros usos duvidosos para este setor da cidade.

Em levantamento efetuado em dezembro de 2014, período de férias, verificamos que a avenida Dr. Altino Arantes, mais conhecida como Rua da Praia, que por sinal desde o ano 1980 não tem mais nenhuma relação com o mar ou praia, estão localizados aproximadamente 33 imóveis, grande parte destinados às sorveterias e restaurantes, mas que na sua maioria abrem apenas no horário noturno, o mesmo caso do aterro "urbanizado", que também permanece grande parte do tempo ocioso.

Muitos restaurantes típicos fecharam suas portas nestes últimos 20 anos e diversos imóveis foram desocupados, como, por exemplo, o antigo edifício colonial Hotel da Praia e a Casa Esperança, ${ }^{115}$

\footnotetext{
${ }^{115}$ Tombado em 1955 pelo IPHAN (Instituto do Patrimônio Histórico e Artístico Nacional).
} 
edifício tombados em 1969 pelo Condephaat (Conselho de Defesa do Patrimônio Histórico, Artístico, Arquitetônico e Turístico do Estado).

O perfil do comércio mudou e alterou suas especificidades locais para uma configuração mais genérica e de baixa qualidade, fazendo com que a cidade de São Sebastião perdesse seu caráter de centro do município e consequentemente sua identidade.

Analisando o EIA-RIMA da ampliação do porto comercial de São Sebastião, denominado Porto Integrado Porto-Cidade (PIPC), podemos concluir que as preocupações em relação à integração do porto com a cidade estão muito mais no nome dos estudos do que em propostas efetivas para atingir este objetivo. Não existe sequer uma zona de amortecimento entre porto e cidade, apenas um muro de separação.

O estudo ainda sugere como medida mitigatória, a fim de melhorar a relação porto-cidade, que o muro seja substituído por grades.

Outro estudo que não foi considerado em nenhum dos EIA-RIMA são os testes de laboratório para compreender as obras náuticas, como a ampliação do porto, o novo píer da Petrobras e futuras marinas.

O entendimento das ondas, ventos, correntes marítimas, marés altas e baixas e outras informações são fundamentais para comprovar se as infraestruturas projetadas dentro d'água são adequadas. Para um projeto correto é necessário entender a frequência e forma das ondas, ${ }^{116}$ além do efeito dos ventos sobre elas.

As características das ondas, suas oscilaçōes, frequências e ressonâncias, são informações que influem no desenho das proteçôes e dos quebra-ondas, além de indicar os locais mais adequados aos atenuadores e ancoradouros para as amarras das embarcações.

No laboratório, o projeto vai sendo alterado e corrigido em função dos testes e das diversas simulações necessárias, a fim de não existir erros. A solução final tem o objetivo de respeitar ao máximo o funcionamento natural dos sistemas ambientais.

Os modelos dos testes hidráulicos são elaborados através de maquetes, ${ }^{117}$ com as informações do projeto a ser construído, para simular com grande precisão o seu funcionamento em função dos movimentos das marés e dos ventos e compreender:

- Energia, periodicidade e direções.

- Trânsito das embarcações dentro do Canal de São Sebastião e a influência destas osci-

\footnotetext{
${ }^{116}$ É necessário levar em consideração ondas que ocorrem longe das próprias construções, e que podem influir diretamente em seu funcionamento.

${ }^{117}$ Os modelos de laboratório são construídos em tanques, usando as escalas entre 1:60 a 1:120 para os projetos, que reproduzem todos os detalhes existentes, como profundidades, quebra-ondas e outros elementos importantes, para serem submetidos a diversas simulações. O objetivo é observar e obter todas as informações possíveis de como as energias das ondas e ventos vão se dissipar e quais as novas direçôes tomadas. As investigações indicam onde estão os problemas e contribuem para as devidas correções, minimizando os efeitos climáticos nas novas instalações.
} 
lações nos quebra-ondas e ancoradouros.

- Consequências e influências do mau tempo nos ancoradouros e o impacto sobre as proteções em diferentes situações climáticas.

A seguir são apresentadas outras ameaças que não foram consideradas de forma aprofundada e evidências da falta de sustentabilidade que a região está sujeita:

- O porto é um equipamento estruturante e com sua ampliação certamente atrairá para região novas indústrias e consequentemente maiores níveis de poluição.

- Transportadoras buscando novos terrenos para estocar mais contêineres.

- Estacionamento de caminhôes fora do setor portuário.

- Escoamento apenas por caminhões, com estimativa de 750 caminhões por hora.

- Novos e constantes congestionamentos nas estradas e no acesso ao porto.

- Maiores dificuldades para acessar o município de Ilhabela.

- O porto vai avançar sobre o centro histórico e áreas ambientalmente frágeis.

- Favelização com ampliação dos aglomerados de baixa renda na região.

- Ampliação de possíveis vazamentos e grandes desastres ambientais.

- Maior pressão na Mata Atlântica.

- Comprometimento da biodiversidade e degradação dos recursos naturais.

- Ocupação do manguezal do Araçá - presta importantes serviços ambientais.

- Novo terminal para meganavios ampliando o congestionamento náutico.

- Impacto negativo no turismo.

- Impacto negativo no ambiente e paisagem.

- Falta de infraestrutura compatível e simultânea para as novas demandas.

- São Sebastião perde a cada dia seu status de cidade central.

- Disseminação de condomínios e loteamentos fechados.

- Maior número de praia impróprias para o banho.

- Maior produção de lixo, entulho e esgoto não tratado.

- Substituição da vegetação nativa por espécies exóticas.

- Dispersão urbana com o consumo extensivo do território e dos recursos naturais.

\subsection{Faltam estudos com visão global}

tualmente não existe nenhum estudo com visão global dos EIA-RIMA em andamento no
Litoral Norte do Estado de Paulo. Falta o entendimento cumulativos e sinergéticos entre os projetos considerados de grande impacto no ambiente, como a ampliação do porto e píer da Petrobras, duplicação da rodovia dos Tamoios, construção do Contorno Sul e Norte, duplicação 
da rodovia Dr. Manoel Hyppolito do Rego - SP-055, exploração da camada pré-sal, Unidade de Tratamento de Gás de Caraguatatuba - UTGCA, entre outras infraestruturas.

A ausência de compreensão científica da capacidade de suporte integrada da região ampliará o desconhecimento dos efeitos negativos e será responsável pelo catastrófico cenário urbano e ambiental, que iremos presenciar a curto e médio prazo. Por isso, a população precisa se manifestar e adquirir capacidade real de influenciar no destino de nossas cidades.

Hoje, a participação da comunidade nas audiências públicas, onde os estudos ambientais destes empreendimentos são apresentados, tem pouco a contribuir com as discussão e encaminhamentos dos estudos, já que as decisões mais relevantes já estão tomadas.

Conforme apresentado anteriormente, é comum que o Ministério Público (MP), depois de todo o processo de aprovação e das licenças já expedidas pelo órgão licenciador autorizando o empreendimento, abra um processo para suspender tais licenças. Foi o caso da ampliação do porto de São Sebastiāo, que teve sua Licença Prévia (LP) autorizada pelo IBAMA em 2013 e cassada em 2014, através do processo 0000398-59.2014.4.03.6135, Suspensão LP - Licença Prévia do Porto de São Sebastião.

Uma ação civil pública, ajuizada pelo Ministério Público Federal e Ministério Público do Estado de São Paulo contra o Instituto Brasileiro do Meio Ambiente e Recursos Naturais Renováveis IBAMA e Companhia Docas de São Sebastião - CDSS, invalidou a licença prévia no. 477/13 da ampliação do Porto de São Sebastião, considerando a ausência de estudos de impacto cumulativos e sinergéticos dos empreendimentos localizados na região, incorreta definição das áreas de influência direta e indireta, ausência de avaliação devida dos planos e programas governamentais propostos e em implantação da área de influência do projeto e sua compatibilidade e ausência de reais alternativas locacionais.

O IBAMA, por sua vez, contestou os itens acima descritos, alegando que a Resolução CONAMA no 01/86 não exige análise aprofundada dos impactos cumulativos e sinergéticos do empreendimento e que as informações fornecidas pelo empreendedor atendem a resolução. Afirma que foi correta a definição das áreas de influência direta e indireta do empreendimento, e que está em conformidade com a legislação municipal de uso e ocupação do solo e por ser obra de utilidade pública não está sujeita às regras do Zoneamento Ecológico Econômico do Litoral Norte.

Considera também que foram observadas alternativas locacionais e tecnológicas para o empreendimento, e que o Art. $8^{\circ}$ do novo Código Florestal não veda a intervenção ou supressão de manguezal em caso de obra de utilidade pública, como, por exemplo, o local determinado para a ampliação do Porto de São Sebastiāo, o manguezal do Araçá, o que o isentaria de atender todas as legislações anteriores.

Os Estudos de Impacto Ambiental invariavelmente finalizam seus trabalhos afirmando que a equipe responsável considera o projeto em análise ambientalmente viável, desde que sejam adotadas 
todas as medidas, sugestões e recomendações propostas e que muitos dos componentes ambientais afetados negativamente serão apenas de forma temporária e reversível, e que os impactos negativos permanentes, por sua vez, serão de intensidade reduzida, não comprometendo de maneira significativa a qualidade ambiental da área de influência, ou seja, jamais o próprio contratante imagina receber como conclusão do trabalho que contratou o resultado de que seu empreendimento é inviável.

Interesses econômicos do setor privado, além dos grupos que se encontram no poder, acabam facilitando o andamento e os processos de licenciamentos ambientais. Apesar dos diversos instrumentos legais de proteção ambiental, a definição final é na maioria das vezes um componente fundamentalmente político, influenciado principalmente pelo interesse dos grupos hegemônicos. O quanto do território será utilizado de forma consciente e sustentável, ou preservado, dependerá muito mais da mobilização e pressão social com conscientização política e ambiental do que contar apenas com os esforços públicos.

O instrumento de licenciamento ambiental EIA-RIMA precisa ser aprimorado para maior suficiência enquanto busca de sustentabilidade urbana, onde os compromissos assumidos nos estudos também sejam mais significativos e dependam menos das manobras políticas. Para alimentar os debates, algumas considerações:

- Incluir nos EIA-RIMA a exigência de estudos matemáticos e simuladores urbanos, relacionados à capacidade de suporte, para compreender e discutir com diversos setores da sociedade, mas principalmente com a opinião pública os prováveis cenários do empreendimento.

- O empreendedor transfere a uma empresa constituída dentro da Região Metropolitana do Vale do Paraíba e Litoral Norte - RMVPLN o valor das custas do EIA-RIMA, que será responsável por organizar e conduzir todo o processo de licenciamento, desde a escolha dos responsáveis pela elaboração dos estudos até as audiências públicas, ou seja, o cliente passa a ser o poder público e não o próprio empreendedor.

- Maior qualificação dos técnicos responsáveis pela análise do EIA-RIMA dentro do órgão licenciador e garantias que o mesmo técnico responsável pelas análises de um determinado EIA-RIMA mantenha seu parecer frente às pressões políticas.

- Conselhos gestores das unidades de conservação precisam possuir poder deliberativo e não apenas consultivo.

- Participação pública efetiva e em diversas etapas do processo com capacidade de influir e contribuir substancialmente nos trabalhos.

- EIA-RIMA mais objetivo e focado nos assuntos fundamentais e mais polêmicos, com linguagem de fácil acesso à população.

- Estudos técnicos e principalmente propostas de mitigação e/ou compensação ambiental menos subjetivas, dando margem a interpretações diversas. 
- Região Metropolitana do Vale do Paraíba e Litoral Norte: colocar em prática a Avaliação Ambiental Estratégica (AAE) como instrumento para antecipar e promover a articulação das várias dimensões de um programa de desenvolvimento para a região, com visão abrangente e sequencial dos impactos ambientais, o que auxiliaria na viabilização econômica, social e ambiental e na formulação de políticas e planejamento integrado, ajudando ainda na avaliação de impactos cumulativos e consequentemente melhorando os resultados dos EIA-RIMA individuais.

- Desenvolvimento de pesquisas científicas e um banco de dados da RMVPLN, com pesquisas constantes da região em relação ao meio físico, biótico e socioeconômico.

- Utilizar a Lei no 13.089, de 12/01/2015 - Estatuto da Metrópole, para auxiliar no planejamento, gestão e execução das funções públicas de interesse comum na Região Metropolitana do Vale do Paraíba e Litoral Norte - RMVPLN.

A costa brasileira, com seus inúmeros recursos e produtos naturais, sua condição climática, com poucas variações de temperatura ao longo das diversas estações do ano e as extensas águas navegáveis, proporcionam uma situação adequada para a ampliação e exploração deste potencial, e é o que está em curso na cidade de São Sebastião.

Será necessário estabelecer regras claras de utilização desta interface entre o território terrestre e marinho. São áreas de grande interesse econômico, mas ao mesmo tempo frágeis ambientalmente, onde o domínio público deverá ser uma prioridade e a especulação imobiliária combatida.

Para proporcionar um desenvolvimento regional equilibrado, será fundamental compreender muito além das questôes relacionadas apenas com a preservação dos recursos naturais. Será necessário um embate político, com ênfase na função social da terra, e participação efetiva de uma sociedade civil mais informada, mais preparada e organizada para subsidiar novas e qualificadas discussões, com condições de exigir o planejamento integrado de uma região e estudos de impacto ambientais mais precisos com contrapartidas muito maiores, tanto do setor público quanto do setor privado, para que sejam suficientes e eficientes enquanto busca da sustentabilidade urbana. 


\section{Bibliográficas}

AB'SÁBER, Aziz Nacib. Litoral do Brasil. São Paulo: Editora Metalivros, 2001.

ACIOLY, C.; DAVIDSON, F. Densidade urbana: um instrumento de planejamento e gestão urbana. Rio de Janeiro: Mauad, 1998.

ADIE, Donald W. Marinas: a working guide to their development and design. Londres/ Boston: Architectural Press/ Cahners Books, 1975.

AMARAL, Ricardo. Cruzeiros marítimos. São Paulo: Editora Manole, 2002

BENTLEY, I. et al. Entornos vitales: hacia un diseño urbano y arquitectónico más humano manual práctico. Barcelona: Gustavo Gili, 1999.

BOHIGAS, Oriel; BUCHANAN, Peter e LAMPUGNANI, Vittorio M. Barcelona: city and architecture 1980 -1992. Barcelona: Ed. Gustavo Gili, S.A.,1991.

CAIRNCROSS, Frances. Meio ambiente, custos e benefícios. São Paulo: Editora Nobel, 1991.

CALTHORPE, Peter e FULTON, William. The regional city: planning for the end of sprawl. Washington: Island Press, 2001

CAMPOS FILHO, Cândido Malta. Cidades brasileiras: seu controle ou caos - o que os cidadãos devem fazer para humanização das cidades no Brasil. 2a ed. São Paulo: Studio Nobel, 1992.

Reinvente seu bairro. $1^{\circ}$ ed. São Paulo: Editora 34, 2003.

CROZIER, M. O fenômeno burocrático. Brasília: Editora Universidade de Brasília, 1963.

CUNHA, Icaro A. (org). Portos no ambiente costeiro. Santos: Editora Universitária Leopoldianum - EDUL, 2004.

FARR, Douglas. Urbanismo sustentável: desenho urbano com a natureza. Porto Alegre: Editora Bookman, 2013

FERNANDES, J.N. A eficácia dos princípios do poluidor-pagador e do usuário pagador. Evocati Revista, $n^{\circ}$ 65, 2011.

FURTADO, Celso. Formação econômica do Brasil. São Paulo: Companhia Editora Nacional, 1971.

GONÇALVES, M. F., BRANDÃO, C. A., GALVÃO, A. C. F. (orgs.). Região e cidades, cidades nas regióes: o desafio urbano-regional. São Paulo: UNESP/ AMPUR, 2003. 
IGLECIAS, Patrícia. Direito ambiental. In: Coleção Elementos do Direito, vol. 15. São Paulo: RT, 2013.

LAMAS, José M. Ressano Garcia. Morfologia urbana e desenho da cidade. Lisboa: Fundação Calouste Gulbenkian, 1992.

LEITE, Carlos e AWAD, Juliana di Cesare Marques. Cidades sustentáveis, cidades inteligentes: desenvolvimento sustentável num planeta urbano. Porto Alegre: Bookman, 2012.

LENCIONI, Sandra. Região e geografia. São Paulo: EDUSP, 2009.

MILARÉ, Édis. Direito do ambiente: doutrina, jurisprudência e glossário. 4 Ed. São Paulo: Revista dos Tribunais, 2005.

MOSTAFAVI, Mohsen e DOHERTY, Gareth (org.). Urbanismo ecológico. São Paulo: Editora GG Brasil, 2014

OLIVEIRA, Francisco de. O estado e o urbano no Brasil. Espaço \& Debates, no 06.

PRADO JUNIOR, Caio Prado. História econômica do Brasil. $4^{\mathrm{a}}$ ed. São Paulo: Brasiliense, 1956.

REIS, Goulart Reis. Imagens de vilas e cidades do Brasil Colonial. Uspiana Brasil 500 anos. São Paulo: Edusp/ Imprensa Oficial SP, 2001.

ROCHEFORT, Michel. Redes e sistemas: ensinando sobre o urbano e a região. São Paulo: Editora Hucitec, 1998.

ROGERS, Ricard. Cidades para um pequeno planeta. Barcelona: Gustavo Gili, 2008.

SANTOS, Milton. Território: globalização e fragmentação. 2. ed. São Paulo: HUCITEC, 1994. Por uma outra globalização: do pensamento único à consciência universal. 5. ed. Rio de Janeiro: Editora Record, 2001. . SILVEIRA, Maria Laura. O Brasil, território e sociedade no início do século XXI. Rio de Janeiro: Editora Record, 2001.

SANTOS, Rosely Ferreira dos. Planejamento ambiental: teoria e prática. São Paulo: Oficina de texto, 2004.

SILVA, Geraldo e COCCO, Giuseppe (Organizadores). Cidades e portos: os espaços da globalização. Coleção Espaço do Desenvolvimento. Rio de Janeiro: DP \& A Editora, 1999.

SIMON, Herbert. As ciências do artificial. Coimbra: Editora Almedina, 1981.

VEIGA, J. E. da. Indicadores socioambientais: evolução e perspectivas. Revista de Economia Política, São Paulo, v.29, n.4 (116), p.421-35, out./dez. 2009a

WALKER, José Roberto. Sala São Paulo: café, ferrovia e a metrópole. São Paulo: Secretaria do Estado da Cultura/ Secretaria do Estado de São Paulo/ Câmara Brasileira do Livro, 2001. 


\section{Teses e palestras}

MACKAY, David. La recuperació del font marítim. Aula Barcelona. Fundació Bosch i Gimpera. Universitat de Barcelona. Barcelona, 2000.

MAGALHĀES, José Francisco Xavier. Espaços náuticos: estruturas de apoio a navegação como possibilidade de requalificação urbana. Dissertação de Mestrado. FAU-USP, 2003.

SALES, Marta Maria Lagreca de. Projeto urbano: opção metodológica e algumas práticas - São

Paulo. Dissertação de Mestrado. Faculdade de Arquitetura e Urbanismo da Universidade de São Paulo, 1999.

\section{Leis e documentos}

Avaliação ambiental estratégica. Brasília: MMA/SQA, 2002. 92p.

AYUNTAMENT DE BARCELONA. Arees de nova centralitat. Barcelona: Regidoria d'Edicions Publicacions, 1987.

BRASIL. Constituição Federal, Capitulo VI - Do Meio Ambiente, 1988. Lei Federal n 6.938, de 31 de agosto de 1981. . Lei Federal n 7.661, de 16 de maio de 1988. . Lei Federal n 4771, de 15 de setembro de 1965. Decreto Federal n 99.274/90, de 06 de junho de 1990. Lei Federal n ${ }^{\circ}$ 10.257, de 10 de julho de 2001.

CONSELHO NACIONAL DO MEIO AMBIENTE. Resolução Conama 001/86, de 23 de janeiro de 1986.

Estudo de Impacto Ambiental - EIA. Unidade de Tratamento de Gás de Caraguatatuba. Abril de 2006.

MINISTÉRIO DA MARINHA - DEPARTAMENTO DE PORTOS E COSTAS. Norma 11/2001, Portaria n52/dpc, Capítulo 1, de 4 de setembro de 2001.

PLAN DE COSTAS. Propuesta de ordenacion de la Zona Costera Metropolitana de Barcelona. Coorporación Metropolitana de Barcelona. Servicio de Publicaciones,1988.

PORTO DERSA - São Sebastiāo. Informaçōes Gerais. Governo do Estado de São Paulo. Imprensa Oficial, 1998.

Programa Nacional de Capacitação de gestores ambientais: licenciamento ambiental. Ministério do Meio Ambiente. Brasília: MMA, 2009.

Região Metropolitana do Vale do Paraíba e Litoral Norte. Emplasa - Governo do Estado de São Paulo, Secretaria de Desenvolvimento Metropolitano. Imprensa Oficial, 2012.

Relatório de Impacto Ambiental - RIMA. Das obras de desmonte de um morro de rocha decomposta na “Gleba D” do TEBAR em São Sebastião, SP. São Paulo: HIDROSERVICE, 1987. 
Relatório Ambiental Preliminar - RAP. Ampliação do Píer Petroleiro Terminal Aquaviário de São Sebastião - Petrobras Transporte S.A. Transpetro. Setembro de 2011.

Relatório de Impacto Ambiental - RIMA. Contorno Norte de Caraguatatuba. Dezembro de 2011. Relatório de Impacto Ambiental - RIMA. Plano Integrado Porto Cidade • PIPC SÃO SEBASTIÂO - SP. Outubro de 2009.

Relatório de Impacto Ambiental - RIMA. Atividade de Produção e Escoamento de Petróleo e Gás

Natural do Polo Pré-sal da Bacia de Santos - Etapa 2. Fevereiro de 2014.

SÃO PAULO. Constituição Estadual. Capitulo IV. 1989. . Lei Estadual n 10.019, de 3 de julho de 1998. Lei Estadual n ${ }^{\circ}$ 997/76, de 31 de maio de 1976. . Decreto Estadual 8468/76, de 8 de setembro de 1976.

SECRETARIA DO MEIO AMBIENTE (SP). Resolução Estadual SMA 41/94, de 16 de dezembro de 1994. . Resolução Estadual SMA 4, de 18 de janeiro de 2002.

SÉRIE DOCUMENTOS. Macrozoneamento do Litoral Norte. Plano de Gerenciamento Costeiro. São Paulo, Secretaria do Meio Ambiente, 1996.

SÉRIE DOCUMENTOS. Macrozoneamento do Litoral Norte. Plano de Gerenciamento Costeiro. São Paulo, Secretaria do Meio Ambiente, 1996.

\section{Sites}

AMARAL, A. C.Z., MIGOTTO, A.E., TURRA, A. and SCHAEFFER-NOVELLI, Y. Araçá: biodiversidade, impactos e ameaças. Biota Neotrop. Jan/Mar 2010 vol. 10, no 1. Disponível em: <http://www.biotaneotropica.org.br/v10n1/pt/abstract?article+bn01210012010 ISSN 16760603>. Acesso em: 14/08/2013.

Biólogos criticam Estudo de Impacto Ambiental do pré-sal. Disponível em: <http://www1.folha. uol.com.br/ambiente/2014/07/1491553-biologos-criticam-estudo-de-impacto-ambiental-do -pre-sal.shtml>. Acesso em: 29/07/2014.

Empresa Tietê Urbano e o Plano Ambiental, Social e Econômico para a Região Urbana do Rio Tietê [PASERRT]. Disponível em: <http://gestaourbana.prefeitura.sp.gov.br/arquivos/arco_tiete/ sumarios/ArcoTiete_Sumario_Magalhaes-Figueroa-ParkCapital-Pomar-JurandirRossi.pdf >. Acesso em: 02/09/2014.

Estudo de Impacto - ampliação do Porto. Disponível em: <http://www.portodesaosebastiao.com. br/pt-br/eia-rima.asp>. Acesso em: 02/03/2012.

Estudo de Impacto - camada pré-sal. Disponível em: <http://www.petrobras.com.br/pt/sociedade -e-meio-ambiente/meio-ambiente/licenciamento-ambiental/>. Acesso em: 30/07/2014.

Estudo de Impacto - duplicação da Tamoios, Contorno Sul e Norte. Disponível em: <http://www. 
dersa.sp.gov.br/>. Acesso em: 21/05/2013.

Lei Orgânica do Município de São Sebastiāo. Disponível em: <http://www.saosebastiao.sp.gov.br/ finaltemp/downloads/LeiOrganicaRevisada1.pdf>. Acesso em: 21/02/2014.

PAC 3S. Disponível em: <http://www1.folha.uol.com.br/poder/2014/08/1495021-dilma-relancapac-com-30-das-grandes-obras-inacabadas.shtml>. Acesso em: 04/08/2014.

Programa Cidades Sustentáveis. Disponível em: <http://www.cidadessustentaveis.org.br/institucional>. Acesso em: 07/02/2014.

SP entrega duplicação do trecho de planalto da Rodovia dos Tamoios. Disponível em: <http:// g1.globo.com/sp/vale-do-paraiba-regiao/noticia/2014/01/sp-entrega-duplicacao-do-trecho-de -planalto-da-rodovia-dos-tamoios.html>. Acesso em: 11/02/2014.

The regional city. Disponível em: <https:/www.nytimes.com/books/first/c/calthorpe-city.html>. Acesso em: 13/02/2014.

Tranus. Disponível em: <http://www.tranus.com>. Acesso em: 12/03/2013.

Unidade de Tratamento de Gás de Caraguatatuba. Disponível em: <http://licenciamento.ibama. gov.br/Dutos/Gasoduto/Unidade\%20de\%20Tratamento\%20de\%20Caraguatatuba/EIA\%20 UTGCA.pdf>. Acesso em: 25/03/2013. 
GLOSSÁRIO

Aglomeração urbana: segundo a lei No 13.089/2015 - Estatuto da Metrópole, é a unidade territorial urbana constituída pelo agrupamento de dois ou mais municípios limítrofes, caracterizada por complementaridade funcional e integração das dinâmicas geográficas, ambientais, políticas e socioeconômicas.

Ancoradouro: área naturalmente abrigada, como baías, enseadas e lagos, próprias para fundear embarcações com âncoras ou poitas.

Amarração: local onde se amarra uma embarcação. Pode ser em boias, píeres, embarcações, cais ou outros locais.

Amplitude de maré: é a diferença da altura entre a maré alta (preamar) e a maré baixa (baixa-maré).

Área de Influência Direta (AID): o estudo de impacto ambiental considera área de influência direta aquela que sofrerá os impactos diretos do empreendimento licenciado, durante as fases de planejamento, implantação e operação

Área de Influência Indireta (AII): o estudo de impacto ambiental considera área de influência indireta aquela que sofrerá os efeitos indiretos da implantação e operação do empreendimento licenciado.

Atracadouro: combinação de um ou mais píeres. Pode estar combinado também com os fingers.

Baixa-maré: nível mínimo dos fluxos das águas nas marés vazantes.

Berço: local determinado no cais onde as embarcações ficam ancoradas em segurança entre cabeços de amarração para operar (embarque e desembarque).

Cabotagem: navegação comercial entre portos do mesmo país (países vizinhos podem ser admitidos também na navegação de cabotagem).

Cais: construção ao longo da margem preparada para a atracação de embarcações.

Calado: distância entre a linha d'água até o ponto mais baixo da quilha de uma embarcação.

Carga de projeto: cargas especiais, com dimensões e peso, que não podem ou cabem dentro dos contêineres. Necessitam de navios especiais ou que contenham equipamentos próprios para o transporte deste tipo de carga.

Contêiner: caixa metálica entre 20 ou 40 pés para transporte de diversas mercadorias, inclusive climatizadas, e com sistema de engate para transporte viário e ferroviário. 
Correntes marítimas: são as direções horizontais tomadas pelas águas do mar em um determinado sentido, principalmente em função dos ventos, da rotação da terra, influência do sol, lua e diferenças de temperatura das águas.

Dársena: escavação efetuada a partir da linha d 'água destinada ao acesso e à proteção das embarcaçōes.

Dique: obras de proteção contra o movimento e ação das águas.

Dragagem: é a operação de escavar o fundo de rios, lagos, represas, mar ou outros locais com água para aumentar a sua profundidade, através de diversas técnicas, como, por exemplo, sucção, garras ou baldes.

Embarcação: qualquer equipamento capaz de se locomover e flutuar sobre as águas, podendo ser embarcações a vela, embarcações a motor, embarcações a remo ou outros tipos de propulsão.

Embarcação de recreio: qualquer embarcação utilizada para o lazer e para o esporte, como pescarias, passeios e competições.

Enrocamento: construção de molhe ou quebra-mar, geralmente utilizando pedras ou blocos de concreto para proteger uma bacia ou um determinado local das forças das águas.

Estaleiro: local para construção, recuperação, consertos e manutenção de embarcações.

Estuário: local onde o rio deságua no mar e sofre as influências das marés.

Estruturas náuticas: conjunto de acessórios organizados no território, junto à água, com acessos por terra e água, planejados para prestar serviços tanto às embarcaçóes e navegaçóes quanto aos usuários.

Segundo o Decreto Estadual no 49.215/04, que dispõe sobre o Zoneamento Ecológico Econômico do Setor do Litoral Norte do Estado de São Paulo, a definição para estruturas náuticas é o conjunto de um ou mais acessórios organizadamente distribuídos por uma área determinada, podendo incluir o corpo d'água a esta adjacente, em parte ou em seu todo, bem como seus acessos por terra ou por água, planejados para prestar serviços de apoio às embarcações e à navegação. Para efeito de classificação, as estruturas náuticas ficam divididas em:

- Estrutura Náutica Classe I: estruturas que não necessitam de aterros, dragagem, rampas, desmonte de pedras, construção de proteção contra ondas e marés. Apresentam, a partir da parte seca sobre as águas, um comprimento máximo total de até $20 \mathrm{~m}$, com até $3 \mathrm{~m}$ de largura, podendo apresentar paralelamente à parte seca uma plataforma de atracação de até $5 \mathrm{~m}$ de comprimento e de até $3 \mathrm{~m}$ de largura, não possuindo construções e edificaçôes conexas na parte seca.

- Estrutura Náutica Classe II: estruturas que não necessitam de aterros, dragagem, podendo apresentar rampas com largura até $3 \mathrm{~m}$, desmonte de pedras, construção de proteção contra ondas e marés. Apresentam a partir da parte seca sobre as águas um comprimento máximo total de até $30 \mathrm{~m}$, com até $3 \mathrm{~m}$ de largura, podendo apresentar paralelamente à parte seca uma plataforma de atracação de até $10 \mathrm{~m}$ de comprimento e de até $3 \mathrm{~m}$ de largura, ficando permitidas construçōes e edificaçôes de no máximo $50 \mathrm{~m}^{2}$ conexas na parte seca, sendo vedadas atividades de manutenção, reparos e abastecimento. Não se incluem nesta classificação as marinas e garagens náuticas de uso comercial.

- Estrutura Náutica Classe III: estruturas que podem apresentar aterros de cabeceira, rampas de até $5 \mathrm{~m}$ de largura, construção de proteção contra ondas e marés. Apresentam a partir da parte 
seca sobre as águas um comprimento máximo total de $50 \mathrm{~m}$, com até $5 \mathrm{~m}$ de largura, podendo apresentar paralelamente à parte seca uma plataforma de atracação de até $20 \mathrm{~m}$ de comprimento e de até $5 \mathrm{~m}$ de largura, ficando permitidas construções e edificações de no máximo $200 \mathrm{~m}^{2}$, conexas na parte seca, assim como as atividades de manutenção e reparos, e vedada a de abastecimento. Incluem-se nesta classificação as marinas e garagens náuticas dentro das dimensões aqui definidas.

- Estrutura Náutica Classe IV: estruturas que podem apresentar aterros de cabeceira, dragagem, construção de proteção contra ondas e marés, rampas de até $10 \mathrm{~m}$ de largura. Apresentam a partir da parte seca sobre as águas um comprimento máximo total de até $100 \mathrm{~m}$, com até 10 $\mathrm{m}$ de largura, podendo apresentar paralelamente à parte seca uma plataforma de atracação de até $50 \mathrm{~m}$ de comprimento e até $10 \mathrm{~m}$ de largura, ficando permitidas construçõos e edificações de no máximo $5.000 \mathrm{~m}^{2}$, conexas na parte seca, sendo permitidas as atividades de manutenção, reparos e abastecimento. Incluem-se nesta classificação as marinas, garagens náuticas e estaleiros dentro das dimensões aqui definidas.

- Estrutura Náutica Classe V: estruturas que podem apresentar aterros de cabeceira, dragagem, construção de proteção contra ondas e marés, rampas com largura superior a $10 \mathrm{~m}$ de largura. Apresentam a partir da parte seca sobre as águas um comprimento acima de $100 \mathrm{~m}$, com mais de $10 \mathrm{~m}$ de largura, podendo apresentar paralelamente à parte seca uma plataforma de atracação de mais de $50 \mathrm{~m}$ de comprimento e mais de $10 \mathrm{~m}$ de largura, ficando permitidas construções e edificaçôes acima de $5.000 \mathrm{~m}^{2}$ conexas na parte seca, sendo permitidas as atividades de manutenção, reparos e abastecimento. Inclui-se nesta classificação as marinas, garagens náuticas e estaleiros dentro das dimensões aqui definidas.

Faixa marítima: faixa que se estende até 12 milhas marítimas da linha de costa, de acordo com a Convenção das Nações Unidas sobre o Direito do Mar.

Faixa terrestre: faixa do continente formada pelos municípios que sofrem influência direta dos fenômenos da zona costeira - municípios em frente ao mar, municípios localizados nas regiões metropolitanas litorâneas ou próximas a estas cidades, municípios próximos ao litoral, dentro de até 50 $\mathrm{km}$ da linha de costa, com atividades ou infraestruturas de grande impacto ambiental sobre a zona costeira ou ecossistemas costeiros e municípios estuarinos-lagunares.

Feeder: porto secundário canalizador e distribuidor de mercadorias das grandes companhias para portos menores.

Fisiografia: descrição dos aspectos físico de uma região.

Fingers: são ramificações fixas ou flutuantes para o acesso às embarcações, conectadas a píeres ou cais, com ou sem terminais de serviços às embarcações.

Flushing time: número de dias necessários para a troca total das águas internas das bacias de uma marina, porto, dársena ou outros locais protegidos.

Função pública de interesse comum: segundo a lei no 13.089/2015 - Estatuto da Metrópole, função pública de interesse comum é a política pública ou ação nela inserida cuja realização por parte de um município, isoladamente, seja inviável ou cause impacto em municípios limítrofes.

Fundear: ancorar uma embarcação. 
Garagem náutica: estrutura para guardar embarcações na água (vagas molhadas) e em terra (vagas secas), podendo incluir serviços de manutenção.

Gestão plena: segundo a lei no 13.089/2015 - Estatuto da Metrópole, gestão plena é a condição de região metropolitana ou de aglomeração urbana que possui:

a) formalização e delimitação mediante lei complementar estadual;

b) estrutura de governança interfederativa própria;

c) plano de desenvolvimento urbano integrado aprovado mediante lei estadual.

Governança interfederativa: segundo a lei no 13.089/2015 - Estatuto da Metrópole, governança interfederativa é o compartilhamento de responsabilidades e ações entre entes da Federação em termos de organização, planejamento e execução de funções públicas de interesse comum.

Granel líquido: carga líquida, como o petróleo, por exemplo, transportada nos porōes das embarcaçōes.

Granel sólido: carga seca, como os minérios, por exemplo, transportada nos porões das embarcaçôes.

Iate clube: estrutura náutica privada composta por uma diretoria e quadro de associados. Pode estar associada a outros empreendimentos, como condomínios imobiliários, áreas sociais e esportivas.

Interface: fronteira comum.

Isobáticas ou isobatrimétricas: são linhas ao longo das quais as profundidades são as mesmas (quando estiverem pontilhadas, as profundidades são aproximadas).

Isobáricas: são linhas ao longo das quais as pressões atmosféricas são a mesma.

Maré: variação do nível do mar para mais (fluxo ou enchente) ou para menos (refluxo ou vazante) em relação a um ponto médio em terra, que acontece todos os dias em função das combinações das forças de gravidade da lua, sol e terra, além da força centrifuga proporcionada pela rotação da terra.

Maré de quadratura: amplitude mínima das marés que ocorrem no período de quarto crescente e quarto minguante da lua.

Maré de sizígia: marés de maior amplitude que ocorrem no período da tarde, quando o sol encontra-se alinhado com a lua.

Marina: é uma estrutura náutica composta por um conjunto de instalações planejadas para atender às necessidades da navegação de recreio, às embarcações e seus usuários e pode estar associada a outros empreendimentos.

Metrópole: segundo a lei no 13.089/2015 - Estatuto da Metrópole, metrópole é o espaço urbano com continuidade territorial que, em razão de sua população e relevância política e socioeconômica, tem influência nacional ou sobre uma região que configure, no mínimo, a área de influência de uma capital regional, conforme os critérios adotados pela Fundação Instituto Brasileiro de Geografia e Estatística - IBGE. 
Milhas náuticas: unidade de medida que equivale a 1.852 metros.

Molhe: construção lançada da terra para o corpo d'água que funciona com o quebra-mar (o mesmo que enrocamento).

Navegação de cabotagem: segundo a Lei no $10.893 / 04$, de 13/07/2004, que dispõe sobre o Adicional ao Frete para a Renovação da Marinha Mercante - AFRMM e o Fundo da Marinha Mercante - FMM, navegação de cabotagem é aquela realizada entre portos brasileiros, utilizando exclusivamente a via marítima e interiores.

Náutico: tudo o que se refere aos assuntos relacionados à navegação.

Nó: medida de velocidade onde 1 milha marítima por hora (1852 metros) corresponde a 10 nós, que equivale a $18,5 \mathrm{~km} / \mathrm{h}$.

Offshore: atividades náuticas afastadas da costa, principalmente relacionadas à exploração petrolíferas em alto mar.

Pé: medida inglesa que equivale a aproximadamente $30,40 \mathrm{~cm}$, ou 12 polegadas.

Píer: construção lançada da terra sobre a água, montada sobre pilotis ou flutuantes, permitindo o acesso às embarcações.

Preamar: nível máximo dos fluxos das águas nas marés cheias ou enchentes.

Porto: local abrigado para embarque e desembarque. Funciona como ancoradouro para diversos tipos de embarcaçōes. Pode ser marítimo, fluvial ou lacustre.

Porto de recreio ou lazer: estrutura náutica localizada em uma área segura e abrigada, composta por um conjunto de instalações com uma série de serviços necessários às embarcações e a seus usuários, associada a outros empreendimentos complementares, que configuram este local como mais uma alternativa de espaço público, ampliando os benefícios sociais e econômicos, principalmente para a comunidade local. Para isto, elas devem oferecer fundamentalmente setores abertos à população, como por exemplo:

- Áreas de lazer e esportivas.

- Áreas e terraços públicos que permitam o acesso ao espelho d'água.

- Local para exposiçóes, eventos, feiras e espaço para convençóes.

- Restaurantes, bares, comércios e estruturas hoteleiras.

- Outros usos de caráter público.

Retroporto ou retroárea: local próximo ao porto para acomodar o excesso ou ampliar as áreas para armazenagem das cargas. Na prática, estas áreas podem estar além do que se considera próximo ao porto. As oportunidades e tarifas mais competitivas para armazenagem podem deslocar os retroportos para outros lugares e até outros municípios.

Rebojo: movimento em círculos das águas (redemoinho).

Trapiche: plataforma, na maioria das vezes em madeira, construída sobre flutuantes ou pilotis que permite conectar a superfície terrestre às embarcações. 
Travel-lift: equipamento de içamento e transporte para guarda ou reparos de embarcações. Este equipamento não permite encostar um barco ao lado do outro.

Porto organizado: segundo a lei 8.630/93, que dispõe sobre o regime jurídico da exploração dos portos organizados e das instalaçôes portuárias, estabelece que porto organizado é o construído e aparelhado para atender às necessidades da navegação e da movimentação e armazenagem de mercadorias, concedido ou explorado pela União, cujo tráfego e operaçôes portuárias estejam sob a jurisdição de uma autoridade portuária. Estabelece também que as áreas de porto organizado são os ancoradouros, docas, cais, pontes, píeres de atracação e acostagem, terrenos, armazéns, edificações e vias de circulação interna, bem como a infraestrutura de proteção e acesso aquaviário ao porto, tais como guias-correntes, quebra-mares, eclusas, canais, bacias de evolução e águas de fundeio que devam ser mantidas pela administração do porto.

Plano Nacional de Gerenciamento Costeiro - PNGC: conjunto de diretrizes gerais aplicáveis nas diferentes esferas de governo e escalas de atuação, orientando a implementação de políticas, planos e programas voltados ao desenvolvimento sustentável da zona costeira.

Plano de Ação Federal da Zona Costeira - PAF: planejamento de ações estratégicas para a integração de políticas públicas incidentes na zona costeira, buscando responsabilidades compartilhadas de atuação.

Plano de Desenvolvimento Urbano Integrado: segundo a lei no 13.089/2015 - Estatuto da Metrópole, é o instrumento que estabelece, com base em processo permanente de planejamento, as diretrizes para o desenvolvimento urbano da região metropolitana ou da aglomeração urbana.

Plano Estadual de Gerenciamento Costeiro - PEGC: implementa a Política Estadual de Gerenciamento Costeiro, define responsabilidades e procedimentos institucionais para a sua execução, tendo como base o PNGC.

Plano Municipal de Gerenciamento Costeiro - PMGC: implementa a Política Municipal de Gerenciamento Costeiro, define responsabilidades e procedimentos institucionais para a sua execução, tendo como base o PNGC e o PEGC, devendo observar, ainda, os demais planos de uso e ocupação territorial ou outros instrumentos de planejamento municipal.

Sistema de Informaçóes do Gerenciamento Costeiro - SIGERCO: componente do Sistema Nacional de Informaçôes sobre Meio Ambiente - SINIMA, que integra informações georreferenciadas sobre a zona costeira.

Sistema de Monitoramento Ambiental da Zona Costeira - SMA: estrutura operacional de coleta contínua de dados e informações para o acompanhamento da dinâmica de uso e ocupação da zona costeira e avaliação das metas de qualidade socioambiental.

Sustentabilidade: segundo José Eli da Veiga, o conceito de sustentabilidade tem suas raízes nas reflexôes de duas disciplinas consideradas científicas, a ecologia e a economia:

Ecologia - conceito de resiliência à capacidade de um sistema enfrentar distúrbios e ainda manter suas funções e estrutura, além da habilidade de absorver choques, se adequar e tirar benefícios, por adaptação e reorganização. Um ecossistema se sustenta se continuar resiliente por maior que seja o aumento do consumo de energia e a poluição produzida.

Economia - apresenta o conceito de sustentabilidade em três diferentes vertentes. As duas primei- 
ras, com ênfase nos estoques, são a sustentabilidade "fraca", onde cada geração legue à seguinte o capital propriamente dito, o capital natural/ecológico e o capital humano/social; e a segunda a sustentabilidade "forte", que destaca a obrigatoriedade de que pelo menos os serviços do "capital natural" sejam mantidos constantes. A terceira vertente rejeita a ênfase nos estoques e tem foco nos fluxos e busca de indicadores de sustentabilidade, necessitando de indicadores mais precisos para mensurar aonde está a verdadeira sustentabilidade de uma determinada atividade responsável por impacto negativo no meio ambiente, como indicadores de "bem-estar econômico sustentável" ou "indicador de progresso genuíno".

Região metropolitana: segundo a lei no 13.089/2015 - Estatuto da Metrópole, região metropolitana é a aglomeração urbana que configura uma metrópole.

Relatório de Qualidade Ambiental da Zona Costeira - RQA-ZC: consolida, periodicamente, os resultados produzidos pelo monitoramento ambiental e avalia a eficiência e eficácia das ações da gestão.

Zoneamento Ecológico Econômico Costeiro - ZEEC: orienta o processo de ordenamento territorial, necessário para a obtenção das condiçóes de sustentabilidade do desenvolvimento da zona costeira, em consonância com as diretrizes do Zoneamento Ecológico Econômico do território nacional como mecanismo de apoio às ações de monitoramento, licenciamento, fiscalização e gestão.

TEU (Twenty-foot Equivalent Units): unidade de medida para calcular a capacidade de um contêiner. Um TEU equivale a um contêiner de 20 pés (comprimento: $6.058 \mathrm{~m}$, largura: $2.438 \mathrm{~m}$, altura: $2.591 \mathrm{~m}$, com capacidade de carga útil de $21.780 \mathrm{~kg}$ ). 
